916.7 W69

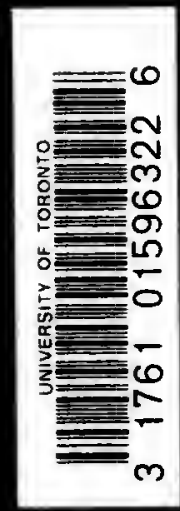




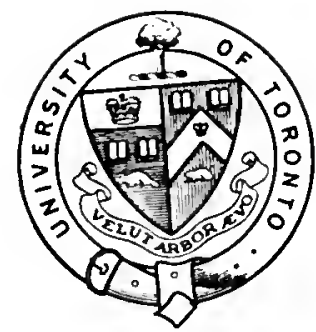

Presented to the

UNIVERSITY OF TORONTO LIBRARY

by the

ONTARIO LEGISLATIVE

LIBRARY

1980 


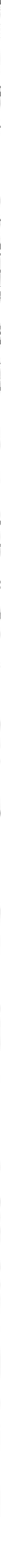




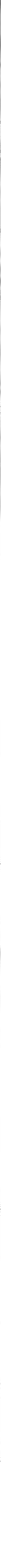




\section{A BRITISH BORDERLAND}

SERVICE AND SPORT IN ERUATORIA 


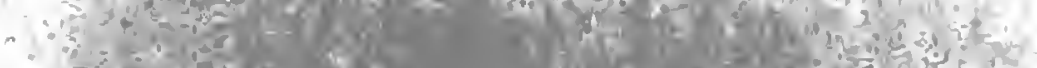

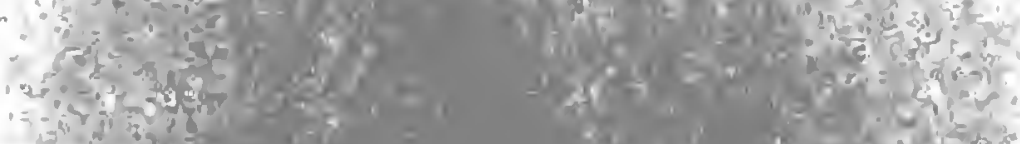

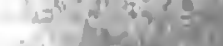

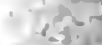

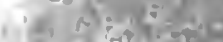

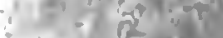

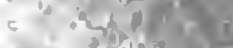
$\rightarrow x_{0}=5$ i⿱ $15=$ $3=48$

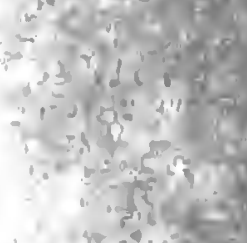
1. $\quad 4 x^{\circ}-2 x=$ $-\therefore \quad 4 x^{2}+3$

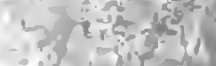
$\because 1$ ie gifle $\because \therefore 3 x^{3}=0$ $x-w^{2}-25$ $\because f^{2}=0$ i. $-3 x^{2}$ $\therefore \rightarrow c^{2}$ tit 10 $=1-10=-50^{\circ}$ $y^{-1}=0 \mathrm{~s}$. $t^{3}+y_{0}$ $x_{10}^{2}=$ 1.1. an

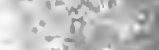
$\cos ^{3} d x$

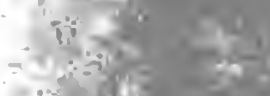
.

$-x_{4} \operatorname{lin}^{2}$ $\frac{32}{3}=$

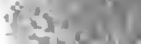
$-x^{2}+y^{2} y$

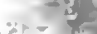
$i=0$ $x=1+2$

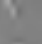

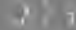
3

$x_{10}$<smiles>[C]1C=C[As]1</smiles>

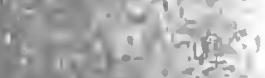

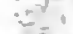
$\therefore=9$ $\therefore 4+4$ - 49 $l^{2}=$ . is

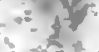

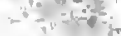<smiles>CCCCC(C)(C)C</smiles>

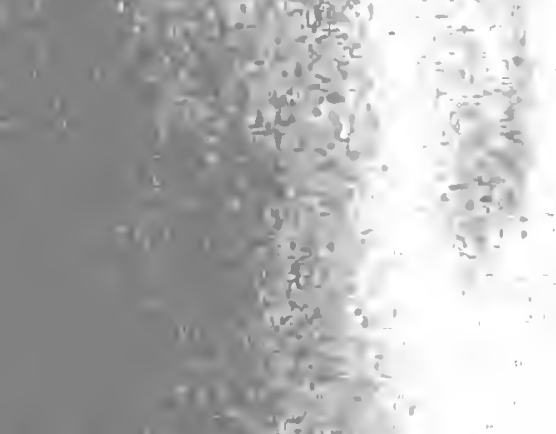

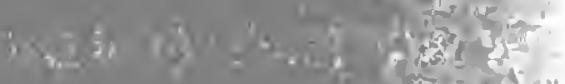

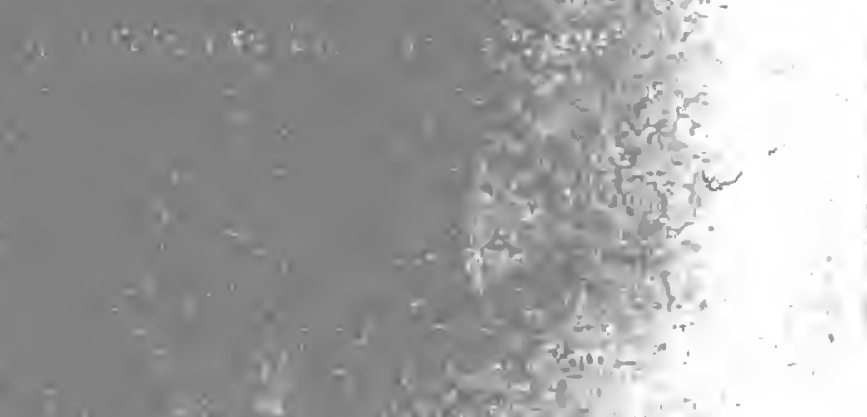

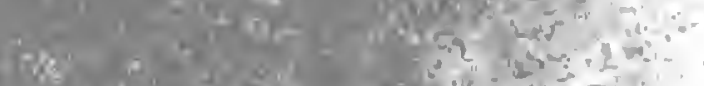

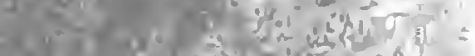

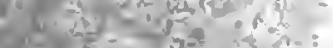

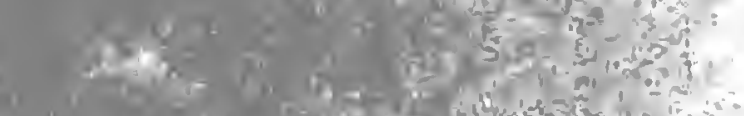

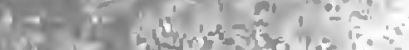

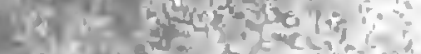

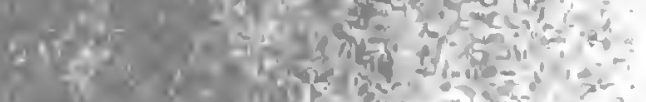

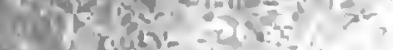

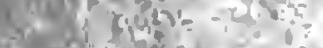




\section{BRITISH BORDERLAND}

SERVICE AND SPORT IN EQUATORIA

\section{BY CAPTAIN H. A. WILSON}

$$
\text { isfueas }
$$

WITH AN INTRODUCTION

BY J. CATHCART IVASON, M.P.

WITH I 8 ILLUSTRATIONS AND A MAP

\section{LONDON}

JOHN MURRAY, ALBEMARLE STREET, W.

1913

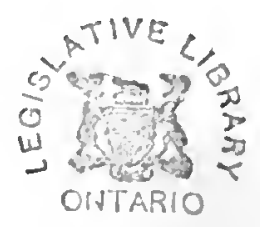




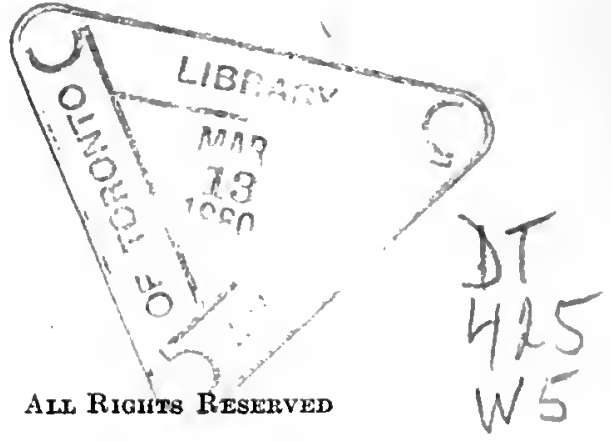


LALLY 
IAND of the low-lying shore that the warm Eastern Ocean caresses,

Shore where the glittering sand offers its breast to the sun:

Shore where the mangrove swanp grey quivers in slow slimy ripples;

Shore of the ship-slaying slioal, hidden and hungry for prey;

Shore that the shipmaster dreads, where the dhows flit like ghosts 'twixt the islands;

Land of the low-lying shore, greeting, aye greeting, to thee.

Land of the wide-spreading plains, where blue distance meets bluer horizon,

Plains of the slow-grazing game, herds without number or end;

Plains where there stalks at his ease the lithe tawny terror, the lion;

Plains where the air, fierce as wine, kindles the brain and the blood ;

Plains where the freedom of space whispers softly of peace unimagined;

Isand of the wide-spreading plains, lomage I lay at thy shrine.

Land of the mountains snow-crowned, rising sheer from the heat-haze bencath them,

Land of the bare sum-cursed rocks, gasping in waterless heat ;

Land of tho lakes and the swamps, where the crocodile basks on the mud-flats;

Land of the rivers and falls, whence old Nile sots his face to the sea;

Land of allurement and blood; land of full plenty and famine; Land that bewitches-and kills, take from me greeting again.

Land wherein Momory dwells, holding our quivering heartstrings,

Yiolding us joy bitter-swcet, pleasure begotten of pain ;

Casting about us her net, intangible, vague, but compelling;

From the fog of our smoke-smothered towns drawing us back to her breast.

Lovers abound at thy feet, sweet wanton, seductive and cruel, Lured by thy pitiless charms, Mistress of masterleas men.

By a moonbeam, a scent, or a tune thou recallest thy lover that leave theo;

Never thou callest in vain, Lorelel land that I love. 


\section{INTRODUCTION}

I HAD the honour once, a good many years ago, of being a fellow-traveller with Bishop Tucker of Uganda, and was intensely interested in both the man and his work, and there and then determined that if ever I could afford the time, I should visit the country.

My opportunity came in 1903, not long after the railway was completed to Port Florence. After a few days in Mombasa, my wife and I took the railway to Port. Florence, and thence by steamer to Entebbe; after a delightful visit there, we returned slowly to the coast, making a short safari to the Ravine, and then staying some little time at Nairobi.

There were but few settlers there at that time, and practically every one was aghast at the offer which had been made to hand over a great stretch of country for the settlement of European Jews. The project was doomed to failure, as the Zionists did not at all approve the project, and common sense revolted at the idea of establishing an imperium in imperio 
viii

amongst native tribes of whom little or nothing was known.

Captain Wilson devotes a chapter of his book to missionary efforts, and indeed it is difficult for any one to write of a country such as Equatoria without doing so.

I think his views, plainly and temperately expressed, leave nothing to be desired. Livingstone stands out above all his fellows-the man who, as a healer and worker, gained the respect and affection of the native races in an unprecedented manner. In their own way no one appreciates a practical Christianity more than the natives, and the watchword that should ever be present in our minds in dealing with natives whom, without reflection, we are apt to describe as ignorant and superstitious, is laborare est orare. A few years later $I$ again had the honour of spending a considerable time in East Africa, as the guest of Sir James Hayes-Sadler, then Governor, and the progress that had bcen made was very striking.

Early settlers in Australia and New Zealand had to make their own way, and the Government of the early days in those countries did little or nothing to promote their interests.

Whatever trouble has risen in Equatoria has rather been the result of the Government endeavouring to do too much, but criticism 
is carping when one considers the vast strides that have been made in every direction during the last ten years.

Industry is making headway everywhere; wool, grain, corn, fibre, coffee, bark, are all very important products of the country. Last year the principal articles of export were :

Grain

Hides and skins

Copra

Rubber

Ivory

$$
\begin{array}{cr} 
& f \\
. & 108,568 \\
. & 73,250 \\
. & 28,055 \\
. & 16,498 \\
& 15,649
\end{array}
$$

The export of live stock has increased in the last twelve months from $£ 5,821$ to $£ 12,588$; coffee from $£ 2,995$ to $£ 5,765$; fibre from $£ 3,725$ to $£ 4,234$. During the last five years the volume of trade from or coming through the Protectorate has increased from $£ 515,052$ to $£ 1,016,898$.

Since our last visit, in 1907 and 1908, the produce of the East African Protectorate has risen from $£ 157,097$ to $£ 333,670$, and the produce of the Uganda Protectorate from $£ 140,277$ to $£ 377,079$. I trust it will not be long before both Protectorates are united under one Governor, with Deputy-Governors for Uganda and the Coast Provinces, as it is 
very confusing, in reckoning the importance of the country, to separate the exports of Uganda from East Africa.

Captain Wilson tells the story of a soldier's life and experience in East Africa, or Equatoria, as he ingeniously names the uplands, in a style which leaves nothing to be desired. He pleasantly touches on the opportunities afforded by the country to travellers and sportsmen and settlers.

The Uganda Railway, which has often been the subject of very unworthy observations, was constructed by our Foreign Office mainly on philanthropic grounds, pressed forward with great force by Sir William Mackinnon, Bishop Tucker, and others, upon Lord Rosebery's Government, and the result and success of the railway must have already far surpassed the wildest dreams of those who urged on the Government its construction.

To leave Mombasa in the early afternoon, and wake up next morning and see herds of game, from giraffe to wart-hog, quite ignoring our existence, is in itself an experience worth all the trouble of a visit to the country.

The country is well provided with the necessary accessories of civilization-hospitals, asylums, gaols.

The railway begins to pay a considerable sum over and above working expenses. Coal 
is talked of. The vast Soda Factory at Lake Magadi will soon be yielding up its inexhaustible treasures, the Government this last year having granted $\mathfrak{1 7 5 , 0 0 0}$ as a first instalment towards the purchase of rolling-stock; the company constructing the branch line from the main line to the Soda Lake.

The fact is undoubted that, in the Upland Provinces in Equatoria, European settlers can make comfortable homes and enjoy good health; but yet there are people very well qualified to judge who do not consider that the peculiar features of the country are likely to prove suitable for children.

"The Rise of our East African Empire," by Sir Frederick Lugard, and "The Uganda Protectorate," by Sir Harry Johnston, are standard works on the country, but, at the same time, a pleasantly written story like Captain Wilson's, full of interest and good sense, is a valuable asset to the literature of the country.

January 17, 1013.

J. Cathcart Wason. 


\section{PREFACE}

MaNY books have been written on Equatorial Africa, still more on big game shooting, and a considerable number on shooting in Equatorial Africa. Indeed, in these days of catholic scribbling the African traveller whose pen is not as ready as his rifle-or even more so-is almost an anomaly.

Badly bitten with this prevalent maladythe ink-erupting epidemic of the twentieth century-I have ventured to add one more volume to the already voluminous literature extant upon my subject.

Not that I would for one moment dignify these pages by arrogating to them any claim to a place in the ranks of literature. They are rather an elaborated diary and a random series of sketches, written originally more for my own amusement than with any view of ultimate publication.

My excuses for rushing into print must be that I spent five years in the countries which I essay to describe, and can claim some knowledge of and a very real affection for a land which in some inexplicable way inspires its xiii 
inhabitants and visitors with a lasting regard for itself, and possesses an extraordinary and compelling fascination equalled by no other which I have visited.

During my service in Africa I had greater opportunities for shooting than fall to the lot of most men similarly placed, and had the good fortune to traverse much unknown country, and to the keen shikári all shooting "gup" is of interest. Further, the country in which I landed in 1902 was vastly different from the East Africa of to-day. The Administration was in its infancy, the Uganda Railway running for a considerable part of its length over temporary line, and the white population, outside official and military circles, practically nil. Some descriptions of these early days may be of interest.

Lastly I have hopes that the experiences related and advice tendered in this book may be of use to sportsmen unaccustomed to African shooting, in which case I shall not have written in vain.

Any criticisms which may be expressed must not be read as in any sense final or authoritative; they are merely an expression of how current events appeared to the mind of a very minor official, who is and was in no sense "behind the scenes." They may be interesting as revealing something of the 
point of view of the class of which I formed a unit.

Parts of Chapters VIII, XIV, XV, XVI, and XXI have previously appeared, in slightly different shape, in The American Field, The Independent (New York), The Field, The Badminton Magazine, and The Empire Reviero respectively, and my thanks are due to the editors of these journals for their permission to make use of them.

My thanks are also due to Captain C. R. Hall and Mr. Young, photographer, Nairobi, for their kind permission to make use of their photographs.

It must be borne in mind that most of the sketches were penned at various times over a period from my arrival in East Africa in the early part of 1902 to my departure at the end of 1906. It should also be remembered that certain episodes herein related, though substantially true, in that every incident described actually occurred, are not the actual history of definite events, but are rather a number of true incidents strung together to make the description of a typical event or period of time, which for good reasons are not themselves actually described. In such cases names have, of course, been altered. Chapters VI and XIII come under this category.

H. A. W. 


\section{CONTENTS}

Introduction by J. Cathcart Wason, M.P. vii Preface . . . . . . . . xiii

CHAPTER I

ZaNzibar AND Mombasa • • . . 1

CHAPTER II

The Uaanda RaIlway-NaIrobi • 11

CHAPTER III

The Uganda Railway - Fort Ternan-

LUMBWA $\quad . \quad$ •

CHAPTER IV

Uganda, Unyoro, and the Nile • 32

CHAPTER V

Nrmule-The Nile Valley-Jinja . . 58 xvii 


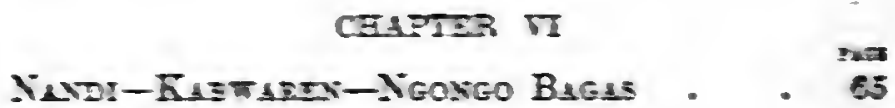

CEAPTES III

CEsSTE TEE LOTA MLSA . . . . 80

CESPTEP TII

I

CISPES II

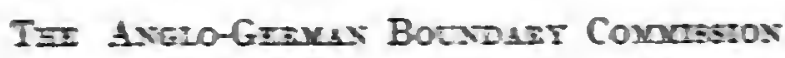

(Combinate) . . . . 109

CEMPIES I

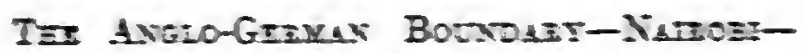

Mosozon: . . - . . . 187

CEAPEER II

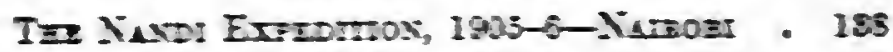

CEIFIES ताI

SEstr . . . . . . . If5

CEAPTER III

A DAr" ToIS . . . . . . 156 
CHAPTER XIV

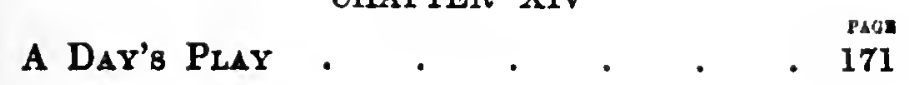

CHAPTER XV

AN Elephant-Shoot • . . . 188

CHAPTER XVI

Leates from aN African GaMe-boOK • 198

CHAPTER XVII

The Ethics of Shikar . . . 218

CHAPTER XVIII

Sports and Pastimes - • • • 224

CHAPTER XIX

"Sketches" . . . . . . . 282

CHAPTER XX

The African Soldier a . . 246

\section{CHAPTER XXI}

Thz MabaI - . . . . 260 
CHAPTER XXII
OAGH

CHAPTER XXIII

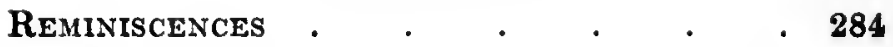

CHAPTER XXIV

Religions and Missions . . . 298

CHAPTER XXV

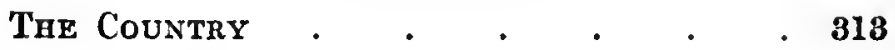

CHAPTER XXVI

The Future $\quad$. $\quad . \quad \ldots \quad$. 321

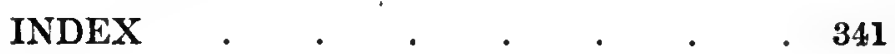




\section{LIST OF ILLUSTRATIONS}

Ronvs of Vasco de Gajia's Fort, Mombasa . - 6

Salisbury Bridoe at Maktpa, jointng Mombasa to The MaINLAND . . . . . . . . 12

Mombasa Harrour: Club in Foreground . . 18

KMINDINI HARBOUR. . . . . . . 30

The Uganda Railway . . . . . . . 54

Shimtino Coolie Camp in the Days of the Railway

Construdtion . . . . . . . . 76

Trophres. . . . . . . . . 104

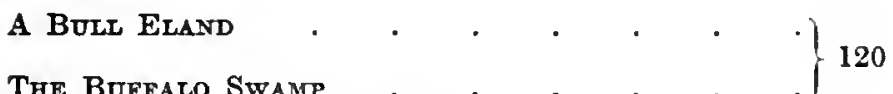

The Buffalo Swamp . . . . . . . . .

The Band, 3Rd Krng's African Rifles • • 170

ELEPHANT $\cdot \cdot \cdot \cdot \cdot \cdot \cdot \cdot{ }_{196}$

Oryx Callotts

Headquarter Companies 3rd King's Africax Rifles on Parade

Typical Scenery round Lake Elmenteita . . 272

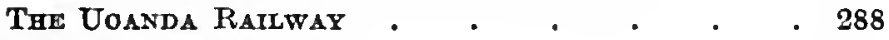

Tame Zerra with Herd of Donkrys . . . 304

On an East african Datry Farm . • . . 320

Tame Erand on East African Farm . . . 330

MaP . . . . . . . . . At the End xxi 



\section{A B R I T I S H BORDERLAND}

\section{CHAPTER I \\ ZANZIBAR AND MOMBASA}

IT was at the commencement of 1902 , while serving in India, that $I$ received a wire offering me an appointment as subaltern in the King's African Rifles. On accepting, I got orders to embark at Bombay in ten days' time for Mombasa. I was away from my regiment on detachment at the time, and the ten days were spent in hurried preparations for my journey and the elaborate precautions which are sometimes unfortunately inseparable from a sudden departure from India. To the uninitiated this may appear ambiguous, but the average subaltern will, I imagine, appreciate my meaning without the necessity of further enlightenment. Enough, that by judicious manœuvring, the gentlemen with blue papers were avoided, and one fine morning $I$, with two other officers on the same mission, found myself on board the S.S. Palitana 
watching Bombay growing beautifully less astern.

The voyage was uneventful, not to say monotonous, and it was with considerable pleasure on my part that I was awakened one morning by the announcement that Zanzibar was reached. Rushing hastily on deck, my eyes were greeted by one of the most beautiful scenes that it has yet been my good fortune to behold.

To the east was a low-lying land lit up with the rays of the newly risen sun. The brilliant, restful green of its luxuriant verdure was a welcome sight to eyes accustomed to the drab grey plains and the crude, gaudy colouring of Upper India. In the foreground, embowered in an emerald setting, nestled the white minarets and houses of the Arab city of Zanzibar, the roofs and pinnacles clean and sharp-cut in the translucent morning air. On the strip of beach in the front of the town lay numberless boats, which, as we watched, kept slipping from the white sand and cut the limpid water as they sped towards us. At the far end of the beach stood a long building, gleaming white in the morning sun. Above it fluttered the Union Jack-the British Consulate. Off shore lay the grey, threatening shapes of half-a-dozen ships-of-war-Italian, German, British-silent and motionless, but 
with that grim quiet which tells of force and power in reserve, dormant and sleeping, but awaiting only a touch to spring into deadly activity and life.

To the west the sparkling sea gleamed deepest sapphire, save where, like milky pearls, the sail of some Arab dhow showed white against the universal blueness of the motherjewel's breast, and the thousand ripples born of the morning breeze shone, iridescent facets, at the kiss of the morning sun. Beyond lay a dark bank of cloud, above which could be seen the darker mountain-tops of the mainland. Then, while we watched, the mists of morning melted apace and showed a dark streak lying along the distant horizon - the shores of Africa. Such was my first glimpse of the Dark Continent, and then and there, in that scene of entrancing loveliness, was born within my breast the first spark of that strange, almost unwilling, love which Africa kindles in the hearts of those that know her.

Half-forgotten memories of childhood surged back into being at the sight of that historic coast. What figures of romance it summoned from oblivion to pass in shadowy procession before the mind's eye-Vasco da Gama, the intrepid Portingal, Burton, Speke, Stanley, Thompson, Seyid Burgash, Tippo Tib : Englishman, Portuguese, Arab-all had fought 
and bled and died upon those distant shores yonder.

Harsh and discordant sounds aroused us from our reverie, and we were aware of many boats filled with skins of every tint from ebony to palest ivory, from which arose a raucous clamour in strange tongues, while the familiar "'Ave a dive! 'Ave a dive!" from swimming urchins recalled us completely to earth and a hearty appetite for breakfast.

At Zanzibar we transhipped, and had a wait of three days before our new boat sailed for Mombasa, our destination. Thanks to the unstinted hospitality of the English colony, those three days-and nights-passed in a whirl of conviviality-and cocktails.

I do not think that I have ever visited any place of which my first impressions were so vivid and so enduring as those which my mind received at Zanzibar. As I picture it now, after a lapse of seven years, it seems to me that, stepping from our boat across the beach, and past the Custom House into the streets of Zanzibar, I walked straight from the twentieth century into the Arabian Nights. The narrow, winding streets, in which all nations of the East seemed to jostle and chaffer, the high old Arab houses, with the blind windows and carved doors, the rows of tiny shops wherein all the wares of the Orient 
lay exposed for sale by their placid, phlegmatic owners-carpets and shawls from Busrah, pearls and opals from Ceylon, silks from China, gold and silver, brass and ivory, ebony and amber, attar of roses and sandal-wood, while over all hung the scent of spices, and on every hand sounded a medley of varying tongues. In the hurrying, kaleidoscopic whirl of passing figures stalked the stately Arab, his sombre garment lightened by golden embroidery and the silver hilt and scabbard of his curved dagger. The dignified, light coloured Turk, the darker Indian, sleek Parsee and oily Bunnia, swaggering Somali and stolid, ebony Nubian, Malay, Javan, Chinese, Persian, and Jap-all were there, while omnipresent in the seething crowd were Swahilis, ranging in tint from the coal-black Bantu negroid to the yellow Arab type; the men, brawny, bulky savages whose ugly faces wore an ever-present grin, and the women making brilliant splashes of colour in the sunlit street in their brilliant "lesus," and whose studded ears and elaborate coiffures were things of wonder.

It was the first time that I had ever beheld anything so typically Eastern. It was what my earliest imagination had pictured as a street in Baghdad or Cairo in the days of Haroun-el-Raschid. I glanced around me, half involuntarily, expecting to see the 
calenders or the Barmecide coming towards me.

All of the East that I had so far seen had been modernized into an Occidental parody of itself. The India of to-day is a heterogeneous jumble of East and West. An ash-smeared faquir in an electric tram-car, Parsees in motors, electric lamps lighting up a burning ghat-such are a few of the bizarre incongruities of this twentieth-century India.

Our three days' stay in Zanzibar, gilded with the wondrous glamour of the Orient, passed all too quickly for me, gripped as I was by their subtle charm, and it was with keen regret that I bade farewell to my newly found Baghdad and embarked one night for Mombasa, our destination.

Arrived the next morning, we found ourselves anchored in Mombasa harbour, opposite the Custom House, with the usual vociferous medley of dusky boatmen swarming round our ship, and realized that our sea journey was at an end, and that the Dark Continent was before us.

Few places have so stirring a history as the island which lay before us, for the town of Mombasa is situated on an island set in a land-locked bay. Its native name, Mvita, signifies "War," and thoroughly has it earned its grim sobriquet. Negroes, Arabs, Portuguese, 


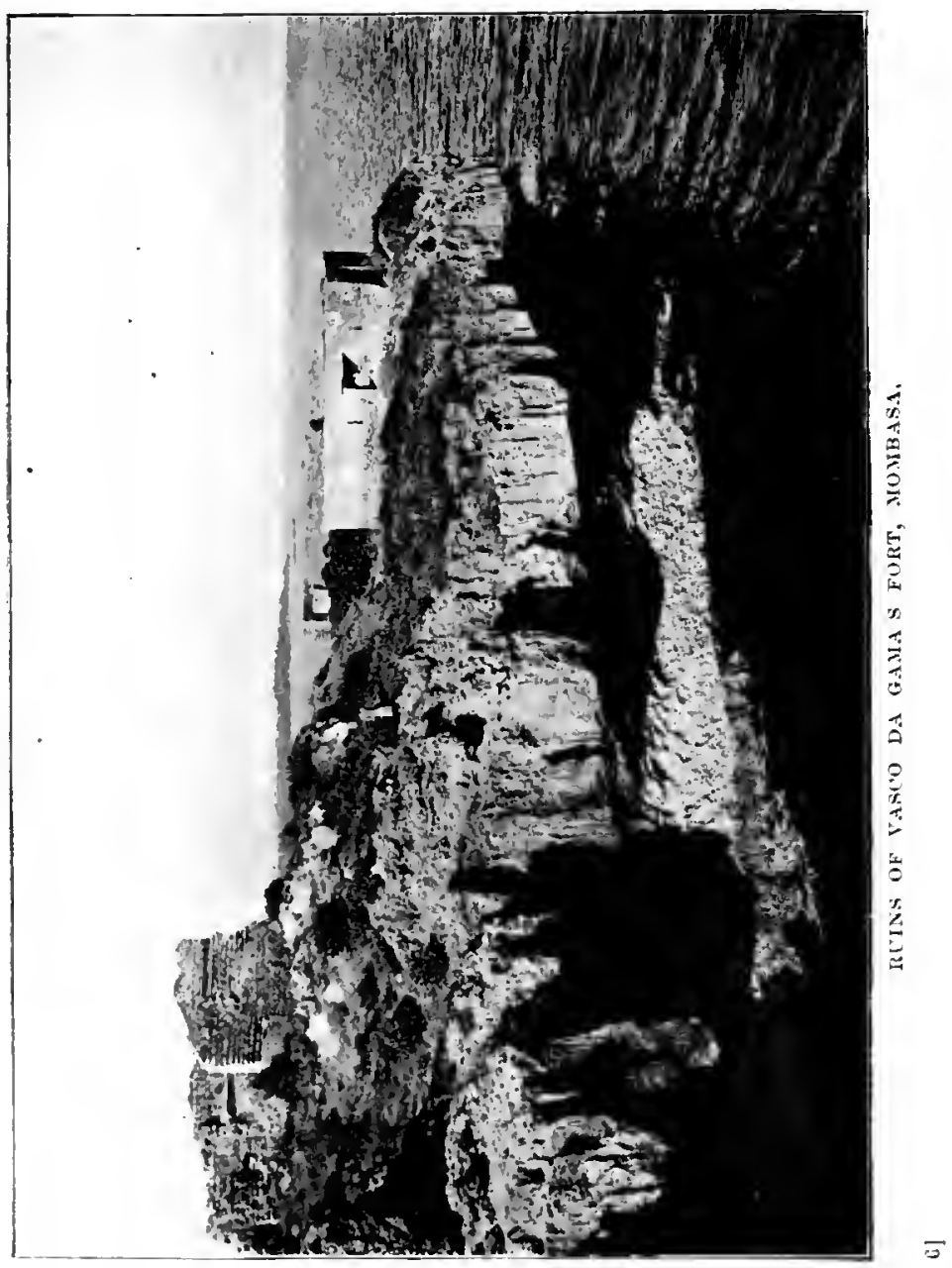


$+1$ 
and Englishmen have fought and died there. Indeed, its history is one long record of battle and siege. First captured by the conquering Arabs from its native rulers, there followed a period of warfare between its new masters and the early Portuguese seamen, the town and fort being alternately besieged and captured by either party, finally falling for good and all to the Arab Sultan of Muscat and Zanzibar, from whom it is now held by Great Britain, together'with the ten-mile strip of coast-land from Somaliland to German East Africa, on a lease perpetually renewable at England's option.

The town, like Zanzibar, is Arab, while the island is dotted with a sprinkling of modern bungalows of the English officials and traders, and the fort at the harbour's mouth is a relic of Portuguese occupation. Though not so polyglot as Zanzibar, Mombasa is full of interest, chiefly on account of its association with Vasco da Gama, the ruins of whose fort and whose navigation-pillars still stand.

Our first feeling on landing was a violent curiosity as to our future destinations-at least I know that mine was-for our orders had only told us to report at Mombasa. The future was a blank. This feeling entirely crushed any desire for investigating the place and seeing the local sights. However, our 
curiosity was not yet to be gratified, and it was not until a couple of days had passed that, after the receipt and despatch of many telegrams, we discovered that one of us was to remain in Mombasa, while the other two, of whom I was one, were to proceed to Uganda.

Then commenced a round of shopping. We had both left India at short notice, which, together with our ignorance of our destination beyond Mombasa, had prevented the layingin of stores. Consequently what we needed had to be bought under expert local advice in Mombasa-at Mombasa prices. This completed, we had leisure to look about us.

One of the first things that strike the visitor to Mombasa are the trolleys, whose lines with their points, etc., traverse every street. A relic of the commencement of the Uganda Railway, the trolley is the only means of locomotion. Every resident has his own private trolley-smartly painted or varnished, with polished brass-work, and two uniformed trollcy boys who rattle their "bwana" along at a rare rate with the invariable cheery grin, which is the unfailing equipment of the coastboy. Horses do not do well in Mombasa, and I don't think that any one keeps them now. Hence the trolley, which I hope to see superseded in the course of time by the rickshaw. The climate of Mombasa is similar to that 
of Zanzibar, but somewhat cooler, and in that haven of refuge, the club verandah, overlooking the harbour, there is nearly always a seabreeze to be felt.

The population of the island is, I believe, about 28,000, a large proportion of which are agriculturists. In their "shambas" or gardens are raised pineapples, pomegranates, coco-nuts, dates, tobacco, bananas, citrons, and many other fruits and vegetables. So fertile is the soil that very little cultivation is needed, and a very large part of the population lives entirely on the produce of their "shambas." At that time Mombasa was the headquarters of the Protectorate Administration, which has been since removed to Nairobi.

On the whole there are pleasanter places in which to live than Mombasa. Though quite healthy, it is humid and unpleasant. Insect life is too plentiful for one's absolute comfort -and mosquitoes flourish and thrive.

We had come to Africa prepared to rough it to the last degree, and I think that we were disagreeably disappointed to find ourselves in a flourishing town, with shops, hotels, local newspapers, and a club. Altogether it was too civilized for us. There were European ladies to be seen reading Reuter's telegrams in the club, and evening dress and stiff collars were a matter of daily occurrence, and not a thing to 
be dreamed of as a memory of the past and an anticipation of the future, as they are upcountry.

"No," we agree, "this is altogether too civilized;" and it is with an undisguised feeling of gladness that we set our faces towards Uganda, or rather take our seats in the midday train for Nairobi, and find ourselves travelling towards the heart of Africa on the Uganda Railway. 


\section{CHAPTER II}

THE UGANDA RAILWAY-NAIROBI

Leaving Mombasa, the train passes through the big railway yard and workshops at Kilindini, once railway headquarters, crosses the Salisbury Bridge at Makupa, and we are at last on the African mainland.

At first the country is densely covered with luxuriant tropical vegetation-bananas, mangoes, palms, and baobabs-with huts and cultivation everywhere. Here and there small hills show above the tops of the bush verdure. After a while it changes-the earth becomes drier, less green. A thorny scrub of mimosa replaces the luxuriant greenery. Stretches of open plain appear, with isolated hills and small ranges here and there. We have left the cultivated, fertile coast-belt. On the hills grass is - non-existent, not a patch of green breaks their stern, drab uniformity. They rise sheer and sudden from the plains, steep and rugged, craggy and forbidding. The grey and black basaltic lava rocks show clearly their volcanic origin. Far away in the west 
we see the snow-crowned peak of Kilimanjaro, the highest mountain of Africa. High above a dark cloud-bank shows the virgin snow, and through the clear upland atmosphere it seems to hang suspended in mid-air, tinted with the roseate rays of the setting sun.

We are in the arid, waterless Taru Desert by now, that dried-up land which was a name of ill omen to all the caravans in pre-railway days. Our carriage is inches deep in the allpervading red dust of the desert. Since leaving Mombasa we have come steadily upwards, and as the sun falls to rest we still are rising. Presently the train stops. We have arrived at Voi station, and dinner. In the diningroom we discover a hapless German, ignorant of all tongues save his own, who is making his way on foot to Moshi, the German station on Kilimanjaro. One of our party who has the gift of tongues does a little interpreting for him, with the result of getting him accommodation for the night. As the train steams out we see him haranguing in guttural polysyllables the bewildered Hindu station-master. I have often wondered as to his subsequent fate.

We awoke early next morning, to find the atmosphere sensibly cooler, and a glance from our window shows that we have passed into yet another region. Over vast, open downlands the train winds its way, great rolling 


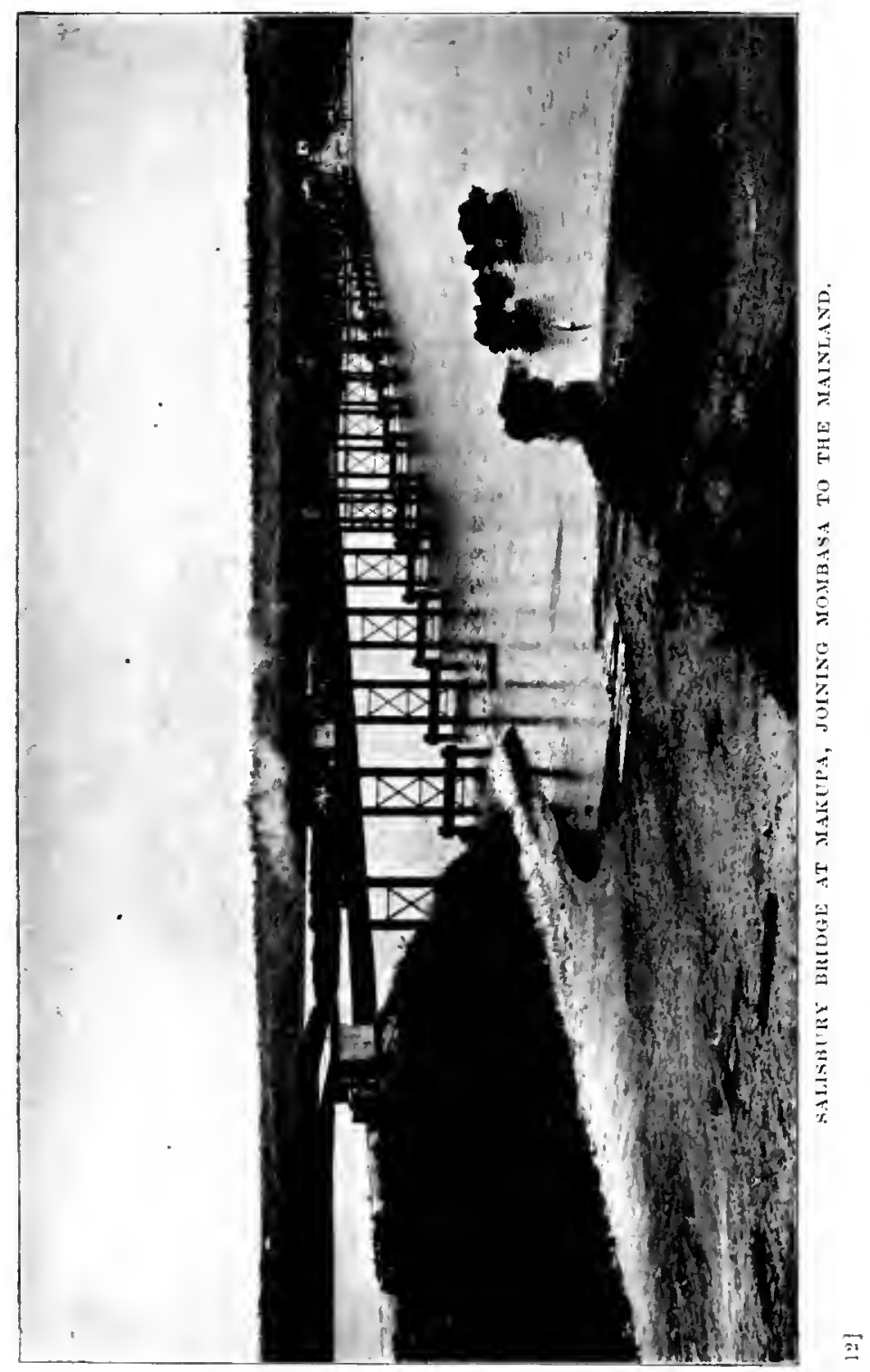



expanses of grass-land on every side. But we have no leisure to study the country. That one glance had shown us its inhabitants, and we held our breath in astonishment. We had heard much during our short stay in Mombasa of the game of the uplands, most of which we had received with the proverbial grain of salt. Now that the game was before our eyes, it was plain to see that our informants had erred on the side of moderation. To the number of animals there seemed no limit. One had not imagined that so much wild life existed in the world-still less in our small corner of it.

On our left-westwards - the country is a game-reserve, in which no shooting may be done, the railway marking its limit, but the game is almost as plentiful on the other side of the line as it is within the reserve. Great herds of Grant's and Thompson's gazelles, zebra, wildebeeste, and everywhere the dull red hartebeeste, commonest of African antelopes. But it is the quantity rather than the variety which holds us in astonishment. Mile after mile the country is thick with the grazing herds-there must be millions of animals; it is a thing of which it is impossible to have any conception, and even seeing it for the first time one feels inclined to doubt the evidence of one's eyes, and to set down the whole vision as a dream. 
And the wonderful tameness of them all! They mind the puffing engine and its crowded carriages not one whit. Here and there a young buck darts off as we draw near, with a great show of fright, bounding along, stopping every now and then, and again flinging up frolicsome heels as he leaps away; but the rest of the herd watch us stolidly, if indeed they trouble to raise their heads at all, occasionally glancing at the youngster with such a look of indulgent amusement that we began to feel that after all his alarm is in no way real-merely assumed and put on for the deception of his enemy, man-and that in truth it is only because he is under the spell of this glorious country, which has fired his young blood, that he has moved at all. Afraid! Not he.

But let the train stop, or let a man appear upon the plain. Do they stand at fifty yards and watch? Not they. An instant stampede, and when they have placed about three hundred yards of grassy veldt between themselves and you (you being the walking man) they begin to think of stopping to consider matters. No, the fact is that they know too much, these fearless animals; and at the end of a hard day, after many unsuccessful stalks on these coverless plains, the lord of creation, wrathful and perspiring, realizes that the 
simple antelope is neither so simple nor so fearless as he once thought him. It probably will not soothe his ruffled temper to cross the line into the reserve and find that the herds will come within twenty yards or so of him and pursue a parallel course, observing him minutely the while, with almost indecent curiosity. They know just as well as he does that he may not shoot there.

The train clatters over a girder bridge spanning a small nullah, and amongst the feathery tops of a mimosa grove in the bed of the streamlet we catch a glimpse of black and white blotches, long swaying necks, and small pointed heads nibbling the young shoots. A herd of giraffe feeding. Then amidst the grazing herds we see a bevy of ostriches scuttling madly over the ground, which they cover at a tremendous pace. The wariest, cunningest, and hardest beast to stalk in Africa.

Presently we stop at a tiny station; a couple of tin houses, some mud huts, and a few ragged tents, with the usual motley crowd of heterogeneous loafers that a railway station seems to attract in all lands. While the engine takes in water the Indian station-master shows us the pug-marks of a lion who carried off a goat from here last night. We follow up the tracks until we lose them on hard, dry ground, and 
then go back to find the train waiting for us in order to start.

It has gone a short way when a black, bulky, and ungainly mass is descried in the scanty shade of a stunted acacia. Our first sight of rhino-outside the Zoo-and very sleepy and plethoric he looks as he takes his ease. Subsequent experience will teach us that, ungainly as he seems, he possesses extraordinary mobility. "Like a motor-car running amuck," I have heard him described.

Presently a fellow-passenger, an old and tried shikári, points out to us a celebrated swamp which is said always to harbour at least one lion and where many have been shot, and suddenly we actually see one-not nearly as royal as we imagine he should look, as he slinks out, and then, turning, slinks back again into the dense mass of reeds. Possibly the raider of last night.

Then gradually the game begins to thin down, and at last disappears entirely; mud huts, tents, and tin houses rise from the plain, and we are steaming into Nairobi, the headquarters of the Uganda Railway, having done. the 250 odd miles from Mombasa in just over twenty-three hours.

We spent two days at Nairobi, staying at the mess of the 3rd King's African Rifles, whose headquarters are here. The Nairobi 
of 1902 was a very different place from the Nairobi of to-day. Roads were conspicuous by their absence, and, save for the railway employees' houses on the plain and a few officials' bungalows on the hill, there were not many signs of human habitation. We drove across the plain, innocent of roads, to the hill on which stood the military lines, since shifted to another location. Nairobi, when I last saw it at the end of 1906, was hard to recognize as the same place as it was on my first introduction to it. Then a few houses scattered broadcast on the open veldt, it was without form and void. Thanks in a great measure to the unceasing labours of the Sub-Commissioner-Mr. John Ainsworth, C.M.G.-out of chaos has sprung a handsome, picturesque, flourishing town, whose well-kept roads, bordered with avenues of blue gums, are the pride of the Town Council. Imagine a Town Council in 1902.

Its advantages over Mombasa as the seat of Government are manifold. The climate, resembling that of the Riviera, is extremely healthy, and the large civil population, for the surrounding country is thickly settled, is in much closer touch with the Government-to mention but two.

To me one of the chief attractions of the place is that horses do well here. Though 
visited by that terrible scourge horse-sickness, on the whole horses thrive, and the East African country-breds show great promise. Now that the railway crosses the "fly-belt" near the coast, imported horses can be brought up in comparative security in their closed boxes, and at the Nairobi races, in consequence, some very good animals are pulled out.

Here we caught our first glimpse of the renowned Masai, whose name was at one time the terror of Eastern Africa.

Much of their ancient glory has departed, but they are still a fine fighting race.

Our stay at Nairobi was, much to our regret, limited to two days, and we had to catch the weekly train which ran between Nairobi and Port Florence on Lake Victoria, and so, after an all-too-brief stay, we once more embarked on the Uganda.Railway for our destination, Fort Ternan. 


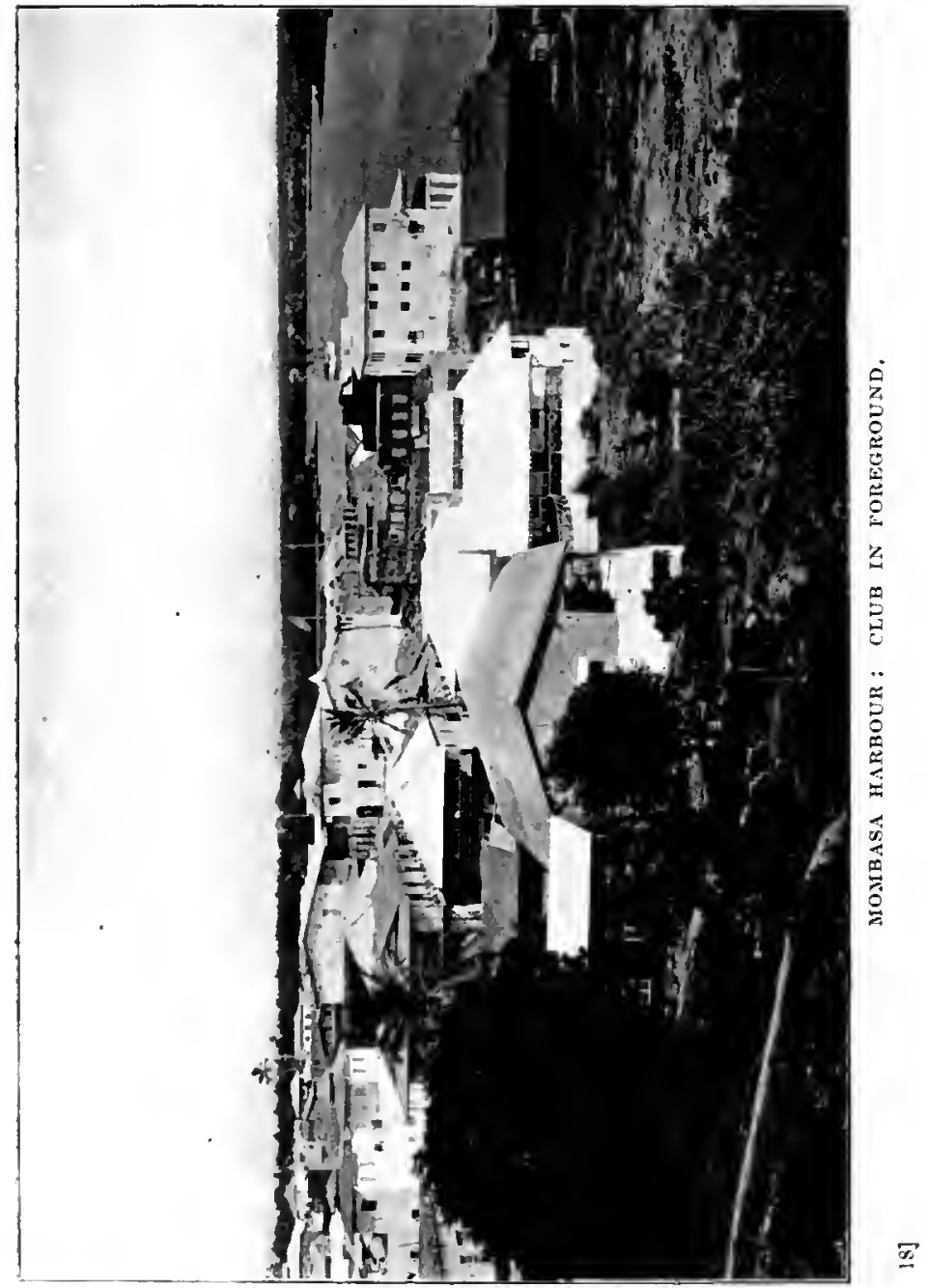





\section{CHAPTER III}

THE UGANDA RAILWAY-FORT TERNAN

一LUMBWA

IN those days the railway was in its infancy, and the discomforts of travelling were numerous and varied.

My travelling companion, Captain Ward, and I leftNairobi, taking with us sufficient provisions for lunch that day, since in our innocence we expected to find numerous dâk bungalows and refreshment-rooms, as between Mombasa and Nairobi.

The journey opened auspiciously. A glorious day, magnificent scenery, and the thousand and one sights of vivid interest to new-comers made the time pass all too quickly. We lunched well, and after lunch the scenery again occupied us. When scenery palled we settled down to picquet, after hearing from a railway official that there was no station where tea could be obtained, but that dinner was to be had at Nakuru, where we were due at 7.20. Our picquet was finally interrupted by 
the fall of darkness, and we sat in the gloom and thought of Nakuru.

Presently the train stopped, but it was not Nakuru: it was some small wayside station. The guard told us that we should be a little late at Nakuru, which didn't cheer us up. We asked him to get the carriage lamp lit. He replied that it was no use lighting it, as it was bound to go out. We insisted, and he lit it-grumbling. In two minutes it was out. We made him relight it. This time it expired in something under a minute, and the guard flatly declined to have anything further to do with it. "What's the good of lighting it," he said, "when it goes out at once?" What indeed? Eventually we got light-of sorts-by buying from the Indian station-master an inferior hurricane-lamp. $\mathrm{He}$ charged us exactly five times its bazaar price, but he had us in a cleft stick-it was either that or darkness, so we paid and called him names-after we got the lamp.

After leaving that station many things began to happen. The train stopped. We looked out, but no Nakuru, no station of any sort; nothing except darkness. It transpired on inquiry that something had gone wrong with the engine. This, however, was eventually repaired, and we moved slowly-very slowlyforward, only to stop again very shortly. 
After that we stopped about once every ten minutes, sometimes for a quarter of an hour, sometimes for two hours, seldom for less than half an hour. At about ten o'clock, during one of our numerous halts (at a station this time), we learnt from a fellow-passenger that there was a train derailed in front of us, and that in consequence we probably should not reach Nakuru till the morrow-if then : it all depended upon how long it took to get the derailed one fixed up. This same kindly individual, whom I shall never cease to bless, took pity on our starving condition, and gave us from his ample food-supply (he was a railway official and knew the game), a tinned tongue and some mixed biscuits, off which we dined. We then turned in and slept, the train being still at a standstill. We awoke next morning at seven o'clock. It was very cold, and raining fitfully. The train was still standing, but not in the same station as when we had fallen asleep. We were now in a vast, open plain, with here and there patches of wocded, parklike country. One could see far in every direction over the rolling uplands, across which wound the railroad. No human habitation was in sight. Far away in the distance a few hartebeeste were feeding, the only sign of life in the entire prospect.

With spirits falling even lower we hurriedly 
dressed and got outside, to be told that the engine had once more broken down. We inquired for Nakuru, and found that we had passed through at about five o'clock that morning. We also learnt that there was no other dâk bungalow nearer than Port Florence, the railway terminus on Lake Victoria Nyanza.

To cut short the harrowing tale. Owing to various causes-breakdowns, wash-outs, and derailments-we reached Fort Ternan some twenty hours late, after living on our fellowpassengers for two days. I well remember, during one of our numerous stoppages, lighting a fire by the side of the track and cooking an "Army Ration" which some charitable stranger had contributed towards our upkeep-and very good it was too.

When, late on the following evening, we arrived at Fort Ternan, all discomforts were quickly forgotten, for we learnt that a party of Lumbwa tribesmen had attacked a camp of Punjabi railway coolies during the previous night, killing and wounding several. Opinion in general tended towards the prospect of a punitive expedition-in local parlance "a show" - as both the Lumbwa and their fellowtribesmen the Nandi had recently been giving a considerable amount of trouble. On the night of our arrival, Ward and I were installed in the only vacant house in the station. Here 
in England the building would hardly be dignified by the name of house, and any one compelled to live in it would probably consider himself hardly used, but we found it very comfortable once we had got our kit moved into it. As I spent a good deal of my time in Uganda in houses of this type-which were then about the only houses known--perhaps a brief description of my first residence might prove interesting.

The roof, which was of grass, was well thatched and quite waterproof, the walls were of wattle and daub, about three inches in thickness; they were plastered inside and out with cowdung, and whitewashed when dry with whitewash made from a kind of chalk obtained locally-which also served the purposes of pipeclay for cleaning the equipment of the troops. The floor was of beaten clay, also plastered with cow-dung, to keep down the jiggers-of which more anon. Windows, innocent of course of glass, were cut in the walls and were closed at night with wooden shutters manufactured from "chop boxes," etc. Both bed and living rooms were circular, about twelve feet in diameter, while the small room between was used as a kind of pantry or storeroom, and was fitted occasionally with doors of a similar manufacture to the shutters. The illustration at the end of this chapter will 
give a fuller idea of the house (which was in fact two native huts joined by a third small room) than will any amount of description.

The highest point of the rooms was fifteen or sixteen feet in height, while the store-room was seven or eight feet. Taken in all, these houses were, if not luxurious, quite waterproof and comfortable. In these days practically every Protectorate official rejoices in a stone or corrugated-iron house, but in 1902 such were few and far between, especially in Uganda.

Every building in Fort Ternan had been constructed by the troops with the aid of such few tools as wcre supplied by the Government. In those days money was too scarce for lavish expenditure on buildings, and the whole of the military lines at Fort Ternan, and indeed most other stations, had been erected by unskilled labour, from materials locally obtained. Such stations wcre entirely constructed by the troops and military-transport porters under supervision of their white officers, and had sprung up without a single penny of expenditure, either in labour or material, save what an officer cared to purchase for his own house out of his own pocket.

The days succeeding our arrival were filled with rumours of war. We were followed from Nairobi by four companies of the 3rd K.A.R., shipped off at a couple of hours' notice. 
Our permanent garrison at Fort Ternan consisted of a double company of Sikhs and two companies of African troops of the 4th K.A.R., while at Mohoroni, some sixteen miles up the railway line in the direction of the lake, was another double company of Indians. With this force we picqueted some seventy miles of railway, and placed all the stations in a state of defence, for a favourite amusement of the local savages was to cut up the coolie gangs working on the railway, to say nothing of looting fish-plates, bolts, nuts, etc., to be worked into spear-heads. The Deputy Commissioner of the Protectorate arrived, and a summons was sent out to all the big Nandi and Lumbwa chiefs to come in for a "shauri" or conference. This summons was disregarded by several, and things were looking promising from a military point of view, when a cable was received from the Foreign Office, who then administered the country, definitely negativing any punitive expeditions.

To compromise matters, a fine of cattle was imposed on the offending sections, and it was determined to establish a post in the Lumbwa country, which had hitherto been very little explored by white men.

A slight geographical summary of the district is perhaps necessary. At its 525th mile the Uganda Railway, descending from the Mau 
Plateau, drops into the Nyando Valley, so called from the Nyando River. The railway follows this valley, which is, as it were, a gap cleft between two hilly tablelands, that to the south being inhabited by the Lumbwa and that to the north by their kindred tribe, the Nandi. Fort Ternan is situated towards the head of this valley, which, as it nears Lake Victoria, broadens out into the flat, thickly populated Kavirondo Plain, the population of which are Kavirondo, a Nilotic race of agriculturists. At the time of which I write, we had a post at Nandi, and that country, owing to various punitive expeditions and to the fact that the old earavan road to Uganda traversed its northern edge, was better known than Lumbwa, into whieh very few Europeans had penetrated.

On the decision to establish a post in Lumbwa Major (now Colonel) E. H. Gorges, D.S.O., was placed in charge of the country, and a site for the station having been determined on, I accompanied him with my company of African troops to garrison Kericho, as the post was named. It lay some seventeen miles distant from Fort Ternan by a very hilly and precipitous track, and once arrived there, the energies of the three Europeans, Colonel Gorges, myself, and my British sergeant-instructor, were pretty fully occupied. There was of course a 
tremendous amount of building to be done, in addition to which friendly relations with the Lumbwa had to be established, and finally my company, largely composed of recruits, nceded a considerable amount of polishing "on the square." Notwithstanding the reported hostility of the "Laibon" or chief medicine man of the tribe, the Lumbwa rapidly became most friendly, and the market which we opened was daily thronged by the surrounding natives, bringing in grain, vegetables, and a certain amount of live stock for sale.

As the harvest that year had been a heavy one, and any amount of grain was daily brought in for sale, wc decided to lay in a stock as rations for the troops. The grain, a species of millet, was purchased with "trade goods" consisting of coarse calico, beads, iron and brass wirc, salt, etc. Money had practically no value, and very few of the Lumbwa would accept it.

After about a month of hard work things were getting somewhat shipshape, when one of the chiefs, by name Aragobeliage, living some nine miles from Kericho, commenced to give troublc, and to intcrfere with parties on the road to and from Fort Ternan. Accordingly Colonel Gorges determined to bring him to reason, and I had my first experience of an African "show"-though in a very mild way. 
At three a.m. on a cold, rainy morning, I had a surprise parade of my company, and, selecting fifty of the old soldiers, we left the "boma" under the guidance of a fricndly Lumbwa, making by a circuitous route for the abode of the recalcitrant Aragobeliage. It was pitch-dark, very cold, and raining, and we had to cross three breast-high streams on our way, but notwithstanding the general discomfort, I was treading on air. It was my first independent command, and it wasn't going to be my fault if it wasn't a success. Probably Aragobeliage would show fight. He had the reputation of being a truculent old person. Surely he would resist. And then rose visions of the first action in a Lumbwa campaign, medals, brevets, D.S.O.s, and the rest.

As we stumbled in single file along the winding native track, the east gradually lighted up with the false dawn. We pressed forward, aided by the growing light, anxiously watching the faint pink glow which heralded the dawn of day. Then, as day broke, and objects began to loom vaguely through the morning mist, we halted. In a few moments our surroundings became distinctly visible, and we found ourselves within a hundred yards of the chief's kraal, with the scattered huts of his followers on all sides. Our night march had been a complete success. Despatching 
my black colour-sergeant with half my party to "round up" an imposing-looking cluster of huts near by, I with the remainder surrounded the chief's kraal. In a quarter of an hour we had made a clean sweep of everything, unfortunately-from my point of view-without a shot being fired. The two parties united, and we found that Aragobeliage was not one of the prisoners. Inquiries amongst the captured elicited the fact that the chief had left the night before to visit the Laibon, and that he had ordered all his wives and cattle to follow that morning, thus proving that something was up. However, he was a bit late, for his entire domestic establishment, as well as his flocks and herds, were now in my hands.

While this colloquy was taking place, the alarm spread rapidly over the countryside, and at the end of it $I$ found that all the hills around were covered with warriors, whose attitude seemed decidedly threatening. Whistles and war-horns were sounding, and as I was outnumbered by about seven to one, with fresh warriors constantly arriving from all points, I decided to make for Kericho with my booty.

I had proceeded some little way when I noticed that the "elmoran," or warriors, were becoming more truculent in demeanour, and approaching closer. However, as I had no intention of commencing hostilities, I told 
my interpreter to proclaim that Aragobeliage was being punished for disobedience of the orders of the Government. This he did, but it made no apparent difference in the attitude of the natives, and I suddenly espied a strong body of warriors, the sunlight gleaming on their big spears, detach themselves from the main body and move off at their loping trot round a hill, making for a pateh of thick scrub, which was the worst bit of country I should have to traverse on my way back.

"Ha! ha!" I chuckled to myself, "an ambush! I shall have a scrap after all, without firing the first shot" (which my orders forbade me to do). My disgust may be imagined when a tremendous shouting arose, the ambuscade suddenly reappeared, and round the hill above me there marched into view my sergeant-instructor with fifty rifles and a Maxim. He had come out to support me in case of trouble, and all chance of a scrap was gone. A hundred rifles and a Maxim were too strong a party for the Lumbwa to take on in cold blood, I greatly feared. And so indeed it proved, for although the warriors hung about our flanks and made wordy demonstrations from various hill-tops, they stopped short there, and we arrived back at Kericho about midday, remarkably hungry but not otherwise troubled. 


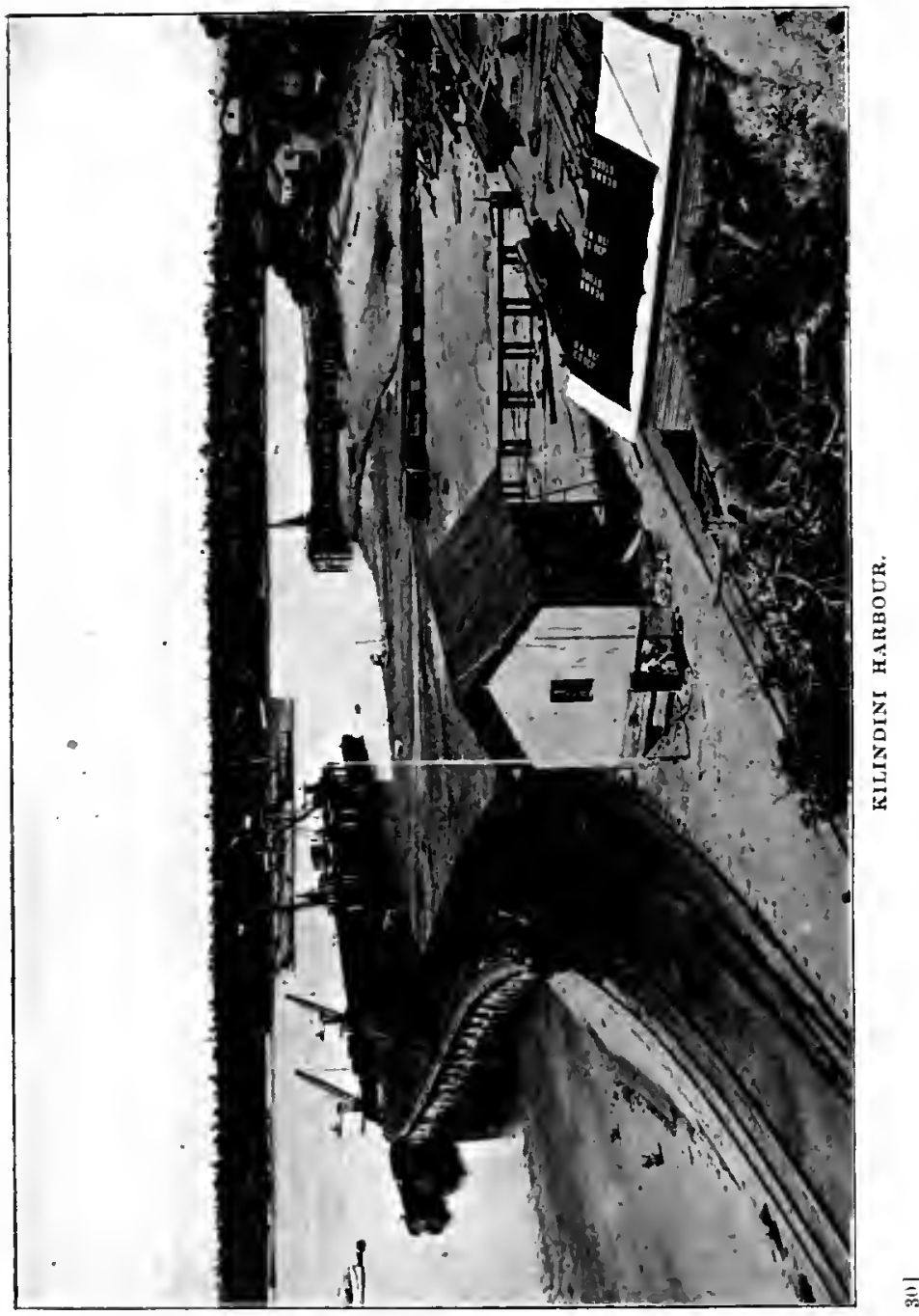


The effect of our little demonstration, however, was good. Aragobeliage came in to the boma next day, was duly fined, and told to be a good boy, and I believe that since that day no other armed raid or demonstration has been necessary in the Lumbwa country, while, in the expedition in 1905-6 against their kindred tribe the Nandi, they refused to come to their aid and to give shelter to refugees and cattle.

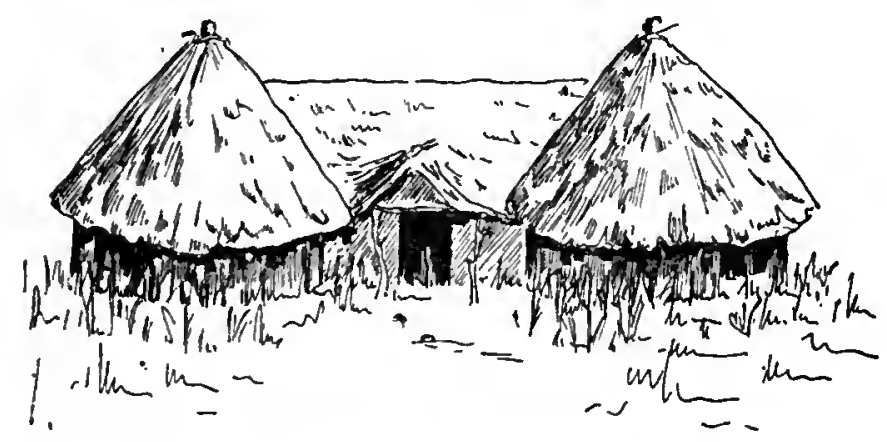




\section{CHAPTER IV}

UGANDA, UNYORO, AND THE NILE

During my stay at Kericho I was unable to get any shooting, as the dense population had long since denuded the country of game. However, my return to Fort Ternan a few months later put me into good shooting country, and I managed to bag roan antelope, Jackson's hartebeeste, topi, and water-buck, as well as the smaller reed-buck and oribi. Nothing extraordinary occurred during my stay at Fort Ternan, save my creating what I fancy is a world's record, by travelling to Zanzibar, where the nearest dentist resided, in order to get a tooth stopped. The distance there and back is some 1,500 miles, which, as I say, must be somewhere about a record for a visit to a dentist.

Then, after a brief visit to England on medical grounds, I found myself in June 1903 once more back in Africa. For the first time I crossed that greatest of inland seas, Victoria Nyanza. I made the journey in the Governmont steamer, Sir William Mackinnon, com- 
monly known as the William Emetic, and though the weather was comparatively calm, I quite appreciated the reasons for the cognomen.

Arrived at Entebbe, then the headquarters of the 4th K.A.R., I got my orders for Nimule, the headquarters of the Nile District. In those days the Nile District, which extended from the Somerset Nile northwards to Gondokoro, enjoyed an extremely bad reputation on account of its excessive unhealthiness. At all its three stations-Wadelai, Nimule, and Gondokoro-malaria, spirillum, and the dread black-water fever were rife. Although the excellent shooting somewhat counterbalanced these evils, yet the record of deaths and invalidings was anything but encouraging to any one proceeding for the first time to those parts.

However, with a firm belief in "Kismet," I set forth, without being unduly depressed with forebodings for the future. My route lay via Kampala, and thence, via Hoima, to Butiaba on Lake Albert, where walking ceased-for so far the journey had to be performed on footand I was to embark on one of the Government boats and travel the rest of the way by water.

Of the journey overland nothing need be said, as very little of interest occurred, save that at various camps I enjoyed good shooting, 4 


\section{UGANDA, UNYORO, AND THE NILE}

and saw for the first time a large herd of elephant, which had travelled along the road for some miles, not doing it any great amount of good in so doing, and which had made hay with the telegraph line whieh ran alongside the road. At this time, and for all $\mathrm{I}$ know up to to-day, elephants played the very deuee with the telegraph service, tearing down poles, breaking wires, and ereating general havoe.

The distance from Entebbe to Butiaba took thirteen days' hard marehing, for the most part through populous and cultivated country. Marehing in Uganda and in Unyoro is to my mind a remarkably uninteresting performance. The road is bordered either by continuous banana plantations, or a dense growth of elephant grass, shutting out any kind of view, and keeping off any breeze which there may be. There is a considerable amount of up-anddown grade marehing. Every hill one crosses is covered with dense vegetation, and in every valley one drops into a swamp, through which the road, supported on a causeway of logs, wends its winding way. The only good thing about such travelling is the system of eamping-grounds, at each of which the local ehief receives an annual subsidy from Government for the provision of food (almost entirely bananas, the staple diet of Uganda) to the various caravans which halt therc. Owing to 
this system the white man is usually enabled to procure such luxuries as milk, eggs, and fowls, at moderately reasonable prices. Apart from occasional possibilities of shooting, the journey from Entcbbe, as far as Hoima at any rate, is the very essence of monotony.

For the benefit of any one interested in such a journey I give an extract from my diary, which is a pretty complete description of every day :

"Saturday, 20th July, Camp Busibica.Started at six a.m. this morning and arrived here about two p.m. The road led through very thick country; dense elephant grass on both sides, making any view impossiblc. Crossed many swamps on the usual causeway. Very little cultivation to be seen, but there may be any amount away from the road. Saw no game on the march. After tea left camp at about 4 o'clock with a native I had sent out to look for game. Some little distance from camp we caught a glimpse of eight buck, which looked like young hartebeeste, but grass was very thick, and I couldn't make them out exactly. Tried a long shot and missed. Shortly after got a fair kobus kob, one shot at 120 paces ; could only see his head over the tops of the grass. Got back to camp about seven o'clock, rather tired."

However, the most monotonous of marches must end, and in due course of time $I$ reached Butiaba, where I found two Europeans, ope a 
namesake of my own, and like myself bound for Nimule. He was going off the next day in the steam-launch, and as two on board were rather a crowd, I decided to wait for the departure of the steel sailing-boat James Martin. The day after my arrival an excited native appeared with news of elephant near at hand, and the following day I started off at three a.m. to have my first encounter with Elephas gigans. At about ten o'clock, after six hours' stcady tramping, we arrived at a small river, where we were met by a native, who told us that the elephant were close at hand. Hastily crossing the stream, we found ourselves in a dense tangle of elephant grass, intersected with elephant tracks, to follow which was the only possible method of traversing the matted vegetation. As I was an absolute novice at elephant-hunting I allowed my gun-bearer (an old hand whom I had borrowed for the day) to lead the way. After twenty minutes of twisting and winding in the twelve-foot grass, we began to see signs of our quarry: freshly broken trees and bushes showed where they had made their morning meal, and some still smoking droppings showed us that we were close upon them.

A hasty climbing of trees ensued, and from the prickly branches of an acacia I spied two broad backs, red from the earth with which 
they were covered, while the gentle flapping of four enormous ears could be seen. A descent and consultation followed, as a result of which we made a big circle round, by devious tracks, so as to come upon them up wind. After half an hour's manœuvring I heard for the first time that strange internal rumbling which so gives away the presence of elephant. Cautiously we pressed on, myself in advance, and, rounding a bend in the path, four tuskers were revealed to my enraptured gaze. Being, as I have said, a novice, I didn't know a bull from a cow, and as there are considerable penalties for shooting the latter, I consulted my fidus Achates, the gun-bearcr. "Ndumi yoti" (all bulls), he answered. "Pega pace" (fire quickly). This was good enough for me, so, selecting the one which seemed to carry the biggest tusks, I drew a bead on his head.

Had I known more about it I should have got a bit nearer, as the elephants were a good seventy yards off, and an elephant's brain is a pretty small mark. Moreover, we had not disturbed them, and they were all placidly standing, their huge ears slowly flapping backwards and forwards. However, as it was I was madly excited, and let fly a solid bullet from my Rigby Mauser at the head of my destined victim. He staggered, and half sat down, while his three companions swung 
round and vanished into the long grass. Snatching my heavy double eight-bore from the gun-bearer, I dashed up the path towards the wounded beast, and planted both bullets into him as he rose and staggered off. Reloading, we advanced, and found from the heavy blood spoor that he was bleeding freely.

The gun-bearer recommended giving him time to stiffen a bit, and assured me that he could not go far. ${ }^{1}$ Accordingly I sat down and devoted my attention to the lunch-basket I had brought with me. After lunch I sat and smoked, but surely never did tobacco burn so slowly as during the two hours I waited. At length the gun-bearer allowed me to go ahead, and we started to follow up the blood-spoor. For hour after hour we followed, disturbing en route a solitary elephant, which we almost walked into. The track wound in and out, backwards and forwards, circling here and there, and I don't imagine that in our three hours of following we ever went outside a four-mile square of country. This is most unusual, as a wounded elephant generally makes off across country in a bee-line. However, this one was bleeding very heavily, and, to cut a long story short, at about five o'clock we came upon him, looking

1 Incidentally, this was entirely incorrect: a wounded, olephant should be followed up immediately. 
very sick, standing in the shade of a big tree. Cautiously approaching to within some thirty yards, I raised the eight-bore and drove a bullet into the tiny orifice of the enormous ear. Slowly he sank down upon his knees, and still slowly, lurching over, fell upon his side. He was dead, and I had killed my first elephant.

I don't think that at that moment I would have exchanged positions with the Commander-in-Chief. Next to getting one's colours at school I think the most absolutely blissful moment of a man's life is when he sees his first elephant drop dead. In my case the bliss was quickly succeeded by a sensation of pity that so big a beast should have been cut off in his prime, which is, I believe, a feeling that most men experience under similar circumstances. I know that I felt it very strongly. However, the unrestrained joy of my entourage roused me rapidly-from my gloom, and having cut off the pachyderm's tail, the African equivalent to the brush, I gave direction for the chopping out of the ivory. This somewhat lengthy operation was continued after darkness fell by the light of grass fires and flares. As there was very little chance of my being able to do the necessary and difficult curing, I forbore to take a foot, which is about the only other trophy an elephant offers. By the time the chopping 
operations were concluded, it was after nine o'clock, and as we were some distance from Butiaba we did not arrive there until nearly twelve. Hungry, thirsty, footsore, and dead tired as I was, I imagine that Africa contained few happier and more contented men than I, for I had slain my first elephant, and the spoils of war-two eighty-pound tusks-were being borne proudly behind me.

After a stay of a week at Butiaba, spent mainly in shikár, without any startling "bags," our boat was ready to sail, and I embarked for Nimule. The scenery on Lake Albert is very fine. The lake is surrounded by hills, at the foot of which lies a strip of flat plain, varying in breadth from several miles to a couple of hundred yards. In most places the hills fall in a sheer escarpment down to the plain below, especially on the western shore, where the cliffs seem to fall sheer into the blue lake waters. Down the black, frowning rock-face flow many torrents and falls, which can be distinguished with the naked eye across the lake.

The James Martin made good way while on the open waters of the lake, and, being cutterrigged, was able to sail well into the wind. However, once the lake was left and we entered the comparatively narrow channel of the White Nile, nothing much in the way of sailing could be done, unless we had a.following wind, 
and we had to depend on our eight oarsmen and the strong current of the river. As we made our way onwards and the country opened out before us, I was shown the station of Mahagi, now occupied by the Congo Free State, and not long afterwards we passed the junction of the Somerset or Victoria Nile, which joins the White Nile just below Fajao.

The sight of these two places brought inevitably to my mind the names of the two men with whom, to me, they were inseparably associated, men whose brilliant service to the Empire will of a surety never be forgotten as long as an African Empire exists, and so long as the traditions of the British Army remain. There is a curious similarity about the two careers. Both men were young and ardent soldiers, endowed with that military instinct and administrative genius which stamp the born leader of men. Both were men of a singular personal charm, and to each was the pen power of the polished writer. Each of them has put on record that strange charm, that subtly compelling fascination that Africa instils into the veins of those that know her, and we know from their writings that each of them was in that strange, sweet bondage. Both their lives were inseparably bound up with Africa. There their first chance came and their names were made. 


\section{UGANDA, UNYORO, AND THE NILE}

There they carved names in the rock of time by deeds and sterling qualities which gave fair promise of brilliant careers held in store by fate for each of them. And there each met untimely death. The Sudanese mutineers at Lubwa's Fort, and the Dutch burghers at Hamman's Kraal, when they cut off in the flower of their manhood Arthur Blyford Thruston and Seymour Vandeleur, cut short two lives of brilliant promise, which with happier fate would of a surety have climbed to still greater heights of fame.

A journey down the Nile is by no manner of means wildly exhilarating. During the days fies of many varieties, but all voracious and hungry for blood, make life irksome. The best part of the twenty-four hours is when one lands at onc of the camping-grounds, which are arranged at. regular stages along the British bank. One sleeps ashore every night, and the crew obtain food from the local chief at these camps, while the white man can likewise purchase such luxuries as eggs, fowls, milk, etc. Usually one lands about four p.m., and there is time for a ramble round with a rifle before darkness falls-quite the most fascinating period of the day this.

We reached Wadelai in three days after leaving Butiaba, and spent a couple of days there. At that time the European population 
of Wadelai consisted of the Collector-tout seul. A doctor was expected, but the date of his coming was uncertain-as were most things in that part of the world. The British Station of Wadelai (now abandoned) was on the opposite bank to Emin's old station, then occupied by the Congo Free State, and about three miles farther up stream. Its climate was unhealthy, the accommodation bad, the heat intense, and flies, mosquitoes, and other pests, insect and reptilian, swarmed and thrived. Altogether I should imagine that it was one of the most absolutely infernal places of residence on earth for a solitary white man.

Here I found Major Powell Cotton, the wellknown explorer and naturalist, who had just returned from an unsuccessful okapi-hunt in the Congo Free State. He came on to Nimule in the James Martin with me, and his presence aboard gave an additional interest to the voyage, for I heard at first-hand many of his out-of-the-way experiences and adventures in unknown lands and amongst unknown people. He was just finishing the journey he describes in "Through Unknown Africa," and his experiences were most entertaining, and though my insatiable curiosity must have bored him horribly, he was always ready to gratify it.

A detailed account of our voyage would be the dullest of dull reading, but perhaps a 


\section{UGANDA, UNYORO, AND THE NILE}

description taken from my diary of one day of a subsequent voyage on the Nile may give some idea of one's daily life. At all events here it is :

\section{"A Day on the Nile.}

"The Nile! What scenes does not that one small word conjure up, alike to traveller and stay-at-home? Those four letters carry in their train visions of Cairo, the city of Harounel-Raschid. Sphinxes, pyramids, and temples, Bedouins, dahabeahs, beggars, donkey-boys, and dragomen, flash past in kaleidoscopic procession. Luxor, Karnak, Assouan, Khartum -all names that bring back pictures of the mighty river gliding silent through the ancient land of mystery, whose very life it is. And in this twentieth century, even the few whose eyes have not gazed upon these scenes can tell, thanks to multitudinous pens and cameras, as much as, or mayhap more, than those others who have sojourned in the land of Khem. I say the stay-at-home few, for in these days of cheap travel and Thomas Cook one meets all London, Paris, and New York in the verandah of Shepheard's in the season.

"Yes, old Nile, even far south to distant Gondokoro, is now as well known and as much the world's playground as the Thames at Taplow or New York's Hudson.

"It is not, however, of this river of pleasure I write, but of another stream, where swamps and barren hills take the place of palaces and temples, where the deadly scourge, malaria, lifts its head unchecked, and where a handful of white men, isolated from their kind, deal 
out the white man's justice and uphold his sway over the black sons of Ham.

"Take your atlas and travel with me up the mighty river. No boat can take us, for we make our passage together over falls and rapids, whirlpools and torrents. Past Luxor, past Assouan, past Khartum, past the mouth of the Bahr-el-Arzek, the Blue Nile, born in the snow-crowned Abyssinian mountains, past Fashoda, where ended Marchand's heroic march, past Gondokoro-southwards we go and still farther south until Egypt and the Sudan are left behind, and the ship of our imagination floats on the broad stream which divides the British Protectorate of Uganda from the Congo Free State. We have reached the country of Samuel Baker, of Gordon, of Emin. Let us halt for a brief moment at Dufile, Emin's old capital of Equatoria, where till the other day his house still stood, now a station in the Lado Enclave of the Free State. Between Dufile and Wadelai, Emin's later capital, stretch for some hundred and twenty miles the upper reaches of the White Nile, the Bahr-el-Abiad. Your atlas, if it be a good one, will tell you that these waters have the name of Bahr-el-Jebel-the River of Hills, and it is of a day spent on this stream as I journey from Nimule to Wadelai that I write. My old diary, frayed and travel-stained, is before me, and as I copy its blurred pages I am sitting once more in the blazing heat of the African sun, with the song of the Swahili boat-boys in my ears and the strange charm of Africa in my heart, and whilc the eternal stream on whose breast I float glides downwards to the land of Misr and the landlocked sea, I live 


\section{UGANDA, UNYORO, AND THE NILE}

again for one brief hour that day on which these stained and blotted pages were written.

"It is ten a.m. on a November morning, and we are at anehor on the waters of the Nile ; or rather, our boat is tied up to one of the dense beds of reeds and papyrus which border both banks of the channel. We, that is myself, an officer of the Congo Free State service, and a Goanese clerk from Gondokoro, are en route from Nimule to Wadelai, and this is our seventh day out. We are aboard the Uganda Protectorate steel boat James Martin, and are fighting our way against wind and current, a eurrent which runs from five to nine miles an hour. Our boat is cutter-rigged, some thirty-five feet long, broad in the beam, and fitted with cight oars, four a side. So far we have had only half a day's favourable wind, and the work has been hard for our oarsmen. Out of a erew of ten and a 'nahausa' or coxswain, one is sick, so there are practically no reliefs at the oars.

"Last night we were unable to make a camp, for the river here is two miles or more in breadth, and both banks are bordered with a broad belt of papyrus and rushes, through which it is impossible to foree a way for our large boat. Large patches and islands of the same growth, with sud ${ }^{1}$ as a basis, cover the face of the waters, and between them the narrow channel twists and turns. Therefore,

1 Sud. An Arabic word, meaning sioge, blockade. The name of a small cabbago-like plant which floats in thousands on the Nile, and, collecting in masses, forms islands on which reeds and othor vegetable matter grow and form a serious obstacle to navigation. 
yesterday, after fighting the current from six a.m. to nine p.m., with intervals of rest for the rowers, our eraft tied up to the rushes, we have given up all hope of reaching a village, and have made fast to the reeds for the night, sleeping in our clothes on the wooden seats of the boat. My companions complained this morning of the mosquitoes, but $I$, being tough-skinned, have not noticed them much.

"To-day we started at about five a.m. and must have made quite two miles when the head wind which is our undoing springs up. We are drifting backwards at every stroke, so, regretfully enough, I give the order to make once more for our city of refuge-the reed-bed -and here we are, hard and fast in the sweltering heat of an African morning.

We three are aft under a brown canvas awning. My two companions have occupied all the available sleeping-room, and are stretched out in a deep slumber. The breeze, which is sufficient to bar our forward progress, does not suffice to cool in any great degree the blistering heat. It is, however, strong enough to carry aft the many and curious odours which emanate from the bows and amidships of the vessel. I think that sunbaked nigger predominates, but there are several others strong enough to be easily recognizable. My unfortunate nose receives impressions of fish drying in the sun; meat also, undergoing a similar treatment; part of our crew's ration these, and counted a delicacy, though to European palates a trifle 'gamey' perhaps-at least, so says my olfactory sense. Whiffs of wood smoke reach me, for we have 


\section{UGANDA, UNYORO, AND THE NILE}

a fireplace aboard, on which even now I imagine that fat is frying, for $I$ ean hear its crackling splutter, and the wind brings me testimony of it, mingled with the acrid smell of native tobacco. Altogether an entirely African atmosphere.

"Over the whole scene hangs a deep silence, broken-and curiously enough seemingly intensified thereby-only by the chatter of the natives forrard-chatter in which divers tongues are mingled. The Kiswahili of the crew, the bastard Arabic of my five Sudanese soldiers, Dinkas and Shilluks from the neighbourhood of Fashoda, and some strange West Coast dialect spoken by the retainers of my Belgian, or rather Italian friend. For there are men of all nations in the Congo Service, save only Anglo-Saxons. In the past the methods of the English-speaking races have clashed with the theories of government held by Leopold's Administration. The view from the boat is picturesque enough; the channel, here some five hundred yards in breadth, bordered by the dense growth of verdant papyrus, extends due north and south some hundreds of yards above and below us; then in each direction a bend. In mid-channel the river rushes along with a nine-mile current, bearing with it much sud, ranging from single small plants to large islands two hundred yards square, overgrown with rushes, papyrus, grass, and in many cases fair-sized trees. They have come from distant Toro, these islands, from Lake Albert Edward, and will in due course arrive and swell the vast unexplored region of swamps and sud north of Gondokoro, a little the worse for their passage over the 
rapids and falls which commence at Nimule, but still more or less intact.

"A curious plant this sud-the single plant being somewhat like a small cabbage, with long feathery roots which trail beneath the surface of the water, and which wrap and twine with the roots of other plants with which they come in contact, till at last there is the broad island, ready for the inception of other vegetable life. A constant source of trouble and difficulty in navigating the river are they, for once let a channel become blocked by one or more islands-a matter of common happening-and the constant river-born supply soon forms a formidable obstacle, if not an insurmountable barrier-possibly entailing the cutting of a new channel. To the east is the British bank, with a range of high hills, covered with long, rank grass and thick acacia scrub, running parallel with the bank, close down to the water's edge. Along the crests rises the heavy smoke of many grass and jungle fires, telling that the rains have ended and the dry season commenced.

"On the Belgian shore the ground is lower, and the main features are rolling uplands, running at right-angles to the stream, with the drab smudge of distant hill-tops against the azure of the sky. The long grass and scrub are here also, but smoke there is none, which is a somewhat significant fact, for it tells that there are no natives, and we know as a fact that the left bank of the Nile is practically uninhabited, all the natives having elected to cross the river, rather than remain under the sway of 'Leopold \& Co.'

"Two hundred yards below our craft a 


\section{UGANDA, UNYORO, AND THE NILE}

school of hippo. are playing. I forbear from shooting, as, though the meat would be welcome to our men, I realize the improbability of recovering the body in this current; therefore I content myself with studying them through my field-glasses, and very interesting I find them as they ponderously disport themselves. Presently a cry of ' mamba' forrard takes my attention from the pachyderms, and I see the 'mamba' himself floating down with the current-in plain English a crocodile, and a big one at that. Here no considerations affect my shooting. He is vermin, and must be treated as such. Before my eyes as I seize my Mannlicher floats a scene that it was once my evil fortune to behold. A brown, sluggish stream, whose unruffled, oily waters flow smoothly and silently between banks carpeted and crowned with lush, tropical, emerald foliage. At the ford a string of half-naked carriers, each with his burden on his head, are ploughing their way through the breast-high stream towards the farther bank, to the accompaniment of dropping rifle-shots from the bank into the water on either side of them-the one resort to keep off the scourge of the African rivers, but alas! not always efficacious. Half the caravan has crossed, when suddenly a load slips. The porter reaches out for its recovery, stumbles, and falls forward, and a lurking saurian-bolder or more hungry than his fellows-sees his chance. A sudden swirl, one shriek of agony and despair, a crimson stain on the brown eddies, and beneath the turgid waters porter Juma Masudi has met his God.

"My finger tightens on the trigger, and this 
' mamba' continues his course down-stream -belly upwards, and I know that he will furnish a feast for his loathsome brethren.

"The noise of my shot has not only scared the hippo., but has also awakened my companions. The Italian comments somewhat forcibly on the situation in French-the only language we have in common, and then sleeps once more. The Goanese, however, rises and moves from under the awning to the small poop, where the breeze is more in evidence, and I promptly occupy his vacant place, and in my turn sleep.

"I am awakened at two o'clock for lunch, which consists mainly of chicken. How I have learned to loathe that erstwhile delicacy! In the Nile Valley meat is scarce in the rainy (and non-hunting) season, and chicken forms the staple food. After one has lived for five weeks exclusively on ' kuku,' the very sight of it repels one. In addition it is far too hot to eat much, so I content myself with tea and biscuits, and settle down to letter-writing, while my fellow-voyagers again retire to rest. By three o'clock the heat is stifling, for the breeze has dropped altogether, and there is not a breath of air; but we can resume our way. My fellow-travellers still sleep, undisturbed by the songs of the Swahili rowers, not altogether unmelodious in their long-drawn minor cadences, but somewhat monotonous after several days of hearing.

"My servant is on the poop, catching fish -or rather fishing. He has been thus occupied ever since we left Nimule-so far his catch has been nil. I ask him if he is quite sure that he knows how to fish. He becomes 


\section{UGANDA, UNYORO, AND THE NILE}

indignant, and assures me that he is a most expert angler, but that the fish here are very bad fish, and even if caught not fit to eat; that perhaps, indeed probably, there are no fish in the river at all, and that he doesn't want any, anyway! A clear case of sour grapes!

"By this time it is five o'clock, and we tie up once more to the everlasting reeds for an hour's rest for the hard-worked rowers, who have been pulling magnificently, like very galley-slaves. At 6.30 we shall start again, and keep on until eleven. In the coolness of the night the crew can pull better than in the day's broiling heat. At seven we shall dine off the eternal chicken, with anything else that my cook can devise, and when we tie up at eleven we bed down fully dressed on the seats, with the trumpeting of a herd of elephant and the song of myriads of mosquitoes to lull us to sleep. As a matter of fact I'm the only one who gets much sleep at nights-though my companions make up for it during the day. Besides my natural tough hide I can sleep like a native, with my blanket over my head - a feat which neither of them can manage. Wherefore the mosquitoes have much food, and my companions little sleep.

"At five to-morrow morning we shall start on another day, the replica of this one, unless the gods be kind, and send us a favouring wind, which will mean a camp, a bath, a bed, and a mosquito-net, to say nothing of a much-needed rest for our hard-worked crew." 


\section{CHAPTER V}

NIMULE-THE NILE VALLEY-JINJA

OUR arrival at Nimule was unpropitious. The rains were at their height, and the landingstage was under water, as was the road in rear of it for some hundred yards. Some wellmeaning individual had tried to rectify the latter by dumping quantities of brushwood on it, with the result that the path resembled a submerged wire entanglement. Cotton and myself were hoisted on to the shoulders of two sturdy sailors to be carried over the hundred yards between us and dry land, but the subaqueous abbatis was too much for our human steeds, who both took heavy "tosses," sending their riders headfirst into the muddy water.

On reaching terra firma we made our dripping way to the military station, situated on a hill some distance from the newly commenced civil lines, which were then being built on the edge of a swamp on the flat land near the riverbank. Here hot baths, a change of clothes, and a plentiful internal application of whisky, 
soon put us on better terms with ourselves and the world in general.

Since the days when I was at Nimule the situation in the White Nile Valley has altered considerably. All the troops have been withdrawn and the civil stations changed and altered for the better, but in the early part of 1903 the Nile Stations were, I suppose, about as complete deathtraps as any British possessions contained. Not a penny of Government money had been spent on the military lines at Nimule, and they had been entirely built by the troops and military-transport porters under the supervision of the white officers.

There were three stone and mud houses built, and a fourth in course of erection. Pending its completion I was quartered in a "banda"-that is, a shed consisting of a wooden framework, made from freshly cut poles, with sides and roof thatched with grass. As this banda had been built for some time, and the grass walls were neither wind- nor weather-proof, while the green stakes which formed the framework had taken root in the ground and thrust forth shoots into the room, it was hardly an ideal residence; also, as the rains were on at the time, and the banda was on a fairly steep hill-side, about three perennial streams rushed gurgling across the floor. 


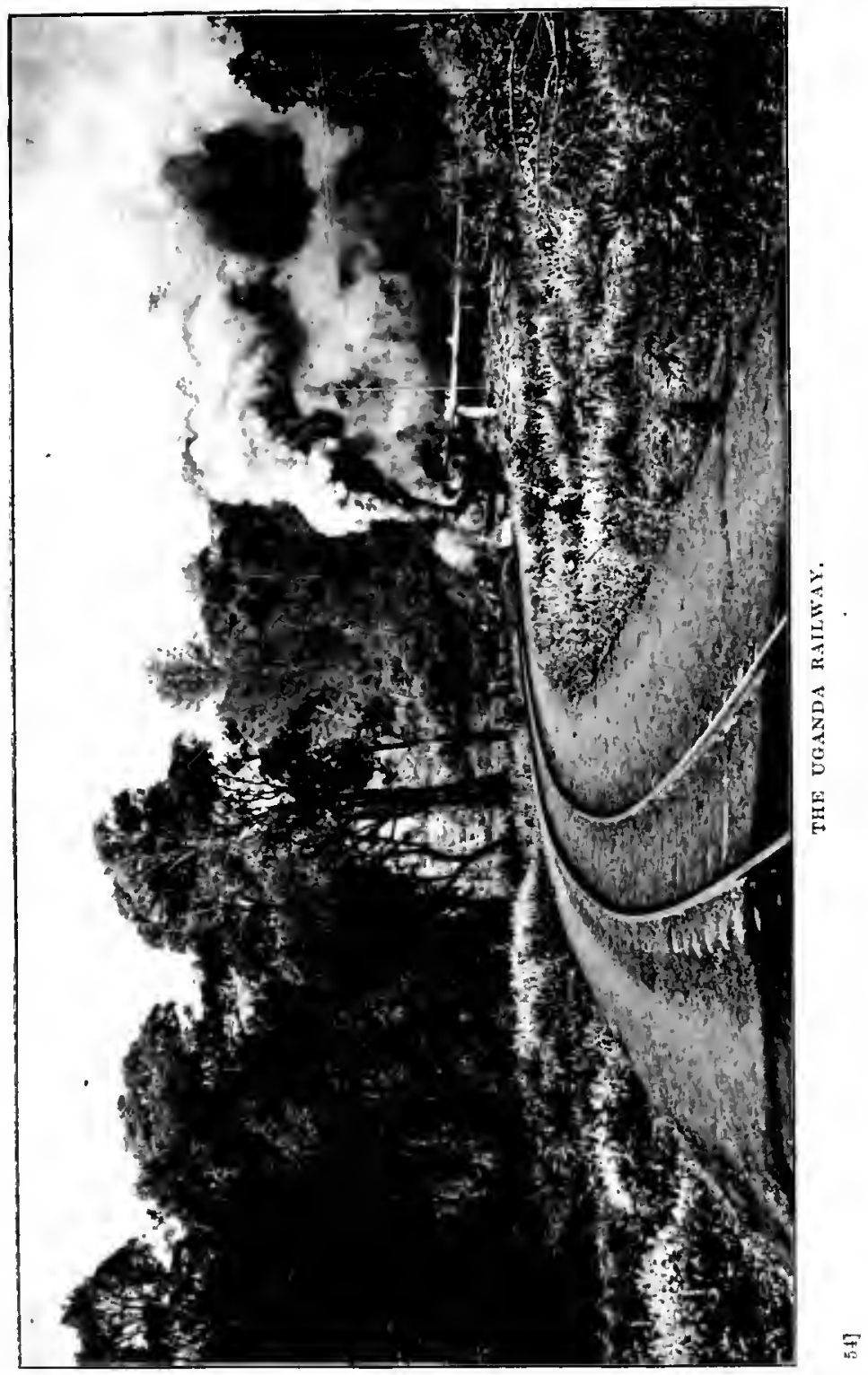




\section{HOUSE ACCOMMODATION AT NIMULE 55}

After one night of this abode, which I spent soaked to the skin and devoured by mosquitoes, I utterly declined to inhabit it further, and quartered myself on Hyslop, who inhabited one of the stone houses. These houses, built entirely by unskilled labour, though probably in England they would be looked down upon, yet in comparison with my last dwelling appeared palatial. Each of them was fitted with two mosquito-proof gauze compartments, one for eating, one for sleeping in, locally known as " meat-safes." The gauze had been bought and paid for by a former officer commanding the Nile District, as no money was obtainable from the Government. Thanks to his generosity one was enabled to cope in some degree with the mosquitoes, which rendered life a misery. Immediately after sunset one was compelled to retire into one's "meat-safe" at peril of being incontinently devoured. An aperture covered by a slide was utilized for handing in food without admitting more mosquitoes than absolutely necessary.

Other forms of animal life which assisted in making life pleasant in this delectable region were jiggers or burrowing fleas, white ants, which devoured all and sundry articles which they could reach, and could only be baffled by Willesden canvas, ticks, and guinea worm, 
which latter fortunately seldom or never turned its attention to white men, though why not no one appears to know. The troops suffered considerably from it, and I suppose that 75 per cent. of the cases of sickness were guinea-worm cases.

For the benefit of such of my readers as may never have encountered any of the above, I will give a brief description of their modus operandi. The jigger or burrowing flea came, I believe, in the first instance from Central and South America, and reaching the West Coast of Africa, spread rapidly across the continent, and was at one time an absolute plague in Uganda and East Africa. Though his numbers have diminished of late years, he is still much in evidence, especially in old earthen-floored buildings, such as stores, warehouses, etc. He burrows into the human skin, generally on the foot, beneath the toe-nails being his favourite spot, and if allowed to remain produces a large sac of eggs, increasing his-or rather her-size from a pin-point to that of a pea. In course of time the sac bursts, and the foot or limb is invaded with a crop of young jiggers who repeat the process. Natives quite frequently lose their feet, and even their lives, from neglect of the jigger. In some cases his entry beneath the skin produces considerable irritation and itching, 
but some people apparently are quite unconscious of the jigger's presence. The easiest way of dealing with them is to have one's feet inspected by one's servant every two or three days. The native is equally adept at spotting them and at extracting them painlessly with a needle. The wound should be washed out with some disinfectant, especially if the sac has been burst in extraction; failing a disinfectant a mixture of cigarette ash and whisky is efficacious.

The guinea worm is more or less an unknown quantity. Its life-history has yet to be discovered. All that is known is that the female frequents the human body for the laying of her eggs, usually selecting an arm or leg. When she makes her appearance on the surface the method of treatment is to wind off a little -about an inch or so-daily on a match or similar piece of wood. This process takes about a fortnight or three weeks, the limb being useless and painful during the proceeding. Care must be taken that the worm is not broken, as if so she retires inwards, and operations have to be recommenced at her next appearance.

Of the African family of ticks much could be written. Suffice to say that, in addition to being an unpleasant pest, they carry the germs of many diseases, both of horses, dogs, cattle, 
and men, the best known and most dangerous being spirillum fever.

The Nile Valley white ant-both in numbers and voracity-probably has not his equal in the world. Whole buildings are wrecked by him, as he devours the wooden framework in defiance of tar and other so-called preventives. I remember once that in one night $I$ had a stout pair of shooting-boots completely devoured, which I had incautiously left on the earthen floor of my room, and not on my Willesden eanvas ground-sheet, on retiring to rest.

From what I have already said it will be gathered that Nimule-and in fact all the Nile Valley stations-were by no means places that one would select of one's own free will as a residence. The climate was deadly. Of the seven of us there-four soldiers, two civilians, and, part of the time, a doctorthere was seldom a day that one or more of us was not down with fever, and the somewhat unusual sight of a bottle of quinine on every dinner-table, and handed round with drinks, was the normal procedure. It took six months to get up stores from the coast; eleven days by native runncrs to the nearest telegraph; transport frequently broke down, with the result that wc were cut off from the outer world, and stores, groceries, whisky, and tobacco 
were exhausted and unobtainable for weeks or months at a time. Meat, with the exception of game, which could only be got in the dry season, was practically unobtainable, our staple diet being chicken. The only vegetables that would grow in the station garden were tomatoes and a species of weed resembling spinach; potatoes and onions were brought up from "down country" with our other stores, and, like them, vanished from our menu in times of stress.

An occasional visit of our Belgian friends from Dufile, the arrival of a shooting-party en route for Gondokoro and Khartum, or a stray trader, livened us up now and then. Once a missionary-the first and I believe the last to visit those parts-arrived. He livened us up also ; but in a different manner. If any of my six fellow-sojourners of Nimule should chance to read these pages they will understand and appreciate my meaning. It is perhaps unnecessary that any one outside that small circle should do so.

The two consolations of Nimule were, first, there was plenty of work; and secondly, the shooting. Although I was not there in the dry season, when the shooting is really first class, owing to the long grass being burnt, yet I managed to get a good deal of sport even during the rains by going out after elephant- 
the only species of game which can be pursued at that time, owing to the rank vegetation which covers the face of the land and renders the pursuit of anything smaller a matter of impossibility. Of my adventures with elephant more anon; suffice to say here that the big pachyderm provided ample occupation for my spare time.

A few months of Nimule sufficed to saturate me with fever, and as I had been none too fit when I arrived, the medical authorities decided that the Nile Valley was no place for me, and pushed me off down country. On reporting myself at Entebbe, I got orders to take over the company at Jinja, and accordingly set off by canoe on Lake Victoria, arriving at my destination on Christmas morning, 1903.

Jinja is situated on Lake Victoria at the spot where the Somerset Nile leaves the lake, and close to the station are the celebrated Ripon Falls. I had heard a great deal about them, but personally was greatly disappointed in them, as $I$ think are most people on seeing them for the first time, though $I$ found that after a time there was a certain fascination about them. The drop is very small, and I'm convinced that if they didn't happen to be on the Nile, nobody would take much interest in them.

Jinja, which I believe has since been rebuilt, 
and which is now, I believe, a flourishing township, was at the time I write of the ordinary wattle-and-daub African station. It was by no means a health-resort, and black-water fever was pretty common there. The white population consisted of two civil servants, one married, two soldiers, and a doctor. There was a distinct lack of occupation, the chief excitement being the arrival of the weekly steamer. Shooting was practically non-existent, owing to the comparative density of the population and the thickness of the scrub. The only things to be shot were crocodiles and hippopotami, both of which simply swarmed. The former we all classed in the same category as snakes and suchlike vermin, as enemies of man, to be shot on sight. The latter were a perfect pest, as they not only frequently, attacked canoes, but they also came ashore nightly and devastated the "shambas" or gardens of the local population. The Commissioner, Colonel (now Sir James) Hayes Sadler, on this account, not only repealed locally the regulation by which only ten could be shot annually on a game-licence, but when he visited Jinja asked us all to kill as many as we could. The consequence was that the hippos. had a rather unhappy time, but their numbers did not appear to materially decrease. Shooting them in the river, where 
they mostly were, was an unsatisfactory form of amusement, as one practically never secured a trophy. The force of the stream, both above and below the falls, used to whirl them away down the rapids, probably to the great benefit of the inhabitants miles down stream, who must have reaped a rich harvest of teeth, meat, fat, and skin. I remember one Sunday shooting seventeen below the falls and not being able to collect one. Of course this was mere butchery, but, as I have said, they were pests.

Coming back one night from an attempt to secure a few, I got overtaken by darkness, and suddenly my canoe struck what I thought was a rock with a fearful bump. I felt the bottom of the canoe grating as it passed over the supposed rock, when suddenly there was a deuce of a heave, and I' realized that the rock was a hippopotamus. Snorts and splashes from all round showed me that we had got right into the middle of a school of them, and, knowing their evil reputation for attacking canoes, I was in rather a funk, as it was pitch-dark and the lake swarmed with crocodiles. I hung on to my rifle and the crew paddled for dear life, and we were lucky enough to get quit of the hippopotami without any trouble; but after that I was jolly careful not to be on the lake after nightfall. 
While at Jinja I had opportunity for observing the progress of that dread scourge, sleepingsickness. Jinja was the centre of a district which had been ravaged by it, and it was almost impossible to get a complete crew of adults for a canoe in consequence. Despite the efforts of science and the self-sacrifice of devoted doctors, very little is known about it even now. No cure has yet been discovered, and the Government has only been able to check its appalling ravages by removing the lake-side population some distance inland, for sleeping-sickness apparently cannot exist far from large sheets of water, even in tsetse-infested country.

After about six weeks of Jinja I was transferred to Nandi Fort, where my old company had been moved from Fort Ternan, which had now been abandoned as a military station. Nandi, being about 6,000 feet above sea-level, in a cool, healthy country, was a welcome change after my last two stations, more especially as there was always the chance of service there. The Nandi were a very truculent crowd, and were always giving trouble of one kind or another, their most favourite amusement being to cut up the railway coolie gangs in the Nyando Valley, and retreating with a crop of fish-plates, bolts, etc., back to their hills. They were also fond of cutting up small parties 
64 NIMULE-THE NILE VALLEY-JINJA

on foot on the road between the stations, especially if soldiers or police were of the party, as in that case rifles and ammunition formed part of the loot, even though one or two casualties were incurred. 


\section{CHAPTER VI}

NANDI-KABWAREN-NGONGO BAGAS

I Celebrated my arrival at Nandi Fort by an attack of black-water fever, the germs of which I imagine I had collected either on the Nile or at Jinja. Fortunately the attack was a very mild one, and by the time that a doctor had arrived from Port Florence, I was out of all danger. During the few months which I spent at Nandi Fort on this occasion, I took part in one or two small punitive expeditions with the Collector, Mr. W. Mayes, and had my first experience of poisoned arrows. Most unpleasant, too, I found them. In these days of magazine rifles, machine-guns, and other highly developed aids to scientific slaughter, the mention of spears and bows and arrows sounds reminiscent of opera-bouffe, and rouses a more or less pitying smile from the professional soldier and a howl of indignation from the no less professional humanitarian agitator at the iniquity of pitting troops armed with the above-quoted mechanical death-dealers against (invariably) ignorant, innocent, and 


\section{NANDI-KABWAREN-NGONGO BAGAS}

inoffensive savages armed only with mediæval weapons.

Of course I grant that ultimate victory must invariably rest with the rifleman, but it would afford me considerable enjoyment to conduct personally one or more of the aforesaid humanitarians upon one of the barbarous butchering expeditions against which they rise to such heights of vituperative declamation. Imagine, then, to use a hackneyed phrase, one of our African "outposts of Empire." The deep ditch surrounds the wire-entangled stockade, bastioned for covering fire, within which are the house of the Collector and the various Government offices. Outside at some little distance are the military lines, regular rows of wattle-and-daub huts traversed by broad thoroughfares. At one end of the lines huts somewhat larger than the rest denote the guard-room, magazine, stores, orderly room, etc. Beyond them the broad open space of the parade ground, on the other side of which is a small cluster of buildings-the house, servants' quarters, etc., of the white officer. Both of these, like the seat of civil government, are stockaded, ditched, and wire-entangled, and the surrounding scrub cleared for riflefire against sudden attacks of the local population, should they happen to feel a bit above themselves. Close under the civil fort, or 
"boma" in local parlance, lies the native bazaar-a few mud shops tenanted by the ubiquitous Indian and Somali trader, and the huts of such of the local savages as have elected to set up their Lares and Penates under the ægis of the "Sirkari " (Government), in whose employment as herdsmen, messengers, labourers, etc., they earn a wage which to them represents extreme affluence.

Imagine, as I say, some such scene as this, lit up by and warmed by the morning sun of Africa. Everywhere in the tiny station is a scene of bustle. On the parade ground the company of troops are performing various evolutions under the watchful eye of their officer. A crowd outside the Collector's office indicates that he is dispensing justice (strictly in accordance with the Indian Penal Code). The bazaar is filled with a chattering, bargaining crowd of natives, buying and selling, chaffering, gesticulating, and shouting. Suddenly up the main road to the post, through the busy bazaar, comes a single man, hurrying, half running. There is a sudden hush in the bazaar, then a fresh burst of louder clamour and chatter. The running figure has passed the bazaar, leaving in his wake a buzz of wagging tongucs-a chattering, gesticulating crowd. He enters the civil "boma," brushes through the waiting litigants, and enters the 
Collector's office. A minute afterwards a police orderly emerges, and makes at a steady double for the parade ground, where he hands a note to the officer. It is brief and to the point. "The Kapsumu cut up a Swahili trading caravan yesterday. Survivor just come in with news. Am going to teach them a lesson. How soon can you start?"

Parade is dismissed-a few brief orders to the native colour-sergeant and the headman of the military-transport section, one hundred sturdy porters, the transport animal of Africa. A few instructions to his orderly re the packing of personal kit, and the officer hurries off to confer with his civilian confrère. Two hours later a compact little force, fifty Sudanese soldiers, one Maxim-gun, twenty military police, under the two white men, with transport, ammunition, stores, and supplies for a week, move out along the track to Kapsumu, leaving the fort in the capable hands of the Arab colour-sergeant, Masud wad Ibrahim, and his Sudanese confrère of the police, Sergeant-Major Mursal Said.

Some nineteen miles are covered that day, and in the evening camp is pitched, surrounded by a strong thorn zeriba, near the scene of the previous day's massacre. While camp is being built the white men, with an escort, go out and view the spot where the ambush was laid. 
Eight Swahilis have been killed, and their bodies-or what is left of them-are lying contorted in the thick forest shade. The forest seems to have protected them, for, curiously enough, neither jackals nor vultures have touched them, and the two white men are thus enabled, previous to burying according to Moslem law the bodies of the killed, to view in its entirety the handiwork of the Kapsumu. It is not a pleasant sight, nor one to be dwelt on at any length, but it is one of many details invariably omitted by the stay-at-home champion of the noble savage in the highly coloured picture which he paints for the delectation of all and sundry.

At daybreak the next morning the Government interpreter, with a friendly local sub-chief and five soldiers, are despatched to request the presence of the chief of the Kapsumu in camp. Strict orders are given against firing except as a last resort. Half an hour after leaving camp the herald's deputation is back without having fired a shot, one soldier with an arrow (fortunately not poisoned) through his left shoulder; the said arrow, together with sundry verbal insults, being the only reply to a pacific message shouted by the interpreter to a group of Kapsumu. Commending the soldiers for not returning the fire or committing any hostile act, the friendly sub-chief is instructed 
to go alone and deliver a formal message to the recalcitrant chief, summoning him to a conference with the Collector. He returns about four p.m., and reports that the chicf entirely declines the Collector's invitation, that he is collecting his elmoran or fighting men, and that he has charged him to deliver various unrecordable messages as to what he purposes doing with the Collector and the whole of his force. This indeed is the final throwing down of the gauntlet; nothing now remains but an appeal to force.

Night is rendered pleasant by intermittent flights of arrows into camp, to say nothing of wild ycllings and threatened charges of spearmen, which, however, get no further than threats. In the grey of the morning, leaving twenty rifles to guard camp, the remainder of the force emerges from the shelter of the zeriba en route for the kraal of the offending chief.

The track, scarcely more than a couple of feet broad, winds in a succession of sinuosities through dense, impenetrable forest, so dense indeed that any flanking parties are an impossibility, and although every man of the force realizes that the enemy will have cut parallel roads and firing-places, invisible from the track, yet it is out of the question to attempt to deny him access to them. 
The troops march as closed up as the path permits-to be exact, their formation is single file, as no broader formation is possible between the walls of matted vegetation whieh shut in the winding path on either hand. The advance and rear guards are at an interval of only about fifteen paces from the main body - they are the head and tail of the winding serpent of men, which crawls through the primeval forest in gigantic loops and curves, till at times head and tail almost unite. At the head of the main body marches the Collector. A lifetime in Africa has saturated him with the lore of the bush-fight; he has nothing to learn from the professional soldier who heads the rear-guard. Soaked with the heavy night dew, the column moves forward in silenee, for the silence of the forest has the power of impressing itself upon all who penetrate its solitude. A scanty trickle of sunshine filters in from gaps in the interlacement of branches overhead. Green, damp, and silent, the forest seems a thing alive, insidious, and full of subtle menace.

Suddenly with a warning shout the officer leaps aside, a grey something flies singing through the air, glides over his shoulder, and buries itself in the throat of the man behind him, who without a groan sinks in a heap to the earth. The arrow has struck him full in 


\section{NANDI-KABWAREN-NGONGO BAGAS}

the "Adam's apple," and the iron point, with broken shaft, is protruding under his right shoulder-blade. Instantly the air is full of humming, buzzing streaks of grey, as clouds of arrows are launched from the dense greenery on either hand at the winding column. In the thirty yards of path visible in front, before it takes its next turn, two more men are down, while a third is plucking and twitching at the arrow that transfixes his right arm. The threatening silence is broken as the troops, turning right and left, open fire point-blank into the wall of bush before them, while from the head of the column down its entire length the rippling wave of rifle-fire, followed a moment later by the "pup-pup-pup" of the Maxim, announces that the attack has been general. In three minutes it is all over. The arrows have ceased, and the enemy, soundless and invisible as they have been, show no further sign of their existence. In that three minutes' fight with an unseen foe, four men have been killed outright with barbed-ironheaded arrows, two wounded, and one more, his face ashy grey in an agony of terror, exhibits a graze on his forearm and the weapon which inflicted it-an arrow with a plain hard-wood head, copiously daubed with a black tar-like substance-poison. Ligatures are hastily applied, a hypodermic injection of 
strychnine. All to no purpose-in five minutes the man is dead. "Fresh poison," remarks the Collector grimly-" had one through the sleeve of my coat," and shows an identical weapon and the hole in his coat-sleeve.

What effect our fire has had on the enemy we cannot tell-unseen he has come and gone, and left us five good men the less.

What need to pursue the story? How, carrying the wounded and dead on blanket litters borne by porters, the column winds its way, enacting similar tableaux till the final picture of all. A steep nullah falling to the ford of a swift-running stream, where, arrowheralded, comes a charge of spearmen from the shrouding vegetation. Of men with spearblades standing out a foot between the shoulders, of arrows drinking life and instilling poison, of bullet and bayonet wounds, till a stray bullet lets out the life of the hostile chief, and how his death brings submission and the Sirkari's punishment on the murderers.

I have narrated the story of a typical imaginary raid to try to show that the obsolete, mediæval bow and arrow are perhaps not as innocuous as one's imagination is prone to conceive them. The details of the little expedition have every one of them occurred in absolute fact, they have been merely taken one by one from perhaps a dozen of such expedi- 


\section{NANDI-KABWAREN-NGONGO BAGAS}

tions, and, to avoid for obvious reasons the history of any one particular raid, strung together as a type. Every incident is substantially true, and has been set down as it in fact occurred.

To get back to my muttons, viz. the bow and spear, I am not ashamed to own that a flight of poisoned arrows-the touch of which mcans probable death, launched point-blank in silence by invisible foes from the shelter of impenetrable bush-or a rush of savage spearmen, either springing from the silent darkness of a moonless night on to the thorns of the zeriba, or leaping from dense cover on top of the marching column, causes my nervecentres to tingle in a fashion quite beyond my control-especially when it is all over, and one has time to think what might have happened. And I fancy that most men who have experienced either or both events will agree with me, though I don't expect my bête noir, the pro-cannibal-or-anybody-else-who-fightsEngland, to do so.

The short time which I spent in Nandi Fort on this occasion, beyond the few expeditions which were graced by the name "Rigorous Police Operations," were only noteworthy for the transfer of the companies of the K.A.R., there and at Kericho, from the 4th Uganda Battalion to the 3rd East Africa Battalion, 
the whole of the territory garrisoned by them having been some time previously transferred from Uganda to the sister protectorate.

Shortly after my transfer to my new battalion, I was moved to Nairobi, its headquarters, then a considerably larger place than on my previous visit. During my six weeks' stay I purchased the first pony I ever owned in Africa, a Gulf Arab rejoicing in the name of Hassan. At the end of six weeks I was sent off to take charge of a newly established post in the Kabwaren country, some seventeen miles from Nandi Fort, which I occasionally visited by way of diversion, since, as I was the only white man at Kabwaren, and as the shooting there was nil, my own society hung somewhat heavily on my hands. Some six miles off was an American Quaker Mission at Kaimosi, on the border of the Nandi and Kavirondo countries. As I had come out on board ship with some of the missionaries, it felt quite like meeting old friends to stroll down and call upon them, and I was always assured of a hearty welcome. Dr. Blackburne, their medical man, used to come up and amplify my somewhat scanty knowledge of the pharmacopoia, and deal with my more complicated cases of sickness. In those days every white man was his own and his subordinates' doctor, as the medical pro- 
fession were few and far between. It was wonderful what cures one's rough-and-ready treatment effected, and how quickly one picked up a pretty comprehensive knowledge of the commoner types of disease met with locally. I usually shied off surgery if possible, although I have had to open many abscesses, etc., and once had to take off a big toe, which, however, was pretty nearly off before I tackled it. When there chanced to be a doctor about, I have often been pressed into service as a most unwilling assistant, but I never acquired a taste for surgery, unlike some men I know. I could mention a Collector who removed a jaw with only a carving-knife, and two subalterns who amputated a leg, the patients in both cases living; but then the African nigger takes a lot of killing. Fortunately I've never had from force of circumstances to take on a big operation. To get back to Kabwaren, I fancy that the missionaries were pretty glad to have my commando handy, as during a recent disturbance in the Kabwaren district an American visitor to the mission had been killed by Nandi. However, even with my various excursions and visitors, life at $\mathrm{Kab}-$ waren was pretty tedious, despite untoward incidents such as the old Sudanese lady who came up with a party of my men from Port Florence, my supply depot whence came 


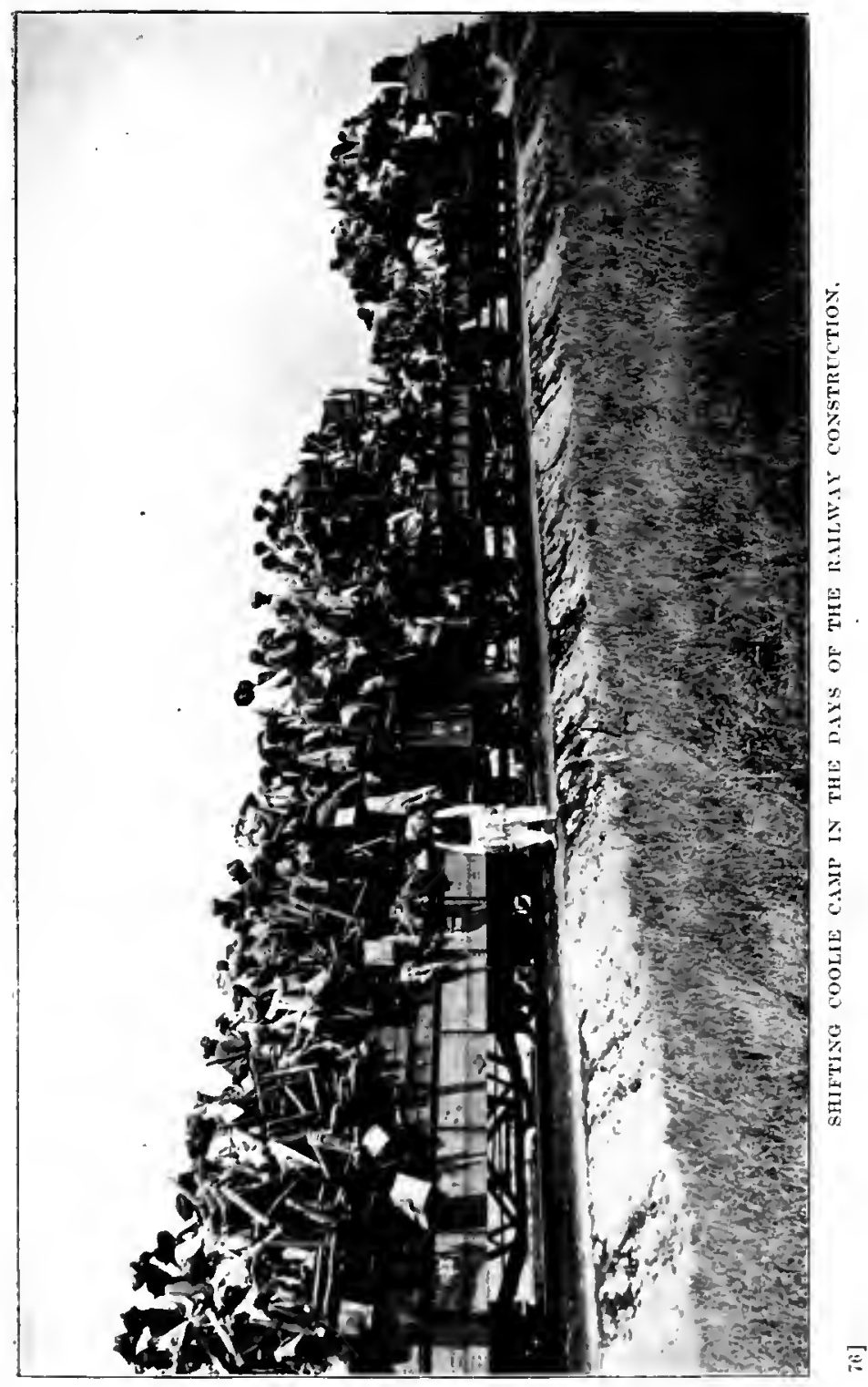



stores, men's pay, etc., etc. The good lady brought with her a large store of " marissa," and the first intimation I had of her presence was finding about three-quarters of my company-who were as bored as I was-drunk on parade. From this effect I traced the cause, and found the ancient dame, full of money, some fifty-five rupees, which I promptly confiscated, intercepted a further supply of marissa for which she had sent down to Port Florence, and poured it into the " boma" ditch in front of her anguished eyes, and finally shipped her off with her ill-gotten gains to the Collector at Nandi, who was the nearest local representative of the civil power, and the last $I$ heard of the ancient dame was that she was an occupant of the ladies' side of the local clink for infringing the liquor laws.

I was, as may be imagined, not sorry when after about two months of Kabwaren $I$ was recalled to headquarters at Ngongo Bagas, some miles outside Nairobi, where the battalion had gone into camp, lending their barracks to the 2nd Battalion, who were returning to Central Africa after the Somali campaign, and were getting familiarized with British East Africa, as it was intended that they should afterwards be quartered there.

After about three weeks at Ngongo Bagas, my company was sent off under myself, with 
Mr. Hope as Political Officer, to try to round up a section of the Loita Masai who had been giving trouble. In East Africa the law of the Medes and Persians, which changeth not, decrees that under no circumstances may a military officer undertake any armed measures without the sanction of the civil officer in charge of the district, and that a civilian must accompany every punitive expedition as Political Officer. Without going into the muchdebated question as to the good and bad points of the Political Officer system, may I here venture to record my opinion that in operations on as small a scale as those in East Africa the Political-who as a general rule is a man of experience and knowledge of the native-while perhaps not an absolute necessity, is on the whole a distinct acquisition, and, where the number of white men is limited, one extra is frequently a godsend. In all my experience in Africa I have always found that the Political and myself almost invariably saw things in a precisely similar light, nor have $\mathrm{I}$ ever heard of serious disagreements between the military commander and the Political Officer. In small affairs, especially where the military officer is frequently rather junior, and not accustomed to independent command, two heads are very frequently better than one, while the reverse may be the case in hostilities on a 
larger scale, where the tried and experienced soldier in command may be most severely hampered by the action of a Political Officer who may, possibly without in the very least intending it, and with the very best intentions in the world, act as an almost unsurmountable drag on the wheel.

However, this is no place for the airing of opinions as to the potentialities for good and evil of the Political Officer. Let me then return with all speed to our camp at Ngongo Bagas-more shortly known as Ngong-and take up the pursuit of the Loita Masai, which, more to bring to an end a discursive and possibly somewhat dogmatic chapter than from any intrinsic merit of its own, shall have the honour of opening a fresh one. 


\section{CHAPTER VII}

\section{CHASING THE LOITA MASAI}

"I LEFT Ngongo on September 22, 1904, in command of a patrol composed as follows:

2 Europeans (Mr. Hope, Political Officer, and myself).

1 Native Officer 3rd K.A.R.

75 Rank and File No. 3 Coy. 3rd K.A.R.

13 Masai Elmoran.

1 Maxim Gun.

3 Signallers, 1 Corporal and 3 men Escort to signallers. Porters for above.

"My orders were as follows :

1. To explore the country on the Guaso Nyiro in the direction of Sussian.

2. To ascertain the whereabouts and numbers of the Loita Masai, and to endeavour to recover from them some cattle recently looted by them from the Lumbwa."

So commenced my official report, the original of which lies before me as I write, and as I glance at it, a thousand minor details of each day, unrecorded in the official report or in 
my more voluminous diary, come vividly back to my mind.

At the risk of being tedious, $I$ intend to draw somewhat heavily on my diary, and go rather fully into this route we followed, as I think that it would be an ideal shooting-trip, starting from either Ngongo or Naivasha, and going on to the big buffalo-swamp on the Guaso Nyiro near Lake Natron. It was country that, up to the time I left East Africa, was quite unknown, and it was most admirable shooting country.

To do the trip comfortably it would be as well to construct a food depot somewhere near the old camp of the Anglo-German Boundary Commission; where a store of food for porters, etc., could be waiting for one's arrival, and which could be replenished from Nairobi by parties using the shorter route, via Lake Magadi and Ngong.

"1st Day.-Leaving Ngong at 7.30 a.m. we marched in a N.W. direction, arriving at the top of the Kedong escarpment, east of Mount Suswa, at midday. The road down the escarpment was exceedingly rough, being very steep, and covered with loose stones. Reached Kedong River at three p.m. and camped. Once at the foot of the escarpment in the Rift Valley, the country was flat and parched; very dusty, with a prevalent hot east wind. Lots of the commoner varieties of game, but 
the country is a game-reserve, the Kedong River being its boundary.

" 2nd Day.-A short march, as the porters were very done from the day before, when they did not get in until 6.30 p.m. Marched only $3 \frac{1}{2}$ hours (exclusive of halts), and camped on the north base of Mount Suswa. Water had to be carried, as none nearer than Mau foothills on opposite side of Rift Valley. Country open grassy plain; very hot and unpleasantly dusty. Lots of zebra, Coke's hartebeeste, Grantii and Thompsonii.

" $3 r d$ Day.-Five hours' marching took us to a stream called the Wykay, in the Mau foothills. This stream runs into the ground, and water is only obtainable near its source. Lots of game."

From a shooting point of view the sportsman's best plan would be to do these last two marches as one, if necessary halting a day at the Kedong River to rest his retinue, if the first day's march has cooked them.

Time should not be wasted on shooting, as only the commoner varieties of game are met with, and the all-important thing is to find water to camp on. Lots of Masai guides knowing the country could be got at Nairobi or Naivasha. The best time for this shoot would be in the dry weather-about September, when I did it, as in the rains it would be uncomfortably wet and game would be hard to come at, since the country is under water, 
and the game has countless drinking-places, especially near Lake Natron, where the plains are flooded by the Guaso Nyiro.

" 4th Day.-From the Wykay through the Seloita hills, covered with short English-looking turf and clover, to camp on the Narangere River. Short march, lots of common game, and any amount of buffalo and rhino tracks. Very short march.

"5th Day.-Shortish march to the Benin River, which, like the Wykay, runs into the ground. The only water near at hand. Lots of game, but rather wild, owing to the presence of a considerable number of Wanderobo. Country to north and west hills covered with dense forest in which I imagine there are a lot of buffalo. To the south hilly and scrubcovered.

" 6th Day.-A march of three hours in a southerly direction brought steeply downhill out of the hills on to a gently sloping plateau. Then turning westwards we crossed a large, open plain, then into very thick scrub, and following a dry nullah we descended a very steep gradient and reached the Kisabi River after about seven hours' trekking. 'The Kisabi was then-the height of the dry season -about twenty-five feet wide, and full of fish of the barbel type. The country we passed was intersected with numerous precipitous nullahs, running into the main nullah of the Kisabi. These nullahs would probably be impassable in the rains. $\boldsymbol{A}$ fair amount of game, especially ostriches, and any amount of rhino spoor, also elephant and buffalo.

"Just as we got down to the Kisabi things 
were livened up by Hope almost falling over a lion in the long grass. Of course, after carrying our rifles all day, we had handed them to our respective gun-bearers while we negotiated the steep descent to the river, and equally of course the said gun-bearers had chosen this particular moment to fall back to the tail of the column, so friend Leo departed pursued by nothing more deadly than a shower of stones.

"The same evening I had the misfortune to get overtaken by darkness while out shooting meat for the caravan, and leading the way back at the head of a meat-laden crowd of orderlies, etc., I contrived in the black darkness to walk over a ten-foot cliff, alighting with a severe bump on the rocks below. I fortunately wasn't damaged, but my double 450 snapped at the pistol grip and left me without a heavy rifle for the rest of the trip.

" 7th Day.-A five hours' march, in a southerly direction, down a slight grade, brought us to the junction of the Guaso Nyiro and Kisabi Rivers, above which junction we camped. At this time of year-the height of the dry scason-the Guaso Nyiro, below its junction with the Kisabi, has an average breadth of 60 feet, and is only fordable in places; in the rains it would be impassable without a Berthon boat." About twelve months later I was encamped on the same river, close to the German boundary, and had some of the finest shikar of my life there-of which more anon.

Here we remained for eight days and did a good deal of shooting. We ought to have 
shot a species of antelope which was very common, and whieh we took to be a local variety of Grant's gazelle, and did not bother to shoot. Shortly afterwards Mr. Russell Roberts shot in the same neighbourhood a new species-Gazella Robertsi, which I am confident is the animal which we saw here.

As we were the first Europeans who had visited this spot we erected a large stone cairn on a hill-top near camp on the day before we marched away. Whether the next European who sees it will wonder who the builder was and will indulge in speeulation as to a former race, I cannot say, any more than I can tell if he will find the pair of Ross prismatie glasses which my orderly left on the top of it - presumably to mark the dignity of the occasion-and only remembered having done so. when I wanted them ten miles on our return march the next morning.

We had the rather unpleasant experience in this camp of running out of food. Meat, of course, we had in abundance, as game swarmed, but the column which was to follow us out and replenish our rice, grain, etc., failed to materialize. The troops were reduced to half a teacupful of rice per man per day, to accompany the meat we gave them, and for the last three days had no rice or flour at all. 
Hope and myself ran out of everythingexcept whisky and tobacco, by the mercy of Providence. As long as the rice lasted we had a little with our meat, and our cook ventured on rice bread, which I can't conscientiously recommend. When the rice supply ran out we were, like every one else, reduced to plain meat-even the salt was finished. I never lad any idea that meat could become so absolutely repulsive and entirely nauseatingbetween the pangs of hunger and our enforced diet the alternative was pretty equally nasty.

The cause of our waiting at this camp was the shortage of food, as we daily expected the food safari to turn up. However, as we could not go forward for fear of losing it altogether, and as things were rather unpleasant, we decided to retrace our steps, doing double marches on account of the famine. The second march we met the long-expected safari wandering about the country in a casual kind of way, and I still cherish the remembrance of a tin of Bath Oliver biscuits which the mess steward had packed away among my stores.

Although we did not meet with the Loita Masai in force, we ran across a few individuals, to whom we gave instructions-to be passed on to the tribe-that the raided cattle were to be taken in at once to Nairobi or Naivasha, 
and that the headmen of the tribe were to accompany them. These orders were complied with beforc our return to Ngong. The Loita, being a nomad race with no fixed abode, had no difficulty in keeping out of our way for the short time we were out. Wc were continuously watched by their scouts. However, our little expedition effected its object, and we incidentally mapped a considerable amount of unknown country.

As I have said before, I have rather dwelt on this trip with a view to aiding intending sportsmen. Our route is marked on the map at the end of the volume, and it can be seen that from our last camp the Guaso Nyiro has only to be followed to bring one down to the old Boundary Commission Camp by the big buffalo-swamp, one of the finest shooting countries in Africa. It should not be forgotten that lower down the Guaso Nyiro the river becomes the boundary of the gamereserve, and shooting is only permissible on the right bank.

About a fortnight after my return from this trip I was once more on trek, this time to join the Anglo-German Boundary Commission, which was then delimiting the boundary between British and German East Africa. 


\section{CHAPTER VIII}

THE ANGLO-GERMAN BOUNDARY COMMISSION

Tre nine months which I spent on the AngloGerman Boundary I shall always look back upon as perhaps the most interesting period of my life. Although I was alone-i.e. as regards white men-for a considerable part of the time, yet the shooting was so magnificent, and the study of wild animal life so enthralling, that I think I rather preferred my own society to that of any one else. For I held then and still hold that to get the best sport a man should shoot by himself: by which I mean that he should make his shooting expeditions alone. Two men shooting from the same camp-although they would of course normally go out apart and in different directions-are apt neither to enjoy nor appreciate their sport to the full. There are so many things against them. The game is twice as much disturbed as it otherwise would be, and each district is worked out in a correspondingly shorter time.

Then luck steps in, and undue success on 
the part of one is apt to lead to jealousy and all kinds of worry. Even apart from shooting, two Europeans by themselves find many points of friction. Leaving out questions connected with sport, there are very few men with whom one can spend a couple of months alone, without quarrels more or less serious-more especially in a tropical climate and without the luxuries of civilization. Personally I can only think of a very limited number, and I well remember having a terrible squabble with one of my very best friends-apropos of absolutely nothing-after a couple of months alone together. A certain amount of fever was enough to put us both on edge, and a right royal row was the result. Therefore I would say : "Shoot alone: and if you can't do that, be very careful in choosing your companion."

I left Nairobi in October 1904 with orders to take over command of the escort to the British part of the Boundary Commission, consisting of a company of the 3rd King's African Rifles, of which I was taking half with me. The Commission had previously been at work in Uganda for-as far as I remembera couple of years, and had now crossed Lake Victoria, and were starting work in British East Africa. With my party I trained to Port Florence, and thence marched in a westerly direction. After traversing thickly populated, 
but somewhat uninteresting, country, we arrived in due course at the Commission Camp on the Mara River, where I found orders awaiting me from the British Commissioner, Captain Smith, R.E., to stand fast and push up food-supplics to the advanced camps.

At this point, I think, it would be as well to make a digression-possibly a somewhat lengthy one-and, before proceeding with my own expericnces, to give a brief account of the co-operation of our German colleagues and ourselves in fixing the boundary between the two protectorates. The European personnel of the British Commission consisted of three officers, a medical officer, two officers on duty with the escort, one N.C.O. in charge of porters, and three Sapper N.C.O.s : the German Commission was approximately the same. Of these numbers three officers and the three Sapper N.C.O.s were appointed by the Foreign Office to perform the technical work, the remainder were supplied by the local administration, and their work had little or nothing to do with the actual fixing of the boundary.

When Great Britain and Germany divided between themselves the large slice of Eastern Africa which they now hold, the boundary between these possessions was determined in Europe by the statesmen concerned. It followed no natural features, and was in fact 
merely an arbitrary line drawn with reference to degrees and minutes of longitude, only deviating from its rigid straightness when Mount Kilimanjaro was reached. Then the line diverged eastwards so that the highest mountain in Afriea might be entirely ineluded in the territory of Germany. Now although it was the simplest matter in the world to draw this boundary-line on a map, and thus to show the dividing line between British and German country, yet as a matter of practical politics no one had the vaguest idea of the actual ground whereon the boundaries of the two countries lay. Some years previously a provisional boundary had been marked out on the ground from the coast to Mount Kilimanjaro by an Anglo-German Commission, but there were doubts as to the accuracy of this marking. Not that the matter was of any pressing urgency, since the major part of the ground through which the boundary ran was uninhabited. The object of the present Commission was to apply the imaginary line from the map to the actual ground, and to mark out, so that all men might see, the actual line between British and German territory. This had necessitated, before operations were commenced in Uganda two years before, a very considerable amount of work. The nearest point whose geographical position had been 
accurately fixed latitudinally and longitudinally was a stone pillar in Zanzibar, which had been erected by the Navy in a survey many years back. However, all this preliminary work had been finished long before I joined the Commission.

In addition to laying out the boundary a detailed survey of the adjoining country was being carried on, and our modus operandi was somewhat as follows-and I fancy that that of the Germans was similar. In advance of every one went a party under one of the officers of the escort, whose duty it was to build upon prominent hills and features large beacons, visible for a considerable distance in every direction. These beacons were used by the survey party as points upon which to take bearings in the triangulation, and their exact latitude and longitude were carefully worked out. Accurate information of this was furnished to the German survey party, working independently on their side of the boundary (whose position, though not yet fixed, was easy to deduce approximately) and they in their turn kept us informed as to the progress of their survey. Thus each survey party was enabled to provide an independent check upon the work of the other.

Some three days' march in rear of the beaconbuilders came the theodolite survey. This 
consisted of two parties, each under a Sapper officer, working independently at a triangulation of the country, and comparing their work by cross-checking. Three or four days' march behind them again came the three Sapper N.C.O.s. Each of these had a frontage of five miles, which he mapped by means of a plane table survey. They were, of course, furnished with all the fixed points obtained by the theodolite parties in front of them. They worked in parallel lines and thus furnished a detailed map of the country fifteen miles inwards from the boundary-line. By the aid of this map, and with the latitude and longitude of every important geographical feature exactly determined, it was an easy matter to mark out in the ground the actual boundaryline. And so in rear of the plane table parties came the British and German Commissioners, who, furnished with all information from both Commissions, marked out the boundary with large stone cairns, so placed that from any one the next in each direction was visible. Checking was frequent, and, to provide an additional check and to ensure absolute correctness, occasional halts were made in country where a suitable base was obtainable, and the position was checked by astronomical observations.

Such, briefly stated, was the method of 
work, and as each of us had his appointed place, it followed that we saw very little of each other, and still less of our German colleagues, unless a British camp on our side of the boundary happened to hit off fortuitously a German camp across the line. This, however, seldom happened, and in my nine months on the Commission I met only two of the German officers. Such excellent fellows were they that it was a matter of great regret to me that I was unable to see more of them. The relations between the British and German Commissions were excellent. There was no friction, and the greatest amicability prevailed officially, and the greatest cordiality and goodfellowship privately and individually.

One had a certain amount of opportunity of observing the German system of administration and the relations existing between the white officials and the natives. To English ideas many of their mcthods may appear at first sight unduly harsh and repressive, but on reflection I am not at all sure that this is so; and even if the balance is inclined a trifle too much to the side of severity, it is by no means certain that this is not a less grave fault than the tendency of British rule to incline in the opposite direction. A discussion, however, on such subjects lies entirely outside the scope of these sketches. Such German officials as I 
had the good fortune to meet during my stay in Equatoria were men keen on their work, taking a deep interest in the native races under their charge, good linguists, and conscientious gentlemen. It is the fashion among a section of Englishmen to sneer at the administrative efforts amongst coloured races of any other nation except our own. Granted that we have been infinitely more successful than any other nation, we have nevertheless not yet reached that pinnacle of perfection from which we can truly proclaim that we have nothing to learn from the methods of other Powers.

From the above brief summary of the procedure of the Boundary Commission it will be seen that the Commission was by no means a compact body. It was in fact strung out over several hundred miles of country. Since the country which we were traversing was practically unknown and entirely uninhabited, it can easily be comprehended that the question of rations for the large native establishment of servants, troops, and carriers was an extremely important one. The porters were entitled by the terms of their agreement to a "kibaba" ( $1 \frac{1}{2}$ to $2 \mathrm{lb}$.) of flour, rice, or beans per day, in addition to whatever meat might have been shot by the European with themthis latter a luxury. The troops were similarly circumstanced. 
The procedure followed was to establish food-depots or bases along the line of march, from which food was supplied to the various camps. Karungu, a station on Lake Victoria, in an inhabited and administered district, was selected as the first depot, and had been filled up with bags of flour and rice, which were. being transferred to the Mara River Camp by safaris plying between the two places. The outlying camps sent parties into Mara River Camp for their food-supplies, and other safaris were emptying Mara River into Ndasegara, the food-base in front, from which the more advanced parties drew their rations.

In the meanwhile a party had been pushed on along the route to be followed, in order to build yet another depot on the Guaso Nyiro River in the Great Rift Valley, and to fill it with food from Nairobi, which camp (Guaso Nyiro) was to act as our supply depot on the journey between itself and Kilimanjaro, where we again touched inhabited country and got into easy communication with the railway. As a matter of fact this arrangement had to be modified later on, and yet another depot constructed at El Donyo Erok, which was filled from Kiu Station on the railway. A glance at the map will show our great dispersion. At the time when I joined at the Mara River our advance parties were in the Rift Valley and 
our rearmost food-depot was at Karungu. We were thus strung out from the Guaso Nyiro River to Lake Victoria Nyanza.

It can easily be seen, therefore, that the question of supply and transport was, as it usually is, an urgent one. Although we had a certain number of donkeys, they were much slower and less satisfactory than porters, and although their use to some extent meets the difficulty of food-supply, the disadvantages of frequent sickness and deaths, as well as their slowness, more than counterbalance this advantage, especially when the transport is on a large scale and time is of value. We were thus compelled to employ porters as our main means of transport, and the number of these was very considerable, to cope with the large amount of transport. Since the more we employed the more food we needed, the matter in reality moved in a vicious circle.

In these circumstances my duties as O.C. Escort were therefore permitted to lapse, more especially as my command was scattered in small parties over some hundreds of miles, and adequate supervision was therefore an impossibility, and I remained at the Mara River Camp to supervise the receipt and despatch of rations, in fact, to fulfil the duties of Base Transport Officer. These duties were not of a particularly arduous description, and I 
managed to fit in a lot of shooting here, as the camp was situated in one of the most magnificent game countries $I$ have ever been in. A striking feature of this camp was the enormous number of marabou storks. They used to sit in rows all around the outskirts of the camp, their red heads and slatey blue bodies, picked out with white, affording quite a striking colour-effect when viewed from a distance.

The camp was pitched on a high bluff on the left bank of the stream, which at this point was sufficiently broad and deep to necessitate the use of a Berthon boat for crossing it. On the right bank the country was rolling downland, with a certain amount of scrub and patches of forest and jungle. On the left bank, hills, covered for the most part with forest, rose from the river, eventually forming a high plateau, the highest point of which was some ten thousand feet above sealevel. In the open country were to be found lion, leopard, roan antelope, topi, hartebeeste, impala, water-buck, wildebeeste, warthog, and many other species of game, while in the hills buffalo and rhino. also existed. It was in very truth a hunter's paradise, and here for a month or so I enjoyed to the full that free and open life which can be experienced only in the lonely places of the earth, where, alone with nature, man's primeval instincts, un- 
hampered and unclogged by the artificialities of civilization, come to his aid in his daily conflict with the instinct of brute creation.

I was entirely alone, with the exception of my fifty or so black retainers, comprising my personal servants, carriers, and a small escort of soldiers. For several months I did not see a white face or hear a word of English, but my black followers were such exccllent fellows, as indeed the negro unspoiled by civilization almost invariably is, that $I$ felt no craving for any other society. My daily routine was somewhat as follows : Four o'clock a.m., a cup of tea and a hasty toilet; 4.30, departure from camp in order to be on the shootinggrounds at dawn (six a.m.), far and away the best time for shooting. Arrived at my destination, I would search for the particular animal or species which I had beforehand decided to pursue. If successful in finding, the stalking (in which lies the chief joy of the sport) and sometimes-not always-the kill followed. Perhaps, in the course of the search, I would come across a fresh species or a fine herd of a kind alrcady obtained, when I would forsake my original object and pursue the new quarry. By the time my victim had been stalked, shot, and broken up, it would be high noon. Then a drink of water, a pipe, and a couple of hours' sleep in the shade of the 
nearest tree, passed the hot hours of the day, during whieh shooting is at its worst. Then, about 2.30 p.m., I would bend my steps in the direction of the camp, shooting any desirable trophy met with en route, or having a turn at feathered game with a scatter-gun. Back at camp at 5 or 5.30, a hot bath, dinner, my one meal in the twenty-four hours, and to bed at 6.30. Such was my life, living on the produce of rifle, gun, and rod, and a more healthy, exhilarating, and fascinating existence I defy any one to adduce.

The wonderful beauty of the scenery, the glorious climate, which compares favourably with that of the Riviera, the glory of the African sun in its rising and setting, the continual communion with nature, and the daily study of the thousand varieties of animal life, their habits and ways, crowded into each day more of interest and delight than could a year of life in cities. Often I would spend an entire day without firing a shot-not from lack of opportunity, for game was evcrywhere, literally in thousands-but because unnecessary killing is to my mind a crime against nature. To me a day is every whit as happily spent in observing and studying the myriad habits of wild creation, without once using my rifle, as is one in which $I$ have the luck to bag one or more good trophies. It should be 
the hunter's maxim to kill most sparingly. Two good heads of a species are enough for any man, though one will in fact probably shoot more. A good rule is, never, except for meat, shoot anything carrying a smaller head than your best of that species. If this rule be followed it will be found that one gets far more interest and real pleasure from the observation and study of game than if one spends the days in indiscriminate butchery.

To turn from generalities to facts, and to get off my particular hobby, let me try to describe a day which I had at Mara River Camp. I had arrived just before daybreak at the locality where I intended to shoot. I had to obtain meat for my entourage, as food was getting low, but beyond that I was not out after any particular species. As I stood watching the east lightening up with the birth of day, I could hear all around me the cries of the omnipresent animal world-the shrill chirp of the cricket, the deep bass note of the bullfrog, the harsh, grating call of the guinea-fowl, and the strange, long-drawn-out wail of the hyena, while over all rang out, impressive and majestic, the deep-throated roar of the lion, telling the listening world that the king of beasts was making his homeward way after a night's successful hunting. Through the lessening mists of early dawn, 
dim shapes were seen on every side, as the antelope and gazelle made their way toward their watering-places and grazing-grounds.

As the sun's first rays flashed out I could see the broad plain stretching for miles on every side, teeming with animal life, until in the distance the drab mists of morning shaded off the clear-cut outlines into one universal mass of greyness, tinged with the rosy glow of dawn. I made for a line of low hills about a mile distant, where $I$ hoped to find a herd of roan antelope that frequented this locality. Twenty minutes' sharp tramp, soaked waist high by the dew-sodden grass, when a " Hist!" from my Somali gun-bearer told me that his keen eyes had sighted the game. True enough, there was the herd, six cows and a fine old bull with a magnificent head. Unfortunately they had sighted us first, and, as we paused, off they went, and in a moment were lost to sight in the straggling bush that surrounded us. We followed the spoor until it led us across a ridge somewhat higher than the surrounding undulations, and here I called a halt. I wished the roan to have plenty of time to settle down and get over their alarm before we approached them again, and their spoor was as plain as a book to read.

Accordingly I seated myself upon a fallen tree, lighted a cigarette, and, taking out my 
glasses, scanned the surrounding country. To the left a continuous line of brilliant verdure and stately trees marked the sinuous course of the Mara. In front the undulating prairie, dotted with table-topped mimosas and acacias, was literally peopled with game. An enormous herd of topi, some three hundred strong, was grazing undisturbed almost within a stone's throw. Farther off a large herd of wildebeeste were stampeding across the plain at their curious lumbering gallop, probably alarmed by lion, while everywhere the dainty Thompson's gazelle added an element of sylphlike grace to the scene. I marked the roan moving slowly away at a walk, stopping every now and then to snatch a mouthful of luxuriant grass. Their fright was almost forgotten; they would not go much farther.

I turned and scanned the country to our right, where the blue of the Lumbwa hilltops showed dimly above the misty horizon. Everywhere there was game-mile upon mile of smiling country covered with grazing herds. However, they were all of the commoner varieties, and I was about to close my glasses preparatory to following the roan, when my eye was caught by a tree, about a mile away, literally covered with vultures. Closer inspection showed more vultures and numbers of the scavenging marabou storks perched 


\section{THE BOUNDARY COMMISSION}

upon every bush in the vicinity. This could signify only one thing-the presence of carrion -in all human probability the carcass of a dead animal. Further, the fact that the birds were not engaged upon their meal pointed to the fact that the presence of something else was keeping them away; ergo, probably lions were on their kill. The roan may wait! There is nobler game afield!

Leaving a man to keep an eye on the movements of the roan, I, with the rest of my entourage, consisting of two gun-bearers and ten carriers for bringing in such meat as I might kill, started for the bird-covered tree. Arrived within a quarter of a mile of it, I left one gun-bearer and the carriers ensconced in some thick scrub, and taking my $\mathbf{2 5 6}$ magazine Mannlicher, I went cautiously forward, accompanied by my other gun-bearer, carrying my double 450 cordite rifle. Stealthily we pushed forward, up wind, through the open scrub, peering in every direction for a glimpse of our quarry. Soon we were within a hundred yards of the tree, and still there was not a sign of anything. Suddenly from our right front came a low, deep "woof." There were, then, lions afoot! Bent almost double, we crept noiselessly forward, every sense alert, every sinew braced, every nerve tense ; then suddenly we both dropped simul- 


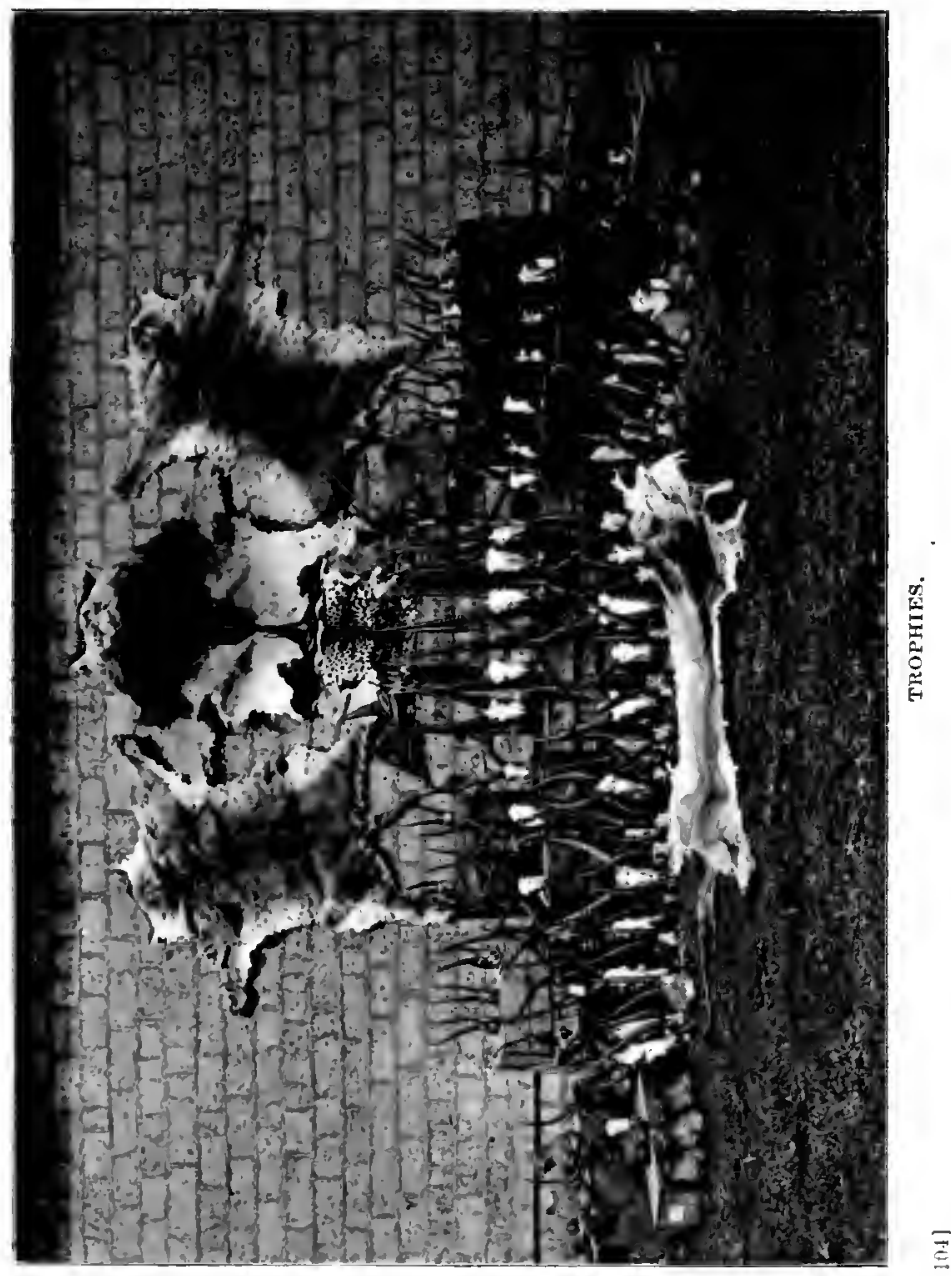



taneously, flat to earth. In a slight depression, twenty-five yards away, lay the mangled body of a cow giraffe, and on and around it were no less than seven lions, or, to be more exact, two lions and five lionesses, all full-grown. They were feeding slowly, their first hunger being evidently appeased, and were pushing and jostling one another playfully, their low growls and loud purrings being distinctly audible.

For a couple of minutes I waited, watching them, then, as the biggest lion, a fine, blackmaned fellow, turned sideways to me, I raised my Mannlicher and let drive at his neck. I heard the thud of the bullet on flesh, and he dropped in his tracks like a stone. With a simultaneous growl every head went up, and the lions swung round, facing the noise of the shot. I let fly a second bullet at the chest of the second male, and with a deafening roar, he bounded high in the air, dashed a dozen yards forward, and fell dead to earth just as I was drawing a bead on him afresh. The remainder, all lionesses, turned at my second shot and walked slowly away with much tail-lashing and a chorus of growls. I was just in time to get a snapshot at the hindmost as she disappeared into the scrub. The "tell" of the bullet and her answering snarl told me that I had hit her, which bloodspots on the leaves confirmed. As we stood 
undecided for a moment as to following her up, my gun-bearer suddenly touched my arm, and I saw four of the lionesses disappearing over a low rise in front. Only four! That means that the wounded one is somewhere in the patch of scrub. Following up a wounded lioness into thick bush is somewhat jumpy work, so, taking my heavy double-barrel, I cautiously followed up the blood-spoor through the scrub. Suddenly from close in front came a growl, and I caught a glimpse of the wounded beast moving off, a glimpse so momentary that a shot was impossible. We still followed the track until it emerged from the bush into a small open glade, surrounded on every side by scrub. We were halfway across, still following the blood-spoor, when the bushes on the far side rustled, and automatically my rifle went to my shoulder. Out she came, without a sound, her tail straight in the air, evidently meaning business. Straight for us she came with great leaping bounds; my right barrel spoke, and the bullet slewed her round as it hit her far back in the ribs. An infinitesimal check and on she came again, but this time my left barrel caught her fair in the chest. Her impetus carried her forward, and, spouting blood, she dropped, dead as the proverbial mutton, not ten paces away. Quite as near as was pleasant. 
Three lions in ten minutes was pretty good for one morning, but there was still meat to be got; so, having got off the skins and sent them back to camp, I returned to the hill-top and took up once more the pursuit of the roan.

In about an hour we came upon them in some broken, shady ground, and twenty minutes' stalk, literally ventre à terre, brought me behind some long grass within twenty yards of them. By this time they had all laid down for their midday siesta, with the exception of one cow who stood sentinel. With glasses glued to my eyes I watched them for some twenty minutes, devoting special attention to the spot where a big pair of horns above the grass denoted the position of the bull. At the end of that time the sentinel cow lay down and another took her place. Then, taking a line along my rifle towards the bull, I gave a long, loud whistle. In an instant the whole herd was on its feet, the next it was dashing wildly away, the bull with a softnosed bullet planted behind his shoulder. $\mathrm{He}$ faltered a second, swayed, and was down, and in another moment my Somali gun-bearer's knife was at his throat; for, unless an animal is " hallaled," no Mohammedan can touch its

1 To " hallal " is to kill by cutting the throat. All animals killed for food by Moslems must be killed in this manner, as the Koran lays down. With game, etc., or an animal shot, 
flesh, and all my caravan were disciples of the Prophet. The head measured 30 inches, so my pocket tape showed me, which is quite good for this part of the world, and my best up to date. After the animal had been broken up and despatched to camp, I took a couple of hours' sleep, and then, at about 2.30 p.m., started homewards, bagging en route a fine impala for my own table and a hartebeeste to complete the rations of my caravan.

After a stay of some weeks at the Mara, we had succeeded in getting all the provisions and stores pushed forward to Ndasegara, for which place I then set out, leaving with much regret the camp where I had spent so many happy days.

the law is considered to have been complied with if there is any movement left when the knife is at its throat and if blood flows immediately on the incision being rade. 


\section{CHAPTER IX}

THE ANGLO-GERMAN BOUNDARY COMMISSION (continued)

The journey from the Mara River to Ndasegara, via the camp of Kibaibai, where I saw the unaccustomed sight of a European, Dr. Chevallier of the Commission, was noteworthy to me only for my first sight of eland, and for my cook giving me a very elaborate dinner with tinned plum pudding on December 26, under the impression that it was Christmas Day ; and, indeed, it's hard to keep one's dates right out in the wilds.

Ndasegara was about as unlike the Mara River as any two places well could be. It was a high point on a stretch of rolling, open downs, about ten thousand feet above sealevel, at times most abominably cold and covered with " Scotch mist." Mara River, on the other hand, was low-lying and thickly wooded. The shooting around the actual camp was nil, and one had to go back along the Kibaibai track for some miles before one came to shooting-ground. However, when one got there the shooting was pretty good, there being 
a lot of lion, rhinoceros, and eland about, as well as Roberts' gazelle, which I unfortunately took for ordinary Grant's gazelle, which they very much resemble, and did not shoot. My regret may be imagined when $I$ afterwards heard what I had missed, especially as I never had another chance at this extremely local animal. It was while shooting from Ndasegara that I had my experiences with lion recounted in the chapter entitled, "Leaves from an African Game-Book." I was not altogether sorry when I got my orders to push on to the main camp on the Guaso Nyiro River, as I had about exhausted the shooting potentialities of the surrounding district, and I had heard stories of the extraordinarily good shooting in the Rift Valley.

The march between Ndasegara and the Guaso Nyiro was only noteworthy for a missed lion, lots of fresh buffalo-spoor, the steep climb down the escarpment, and the complete scattering of the safari by two rhinoceros. This happened on the open plain near the Guaso Nyiro River at daybreak-an early start having been made. I was justly punished for my laziness in not carrying a rifle on account of darkness, by not getting a shot at one of the best rhinos. I've ever seen. It was really a rather peculiar experience. The first charge took place while it was dark, on 
the tail of the caravan, and when daylight arrived I saw the whole of my safari dotted over the plain, discarded loads everywhere, one of them containing my rifle-cases, every small thorn tree bearing a strange fruit of porters, and amid the debris two rhinoceros fussily marching about. Before I could work my way round to my jettisoned rifles the rhinoceros had taken their departure.

The months which I spent at the Guaso Nyiro Camp were, I think, the most fascinating from a shooting point of view that I have ever spent. The plains on either side of the stream fairly swarmed with game-amongst which were some enormous "heads" of the common species as well as some varieties-such as Waller's gazelle and Oryx callotis-that I had never before encountered. The river itself was bordered on both banks by dense bush which fairly. swarmed with buffalo. I made a number of expeditions into this thick stuff, but without success-it was so thick and tangled that the buffalo could always hear one forcing one's way through, and although I have been on several occasions within ten yards or less of a buffalo, the impenetrability of the branches prevented me ever seeing him -the first intimation I had of his presence being the noise of his flight. In addition to the risk of getting involved with a stampeding 
herd, the absolute futility of this procedure made me give it up. My next effort was to march a considerable distance up stream outside the bush, carrying with me a Berthon boat--then cut through the bush to the river, launch the Berthon, and float down stream to camp. Not a sign of buffalo, though both banks were cut up with their tracks. It was most annoying, with all these quantities of buffalo about, that one could never get a sight of one. Captain Dickinson of the K.A.R., who, like myself, had put in many vain efforts to get at the buffalo, and I then joined forces, and after several unsuccessful efforts eventually marked down a very big herd and discovered their daily, or rather nightly, routine.

A couple of miles or so down stream from our camp was an enormous swamp several miles in extent, bordered by the customary belt of scrub. Our herd used to pass the day in the swamp-whose thick ten or twelve foot reeds made pursuit a matter of considerable difficulty and danger, but at night came out to feed on the open plain beyond the scrub, into which they retired before dawn; then they used to spend an hour or so in this scrub before returning to the swamp. A few efforts to walk them up in the scrub not only convinced us of the uselessness and danger of this method of proceeding, but 
showed us that the herd when alarmed always stampeded back to the swamp. This fact determined our next move in the campaign, which was to build a couple of perches, otherwise platforms, on poles about twelve or fourteen feet high, a couple of hundred yards apart, at the junction of swamp and scrub, where the growth was a little less dense than usual, and in the track of the herd's usual route to the swamp. A little clearing somewhat enlarged the field of fire from each perch. Having allowed two or three days to elapse to remove the scent of man, we took up our positions on these perches one morning before dawn.

Of all the various species of big game that abound in Central Africa, the buffalo is perhaps the greatest prize that rewards the efforts of the sportsman of dangerous game: elephant, lion, and rhinoceros, are all, it is true, greatly to be desired, but they are all, in a greater or less degree, widely distributed and fairly accessible. The buffalo, however, although his numbers are increasing fairly rapidly after the scourge of rinderpest which swept like a wave through Africa some few years since, is still comparatively rare, and even when he is to be found, has usually taken up his quarters in swamp or forest so impenetrable, or ground so difficult, as to make his pursuit a matter of extreme difficulty 


\section{THE BOUNDARY COMMISSION}

as well as of considerable danger; for the wounded buffalo is generally acknowledged to be, with the possible exception of the elephant, the most vindictive and dangerous animal that exists in Africa.

It is a well-known fact that the wounded buffalo will hunt his pursuer as a terrier will a rat, and will do his best, so long as strength remains to him, to equalize matters by giving as good as or better than he has got.

And here let me insert a word of advice to the sportsman in his first encounter with buffalo: Never, as you value a whole skin, follow the track of a wounded animal into thick cover; for he invariably and without fail will, after having gone forward a certain distance, double back parallel with and close to his track, and, concealed in cover, await his pursuer following his spoor, with probably disastrous results for the said pursuer; since the short, sudden rush of a beast endowed with enormous vitality, his horn-protected head held low and covering his chest, is by no means an easy thing to stop at a distance of, say, six paces. So, if you can't get him out by driving or by firing the patch of bush, go in by another track and try to work round to him, but don't, if you can possibly avoid it, just follow up his blood spoor.

Taking into consideration the rarity of and 
the danger involved in the pursuit of the buffalo, to say nothing of the magnificent trophy he forms, I think that I am not exaggerating when $I$ say that he is the prize of the sportsman in Africa.

However, to turn from generalities to facts, I will try to give a brief description of our morning's sport with buffalo which I think has hardly been equalled during an experience of several years' big game shooting in various parts of the world.

Just a word as to the mâchans: each consisted of four stout uprights sunk into the ground and braced with crosspieces, on which, at a height of about 14 feet, was erected a small platform of branches about 6 feet square, large enough to accommodate two people without difficulty.

On these two mâchans Dickinson and I accordingly seated ourselves, each accompanied by one gun-bearer, and awaited the arrival of the beaters, who were timed to commence operations at six a.m., we having estimated that we should arrive at our positions at about 5.30.

I was on the left-hand mâchan, Dickinson on the right; and I must confess that, as I sat waiting for the drive to commence, I was feeling quite despondent about our chances of success, as just as we were arriving at the 
mâchans, we had put up two or three buffalo which dashed into the thick bush with a great fuss and clatter, and I feared that they would cause the whole herd to stampede in some other direction.

However, my depression was very soon dissipated, as, almost immediately, I heard the report of one of the beaters' Martinis, quickly followed by a snorting, rushing, and crashing of broken branches, and four bull buffalo dashed into the open belt close to Dickinson's mâchan ; the next sound I heard was a report, quickly followed by a second, from Dickinson's double 400 cordite, the "tell" of the bullets, and the crash of a shattered bush as a fine bull bit the dust between the mâchans and the swamp, uprooting the grass and ploughing up. the ground in his death agonies.

I had been unable to get a clear view of the buffalo, since they passed close to Dickinson's mâchan, concealed from me by the low scrub which lay between us, and had therefore not fired, and now sat on my perch, cursing my luck, and more than ever convinced that the morning's sport was over for good and all, and that my own miserable share in it was nil, until another quarter of an hour had elapsed, when a sudden and furious fusillade from the beaters was followed by a second stampede from apparently the same patch of bush, and 
five cows appeared, going at their clumsy gallop, this time, to my renewed disgust, to the right of Dickinson, who, having secured his bull, made a desperate but unavailing attempt to kodak them.

I have said that I was more or less disgusted, but my disgust was as water is to wine compared with the unsurpassed fury of my Somali gun-bearer, who sat beside me using the most lurid and unprintable language-fortunately in his mother-tongue.

We both had the pleasure, and it was a pleasure-though at the time I regarded it with very mixed feelings-of watching for the next three-quarters of an hour the buffalomostly young bulls, cows, and calves-coming out in threes and fours like driven partridges, and hugging Dickinson's mâchan as a stormstricken ship hugs the sheltering shore, never once giving me a possible shot-that is at anything worth bagging.

However, all things come to him who waits - if he waits long enough-and at last just as Mahomed Adan-my Somali-was approaching bursting-point, two cows and what I took to be a fair bull dashed across an open space about 150 yards to my right front. I let fly at the latter with my right barrel, and felt that indescribable thrill that only the big game hunter knows when he 
hears the thud of the bullet telling on flesh; the three swerved abruptly to the right, and came straight down between the mâchansthen suddenly halted for a moment, all the time hidden by bush, came on again, again stopped, giving me a snapshot at what I thought was the back of my bull, to which, alas! no answering thud responded, and were away into the swamp, where, once thoroughly under cover, they immediately pulled up.

"Ha!" thought I, " there's a dead bird there," and my drooping spirits went up with a bound. "All I've got to do is to give you time to stiffen a bit and then wade in and secure you "; and so thinking, turned on my mâchan to wait for more to come along, which however was just what they declined to do; with the exception of a snapshot at a rapidly moving back in high grass about 250 yards away, which I missed handsomely, I didn't fire another shot that morning.

Not so my fortunate friend Dickinson, to whom, in the next three-quarters of an hour, the buffalo flocked in an cqual proportion to that in which they shunned me, and who, at the end of that time, had two more bulls with three bullets apiece in them, lurking coyly in the swamp, where there were now a considerable number of unwounded, and two others slightly wounded by Dickinson. 
Then there ensued half an hour of calm, at the end of which I told Mahomed Adan, who had been worrying me to let him follow up my victim into the swamp, to go across with a message to Dickinson and have a look for blood-spoor on the way. He delivered the message and had entered the bush between us on his way back, when I was horrified to hear a snorting grunt, a crash of breaking bushes, and a rifle-shot, and to see a cloud of dust rising from the place where I judged him to be. Just as $I$ was starting down from the mâchan to go to the rescue, I saw from the movement of the bushes that the buffalo, for such it was without a doubt, was moving back into the thick belt of bush. Almost at the same moment I heard Dickinson shout "The man's up," and a moment later I saw a blood-stained, dust-begrimed figure stagger out of the bush towards my mâchan.

I sat, every nerve in tension, covering the advancing figure in case of a second rush, but to my intense relief nothing more happened, and the unfortunate Somali regained the mâchan without further accident.

I was enormously relieved to find, on examining him, that he had had an almost miraculous escape, as beyond a severe shaking, he was unharmed. He was an old friend and ally of mine who, in former tight places, had 
proved his unflinching pluck and unshaken nerve, but in my opinion he now more than ever proved it ; and I think that the majority will agree with me when I say that his first request was to be allowed to return and bring back his rifle, a Rigby Mauser of mine that he was carrying and had dropped, and from the fact that from first to last, when the buffalo tossed him and returned to gore him on the ground, he never uttered a cry.

I, who had seen nothing beyond the dust and the moving bushes, learnt what had happened from himself and from Dickinson, who saw the whole affair, but was unable to fire, for fear of hurting the man.

On his return from Dickinson's mâchan Mahomed Adan had seen heavy blood-spoor, and then noticed a buffalo in the bush lying on its side apparently quite dead; he approached to investigate, and, convinced that it was dead, did not put in another bullet. When he was about three yards off the brute got up and charged; he got in one shot, and then turned and made for a clearing, trying to gain time to reload as he went, but was caught and tossed almost the next instant-just as he had gained the clearing, and in full view of Dickinson, who, of course, was unable to fire, as the buffalo was right on top of the man when he saw them. As he was tossed 

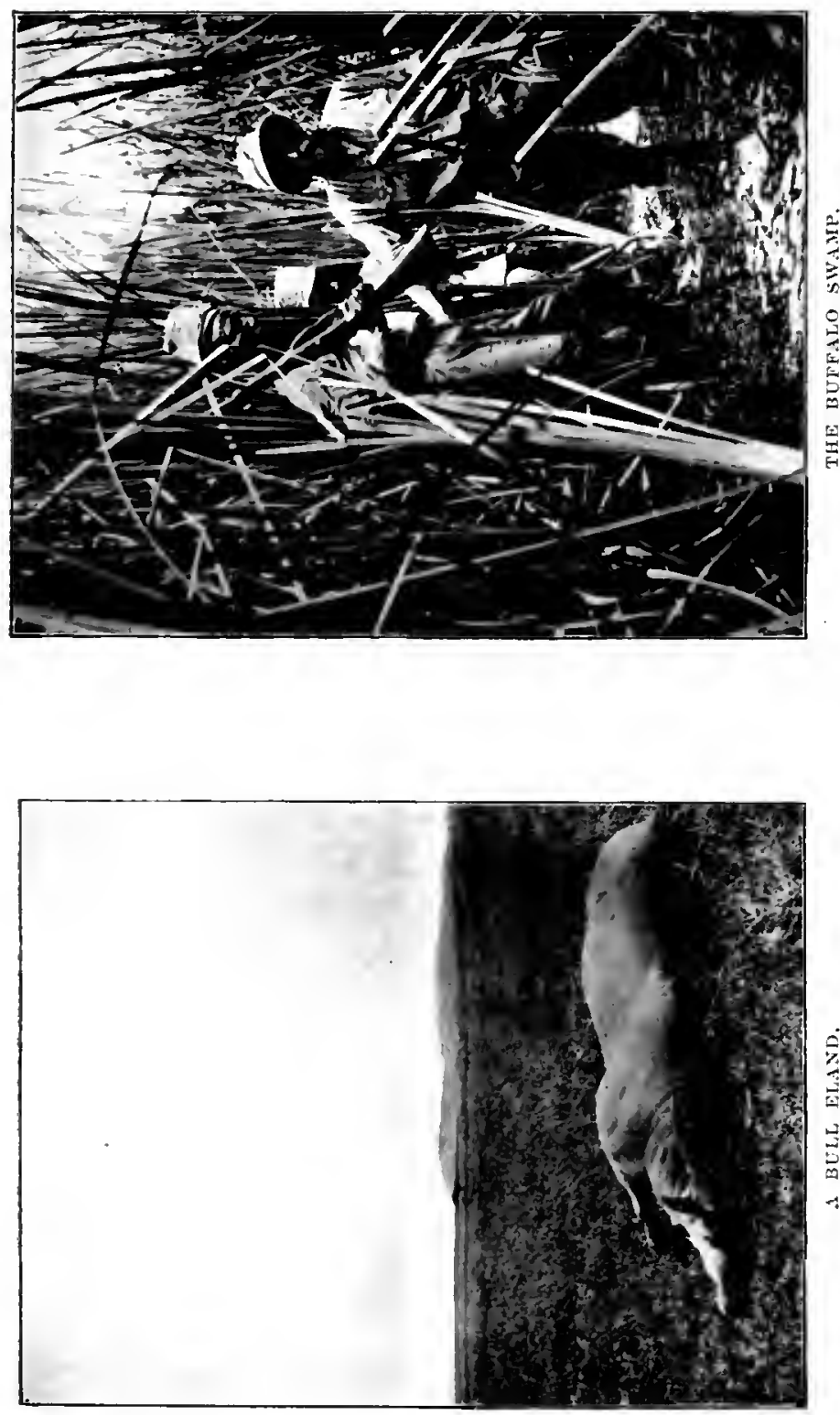

空 

Mahomed Adan dropped his rifle and held on to the beast's horns with both hands; he was thrown up, and more or less slid over the animal's back on to the ground, and the latter turned away, but came back and tried to gore him as he lay, fortunately, however, only hitting him with his head and doing no damage with his horns; the buffalo then retreated into the bush. The blood which had so alarmed me was that of the buffalo, which was very hard hit and in a dying condition; indeed, had it not been so, Mahomed Adan had been a dead man. As it was, by the most marvellous good fortune he escaped practically unhurt.

Almost immediately afterwards the beaters arrived, advancing together along a path through the bush, and I made them fire a volley into the particular clump of bush into which, by its movements, I had marked down the buffalo. As this produced no movement, we advanced cautiously and found a big cow buffalo lying dead, her attack on Mahomed Adan having been her last expiring effort. She turned out to be the one I had shot in mistake for a bull, which had dropped and stayed in the scrub while both Dickinson and I thought she had entered the swamp with the other two. She had lain absolutely motionless and silent within 50 yards of Dickinson's mâchan for nearly two hours, with other 
buffalo charging past her, and frequent shots fired close to her, waiting for something tangible on which to wreak her vengeance.

The one most fortunate shot from my -450 cordite that had hit her had entered behind her right shoulder, passed through her lungs, and lodged in her neck, making a fearful wound; had she been less severely hit, she would undoubtedly have killed Malıomed Adan, since without doubt she meant misehief, and his bullet had done very little damage, entering the lower part of the chest and missing all the vital parts.

This ended the morning's sport, and I think all our feelings were those of intense relief at the fortunate termination of what might have been a tragic disaster.

On reading what $I$ have written, it appears to me that a few words of explanation are needed to make more definite certain points.

In the first place, the men whom I have described as beaters were not so in the strict sense of the word, since the bush was so dense and impenetrable, and the game so dangerous, as to render beating in the ordinary way quite impossible and out of the question.

The men, ten in number, armed with MartiniHenry rifles, first extended along the open feeding-grounds at the edge of the bush and fired a few shots into the air. The line of retreat of the buffalo being almost a certainty, 
greatly simplified matters. When the outer edge of the bush was clear they entered in a body along one of the buffalo-tracks and moved slowly through the bush towards the swamp, extending a little when possible and periodically firing-of course into the air. By this means they gradually cleared the bush in front of them, driving the buffalo into the swamp.

Secondly, lest this mode of shooting should be deemed unsportsmanlike, I may say that what I have termed clear ground was only so relatively to the thick bush, and that, as a matter of fact, high up as one was, one could only catch fleeting glimpses of the buffaloor portions of them-and as they always were moving at a gallop, straight and quiek shooting was essential if one wished to bag anything. Further, a drive was the only practicable method of ever getting a shot in country of this type, as we had found by trying to walk up our game on several occasions, and to have had them driven up to us standing on the ground would simply have meant that one was selecting a rather painful and not particularly sporting form of suicide, absolutely inevitable had the buffalo come out together in any number, since the bush, in the thinnest parts, was well over a man's head-the average height being about twelve feet, besides being absolutely impenetrable to a man in most places. 


\section{THE BOUNDARY COMMISSION}

Even in a mâchan one was by no means safe, as a determined charge by a single buffalo might easily have carried away the whole concern, and, had a large herd stampeded towards it, only extremely straight and rapid shooting could have given one a chance of turning them and avoiding an unpleasant and messy exit from this vale of tears.

However, enough of explanations, lest it be said, "Qui s'excuse s'accuse."

To return to actual facts. After finding my buffalo, we inspected Dickinson's first bull which he had knocked over outside the swamp, and a fine beast it was. We then held a council of war as to following up his wounded ones into the swamp, but after Mahomed Adan's accident none of us were very keen about it except Mahomed Adan himself, who was all for going in; I don't believe he knew what fear meant.

However, as the swamp was full of unwounded but angry buffalo, as well as the wounded and still angrier ones, we decided against pursuit, and made for camp, where we arrived for breakfast at eleven a.m., feeling rather pleased with ourselves.

One of Dickinson's buffalo, a good bull, we found just inside the swamp the next day, and secured after a series of alarms and excursions; in addition to two other bullets 
in his interior, he had had his left shoulder smashed into a pulp by a bullet that had entered through his ribs on the right side, which had prevented his travelling any distance ; one other, which we were guided to by hyænas three days later, was a small bull very much mangled and eaten by lions and hyænas, and his horns so destroyed by maggots as to be worthless. Two others that he had wounded slightly we never found, and they are probably alive and hearty at the present minute.

The total result of our drive, therefore, was two good bulls to Dickinson, to me the cow I shot in mistake for a bull, which was an exceptionally large one, both in bodily bulk and as regards her horns, which are, I believe, the second largest on record, and quite the largest that have been shot in this part of Africa, so that I consider my mistake quite a pardonable one.

To give some idea of the strength and impetus of a charging buffalo I may mention that we discovered the road taken by the main herd on their first alarm; they had gone along inside the thick belt of bush and entered the swamp about a mile to the right of Dickinson's mâchan : they had tramped out, through solid and impervious bush, a road broad enough and flat enough to drive a pony and trap along, the branches and leaves that 


\section{THE BOUNDARY COMMISSION}

they had trampled down being trodden into the earth and ground into a sort of pulp.

I consider that this was perhaps the finest morning's sport that it has ever been my good luck to take a hand in. Judged by results, perhaps the bag may seem a poor one-three heads to two guns; but the heads are buffalo, which counts for something. Though I personally fired only three shots, yet the tense excitement, the anxious waiting for the game to break cover, the glimpses of the magnificent brutes crashing through the scrub, to the accompaniment of rending branches, snorts, and rifle-shots, and above all the spice of danger, madc this morning, to me at all events -and I think that the big game hunter will understand my feelings-one of those times when one feels that life is indced worth living, when one sees nature face to face, one wonders at the sheer strength and vitality of brute creation in all its naked vividness, and one feels that in after years the picture of the morning by an African swamp, with the indescribable reek of the marsh, the blazing sun overhead, the crashing charge of the buffalo, and the ringing crack of the cordite, will be printed indelibly on one's mind, a memory of the time when the blood ran hot in one's veins, and when one lived in very truth. 


\section{CHAPTER $\mathrm{X}$}

THE ANGLO-GERMAN BOUNDARYNAIROBI-MOHORONI

Of the remainder of the Boundary Commission it is hardly worth while to write at any length, as the country between the Guaso Nyiro and Kilimanjaro is game-reserve, both on the British and German sides of the Boundary, so that a description of its shooting potentialities would be merely tantalizing to those who are unable to shoot there.

As regards the Guaso Nyiro Camp, the river forms the boundary of the game-reserve and shooting is only permitted on the right bank. Nevertheless, even with this restriction, it is, or was when I knew it, one of the finest shooting grounds in the country. Elephant, lion, leopard, buffalo, rhinoceros, Oryx Callotis, Waller's gazelle, and eland, are obtainable in the vicinity, as well as the commoner varieties, such as Grantii, hartebeeste, wildebeeste, impala, reed-buck, water-buck, etc. The site of the Boundary Commission Camp 
was some miles above Lake Natron and Mount Shomboli, on the left bank of the river, in one of the few places where the banks are clear of jungle. It can be reached, traversing shooting country all the way, as described in Chapter VII, or by a more direct route through the reserve via Lake Magadi-no shooting of course being permissible. I have done the march to Nairobi by this route in three days, but that entails pretty hard marching, and four or five days are more usual. Using donkey-transport and making a food depot at the Guaso Nyiro, which could be filled up from Nairobi, an excellent shoot could be done without much difficulty, going back along the tracks of the Boundary Commission, and finishing up at the German port of Sherati on Lake Victoria.

Travelling in the other direction the Rift Valley is waterless, and sufficient water has to be carried to last to Lanjoro Diss, a distance of two marches. Lanjoro Diss is a spring amongst the hills just on the German side of the Boundary, and is the nearest water to the Guaso Nyiro.

There are said to be greater and lesser kudu in these hills, and certainly it looks very like kudu country. The Rift Valley itself is hot and feverish, in striking contrast to the highlands on the Lake Victoria side, which to my 
mind are some of the finest country in East Africa.

From Lanjoro Diss to Laitokitok, the site of the Boundary Camp on the lower slopes of Mount Kilimanjaro, there are no difficulties as regards water, except that there is occasionally too much of it. It is the Nyika, a wonderful game country, and well described in Schilling's books. From Laitokitok to the British border station in Taveta is an uninteresting march, but from Taveta to Voi, on the railway, there is a good road, lots of game, but no waterwhich latter has to be carried, and the marches accordingly hurried. At Laitokitok I left the Boundary Commission with the very deepest regrets. It had been a most pleasurable period-not the least charm of which had been the cordial relations between British and Germans. A more cheery soul than the German Commissioner, Hauptmann Schlobach, I never wish to meet, and I fancy every member of the English Commission will retain many memories of what the genial Hauptmann was wont to call "a strong night" spent in his company.

At the commencement of June 1905 I found myself in Nairobi with half the Boundary Commission escort, which had been reduced on arriving at comparatively civilized parts again. After my long and continuous " bush 
service " I was rather glad to get back to civilization once more. Nairobi was just then very cheery, and full of visitors for the July races. These race meetings (then two a year) were the occasions for dances, dinners, cricket matches, and general dissipation, Nairobi being full of "those on pleasure bent" from outstations, and the universal genius of African hospitality had full play. Fircd by the prevailing cheeriness $I$ invested a portion of the money which had accumulated, despite myself, during my absence from civilization in a couple of racing ponies, or rather a pony and a horse, at the end of the meeting. The pony, in whose ownership I formed one of a syndicate, we were afterwards lucky enough to sell for what we gave for him. When I last heard of him he was a lady's confidential trapper. The horse did me extremely well later on. After a delirious six weeks or so I was suddenly shot off once more, at two days' notice, to my old location, the Nyando Valley. The Nandi, it appearcd, had onee more been at their old games of cutting up all and sundry, and in consequence of two or three railway coolie gangs having been "scuppered" work on the railway was at a standstill.

Opinion in general favoured a "show," as since the Nandi Expedition in 1902, which ended more in favour of the Nandi than in 
ours, they had gone on their own sweet way. The Home Government-or at least such was the story current in the country-had forbidden a punitive expedition on any grounds whatsoever, with the result that when the Nandi committed any more than usually unruly act, the mode of procedure adopted by the luckless officials on the spot was to summon a mceting of the chiefs conccrned. Sometimes they came, sometimes they sent representatives, sometimes they did neither; in which latter case the matter slid unostentatiously into obscurity. If, however, the official was lucky enough to collect any of them they were solemnly fined so many head of cattle, which were seldom produced, and told to be good boys and behave themselves. Small expeditions there frequently were under the ægis of the Collector of Nandi-an officer with a wonderful influence and authority over the unruly tribesmen, and whose method of administration evoked their respect-but anything on a larger scale than these so-called "Rigorous Police Operations" was emphatically taboo.

On the present occasion, however, it was currently believed that the Governor, the late Sir Donald Stewart, had determined to teach them a lesson. In the event this view proved correct. However, at the end of August, 
when I was sent off post haste with my company to Mohoroni (where Lord Kitchener has since purchased an estate) no official pronouncement had been made, and we were employed in garrisoning the railway stations, picqueting the line, and providing escorts for the coolie gangs from Lumbwa to Kibos. Two companies were thus employed, with Mohoroni as the headquarters of the troops.

The state of affairs was rather curious. Martial law had not been proclaimed, though at every station, at every gang-hut, and along the entire length of the line were troops for the protection of the railway employees against armed attack; yet no official enemy existed, and it was a matter of great difficulty as to what orders should be given by the white officers to their men. Matters were brought to a head by the following incident: Two soldiers in company with a coolie gang encountered three or four Nandi elmoran (warriors) in fighting kit. The two soldiers were Masai and could talk the Nandi language. They hailed the Nandi and asked them what they were doing. The Nandi made no reply and moved off. One of the soldiers followed them, shouting that they must accompany him and come before the "bwana" (white officer). The rearmost of the Nandi turned and threw a spear at him; he ducked to avoid it, 
and his companion, thinking that he had been hit by the spear and fallen, fired and killed the Nandi. The body was brought in, together with the spear, and the story taken down by the white officer in charge of the line. All the coolies of the gang told the same story. The matter was of course reported to headquarters, with the result that, mainly on the initiative of a certain judicial officer, orders were issued for the trial of the soldier by a civil court on the charge of murder. Needless to say there was considerable feeling aroused, which was not lessened by the reported remark of the judge who was to try the case, that the man was guilty of murder and should be hanged. Whether the judge did in reality ever give expression to these views I am not in a position to say, but there was a consensus of opinion that he had done so, and as there was no question of a jury in a case of this nature, it can be imagined that the military officers on the line were not best pleased.

Most of them, including the C.O. of the prisoner, had ordered their men to refrain from any acts of aggression, but to protect the gangs, etc., to defend themselves, and to bring in to headquarters suspicious persons or gangs found on or near the railway. Here was a man who had done no more than obey his 


\section{THE ANGLO-GERMAN BOUNDARY}

orders being tried, and standing apparently an excellent chance of being convicted of murder. Were the situation not so serious it would have been irresistibly comic, not to say Gilbertian. Fortunately the Governor, who had been on tour at the time of the incident, on his return ordered the charge to be withdrawn. The man was brought into court and the charge formally withdrawn in consideration of a sum of money being paid as compensation to the dead man's relatives. This sum was paid, so far as my memory serves me, by his company officer.

This incident shows the trend of mind of a certain class of civil official-mainly drawn from the ranks of the legal profession-to whom all things military are abhorrent, and to whom a state of existence in which civil law has for the time to give way to the hard arguments of battle, murder, and sudden death, is not only abominable, but inconceivable. It is an attitude of mind which residence in England, with the ever-present, well-ordered routine of civilization, does much to foster, but as a rule a certain period of residence on the outskirts of Empire, where law and order are often represented by the will of the strong man armed, frequently tends to broaden this cramped and obvious view of the cosmos. We, more than most nations, are inclined to 
shudder at the sound of the word militarism, and to exalt civil law to a position little lower than that of the angels. This possibly may be a fault on the right side, but that in practice it works out at all events-unfairly, the following two instances go to prove. Both occurred in a district under military governance so far removed from the seat of Government that to obtain a reply to a letter-telegraph there was not-sent in the swiftest manner possible, was a matter of several dayspossibly of weeks.

There is in existcnee in these regions an ordinance that no military officer-though he be in civil charge of a district or province, as were the two men whose stories I am relating-may undertake any warlike operations without sanction from the civil authorities.

In each case it was a matter of sudden opportunity-time for sanctioning authority there was not. In the first case a punitive expedition had just been concluded, a fine of cattle had been levied, the fine was being openly laughed at, and not only were the tribesmen announcing that they did not intend to pay, but there were signs of fresh troubleas usual a weak policy had encouraged revolt. Suddenly came news that drought necessitated a change of pasture for the cattle of the tribe. 
To reach their new pasturage a certain route was essential on account of water. The officer in civil and military charge saw his opportunity. Hard, rapid marching brought him at the head of a force to a certain water-hole where the entire cattle of the tribesmen were collected, with the result that the fine was paid and the tribesmen, with the fear of a strong man in their hearts, went back to good behaviour.

As a result of making a warlike expedition (though I believe not a shot was fired), the officer in question was officially informed that he need never hope to obtain command of his battalion-and it was only the shuffle of a change of Government removing a certain Secretary of State from a particular department that secured it for him.

Secondly, a brilliant series of forced marches brought a British force at daylight one day to the camp of a number of hostile tribesmen under the banner of a holy man preaching a holy war to a daily increasing congregation of followers. A short, sharp fight, and the death of the holy man scattered his disciples. Result-a severe reprimand for offending against the above-quoted ordinance-and a lctter of thanks from the foreign Government whose territories march with ours at the scene of the conflict, for having by promptness and courage 
averted what might have been a dangerous and formidable war. So much for the rigid adherence to a form of government transported from civilization to the wild places of the earth. 


\section{CHAPTER XI}

THE NANDI EXPEDITION, 1905-6-NAIROBI

After a few uneventful weeks at Mohoroni news came along that a punitive expedition had been decided on, as the Nandi had refused to make any reparation for past offences, being, I imagine, under the impression that this was merely the usual Government "bluff." There was great rejoicing at the tidings, but it was quickly followed by news which brought universal sorrow, namely that of the death of Sir Donald Stewart, who had succumbed to an attack of pneumonia, brought on by a wetting consequent on duck-shooting at Naivasha. A fine sportsman, a firm friend, a strong man, and the finest Governor that East Africa had ever had, he possessed the confidence, respect, and friendship alike of the official and nonofficial residents of the country, and his untimely death was a severe blow to the prospcrity of the country.

The news of his death cncouraged the Nandi in their recalcitrance, as the chief 
Laibon or medicine man-the virtual ruler of the tribe-gave out that he had by his magic arts killed the chief of the white men. Another incident which confirmed the Nandi in their unyielding attitude was the removal of the Government station of Soba, in the Nandi country, to Lumbwa, which was taken as a proof of fear, and Sir Donald Stewart's successor, Colonel (now Sir James) Hayes-Sadler, from the neighbouring protectorate of Uganda, decided to maintain his predecessor's policy of a punitive expedition. The mobilization of troops and collection of Masai levies was carried on at Nairobi and Naivasha, and the Nandi were warned that on a certain date the days of grace would expire. Accustomed to the usual policy of the Government, they regarded the two companies on the railway as the whole strength of the punitive expedition. However, they were quickly undeceived. Under cover of night a train landed a company of troops at Kibigori station, whence they marched to Nandi Fort, and were for the whole of the following day concealed in the lines of the company stationed there. A night march of this force culminated in the surprise and death of the Nandi Laibon early the next morning. Immediately after dark on the evening of the Laibon's death, troop-trains commenced to arrive at Mohoroni and Lumbwa 
stations. Daybreak the next day saw some 1,200 rifles, with a proportion of Masai levies, advancing into the Nandi country from these stations, from Eldama Ravine, and from various points along the railway. The suddenness of the attack, together with the death of the Laibon, unfortunately, from our point of view, appeared to paralyse the Nandi, and instead of the determined resistance which had been anticipated, the enemy's sole aim appeared to be to save themselves and their. cattle by flight.

As the Nandi had a great reputation for bravery, and had on many previous occasions fought with extreme gallantry and determination, their present attitude was a complete surprise. During the whole course of the expedition, which lasted over a period of several months, there was never any attempt at organized resistance on a large scale. There were, it is true, many small skirmishes, but the enemy could never be brought to battle in anything approximating large numbers, and the whole expedition devolved into a guerilla warfare of ambushes and surprises of small parties. Eventually, by dint of occupation of the country by a chain of fortified posts, by the capture of flocks and herds, and by the destruction of crops, the Nandi chiefs camc in, and the tribe was removed into a 
reserve away from the railway line. As a fighting race and an obstacle to progresswhich they had been for so many years-their power was broken.

From the foregoing it must not be imagined that there was merely a peaceful procession through the country, killing Nandi when any were seen. There was plenty of fighting on a small scale. Patrols were cut up. Columns were ambushed and attacked in thick bush, but the enemy never attempted to mass his forces and attempt hostilities on a large scale. This was probably due to the absence of a paramount authority over the various chiefs and their sections, consequent on the death of the Laibon.

It was, as a matter of fact, no picnic for the troops engaged, and after nine strenuous months on the railway and in Nandi, concluding with a spell of small-pox camp, my company -and its commander-were pretty glad to see Nairobi again, even though we left several of our members under the soil of Nandi.

Nairobi at this time I always shall consider as the best station in which it has been my lot to serve. A fine climate and every sort of sport made life there a very pleasant thing. Shooting, both big and small game, polo, pigsticking, a pack of hounds, race-meetings, and of course cricket, tennis, and the like, together 
with the luxuries of civilization, all added to the pleasures of existence. The influx of settlers brought a welcome civil element to leaven the unmixed official society of former times. Nairobi, I understand, is now a very much larger and more wealthy and important place than it was in 1906, but I'm confident that it never was and never will be a cheerier and jollier place than it was in that year.

I acquired one or two horses and ponies, and was lucky enough to be fairly successful at the two race-meetings which $I$ attended in 1906. Racing-which has always been rather a weakness of mine-was more enjoyable to me in Nairobi than anywhere else-possibly because I did bctter, but I'm inclined to think that it was because racing was in no sense a business there. The whole thing was amateur: owners trained and, when possible, rode their own animals. There were no professional jockeys, no big stables run as a money-making concern, no bookmakers, except the amateur-whose "book" was not infrequently a curious production. The whole thing was purely sporting, the class of animals was good; the stakes were quite worth winning-and, though there were several rich men competing, the small owner was not squeezed out as he is rapidly being in India. 
No, the racing in East Africa was as sporting and as clean as on any turf in the world, and much more so than on a great number. Long may it continue and flourish.

To hark back once more to the Nandi Expedition, which it seems to mc I have passed over somewhat briefly, I personally did not find it wildly exciting-not half so much so, in fact, as many small "shows," the reports of which, if they ever got beyond the Government Offices at Nairobi, figured as "Rigorous Police Operations." The reason, as commonly believed, of this title, lay in the fact that Secretaries of State were getting extremely weary of reporting military operations in remote parts of Africa, which no one took any interest in unless the name happened to be unusually humorous. (One can imagine, for instance, Kakepōch eliciting screams of laughter either in the Commons or-the $\mathrm{Ox}$ ford.) However, these same military operations afforded excellent handles for irritating and captious members to employ in the pleasant game of Minister-baiting, as played at Westminster. Therefore (one imagines) on one hot and sultry evening a harassed Secretary of State (possibly suffering from toothache) rushes enraged from the House and cables peremptorily, "There are to be no more military operations in Africa. Never, never, 
never." The equally harassed Governor in faroff Equatoria reads the cable, tells his office desk exactly what his opinion of Secretaries of State is, calms down, and cables back: "The Wa-Lumeli have just eaten three missionaries and a lay teacher (black). The Bishop terribly upset. What am I to do about it?"

One can see the Governor's brutal bombshell falling fair in the worried Minister's dressingroom, where, in the latest mauve pyjamas he offers his cheek to the seductive lather of the shaving-brush wielded by John, deftest of valets. Imagine the poor gentleman's look of despair as he tears open the envelope and perceives the horrid dilemma. On the one hand the C.M.S., stertorous for vengeance; on the other the loud-voiced orators of the " down-trodden black brother" school, to say nothing of the professional Minister-baiter, ever alert and on the watch for opportunities. Picture the frown growing deeper on the pale, lofty brow, what time the lather-brush wanders over the square, stern chin, guided ever so craftily by John the light-handed. Picture the poor gentleman's dismay, his just and warrantable anger.

"Damn it! Damn it, I say."

"Quite so, sir," says John the tactful, recoiling from the wagging jaw. 
"Now, I put it to you, John. Here's a fellow, John, an infernal damned fellow, John -and that's the third time I've said damn this morning. Here's a fellow that I-we-the Government-the country-the taxpayer-you and I, John, we pay this fellow a large salary, a princely salary-no less than a thousand a year, one thousand pounds of your money and mine every year of his life, except when he's on leave; and all that this pestilential fellow has got to do in return for all that money is to stay out in Africa and govern. 'That's all-nothing else but that. And he can't even do that. Oh, I quite understand that you can hardly believe that any employee of yours could be so crass and inept. But it's a fact. There it is-down in this telegram. And he has the impertinence-if I'm not careful I shall swear again-the absolute, incredible impertinence to telegraph to me and ask me to do his work for him: the work that you and $I$ are spending our hard-earned incomes to pay him for doing. It's unbelievable. And all because I told him that he mustn't kill any more poor black men with his horrid soldiers. It's simply a piece of nasty spite. It's blackmail. 'That's what it is, nothing less than blackmail combined with incompetence. I never liked him, and now I know that he's an idle, wicked man." 
Followed a gasp of indignation and the silence of cogitation, broken at length by the words of John, pearl of valets.

"If I might take the liberty, sir, to make a suggestion___"

"I should be glad to hear your views-after all, he's a servant of yours."

"Then, sir, if I might suggest, I should saysend the soldiers-and a rose by any other name__-

"Would smell as sweet. John, you have solved it."

What need to pursue the subject and trace the euphonious name of "Rigorous Police Operations," conjuring up mental visions of a figure in blue, a shade more stern than common, possibly backed by a mounted policeman and even the threat of a truncheon in extreme cases? Why track down the brain that devised a title so admirable, called into existence 'twixt the smooth, soothing strokes of the gliding Gillette? When two great brains combine, why pin the credit to one? Let them divide the glory of achievement accomplished. "Twas a happy touch, and if we incline to the belief that so admirable a phrase was born in one brain rather than two, we can hardly avoid the suspicion that the brain was that of John, prince of all valets. 
I fear that I have digressed, and at so great a length that the Nandi Expedition must after all be passed (for really there is very little to say about it), and we must journey on to a fresh chapter. 


\section{CHAPTER XII}

SHIKAR

So far I have dealt mainly with service and very little with sport. My intention in so doing has been to paint to the best of my ability the life of an officer in the African Protectorates in the earlier days of their development. I shall now try to give some idea of the recreations and relaxations of the said officer. Very possibly my ideas on shooting may be out of datc. East Africa has changed and still is changing, or perhaps, I ought rather to say developing with enormous rapidity. When I left the country was only beginning to be the resort of the shootingparty from Europe or America. Professional hunters were only commencing to arrive, and the business of purveying and fitting-out the big game shooting expeditions was in its infancy. In my day walking up one's game was de rigueur. Riding it down or shooting from mâchans was practically unknown. Professional shikáris or white hunters were unthought of. One had one's gun-bearer, who 
probably was a fair tracker and knew something of the habits of game, but in the main one's shooting devolved into a contest between the man and the beast. One pitted one's wits against the beast's instinct, and the result was a very real knowledge, aequired by hard study and practical experience, of the nature and habits of one's quarry. It was, of course, possible to pump lead from a long distance into the enormous herds of game encountered, but public opinion sternly discountenanced that form of amusement, as also the production of immature heads, and public opinion in a small community was not to be lightly disregarded, especially where every man was more or less of a shikári.

The new-comer was usually instructed in the ethics and the elements of shooting by one or more of the old hands. One was taught that, apart from dangerous game, the stalking, not the actual killing, was the test of the man's worth; that any one might fluke a long shot from three or four hundred yards if he cared to risk the chance of a wounded beast eseaping to die in misery; but that the sportsman only fired when by his wooderaft or stalking ability he had got suffieiently near his quarry to make sure of killing; in other words, when his wit had beaten that of his antagonist. One learnt the unpardonableness of killing 
for killing's sake, and the unchanging law that a wounded beast must be followed and put out of its misery, regardless of time, fatigue, and any other tempting trophies encountered while so doing. I venture to think that the man who followed the unwritten law of the big game hunter, who on foot prepared to pit himself against the dangerous game, or outwit the timid, to whom the escape of a wounded animal was abhorrent, and who would as soon loose off a machine-gun in Piccadilly as open fire promiscuously into a herd of game at four or five hundred yards, is usually a pretty good man in other walks of life.

Nowadays, when the writing of a cheque in a London office is the entire work of a shooting-trip; when that magic slip of paper pays your passage, lands you, not only in Africa, but on your shooting-grounds, puts a rifle in your hands, a professional white hunter and a fully equipped caravan at your service, and even guarantees you and produces so many species and so many head of each particular species, one's knowledge of the lore of the veldt need not be vast, nor need one have acquired by the sweat of one's brow any extensive acquaintance with the habits of wild game, or what I may term the etiquette of big game shooting.

Possibly the prescnt state of affairs is better 
for the country, but it doesn't bring out many admirable qualities in the shooter, and $I$ don't fancy that the game think much of it. Personally, I rate clay pigeons in one's back yard as a considerably higher form of sport: they're a good deal harder to hit than an eland at fifty yards, and one hasn't got a mob of armed retainers to come to one's assistance, to finish off one's work, or-to take the risks in certain eventualities.

It is, as I have said before, a sufficiently hard task to find anything fresh to say in relation to shooting-the sport par excellence of British East Africa. So many excellent books have already dealt exhaustively with the subject, and so much attention has of late been drawn to East Africa by the shootingtrips of the Duke of Connaught, Winston Churchill, and Roosevelt, to say nothing of the books of Patterson, Schillings, and Dugmore, that the majority of people have a pretty good idea of the country and its fauna.

I imagine that most people-at any rate, those who have not actually shot big gameinfinitely prefer to read of the pursuit of dangerous game than the mere stalking of the non-dangerous. As regards the actual shooting, I suppose that the dangerous game is more fascinating than the non-dangerous, but I'm not at all surc, I once heard a very keen 
and well-known shikári say, "I'd rather shoot a snipe than an elephant any day." I don't know that I altogether agree with this dictum, as of all shooting, elephant-shooting has a peculiar fascination all its own. Certainly, I personally find an elephant easier to kill than a snipe, but then I'm a vile shot with a scattergun, and once one knows where to take an elephant and has got within certain killing distance, he is an extraordinarily easy beast to slay. Of course, if one doesn't slay him straight off there are apt to be alarms and excursions, and it's here that the heavy rifle proves its value.

There has comparatively recently appeared in The Field a considerable correspondence on "the best all-round rifle." In my lumble opinion there is no such thing as an all-round rifle, any more than there is an all-round golfclub. For light game one wants a light rifle, and for heavy game a heavy rifle, and in this I fancy that most men of experience will agree with me. I grant you that the very smallest effective bore, a $\cdot \mathbf{2 5 6}$, will kill anything-if you hit it in the right place. A large majority of experienced big game hunters take their first shot at dangerous game with a smallbore rifle, if thcy can get in a steady, aimed shot. It is far easier to plant a Mannlicher bullet into a small area than that from, say, a 
double 450 cordite, since the rifle is lighter, the sighting more accurate, the trajectory flatter, and the recoil less. That one shot should suffice to kill your beast, for, as I have said, a $\cdot 256$ bullet in a vital part will kill anything, and it has sufficient penetration (using a solid) to reach an elephant's brain, which is the greatest test of penetration required in big game shooting. Ninety-nine times out of a hundred the one shot does the business; the hundredth time something goes wrong - a shaky aim, a flinch, anything-and the bullet goes wide of the vital spot. The sportsman is then "up against" a wounded animal, who may or may not turn nasty; if he does, and the sportsman is dependent on his small bore, by which I mean anything under $\cdot 400$, then heaven help him! He has about as much chance of stopping the charge of leopard, lion, buffalo, rhinoceros, or elephant, especially the last three, with a small bore as he would have with a squirt. Of course, the age of miracles is not past, and he may do soif so he is greatly favoured of Providence. Mr. Jackson, the Governor of Uganda, has turned a charging rhinoceros with a twelvebore shot-gun loaded with number eight, and a rhinoceros has been killed with one shot from a pocket revolver, but I don't imagine either Mr. Jackson or the owner of the re- 
volver would advocate his weapon as the ideal one for use against rhinoceros. The only weapon that onc can rely on to stop the charge of any dangerous animal is one whose striking-power is such as to deliver a temporarily knock-out blow, whether a vital part is hit or not. Personally I always used, or at any rate carried as a sccond weapon, a double -450 cordite; with it I have stopped the charge of elephant, rhinoccros, and lion, which I think is good enough. As a matter of fact, as regards lion or lcopard, I believe that a ball and shot gun with a soft lead bullet, or a scatter-gun with S.S.G., is the ideal wcapon, but it's hardly worth while carrying a special weapon for two species when a heavy cordite will do all that is required.

As regards the bullet. The only time I have ever used solids from a $\mathbf{4 5 0}$ corditeonce I knew its capacity for penetration-was for the head-shot at elephant. For everything else and for every other shot at elephant I used a soft-nosed bullet; I used it at an elephant charging, and found that hitting him frontally in the head with it knocked him outthis not once but several times. I grant that a solid would have knocked him out equally well and might have killed him, but a softnose stopped him all right and stunned him sufficiently to allow of his immediate despatch. 
As regards anything clse, a solid gives, I think, too great penetration combined with lack of shattering-power. I have broken both shonlders of a rhinoceros with one soft-nosed bullet. I have hit a rhinoceros obliquely in the ehest and found the bullet embedded in the skin on the other side, far back in the ribs, with a hole into which one could put one's fist through his body. I have seen a buffalo raked cliagonally from shoulder to pelvis, and I am convineed that except for the brain-shot in an elephant the solid should be ignored when using a largebore high-velocity rifle.

Of course for small game the 450 is too heavy-onc can use it for the bigger antelope, eland, water-buck, wildebeeste, roan, and the like, but naturally one must earry something lighter for small antelope. After a fairly exhaustive and comprehensive trial of most varietics of rifle, I eventually settled on a battery composed of a double, non-cjector 450 cordite by Lang, a magazine '256 Mannlicher-Schoenaur by Jeflery, and, of course, a scatter-gun. 


\section{CHAPTER XIII}

\section{A DAY'S WORK}

FIve-thirty a.m. brings Athmani with the early-morning tea-tray to my bedside, to the inspiriting strains of Réveillé. By lamplight the prospect outside bed seems singularly uninviting. It is remarkably cold, and Athmani informs me that it has been raining. However, much as I may dislike the prospect of tearing myself from the blankets, it has to be done, as there is a busy day ahead. A hasty bath and toilct accomplished sees me clad in khaki in readiness for carly-morning parade, and I lift the flap of my tent-door and step outside into the banda. For the benefit of the uninitiated I may here explain that a banda is a large building or shed composed of thatched walls and roof on a wooden framework, usually divided into two compartments -the front or living room having the outer fly of one's tent attached to the interior of the roof to minimize the inconvenience of leakage, and the back division, containing the inner fly, pitched as a sleeping-compartment, ensuring 
dryness and a certain amount of warmth. Such were the palaces which to many European officers stood for "home" in the early days of my sojourn in East Africa; with a little ingenuity they could be rendered, if not precisely luxurious, at any rate passably comfortable.

Emerging from my palatial residence, I walk across the "boma," and, passing the guard-room and main entrance, come out upon the parade ground, where my dusky company is going through various evolutions with an undeniable smartness and precision under the command of the Mnyema colour-sergeant, while at the other end of the ground a squad of recruits are absorbing the elements of "right turn," "left turn," under the ægis of a young and loud-voiced corporal. A few weeks ago these have been more or less wild savages, and in a few weeks more they will be fit to take their place in the ranks, smart in appearance and turn out, and drilling in a way that would in no way discredit a British battalion. For the average African soldier loves drill and his rifle, and passing through the lines at any time of day one may see small groups of soldiers with rifles and side-arms drilling and drilled by each of their members in turn.

While on parade we may take a look at our 
surroundings. The "boma," or Government enclosure, is surrounded by a thick, impenetrable thorn zeriba, supplemented with a few strands of barbed wire run through the brushwood, and a low wire entanglement outside it. It is somewhat in the shape of the letter $L$, with the entrance, flanked by the guard-room, in the re-entrant angle, and a small bastion containing a Maxim-gun at the outside corner. of each of the arms, each bastion flanking two sides-a long and a short-of the zeriba. In the stem of the L, and occupying about twothirds of the total area, are the lines of the troops and the police; immediately beyond them, the shops of the Indian traders, where the men can obtain the petty luxuries of life, and in the other arm of the $L$ the civil officer's residential and office bandas, my ditto, the Government store-also a banda-and our servants' grass huts.

The fort has been recently established in a particularly hostile district, and the possibility of a sudden attack renders a display of force, rigid discipline, and strict precautions necessary. The entrance to the zeriba is closed at sunset, and no living being passes it until dawn, while every one sleeps at his post, ready to turn out at a moment's notice on the sound of the alarm. The bush has been cleared for half a mile in every direction outside 
the "boma," thus allowing for a good "field of fire" should hostilities eventuate. The "boma" is admirably situated from a defensive point of view, as it is on a wide, open hill-top, which falls gently to the stream which winds round three sides of the slight eminence.

The civil officer is away consulting with the head of the Province, and doubtless enjoying all the luxuries of civilization in Simuku, the provincial headquarters, and I am discharging his duties for him to the best of my ability, and with the help of a much-thumbed copy of that remarkable work "The Indian Penal Code."

This somewhat extensive survey of my surroundings has occupied my time, I fear, rather than the supervision of my black warriors, but I know that they are entirely safe in the dependable hands of Colour-Sergeant Simba Mnyema, who now approaches and calls my attention to the fact that we have been on parade for an hour and a half. Giving the order to dismiss, I leave the parade ground and return to my banda for breakfast.

My solitary meal does not take long to dispose of, and then, pipe in mouth, I stroll out to watch the company, police, and porters at work building what will eventually be the civil station on another piece of rising ground about a mile off. The fatherly Government has allowed us the services of one carpenter 
and two masons, and my civilian confrère and myself, turned architect and master-builder, daily superintend the slow erection of the fine stone and sun-dried brick houses which are eventually going to turn the howling wilderness into a bustling city!

An hour's inspection, with much ordergiving and direction, ensures building operations directed into their proper channels, and I am at liberty to turn my face to "orderly room," where a miscellaneous agglomeration of work awaits me. "Shauris" and "Mukitabs" -both of which may be freely rendered as "cases"-of several sorts, but mainly, with African soldiers-as with other types of mankind-dealing with women, food, and money; three primary essentials of mankind in this world. The wife of Private Juma Masudi has eloped from Fort Martin, where all the wives and families of my commando are awaiting the completion of the new station to join their spouses, with policeman Bwana bin Bukoba, now stationed at Entebbe, and the disconsolate husband wants the dowry (or purchase-money rather), which he has handed over to his father-in-law at the time of his nuptials with Mrs. Juma, refunded by the fascinating constable. Said dowry Rs.100. Write to D.S.P. Entebbe on the matter, to get at the other side of the story, and institute 
inquiries as to amount of dowry, if any, actually paid by (probably untruthful) Juma.

Next Private Songoro bin Kombo hales his fellow-soldier Athman wad Musa into the presence, and pours into the presence's harassed ear an interminable narrative of a trade partnership with said Athman, in which two goats, fourteen fowls, "joras" of "Merikani" (measures of calico), wire, beads, and food, all bear their bewildering parts in proving a sum of Rs.8.14.6 due to Songoro from his expartner. Ex-partner then deals exhaustively with same items and introduces further a calf, dead by mischance, a railway fare, and a bag of cowrie shells. Dreading the introduction of fresh matter into the tangled skein of fact and fietion, I award Songoro Rs.3 from Athman, a decision which appears to please both, as they depart together, apparently on the best of terms, possibly to continue their harrowing trade operations together. A little deputation of three succeeds the merchant princes, to complain of the quality of the " matama" (flour) eomposing their ration, on which, they say, they are unable to maintain sufficient strength to work efficiently. Deeision: As there is nothing else to be had, it's "matama" or nothing, and they all know the penalties for not working. Exeunt disgusted. 
Follows the Indian hospital assistant with daily sick report. "Sir," he states, " Private Hamis bin Bokhari has this morning reported sick with stiffness of neck. I diagnose as pretence in order to avoid work. Have therefore painted neck with blistering fluid to act as future deterrent." Evidently a humorist, this portly Bengali. Following him comes the clerical work-reports, returns, requisitions, indents, memoranda, and the like, for signature, for even in Equatoria such things exist and flourish. Among it there is a minute to the Collector. As I myself am doing his work at present, the minute, having been duly delivered at the civil "office," some twenty yards away, will be replied to by myself, returned to myself in my military eapacity, and finally, if the correspondence ceases, duly docketed and filed in two places, also by myself. The which reminds me of an Indian episode. There are in the Himalayas two small stations $A$ and $B$ about a couple of miles apart. $\mathbf{A}$ is the station of a British regiment, one of whose officers performs the duties of station staff officer. $B$ is a hotweather depot for "details" of various regiments from the neighbouring plain stations. The duties of adjutant and quartermaster at B are performed by the S.S.O. of A. At the time of which I write Captain X.Y. filled the 


\section{DEVIOUS CHANNELS}

treble office, and one morning in his capacity of quartermaster attended the early issue of rations at $\mathrm{B}$, and finding something not as it should be, reported the matter to himself as adjutant. In this capacity, deeming the error somewhat beyond his scope, he-at the moment he was also commanding both $\mathbf{A}$ and $\mathbf{B}$ referred it to himself as O.C. Depot, and, again considering that the matter needed to be ventilated in higher quarters, forwarded it to the S.S.O. for submission to O.C. Station. Having received it as S.S.O. and considered it as O.C., he started the document back on its devious way to the quartermaster, who was then permitted by himself, as O.C. Station, to deal with the matter direct.

This is beside the point, so let me return once more to my office. By the time the O.C. Troops has completed his office work the morning has passed, and it is after midday before he can take the magical twenty yards' walk that transforms him into Collector, magistrate, and the rest-in fact, into a full-blown civil officer. Within the Collector's office a miscellany of duties awaits him. More reports, returns, statistics, and the like. Voluminous letters from "the Treasury," delving impertinently into the multifarious accounts with which he is burdened, making unnecessary and offensive queries as to the elusive three 
annas which have escaped from a balancesheet three months old, and are beyond recapture by his financial powers, objecting to the word "ditto" on a pay-bill and to the quality of the ink in which the carpenter's thumb-mark receipt on last month's pay-sheet is stamped. All of which causes one to wonder, though one can in no wise explain, why it is that the handling of money in bulk, the appointment to Treasury or Accounts Department, seems to exercise a baleful influence on every man. Some of the best fellows in the world, after a few months' employment in financial branches of administration, have their natures warped and their consciences deformed. They write impertinent and insulting letters. They insinuate pilfering, and suspect malpractices on the part of all who come under their malignant sway. They deduce picking and stealing in the most innocuous of balancesheets. They become, in short, degraded and demoralized. This is a curious yet incontrovertible fact. If not left too long in their unhappy surroundings, they eventually right themselves, and their natures return to the normal, but an over-long intimacy with ledgers, manifests, and the rest of the horrible implements of finance, produces permanent perversion of character.

One can only wonder why this should be 
so, and suggest that a life of searching for dishonesty, incompetence, and fraud; an existence of chasing defaulting pice and farthings, ha'pence, and annas; of spooring the elusive tizzy through the trackless mazes of double entry, must sap and undermine the morals and geniality of the most open-hearted of mortals.

With so many digressions my day's work does not progress with as much rapidity as is desirable. Suffice to say, then, that my civilian duties, mainly clerical, but in part magisterial, in which capacity $I$ discover a surprising ingenuity both in the commission of small crimes, and in their subsequent defence and denial, carry me on, with a half-hour break for lunch, until $4.30 \mathrm{p} . \mathrm{m}$. Then, shaking off ink and red tape $I$ quit the seat of justice, and cross to my residence for a cup of tea and a cigarette.

Half an hour suffices for these, as well as for the exchange of my uniform for a suit of flannels, and then I stroll once more to the scene of the building operations. Having explained to the Swahili carpenter the exact meaning of a straight line as applied to a door lintel, and having pulled down a bulging wall which the masons, in the absence of white superintendence, have joyously erccted, I spend the time till six o'clock in general supervision and master-builder's work. 
As the six o'clock bugle rings out, labour is finished for the day, and indeed the failing light itself would permit no more. It is too dark for a stroll to the station garden in search of the manifold iniquities of the porter recently promoted gardener, so back to my banda to sit in front of a charcoal fire in a kerosine tin and struggle with the intricacies of the company pay-list, which my own fair hands prepare in duplicate monthly.

At 6.30 "Retreat" sounds, and my coloursergeant and the police sergeant arrive to report "Tamaam" or "All correct," and to receive orders for to-morrow. After their departure more pay-list till dinner at $\mathbf{7 . 3 0}$. Let's do a bust to-night-so out comes a bottle of Burgundy, and my Somali bearer turns on the gramophone, and I dine to the strains of "The Gondoliers," and in fancy the banda's grass walls expand and become beautiful, and I am dining at Prince's, with the Empire to follow. Strauss, Waldteufel, and Tschaikowski waft me through dinner into a long chair with a cigarette and "Mr. Sponge," when there comes an interruption in the shape of a loud challenge from the guard, with an incoherent answer, and a moment later the sergeant of the guard ushers a bedraggled Swahili from the pelting rain outside into the presence of the "Bwana." 
Inquiries elicit that the bedraggled one is a Swahili trader, who, with a stock of trade goods, a companion, three carriers, and two cows, has set out that morning unaccompanied by an escort, in spite of stringent prohibitions and orders to the contrary, from Fort Martin for Cheriko-how could Smithett at Fort Martin let him ? By the way he has fallen in with the followers of one Arabcherson, a truculent chieftain, and has been stripped of his possessions. He himself having taken refuge in flight, he has lost his co-travellers also, and assures us that they have set out for the Swahili equivalent for heaven.

I curse him, together with his ancestors and descendants, actual and prospective, for I have no sympathy with him. Any one who, deliberately disobeying orders and regulations, traverses, well stocked with property, a country inhabited by predatory and blood-loving tribesmen, just now in a specially unsettled state, to my mind deserves everything that he gets, and it's only the Swahili who would do it. In addition to his own miserable self, about whom no one is concerned, he brings trouble on Government officers and troops, to say nothing of the tribesmen, and is possibly the direct cause of the deaths of numbers of better men than himself. I'm only sorry that Arabcherson's elmoran haven't cut his 
scraggy throat, and tell him so in no measured terms.

However, Arabcherson must also learn that he can no longer swell around slitting the weasands of all and sundry, and relieving travellers of their property in the manner of the dear old pre-British days, so to-morrow I must pay a call on him, and in case of eventualities, half a company and a Maxim-gun will come a-calling too. Incidentally all my sympathies are with Arabcherson, who is rather a fine old cut-throat, and who has a tough job to keep his "young men" within bounds in these piping times of peace; so I hope he won't feel that it's "up to him" to give Mr. Hiram Maxim's offspring the chance of taking a hand.

While I am cogitating before giving orders to Colour-Sergeant Simba Mnyema, who has been sent for, my Swahili friend, wrapped in gloom, has also been thinking profoundly, andnow, evidently to cheer me up, announces that a Padré is at Fort Martin, and is coming out to Cheriko under escort to-morrow; from a mission, he add's.

This is the last and final straw. My blast of profanity drives the cheerer-up out of the banda, and Simba Mnyema, laving got his orders, follows him into the rain-streaked darkness, leaving me alone with my thoughts. 
How can Smithett at Fort Martin be ass enough to let a missionary loose on me here ? Isn't the Swahili bad enough? Unless he is coming for the good of $m y$ soul, Smithett must know that his coming is a waste of time. The troops and police are Mussalmans, more or less orthodox, and proselytizing among them is forbidden, while if he tours the country with an escort, the tribesmen will of course imagine the Government is forcing a fancy religion down their throats, and resent it; if, on the other hand, he were to move out of Cheriko unaccompanied, one cowrie shell offered in purchase of his life would be the most wildly reprehensible extravagance. I wish to heaven he and Smithett could have seen this between them. It will be at least four days before I can spare an escort to send him back to Fort Martin, and I've got other things to do beside entertaining missionaries. However, he may run into a fight to-morrow-for Arabcherson's kraal is pretty close to the Fort Martin trackand turn back homewards again.

Which reminds me-I hope at the same time Arabcherson isn't going to fight. It will make things serious for him if he does. I don't fancy he will. Evidently his elmoran weren't killing to-day, or my bedraggled friend would never have reached Cheriko. He would not have run far. His friends probably have run 
also, and run in another direction. Probably by this time safe in Fort Martin, where-let's hope-their story may deter the Padré from trying his luck in these parts. Anyhow, if no one has been killed, the robbery doesn't amount to much. We shall easily get back the goods or their value. If blood hasn't flowed yet Arabcherson won't fight.

Anyhow, it means a day off the work here, a day wasted when every hour is full of work crying out to be done. Beastly nuisance! Damn all Swahili traders; damn Arabcherson, his elmoran, Smithett, and the Padré. So, since between them I have to get out of my warm bed and march to pay my call at 2.30 a.m.--and it's raining hard-the sooner I'm between the blankets the better. And so to bed, and once more, before we go, damn them all-especially Smithett. 


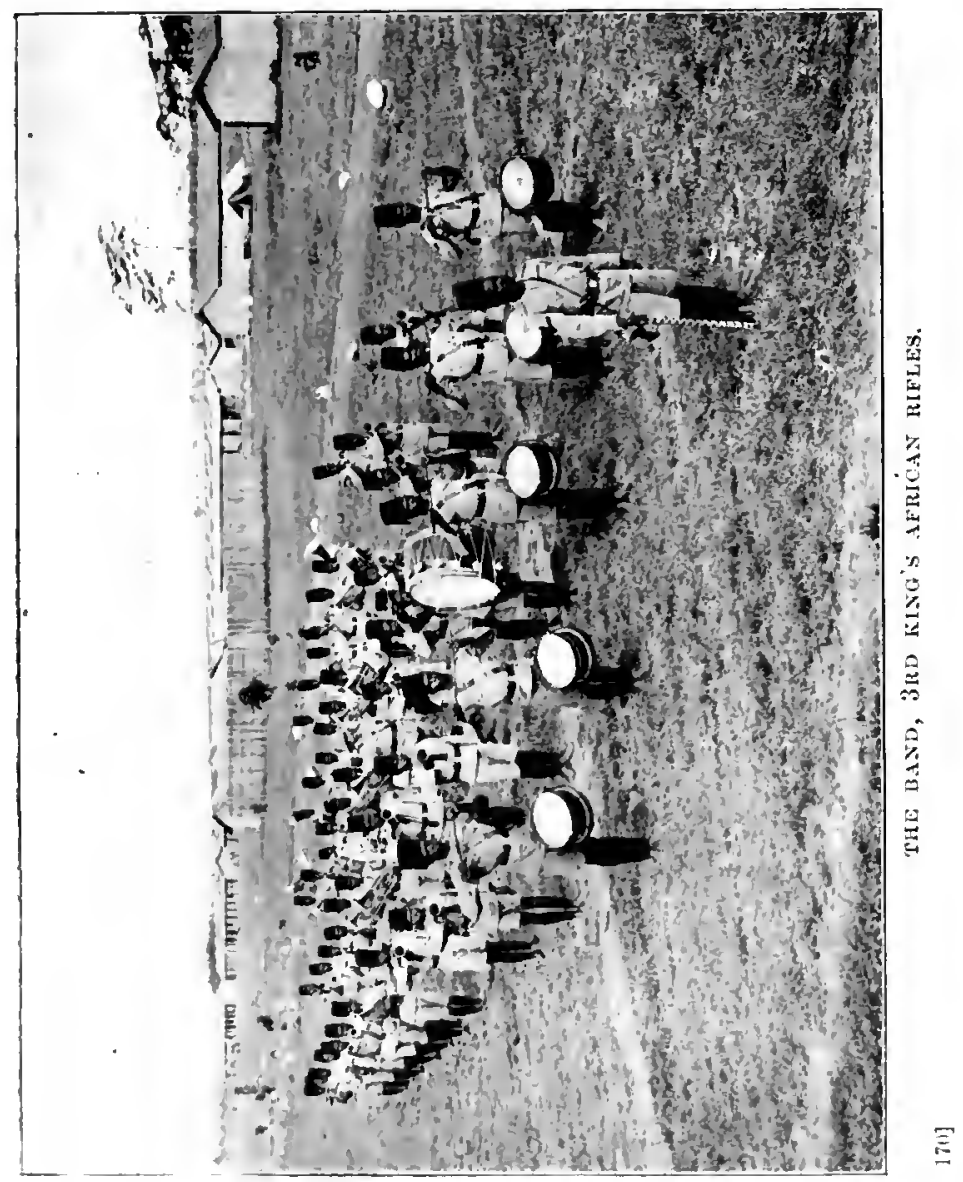




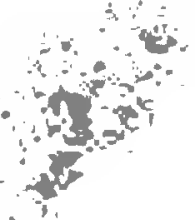




\section{CHAPTER XIV}

\section{A DAY'S PLAY}

THIs morning broke dull and misty. Not a single gleam of sun pierced the rolling masses of mist that shrouded my camp on the lower slopes of Mount Kilimanjaro: a mist so dense that one cannot see more than fifty yards in any direction.

It is six a.m., and my boy has dragged me, sleepily but emphatically protesting, from the one satisfactory place to be in-namely bed.

And the reason he gives for this outrage is that " master has no meat," therefore he must go out and shoot some. Incidentally, my caravan has had no meat for some days, and I suspect Athmani is hankering for a chunk of juicy hartebeeste or zebra on which to glut himself.

However, whatever be at the back of Athmani's mind, I am now thoroughly awake and out of bed, and all chance of a "Europe morning" has vanished. I hurriedly dress, and slipping on a greatcoat, for it is horribly 
cold, proceed to reconnoitre the camp from my tent door. As I have already intimated, the view consists chiefly of mist, varied by a few draggled and unhappy-looking carriers engaged in what currently passes for their morning toilet.

I wonder dully how and what Athmani expects Master to shoot in the fog, and reflect regretfully upon my interrupted slumbers. The question is, is the fog going to lift, or are we going to have a day of it?

Thus cogitating, I tell Athmani to make a fire in the local substitute for a stove-a pierced kerosine tin-and put it in the grass hut opposite, which constitutes my livingroom by day. This done, I tentatively suggest breakfast by way of putting in time until the fog lifts-if it ever means to lift.

Under the cheering influences of kedgeree, ham and eggs, and coffee, matters assume a less gloomy aspect, and by the time I have smoked the first post-breakfast cigarette (best of all smokes), the fog is decidedly lifting, and it really seems as if Athmani stands a chance of gorging himself on "savoury meats such as his soul loveth."

As I have been in this camp for a month, shooting pretty steadily, the game has become rather wild, and has moved from the immediate vicinity of the camp, so my day's ex- 
cursion will probably be a long one. I order my gun-bearers to get out the battery, which consists of a $\cdot 303$, a double $\cdot 450$ cordite, and a twelve-bore shot-gun, for there are lots of quail, partridge, and guinea-fowl about. Having collected porters to carry in the meat which I propose getting, I start.

I make for a large, stony, bush-covered hill, where I have previously seen and missed the only lesser kudu I've ever had the luck to encounter. I still have hopes of a second and more satisfactory meeting, so I seldom go out with a rifle without taking this particular spot on my way, so far with signal unsuccess.

Alas! this morning I once again find my friend from home, and I pass on my way despondent-heading up-wind and keeping a keen look-out for game.

By this time I have left the track and am marching through high grass, drenched with the heavy night dew, and I am wringing wet up to the waist. However, an hour of sun, and that will be remedied. What is much more annoying than the wet are the clouds of mosquitocs, which our passage through the rank verdure disturbs, and which settle down to their morning meal with extraordinary voracity and determination.

My zebra-tail fly-whisk is hard at work, but even so I am bleeding in a dozen places, and 
even my leathery-skinned black retainers seem to be worried.

Passing into a belt of fairly open mimosastudded country, I spot a herd of Coke's hartebeeste grazing near a group of Grant's gazelle.

Although I am out mainly for meat to-day, heads are also an important consideration, and unless there is something specially choice here I am not going to alarm the surrounding country by shooting.

The day is still young, and should I fail to bag anything better, $I$ can call on this herd later on in the day, on my way back to camp. My gun-bearers are already down, crouching out of sight in the long grass, and I step behind a convenient tree and take stock of the unconscious animals through my glasses.

Five minutes' survey convinces me that there is no head out of the common here, so we resume our tramp, bearing a little to the right, so as not to alarm them unduly. The instant we move the sentinel kongoni has spotted us, all heads go up, and the whole herd stands motionless, watching us - then off they go at their clumsy canter, followed more leisurely by the Grant. For the next halfhour nothing is seen, and then from a little hill-top a herd of about fifteen oryx is observed, about a mile and a half up-wind of us, un- 
fortunately in rather open country. Here at last is something worthy of our attentions.

Off we go in a bee-line towards them for a mile or so, using a handy watercourse to conceal our movements.

Then at about half a mile away I drop my porters and two gun-bearers in the cover of the watercourse. I, with one gun-bearer carrying the $\cdot 303$, start on the interesting part of the day's work. For, at any rate with nondangerous game, it's the stalking, not the shot, that is the sport. To-day the stalk is fairly simple-the wind is right and fairly steady, not gusty and changeable as the African breeze so often is ; there are clumps of long grass, and a fairly convenient line of bushes. At first we merely walk, our bodies bent, from bush to bush ; then, as the bush grows thinner, it becomes a case of hands and knees, and we slowly creep forward until we are at the last available bush, hot and perspiring -and still 300 yards away from our destined victims.

The oryx are perfectly unaware of our presence, and some of them are lying down, while the rest are leisurely browsing. They are in a patch of absolutely open country, the grass about a foot high, but there are fortunately patches of longer grass and some small mounds-like large mole-hills-of which I shall have to take advantage to get within shot. 
Whilc getting breath, I scan them through my glasses, and notice one very nice-looking head, which excites my cupidity. I leave my gunbcarer ensconced behind our bush, and, taking my rifle, I lie flat on my stomach, and proceed to enact the part of a snake. Foot by foot I wriggle through the short grass, making for a hummock about 100 yards to my front, and after what seems hours of exhausting exercise, without much definite progress, I find myself at my goal. Cautiously, very cautiously, I raise my head and reconnoitre. So far everything has gone well : my quarry haven't the faintest idea that they are the object of my attentions. Unfortunately, however, my selected victim has moved away from his former position, and is rather too far off to give me a certain shot. I notice a clump of longish grass about 75 yards nearer, and now I am faced by a quandary-shall I try an uncertain shot from where I am, or shall I risk a nearer approach ?

While I am debating the question my oryx settles it by lying down, making a shot from my present position an impossibility. I withdraw my head, and turning on to my side, inhale deep gulps of air before renewing my crawl. Another seeming eternity-in reality I suppose ten minutes-and I'm behind the sheltering grass, sweating from every pore and 
without a breath in my body, but triumphant, for a hasty glance has assured me that the herd is undisturbed, about 100 yards away. As I have got here safely I don't think there is much risk in waiting till I've got my breath, for I'm far too unsteady to shoot, so I turn over on to my back and gasp for fully five minutes. All the time $I$ have an intense longing to shoot, for I feel convinced that the herd will have got the alarm, or will move off, or that something untoward will happen, and I am horribly afraid that all my labour will have been in vain.

"At least," I think, "I must look and assure myself that nothing has gone wrong"; but I take myself firmly in hand and refuse to accept the tempter's suggestions, and so remain motionless.

At the end of five minutes I can't stand the suspense any longer, and turning over, I take off my sun-topi, slip over the safety catch of my rifle, and peer through the grass in front. As I knew perfectly well at the back of my mind all the time I was fighting my excitement -they have not moved; but, having once succumbed, I simply can't lie down again to another five minutes' wait, and so, though I am not properly steady, I get ready to shoot. But my selected beast is still lying down, and I can't get a decent shot yet, so I take a 
general line on him along my rifle and give a long, loud whistle.

Instantly every beast in the herd is on his feet, looking round for the cause or meaning of the strange sound.

My big bull is standing broadside on 100 yards away, giving me an ideal shot. I cover the point of his shoulder and press the trigger, and the report is closely followed by the welcome thud of the bullet. He gives a bound, dashes about 20 yards towards me, and stands stock-still, evidently hard hit, and again broadside on. The rest of the herd are motionless, trying to locate the sound of the report. I draw a bead on my bull-this time on his neck-fire, and down he comes with a crash; the rest of the herd are off on the wings of the wind. I rush forward, reloading as I go, but there is no need of another shot-he is finished.

Up dashes my gun-bearer, knife in hand, to "hallal" him, without which ceremony no good Mussalman will eat of his flesh. His throat safely cut-at the base of the neck, to save the head-skin - a shout brings my party out of cover, and in a couple of minutes they are hard at work beheading him and whipping off his skin, whilst I enjoy a cigarette under a neighbouring tree. I am feeling quite pleased with myself, for my measuring-tape tells me 
that his horns are $30 \frac{1}{2}$ inches, quite good for Oryx callotis, and my best up to date.

So far so good, but I want more meat, for I expect a big safari (caravan) into camp tonight, and though oryx-tail soup and steaks want a lot of beating in the way of food, I feel that a leg of impala, which is common hereabouts, would add variety to this evening's dinner. Accordingly, leaving five porters to bring the meat into camp, I stroll on with the remainder of my entourage, reflecting that I ought to have waited longer before taking my shot at the oryx, for, being rather unsteady, my first shot hit him too far back, missing the heart, and it had taken a second to kill him. Whereas, had my second been available for another oryx-my first having been fatalI should have been relieved of the necessity of looking for more porter's meat.

However, I haven't much farther to look to complete my supply, for in the next halfmile we run across a solitary bull wildebeeste, peacefully unconscious of the proximity of his enemy man. As he is only 150 yards off I don't propose to try to get any nearer, for the wildebeeste is a tricky fellow to stalk. Therefore I step to the nearest tree to get a rest for my rifle, and to avoid risks-for a wounded wildebeeste will carry a wonderful lot of lead-I take the $\cdot \mathbf{4 5 0}$ for this shot. 
At this moment one of my men treads on a twig, which snaps with a terrible noise; the wildebeeste swings round and is facing us, his head up in the air, a picture of alarm. For a second he stands without a quiver, and in that second I let fly my right barrel at his hairy chest, and he comes crashing down, and in another moment the knife is at his throat. My ever-present tape shows him to be $27 \frac{1}{2}$ inches, which is quite a respectable head.

As it is now twelve o'clock the sun is pretty strong, so, having supplied my larder fully, I lie down in the shade of a spreading acacia, hard by a rippling stream of delicious, icecold water, which washes down the biscuit that forms my lunch, and after a cigarette I'm sound asleep, dreaming of oryx with three-foot horns and other fascinating creatures of the same type. At two o'clock my gunbearer wakes me with the news that it is time we were starting homewards. We strike for camp, making a detour to a patch of woodland which I know of old to be a favourite haunt of impala, and sure enough we find a herd there and I bag a fair buck.

I have now finished with the rifle for the day, unless something exceptional turns up, and as I stroll campwards, scatter-gun in hand, through country teeming with birds, I manage 
to collect a mixed bag of $12 \frac{1}{2}$ brace-partridge, guinea-fowl, and quail.

Back to camp to a bath and tea, having missed an ostrich and viewed a lot of zebra, Grantii, and hartebeeste on the way. I find the expected safari has arrived with no less than three Europeans and-a stroke of luck-all of them bridge-players, which means a rubber to-night.

As we sit in the still evening and watch the glory of the sunset, turning from the deepest crimson to ever-varying shades of salmon-pink and yellow on the snow-erowned peak of that most glorious of mountains, Kilimanjaro, the talk turns naturally to sport, and rambles from elephant on the Nile and lion in Somaliland to the mighty boar of India and the Kadir Cup, the Ovis Poli and the Markhor of Thibet, the snipe-jheels of the Punjab, to polo and Army Cup weeks at Lucknow, and to never-to-be-forgotten memories of glorious Goodwood and Cup days at Ascot.

Then, as the stars slip out and the glorious African moon floods the silent world with her pale light, it grows cold, and we move inside to sit down to a dinner, mainly the product of rifle and gun, and as good as or better than many a London dinner-for my Goanese cook is an artist, and in honour of my guests he excels himself to-night. Bridge succeeds 
dinner, but after a while cards are thrown aside, and we gather round the fire, and over the national drink of Scotland the tales of sport are renewed, and with four Europeans gathered together in the wilderness it bids fair to become a "strong night," as a German friend of mine was wont to term it.

I have tried to put on paper-poorly enough, I fear-a day of my life in Africa, that Africa whose indescribable fascination all who know the country and who care in the least for nature must have felt.

The hackneyed Arab saying, that he who has drunk of the waters of the Nile must always return, is indeed true.

What this strange fascination is $I$ cannot tell. I only know that once a man has felt it he will never escape its grip; and, steady as fate, it will draw him back to the old seenes which he loves, it may be to lay his bones there in the van of the Empire, one more member of the "Lost Legion."

Whatever his fate, whatever his ultimate future, if Africa has him in her grip one thing is certain, leave her as often as he may-he returns. 


\section{CHAPTER XV}

\section{AN ELEPHANT-SHOOT}

I MET with the following experience while after elephant in the distriet around Nimule, a Uganda Protectorate station on the White Nile, almost opposite the Congo Free State station of Dufile. This part of the country swarms with elephant, the left or Congo Free State bank being, perhaps, the more plentifully supplied, since they are less shot and hunted there than in British territory.

During the rainy season, which extends from the end of Mareh to the middle of December approximately, the Nile Valley is to a great extent a swamp, and is entirely covered with long, coarse elephant grass from ten to fifteen feet high, which renders the shooting of anything smaller than elephant an impossibility, and causes the pursuit of the latter to be a matter of considerable difficulty and danger. On this account the Protectorate officials stationed in this part of the world seldom or never sally forth in chase of the elephant until the advent of the dry season, when the 
whole of the grass is burnt, and one can pursue one's game under very much more pleasant conditions. The one and only advantage which the wet season possesses is, that while the country is thus thickly overgrown, the elephant remain almost stationary in certain localities, coming nightly to feed upon the crops of the unfortunate natives, for this part of Africa is fairly thickly populated. Elephants are also to be found much nearer to Nimule itself at this time than during the dry season, probably on account of the practical cessation of shooting. I have myself left Nimule in the carly morning, shot my elephant, and been back in the station in time for a late luncheon, and there is a story extant of a solitary bull elephant having strolled across the Nimule parade ground at about 5.30 p.m.

In the dry season, on the other hand, elepliants range farther afield, and rarely remain in the same locality for many days together, being, I suppose, kept on the move by the polite attentions of local officials. It follows, then, that if the sportsman is pressed for time, and is content to take his chances witl rain, swollen streams, swamps, mosquitoes-especially mosquitoes-and fever, he has a better chance of coming up with his quarry in the limited time at his disposal in the wet season than in the dry. This is 
especially so, as the natives are very good at bringing in news as to the whereabouts of elephants, both on account of the damage they do to crops and with an eye to backsheesh should the sportsman prove successful.

However, to leave generalities, let me turn to my actual experiences during a day after elephant.

I left Nimule early one morning, and, crossing the Unyama River, halted for a short time at the village of Affudu, where I obtained four native trackers, who professed themselves acquainted with a place, some six hours distant, where, they assured me, elephant were to be found. Accordingly I pressed forward, and at about four o'elock camped on the banks of a small stream flowing into the Nile. While camp was being pitehed I sent out the trackers to look for signs of elephant, and in about an hour two of them returned, breathless with excitement, to tell me that they had just seen a big solitary bull, with heavy tusks, travelling slowly up the bank of the stream. I snatched up my double $\mathbf{4 5 0}$ cordite and hurried off. We soon came to the place where the tusker had been sighted, and started to follow up his tracks. However, after going some little distance without viewing our quarry, the approach of darkness compelled us to return to camp. 
The next morning, by the light of a tropieal moon, a small party left camp in quest of our game. In advance were the four trackers, then myself on a mule, husbanding my strength in case of an all-day tramp after a scared or wounded beast. Behind me came my syce and two Sudanese gun-bearers. Just as the earliest streaks of dawn were lightening the east we struck the fresh spoor of a single bull, and, relegating the mule and his syce to the rear, I pressed forward on the heels of the trackers. After about an hour's steady progress we reached a huge tree, under which the spoor led, and here a halt was called while one of the trackers ascended to spy out the land. A moment later and a whisper from above of "fil " (elephant) sent me also elimbing skyward. From my lofty perch I could see three elephant, or rather, the tops of their heads, which was all the view that the long grass permitted. After about ten minutes' watching, one of them, moving slowly forward to a spot where the grass was somewhat shorter, revealed a glimpse of a pair of tusks $120 \mathrm{lb}$. each, if an ounce. Determining that this was good enough for me, I proceeded to form a plan of campaign.

The big bull that I had fixed on for my prey was about 180 yards from the tree, and on each side, and about 150 yards distant from 
him, was another elephant, whether bulls or cows I could not tell. The wind was favourable, though a shade gusty, blowing directly from the elephants towards us. Here, just two words to the uninitiated hunter in search of elephant. First, watch the wind. Secondly, never, if possible, shoot at a distance of over twenty yards. Paradoxical as it may sound, with dangerous. game, such as elephant or rhinoceros, the nearer you are the safer you are. The reason is fairly obvious-at twenty yards even the most indifferent shot should be certain of hitting a vital part, and one cartridge lays your game dead at your feet; whereas a long shot only wounds him (for the vital points are easy to miss), and you spend the remainder of your day in pursuing a wounded animal, or he reverses the position, and puts in a few lively minutes hunting you -with, possibly, unpleasant results. With elephant a shot at close quarters is especially desirable, since to pierce the brain-in my opinion, far more satisfactory than the heartshot-one must hit an area between the eye and the earhole, about the size of a small plate, and this shot, though easy enough at twenty yards, is the reverse at one hundred.

To return to my story. I decided to follow up the track we were already on; indeed, there was no alternative, as the whole place 
was one thick, impenetrable tangle of elephant grass. Therefore, leaving all my retainers at the tree, I advanced, rifle in hand, accompanied by one gun-bearer carrying a $\cdot 256$ Mannlicher loaded with solid bullets. We advanced cautiously for about 120 yards, and then, from our right, we heard the curious internal rumblings of the elephant. I sent my gun-bearer up a small thorn tree to reconnoitre, and in a moment he was down again with the news that the big tusker was about thirty yards away, coming slowly in our direction. As the ground ahead seemed even thicker than where we were, I decided to await his arrival in our present position. In the thick stuff the breeze, or what little could be felt, was blowing from left to right. The sound of rumbling gradually drew nearer, and suddenly, about fifteen paces away, I espied the top of an elephant's head and his huge flapping ears advancing in my direction. With such a limited view a shot was impossible, so I had perforce to give him a chance of coming nearer. For a good ten minutes, however, he remained where he was, tearing off the branches of a tree with his mighty trunk.

I recall those ten minutes as some of the most thrilling I have ever spent, because, in addition to those in front, there were rumblings both to right and left, and I realized that I 
had got amongst several elephants. Situated as I was, in grass far above my head, with a maximum range of vision of fifteen yards in any direction, in some far less, I felt that things were getting rather warm, and $I$ was overjoyed when the big bull in front put an end to the horrible suspense of inaction by resuming his leisurely way towards me. Slowly he advanced, nothing visible but the enormous ears and trunk, until he arrived within six paces of me, a thick mimosa bush being between us.

Although up to the present a shot had been impossible, and even now I could only catch odd glimpses of him through the leafy screen, I made up my mind to have at him without further delay, for a couple or more strides must have brought him on top of me or given him my wind. I tried to estimate the whereabouts of his brain, and let drive my right barrel at the spot where I judged it to be. Down he came with a crash, and I could just make out that he was lying on his back, his four legs twitching upright in the air. I hastily crammed in a fresh cartridge and started to push my way round the bush towards him, when up he got very groggily. When he was half-way up I tried for his heart with my right barrel without any appreciable effect, and just as he had struggled up again 
to his feet I once more grassed him with the left in the head. While I was reloading up he staggered again and made off, and at about fifteen paces away turned obliquely from me and received two more bullets, which raked his enormous body, without, however, stopping him, and he disappeared into the long grass.

Reloading, I followed his spoor, which, passing through very thick cover, crossed an open space with grass only waist-high and about thirty yards square. Here it was that I saw him again-but I heard him first-for when we werc almost in the centre of the open space I heard the shrill squeal of rage which heralds a charge, and saw his mighty head, trunk in air, ears outspread, appear through the grass to my front.

At the distance (fifteen yards) hesitation or flight would have been equally fatal, and, with that extraordinary coolness which comes in the presence of imminent danger, my rifle was at my shoulder and I had planted a bullet into the massive head. The head instantly vanished, but to this day I do not know whether he came down, or merely went back on his tracks, though I think the former, for the instant that I fired I heard a second report directly behind me, and knowing that my gun-bearer was far too good a man to fire in 
my direction from behind, I instinctively swung round with my rifle still at my shoulder. As I turned I saw, to my horror and dismay, a big cow almost directly behind us, breaking out of the long grass and evidently bent on mischief, though my gun-bearer's bullet seemed to have somewhat damped her ardour. My bullet, which hit her somewhere, evidently decided her, for she swung off into the long grass once more, leaving my gun-bearer and myself the only tenants of the open space.

I have spoken of the coolness which danger produces : by this I do not for a moment mean to insinuate bravery. It is in my opinion mere automatic instinct that causes man in the presence of sudden, imminent, approaching danger, to beeome a machine-like, ice-cold entity. Sheer lack of time forbids the hesitating consideration of which is born fear. When the danger is over the reaction causes nerves to quiver like harp-strings, and induces something like collapse. On this very occasion, when the two elephant had vanished, the reaction produced violent nausea. This by the way, however.

We both reloaded, and took counsel together, agreeing, as we were in a comparatively open space, to stay there for a while, and not further tempt fortune by venturing again into the thick stuff. Accordingly I 
ascended a small mimosa tree, whence I could get a view over the top of the high elephant grass. From my perch I could catch occasional glimpses of six elephant, five of which I decided were cows, and the other I took to be the wounded bull. All had their trunks raised, and were obviously trying to get our wind. Fortunately, however, the breeze for a time held steady, blowing from the elephants towards us. After a time I was able to get another shot at the bull, and once more I hit him and down he came, only to rise again a minute later, swaying as he stood and evidently very sick indeed.

As if caused by my shot, the breeze immediately began to shift, and to blow in gusts from all quarters of the compass. This had the result of further exciting the elephants, the wounded cow in particular. During the next hour she got our wind several times, and made savage rushes in our direction. However, on each occasion the wind dropped before she got near enough to necessitate shooting, though once she got almost to the edge of the clearing, and my rifle was at my shoulder, when the wind veered and her charge died away. After about an hour of this kind of thing I decided to trust to luck and make an effort to finish off the bull, who was standing motionless in one spot under a large tree; 
accordingly we entered the long grass, following the blood-track of the wounded animal. Then followed a period of excursions and alarms. At a point where the track took a sharp curve we were unable to pass without giving our wind to the angry cow, whom we could hear moving about ominously near us. Eventually she scented us and charged, but we managed to avoid her by diving into the long grass to the right of the track, and she dashed past us, not more than thirty feet away, without discovering us.

All our efforts to get at the bull were foiled by his angry wife, and after about threequarters of an hour of hide-and-seek in the grass, all the elephants moved off, the bull evidently stronger than he had been an hour before. I still felt certain of getting him, as I felt sure that his death was only a question of hours, and once dead the cows would leave him. I followed up his bloodspoor, which passed under the big tree at which I had left my trackers and syce. I found them all up the trec, and they told me that the elephants had just passed, frightening the syce, who was on the ground, very considerably. As soon as they were seen coming in that direction by the people aloft, he turned loose the mule and joined his friends in the branches. He then descended, and turned 
up with the mule while I was talking to the trackers. They told me that besides the bull there were five cows, three of them with calves, and that the bull was very hard hit, and bound to die very shortly. They also told me a yarn which I had often before heard, but never really believed, that the cows had surrounded the dying bull, and were holding him up and helping him along with their trunks.

Hastily despatching a messenger to get camp struck, and to bring the safari along the elephant-track, I started off to follow it up. I followed that blood-bespattered trail for the rest of the day until four p.m., when, after twelve hours of tramping, with nothing to eat since breakfast (which I had since got rid of) I felt too done to go any farther, and sat down to await the arrival of my safari, which turned up about an hour later. Then, while camp was being pitched, a big elephant was sighted on an open hill-top to the right about a mile from the camp. With the aid of my glasses I made certain that he was my friend of the morning, looking decidedly the worse for wear, and now quite alone. He had evidently moved in a circle and was coming back on his tracks, since the trail I was following ran almost due west, while the hill on which he now was lay north of the camp. It was now 
too late to pursue him farther, but conviction deepened into certainty of my getting him early next morning.

However, as will appear, the old saying "There's many a slip" was once more to prove its truth. While reflecting upon the morrow, I was interrupted by a Swahili porter rushing up and whispering hoarsely, "Tembo, bwana, tembo-karibu sana" (elephants close at hand). Hastily following him, rifle in hand, I saw on the opposite bank of a little stream three elephants, which the first glance showed to be cows-each with its calf. There they stood in an open glade on the bank of the stream, and there they stayed for fully twenty minutes, within seventy-five yards of the camp, apparently quite undisturbed by the presence of man, and by the various noises from the tents. I sat and watched them, rifle on knee, cursing the accident which destroyed my camera some fortnight before. At length they turned, and, walking quietly away, disappeared into the jungle, leaving me to the pleasures of dinner and bed.

The next day I can only characterize as one long chapter of accidents. To commence with, a heavy rainstorm in the night washed away all traces of blood. This at first seemed a matter of small importance, as there were still the foot-marks to guide us; but, after 
following them for about two miles, we reached a place where a large herd of cows had come. on to the traek during the night and had obliterated all traces of the bull. After spending some hours in vainly trying to piek them up again, in the process of which we got mixed up with the aforesaid herd of cows and had one or two narrow shaves, I deeided to return to camp and cut across eountry to the place where I had seen my bull the evening before. This I did, taking my safari with me, with the result that we got badly bushed, and it was not until four p.m. that, after eutting our way through almost solid bush, we emerged on to a path.

As we were then a long way from Nimule, which it was essential that I should reach next day, I reluctantly and with a heavy heart decided to bid farewell to my elephant and to set our faces in a homeward direction. This I did, and reached Nimule late the next evening. I promised the traekers big rewards if they managed to bring in the tusks, and the promise of backsheesh sent out several more natives from Affudu for the same purpose.

However, fate was against me, for when I quitted Nimule for good and all, which I did some days later, no news had been brought in. Subsequently $I$ heard that my trackers found the dead elephant, but, alas and alas! 


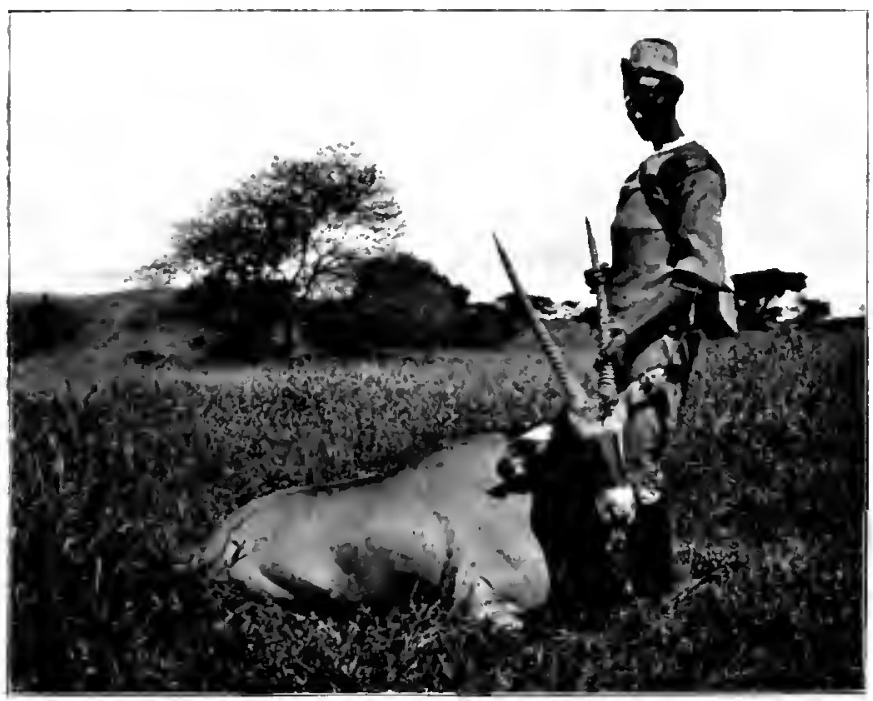

ORYX CALIOTIS.

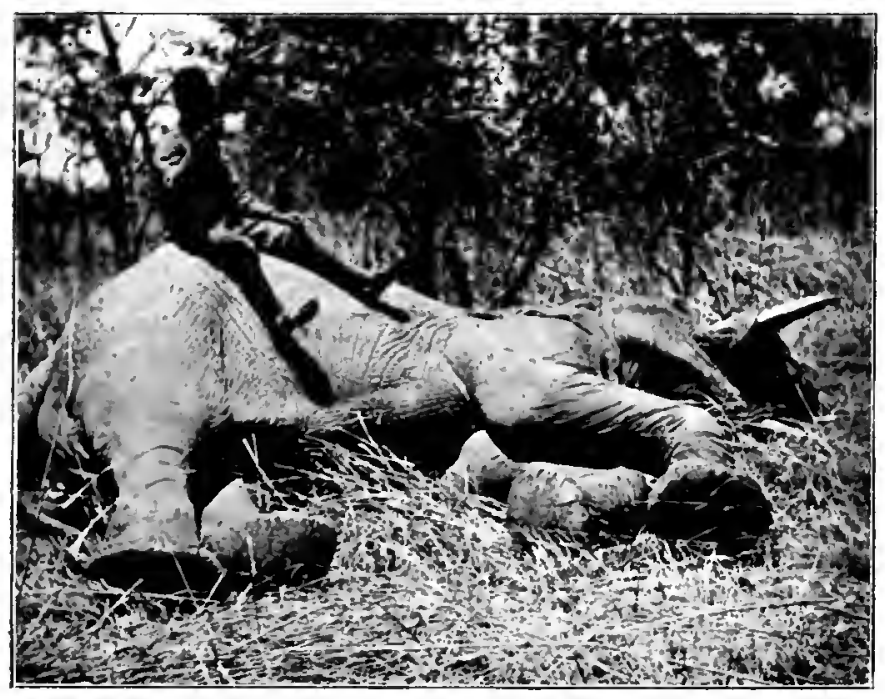



minus the tusks, which some wandering party of natives must have extracted and borne off in triumph, to be sold doubtless to the next trading caravan.

So, most unfortunately, ended my adventure with the biggest tusker that it has yet been my lot to encounter. 


\section{CHAPTER XVI}

LEAVES FROM AN AFRICAN GAME-BOOK

At the beginning of 1905 my friend Diekinson and I found ourselves in camp on the banks of the Guaso Nyiro River some miles above its exit in Lake Natron, a large, shallow, hot, soda-impregnated sheet of water on the boundary between British and German East Africa. We were doing duty with the escort of the Anglo-German Boundary Commission, which was then engaged in delimiting, fixing, and marking with large stone cairns the line of demarcation between the two countries. As the escort, consisting of a company of native African troops, was divided up into small parties amongst the many surveying camps, our duties were comparatively light, more especially as there was no prospect of fighting, and at the time of which I write we were in charge of the main base supply camp of the expedition, in which rations, etc., were stored on their arrival from Nairobi, the capital of British East Africa, and from which the supplies were forwarded to the various 
outlying camps and surveying stations. As the country we were traversing was for the most part uninhabited, no grain could be procured locally, so the entire stock of rice and grain, which formed the staple food of the three or four hundred natives employed by the Commission, servants, soldiers, and carriers -the only method of transport in these partshad to be brought out by porter from the nearest point on the Uganda Railway, which at that period of the expedition was Nairobi.

Although the transport service was a big one, our duties were by no means arduous, and as we were both keen on sport in most forms, we put in our spare time-of which we had a'considerable amount-in the pursuit of game, both big and small, in which the surrounding country abounded. Both of us were very keen on bagging a buffalo, which species abounded hereabouts. Eventually we succeeded by driving a herd as recounted in a former chapter. We also were pretty successful with other species; and both of us acquired remarkably good bags while at this camp.

Being in the Great Rift Valley, the climate was unpleasantly warm, and as a relief from the heat we constructed a bathing-place close to camp by damming the river, and, as there were no erocodiles, most of our time, when not engaged in shikar, was spent in the water. 
Before bagging our buffaloes we had several encounters and experiences with them. One of the most tantalizing, I think, was lying on a hill-top and looking down into a big swamp, and counting therein-out of shot of coursesome three hundred buffalo. Having a very wholesome respect for bufialo-especially in quantities-we realized that a pursuit in the swamp would be inadvisable-in addition to being useless. On another occasion, when looking out for game from the top of a small eminence, I saw a small herd of buffalo come out from some thick bush into an open space. They crossed the clearing slowly until they came to a track across it which had been followed by myself and my entourage some little time previously. At once they swerved from the course they were pursuing and retired again into the thick bush. This formed a somewhat striking example of the keenness of scent in wild animals, and of their instinctive dread-where they have been harassed-of man. Where they have not been shot and hunted, this dread is not nearly so marked. In a game-rescrve, which was also uninhabited country and quite away from the beaten track, I found that the game would let me walk up to within twenty or thirty yards of them, quite openly and without making any use of cover. Even hcre, however, I noticed 
that they were much more alarmed by the scent than by the sight of man.

In another camp near the Guaso Nyiro I had one or two encounters with lion, which simply swarmed thereabouts. Unfortunately they mostly occurred when I had run out of ammunition for both my rifles, owing to a silly mistake of a Neopara (hcadman of porters) in getting some loads mixed up and despatching my cartridges somewhere to the Back of Beyond. In consequence, I was reduced to shooting with a Martini-Henry belonging to my orderly. As this rifle had been "cast" from the Navy somewhere about 1887 as worn out, and had ever since been in pretty constant use, it can be imagined that it was by no means an ideal weapon. If it had only possessed any one particular vice I should not have minded very much, as, when one gets to know one's rifle, one can allow for its peculiarities and make pretty decent shooting, even if it throws feet out in any one direction, so long as it is only consistent in its malpractices. This particular weapon, however, was very catholic in its faults, and the best that one could hope for was that it would hit somewhere within nine inches or so of the spot aimed at, the direction it favoured being entirely a matter of chance.

With this deadly weapon I was making my 
homeward way one afternoon, feeling rather pleased with myself, as I had bagged my first eland a few hours before, despite my rifle, when $I$ saw an animal of sorts lying motionless under a solitary stunted mimosa tree in the open plain. Closer inspection through my glasses revealed it to be-a lion asleep. As I was a long way from camp and it was getting fairly late, I thought that by the time I had settled the lion it would be too late in the day to start back there; I therefore despatched my Masai orderly to headquarters with orders to bring out some porters with a tent and some food, and to pitch camp on the banks of a small stream not far from where we then were. After watching him depart at the long, loping trot at which the Masai cover such astonishing distances, I and my Somali gunbearer turned our attention to the lion, which was still slumbering peacefully.

We walked up to within twenty paces and took stock of him. He was a young male in good condition, but carrying a very poor mane. He lay on his left side with his back towards us, so motionless that for a moment I thought him dead, and it was only the regular rise and fall of his breathing that showed that he was alive. Of course if $I$ had had a grain of sense I would have realised that $I$ had absolutely got him, and would have walked 
up to within a few feet of him and blown his head in point-blank, at a distance at which even my old blunderbuss couldn't have missed; but $I$ suppose that the very fact that $I$ was carrying a rifle that $I$ could not trust made me a bit "jumpy," and I did what under the circumstances was about the most foolish thing I could possibly have hit on. I clean forgot my pet axiom with dangerous gamethe nearer you are the safer you are-and, like a fool, went down on one knee about eighteen yards away from him and lct drive at the back of his neck, hoping to break his spine.

The consequences were exactly what might have been foreseen; the bullet took him too far back, somewhere between the shoulderblades, missing his spine and all his vital parts. He let out a very deuce of a roar, sat up on his hind-quarters, and stared at us, snarling. The beastly rifle chose this most opportune moment for jamming, and I knelt there, struggling with the infernal thing, trying to get the empty case out. During my fight with the rifle the lion got up and came a very little towards us, roaring. I remember that, as I fumbled away at the breech and tugged at the under lever, it flashed through my mind what a consummate ass I must look, playing about with a useless rifle within a few yards 
of a wounded and naturally irritated lion. I don't remember that I felt afraid or that the inclination to bolt (which would have been the most hopeless possible thing to do) came into my head; all my thoughts and energies were devoted to getting my rifle into working order for a second shot; what my gunbearer's feelings were I don't know. Very fortunately for us, something about us-I can't imagine what, but it may have been my language-seemed to alarm the lion, and he incontinently turned tail and bolted for a bush-grown nullah about a couple of hundred yards away. Just as he was disappearing into the scrub the rifle succumbed before my frenzied attacks, and I sent a second bullet after him, scoring a very handsome miss.

We proceeded to the nullah edge, and, peering over, reconnoitred. We caught a glimpse of him moving off through the bushes, but he wasn't sufficiently distinct for a shot. My Somali, to whom fear was an unknown quantity, was mad keen to follow him up, for there was no doubt but that he was pretty sick. Under the circumstances I couldn't very well decline and show the white feather before a native-much as I should have liked to-so, greatly against my better judgment, and with much inward cursing of myself as the greatest fool alive, we climbed down into 
the nullah. We soon heard our quarry growling in a depression in front, overgrown with long grass and clusters of low bushes. Excitement now mastered all my wiser instincts, and I advanced slowly upon him, my Somali, knife in hand, following on my heels. Looking back now in cold blood, I realize that it was a stroke of extreme good luck that the lion did not wait for us, but decamped unseen; but at the time we were both quite annoyed to find that he had got away, and spent a couple more hours hunting for him, without, however, any success. At last we were reluctantly compelled to give it up and make for the stream where we were to meet the safari bringing camp.

We arrived at the rendezvous half an hour before sunset, and I was feeling pretty hungry, as it was well past the time of my daily meal. I may here mention that as a general rule when shooting I eat, like the natives of the country, only once a day, on my return to camp, usually about five o'clock in the evening. This meal, with the exception of a cup of tea when I leave camp in the morning, usually about 4.30 a.m., is the only food I take in the twentyfour hours, and I find that I thrive and do well upon this regime. However, on this occasion I was decidedly hungry, and we were fortunate enough to discover a bee's nest in the ground 
near at hand. This we promptly proceeded to smoke out with dried grass, etc., and when we had got most of the bees stupefied we dug out the nest and got at the honey, getting a fair number of stings from the less soporific inhabitants in so doing. I shall always look back on that meal as one of the best I have ever tasted. The hunger-satisfying powers of honey are wonderful, especially when it is eaten as we ate it then, holding the comb like a slice of bread and butter and biting off mouthfuls from it. We were really remarkably lucky in finding such excellent provender, as the safari didn't turn up till about 9.30 p.m., when, in spite of my impromptu dinner, I was still reasonably hungry. It is wonderful what an appetite a twenty-four hours' fast can produce!

We spent our period of waiting, sitting over a fire which we kindled, listening to the roaring of lions all round, and indulging in much tobacco and talk. I find that it is on such occasions that a native opens his mind-as much as he ever does-and that one can learn the little of Eastern mind-workings and trains of thought that it is ever given to a European to acquire: provided always that your native knows, likes, and trusts you, for he is a shy and secretive animal, and it takes years of intimate contact and knowledge, coupled with 
absolute straightforwardness and just dealing, before he will either draw back in the least degree the veil of silence, or cease from the floods of unmeaning verbiage with which he hides his thoughts and feelings from the view of the white man.

Dinner and bed eventually arriving, I slept the sleep of the just, having made up my mind to spend some days in this locality to try to get my wounded victim, and also some of his kinsmen, of whom, to judge by the roaring, there were a considerable number about. I may as well say that I never did get the wounded beast, though he eventually died. This I know because every night we heard his groaning howls, quite distinguishable from the roars of his companions, but on the third night he was silent, which proved that he had departed this life. In the scarch for him on the following day, however, I caught a glimpse of one of his confrères, but of too momentary a nature to allow of a shot. Later on I came across, lower down the nullah, the body of a rhinoceros, which I had shot some days previously, before my cartridges had given out. The ground all round the carcase was simply covered with the prints of lions' pads, proving that they came nightly to feed, for, in spite of assertions to the contrary, lions not only eat carrion but seem to prefer their meat " high." 


\section{LEAVES FROM AN AFRICAN GAME-BOOK}

However, they had not made much impression on the rhinoceros, as I had not previously taken any of his skin, which was not yet sufficiently decayed to yield to their teeth. I now had several big strips taken off to give my feline friends a chance, and, as it was full moon, I turned on my followers to build a mâchan of branches in a big tree right above the body. The mâchan was completed in a few hours, and we made our way back to camp, being charged and scattered en route by a small rhinoceros, just as we were leaving the nullah, but with no ill results to any one. I decided to allow time for the scent of man to disappear, so did not occupy the mâchan until the following night, and resisted the temptation of approaching the spot in search of fresh spoor during the next day, which I spent in a trip to the main camp to see that things were progressing all right in my absence.

On my return I started off with Mahomed Adan, my Somali gun-bearer, and ascended to the mâchan at about six o'clock for an allnight vigil. Although $I$ had made frantic efforts to get my ammunition, sending off relays of messengers, it hadn't turned up, so I had to rely on my prehistoric weapon. However, as we were so close to the "kill," even it could hardly miss. Despite the cold, and it can be cold in Africa when it likes, and 
the far from dainty smell from the body of the rhinoceros, that night was one of the most fascinating $I$ have ever spent. As the sun went down behind a golden bank of cloud, and the sudden tropical darkness fell, the surrounding bush was as silent as the grave. Then, as one by one the stars flashed out in the domed vault above, the almost oppressive stillness of the night was broken by the myriad infinitesimal sounds of animal and insect life. Yet in the glade below us all was hushed. Then the whining cries of the jackals and the eerie wails of the hyænas rang out through the still, dark air, drawing nearer and ever nearer to their evening feast, until we could hear the low patter of feet on the hard ground beneath us. Then in the east, all glorious, arose the queen of night, the radiant tropic moon, which we in England know not, and flooded all the world of blackness with her pale waves of limpid light, till we could see below the slinking, shadowy forms of Nature's scavengers, flitting to and fro betwixt the light and shadow. Silent we lay and watehed them, while the pale light waxed and grew, and then all of a sudden there was a flutter of excitement, and out into the moon-lit glade walked a large leopard. In a light when one could read small print with ease, his markings stood out clear and distinct, and we watched him 


\section{0}

\section{LEAVES FROM AN AFRICAN GAME-BOOK}

as he stalked round the body, the hyænas, scattering before him, snatched a bite or two, and glided away into the darkness. Half an hour later we heard the roar that told of his kill, away in the direction of the camp, and the next morning we found the half-eaten body of his vietim, a full-grown Grant's gazelle, near the river bank.

Another hour of silent watehing, and suddenly a panic seemed to seize the beasts below, and they slunk away into the deep shadows as from the undergrowth close at hand boomed forth the awe-inspiring notes of a lion's roar. At a distance of a few feet the roar of the lion is about the most nerve-shaking noise I know, as the great volume of vibrating sound peals echoing through the quivering air, and seems to fill all space with palpitating waves of sonorous reverberation. Safe as we were on high, I pushed forward my rifle, casting a glance at the index pin on the dial to see that it was loaded.

The roaring continued and was taken up by a chorus from all sides as the lions gathered about their feast, and I drank in a succession of new emotions with every booming note. Suddenly the roaring ceased, and into the open space beneath our tree glided a small lioness; she halted for a moment near the body and then passed on into the blackness 
on the far side of the glade. Then there was a rustling in the bush, and out into the moonlight stalked a huge maned lion; with a single bound he reached the body of the rhinoceros, and stood with his fore-paws resting upon it, motionless. In the pallor of the full moon's rays he seemed enormous, the size of a fullgrown heifer, and snow-white, the colour of bleached linen. As he stood motionless, a glorious sight in the sheer freedom of unfettered strength, up went my rifle and I pressed the trigger. A metallic "click" sounded, and that was all. Up went the lion's head, and he gazed into the tree whence the noise proceeded, while I tore open the rifle, thinking unprintable thoughts-to find that there was no cartridge in it! At the click of the lever, which sounded in the stillness like the clash of cymbals, the lion leaped forward and was swallowed up by the darkness, and though we watched till dawn-with a loaded rifle this time-not another sign of lion did we see, though the roaring continued all around us.

I had loaded the rifle before leaving camp, but, as we climbed the tree, Mahomed Adan had unloaded it in case of accident, as it had no safety-catch, and on settling down in the mâchan had either assumed that I had reloaded-as he said, or had forgotten all about it-as I suspected. Anyhow, the mischief was 
212 LEAVES FROM AN AFRICAN GAME-BOOK done, and I found it hard to forgive him, excellent fellow that he was : indeed, it was his very excellence that led me to leave to him so important a matter, which of course it was my own business to attend to. However, this was the only occasion during his five years' service with me on which he made a mistake, and set against his manifold excellencesthoroughness, carefulness, and pluck-it must count for nothing.

Nevertheless, the lion was lost, and news from the main camp next morning recalled me there, never to return to the place where I had my two easiest chances at lion and lost them both. 


\section{CHAP'TER XVII}

THE ETHICS OF SHIKAR

IT is a matter of some difficulty to write on the subject of shikar in a general rather than in a concrete sense, and, once one begins to give way to the inherent tendency to "yarning" which is latent in every man, it is difficult to know exactly when and where to draw the line which shall separate interest from the boredom born of excessive reiteration. There is a considerable amount of sameness about all shikar stories, and we cannot have hairbreadth escapes every day we go out with a rifle. Further, as I think I have said before, the stalk, which is the most enthralling part of the hunter's vocation is-to say the least of it-not wildly enthralling in cold print. Interesting and instructive to the keen shikári it is indeed, and any such need not go beyond Mr. Jackson's admirable description in the Badminton "Big Game Shooting," with a few points from Captain Dickinson's "Big Game Shooting on the Equator," to gain all the technique he needs. To the ordinary reader, 
however, the technical points of big game shooting, like those of any other game or sport, are apt to prove somewhat void of interest, and even from the expert the reading of such points is more apt to produce rather a knowledgeable acquiescence, than to provide him with any fresh "tips."

It seems to me that I have in preceding pages dealt sufficiently with the concrete in big game shooting, and that to do so further would be to run the risk of over-stepping the above-mentioned dividing line; but $I$ should like, before relegating shikar to a back place, to touch lightly on the ethics, or what I may term the unwritten law, of big game shooting. I have, to a certain extent, dealt with this subject in a previous chapter, but $I$ think that a further short disquisition on so important a subject would not be out of place.

To commence with, one should always keep it firmly in memory that one's game is entitled to fair play. Possibly I am out of date and utterly mistaken, but I hold, and hold very strongly, that any animal which, with the assistance of white professional hunters, native trackers, and numbers of armed retainers, is marked down, isolated, and brought not only to the rifle-muzzle of the "sportsman" who is paying for it all, but to the rifle-muzzles of 
a bevy of armed men white and black, who are at the call of their employer, should his shot go amiss-any such animal has, I say, no more a fair chance than has a single unarmed man who walks into the middle of a troop of maneating lions or a herd of vicious elephants.

In India the density of the jungle may or may not render tiger-shooting from mâchan or elephant-back necessary. As to this I express no opinion, but in Africa $\mathbf{I}$ consider that riding down unwounded game over open country, or shooting driven game from a mâchan, or sitting up over a kill in a mâchan, is hardly sporting. As regards the first $I$ have never myself done it, but the possession of a horse will often contribute to the putting out of its misery a wounded animal, which otherwise might have escaped. Here the employment of riding down one's game is not only not unsporting, but commendable.

I myself must plead guilty to both counts of the second indictment, but only once on each count, both of which episodes $I$ have related in former chapters. In the case of driving buffalo up to a mâchan the circumstances were altogether exceptional. Every other means of getting at them had been tried and had failed, and not only was there not the entire absence of risk usually attendant on this form of sport, but, as I have tried to show, the 
danger to my companion and myself was considerably greater than we would have incurred in tackling a small herd on foot. As regards the sitting up over a kill, I admit that I was going against my principles, and my only excuse must be that I was at that time mad keen on getting a lion-which, however, I did not succeed in doing. I have often sat up over water-holes, etc., both before and after the episode alluded to, but I have never fired a shot, and have contented myself with watching and observing the habits of such animals as have come under my notice.

I hold that in big game shooting man and beast should be as equally matched as possible, and this is, in my opinion, accomplished by the shikári setting forth on foot and meeting his quarry-dangerous game, be it understood-on his own, unaided by armed retainers and the like. The beast has strength, instinct, ferocity, sense of smell, activity, and half-adozen other advantages on his side; man has intelligence, cool wits, and his rifle. The balance is pretty nearly equal, the advantage being with the biped. With non-dangerous game the shooting is merely the culminating incident of the stalk, wherein man pits his intelligence, his woodcraft, his reasoning faculties, and his self-control, against the tireless watch for enemies in every shape, and the 
wonderful instinct with which brute creation is endowed. Pursuing one's game in this way not only gives the quarry a chance, but it educates and develops the hunter. One naturally commences one's shooting under the ægis of a native tracker, more or less proficient; few white men ever learn to dispense with him altogether, but one can learn much of his craft and absorb much of his knowledge. By treating every stalk, every minute of observation, not only as a pleasure, but as a lesson, one can improve one's woodcraft and one's knowledge of animal life thousands per cent., and in a surprisingly short period of time one can pit one's own knowledge and individuality, and not some other fellow's, against the game. Gun-bearers one always has, but they should be exactly what their name denotes - the bearers of guns, and any gun-bearer who so far forgets himself as to fire, except in cases of the gravest necessity, should be directed into some other sphere of utility with the least possible delay. I myself have had my life saved by a gun-bearer, and that occasion was the only one on which he ever fired a shot.

Therefore, not only is it fair to one's quarry to rely on oneself and to take them on singlehanded, but one's own enjoyment is rendered so infinitely keener by so doing, that, even 
considering oneself only, it is worth one's while from a selfish point of view to be able to take on any game one meets single-handed. Would one rather watch Vardon play golf, or play golf like him ? The answer is incvitable and the inference obvious.

Then again, it should be an instinct never to let a wounded animal escape, to endure abominable misery and pain, and eventually die, as he almost assuredly will, a painful and lingering death, whether from the injury itself, or the putrefaction of a dirty and undressed wound, or at the hands of the jackals and hyænas. To allow him to do so is animal torture of the worst degree, and one should endure fatigue, hunger, thirst, heat or cold, in the endeavour to finish off a wounded animal. Keep on his tracks, looking not to right or left, and, resisting the temptation of ever so delectable a trophy, should it be encountered, don't rest or spare yourself till you have put him out of his misery. Further, it is not only fair to the game, but infinitely more comfortable to oneself in avoiding long, stern chases after a wounded beast, never to shoot until one is certain of killing. If the stálk goes wrong to-day, try again later onthere's a lot of game in Africa, and plenty of big heads. Any fool can, and some do, open long-range fire into a herd of game. Such 
deserve the Mikado's scheme of making the punishment fit the crime.

Again, kill sparingly; one or two good heads of a species are enough for any man. The "game hog," the hunter for blood, the man who hunts for the pleasure of killing, is verging on a form of mania, and should be forbidden the use of any lethal weapon. No words can condemn him strongly enough. As a schoolboy he probably tortured animals, as a man he probably enjoys bcating a horse or a dog. He and his kind, together with the professional hunter, arc the cause of the extinction of many species that formerly existed. He gives me a bad taste in the mouth-so let us pass him by, and if in real life we meet him, let us discountenance him as strongly and as sternly as we can.

Such are the main points of the etiquette of big game shooting. Put briefly, they might be tabulated somewhat as follows:

1. Give the animal a sporting chance. Take him on yourself off your own bat, and don't hire a lot of people to do the donkey-work and look after your wretched self. Do your job on your own.

2. Never let a wounded animal escape. Never shoot till you are practically 
certain of killing, and if by any chance you don't kill, spare no pains in making a clean job of it.

3. Never shoot a smaller "head" than you already possess, and with a new species don't shoot the first head you see-there are probably bigger ones coming along behind. Two or three good heads of a species are enough for any man who is not a glutton, and a pair of glasses and a camera can be employed in a practical stalk far more profitably than a rifle.

4. Never shoot a female with young, and very rarely shoot one without.

The above rules do not, of course, apply in their entirety to vermin such as crocodiles or any man-eater.

By sticking to some such rules as these, a man will have more leisure to observe and study the ways and habits of wild game, and will not only know infinitely more of natural history, woodcraft, the customs of wild creation, and, in short, the whole art of shikar, but will, I venture to prophesy, enjoy his sport far more than he who leaves all its essentials in other hands than his own.

Once in the Congo Free State I was intro- 
duced to M. le Commandant X, "who," said my introducer, "est un grand chasseur, he has poison ten lions." At all events, thought I, he did the poisoning himself.

Let me wind up what I fear many readers will consider an unprofitable chapter of reiterations-"for," says the sportsman, "every shikári knows all that," and the other fellow either skips it or says "Damned rot"-let me wind up this chapter, I say, by giving a bare list of the localities where I personally had my best sport in Africa. All this may possibly be changed now that shooting has become so widespread there.

1. The Anglo-German Boundary from Lake Victoria to the Guaso Nyiro River. Absolutely the finest shooting country I ever struck, and quite untouched when I left Africa. The game there includes elephant, rhinoceros, hippopotamus (in Lake Victoria), lion, buffalo, leopard, ostrich, roan antelope, Jackson's and Coke's hartebeeste, topi, zebra, eland, wart-hog, impala, Grant's, Thompson's, and Roberts's gazelle, oribi, klipspringer, water-buck (both species), bush-duck, duiker, reed-buck, wildebeeste, giraffe, Oryx callotis, and Waller's gazelle.

It can be reached either by the route described in Chapter VII or from Port Florence, but the country being uninhabited, careful 
arrangements for flour, etc., for safari would have to be made. Donkeys would probably be the best transport, and a good guide, preferably a Masai who had accompanied the Anglo-German Boundary Commission, a necessity.

2. The White Nile from Wadelai to Nimule. Elephants used to swarm on both banks, and various other varieties not obtainable elsewhere, such as white rhinoceros, the Congo buffalo, Mrs. Grey's kob, in addition to the more common kobus kob and harnessed antelope, with all the common species, can be got there. It is an unhealthy country, and the dry scason is the only time to shoot there.

3. The banks of the Sondo River and the country between its bend where it turns off to flow into Lake Victoria and the railway used to hold a considerable number of elephant and a few buffalo. Easily reached from either Kericho or Kibigori. The Kosova inhabiting the left bank were hostile in my day.

4. The 'Uasin Gishu Plateau used to be full of game, but I imagine it is getting shot out, and covered with settlers.

5. 'The Mau foothills as described in Chapter VII.

There were, of course, lots of fine shootinggrounds which I never had the luck to visit. 
THE SPORTSMAN'S PLATFORM 223

Of those that I did go to the above were about the pick.

Since this chapter was written I have had the good fortune to read Major Stevenson Hamilton's admirable book, "Animal Life in Africa." In this work he goes very fully into what I have termed the ethics of big game shooting, and deals far more completely and graphically than I could hope to do with the question. It is well worth the while of every big game hunter, whether experienced or embryo, to study his pages, and the man who acts up to "The Sportsman's Platform" which he gives will be a sportsman, as distinct from an animal-killer-and oft-times torturer. 


\section{CHAPTER XVIII}

\section{SPORTS AND PASTIMES}

Besides big game shooting, the sport par excellence of Equatorial Africa, that country provides almost every other form of outdoor sport-bar skating-that can be mentioned. Cricket, football, hockey, golf, and tennis are some or all of them obtainable at every station in the twin protectorates, and inter-station matches were common features during the latter days of my time in Africa. There were no racquet courts in existence, but these are bound to come, if they have not already done so.

At Nairobi-which is, of course, in my opinion, the pick of all African stations, we used to get at certain seasons good quail and sand-grouse shooting, while guinea-fowl and jungle-fowl are common in most places. Duck and snipc are obtainable in certain localities, and the chapter entitled "To Naivasha after Duck and Snipe" in "Big Game Shooting in the Equator" gives an excellent description of this particular form of sport. 
The devotees of "the gentle art," also, are not neglected. Trout have been put down in many of the upland streams, and are, I believe, doing excellently, while the Nile from the Ripon Falls to Nimule affords excellent sport with the "baggara," which run up to eighty pounds-possibly more, but the largest I have heard of was an eighty pounder. Just below the Ripon Falls, at Jinja, the fisherman can have a first-class time.

At Nairobi polo is-or was-played two or three times a week, and if at its inception it was hardly up to tournament form, it has probably improved out of all knowledge by this time.

Horses do well at Nairobi. There is no fly, and although horse-sickness exists, and at times is very bad, there had only been, up to the time of my departure, one case on the high ground where the military lines and the majority of the residential bungalows were situated; and that one animal had only a few days before come up from the lower-lying township. With mosquito-proof stabling and ordinary precautions, one ought to be able to be practically immune from this disease.

In addition to polo we had pig-sticking at Nairobi, which, although not as exciting as the real thing in India, and somewhat marred by the tendency of the wart-hog to go to ground 
in his own or any other vacant burrows he can find, is nevertheless quite good sport, and with a careful " bandobast" for earth-stopping, etc., might be considerably improved. If not so fierce as his Indian cousin, the wart-hog will nevertheless put up a determined fight when run down in the open, and can, if he wishes, turn quite nasty. It is rather curious to see him going to ground, as unless he is very hard pressed he invariably turns about and backs in-I suppose the earths are too narrow to turn in, and piggy prefers to face the direction from which danger may arrive, rather than to present a defenceless posterior to the danger-zone. There is a story extant of a certain A.D.C. of sporting proclivities who, when the hard-pressed pig had-contrary to custom-advanced into his earth, delved downwards after him, till all that was left outside the burrow were two boots, each tightly grasped by two lusty fellow-sportsmen. For the veracity of this I do not vouch.

A similar incident did however in fact occur to an ardent follower of the Nairobi Hounds, who, moved to desperation by sounds of conflict in an earth, executed a subterranean dive and-anchored once more by his feet in the grasp of master and whips-extracted by the stern a hound at grips with the jack.

The Nairobi Hunt, in fact, has in its chroni- 
cles episodes undreamt of in the annals of the Quorn or the Meynell.

Among such may be instanced the occasion when hounds ran their jack amongst the tombs of the Nairobi graveyard, and finally pulled him down near the scene of a funeral then in progress, much to the indignation of the officiating Padré. Also the day when, after running for a short distance in long grass, the unorthodox shout of "Ware Lion" came back from the first-flighters, and the anguished master and whips were only barely successful in whipping the pack off two lion which they had been running.

Not the least of the attractions of Nairobi were the two annual race-meetings-now I believe increased in number-which were the occasion for " weeks" which comprised dances, dinners, lotteries, theatricals, and in fact a general "beano!" As I write I have before me the cards of several of these meetings, and for the benefit of racing men I quote one in extenso. 


\title{
FIRST DAY
}

\author{
First Race \\ THE NJORO CUP \\ (2 miles over 8 flights)
}

A hurdle handicap race for all horses. A Cup presented by Lord Delamere with Rs. 100 from the fund. Second to receive Rs. 50.

1. Capt. H. A. Wilson's b. i. c-b. The Count 4 years 9.7

2. Lt.-Col. Harrison's - br. s.a. m. MARY aged 11.7

3. Mr. Handcock's $\quad$ gr. Som. g. BoNes aged 9.7

4. Mr. L. Macnaghten's gr. i.c-b. g. Connnthlan aged 9.7

5. Mr. B. Eastwood's . b.i.c-b.g. The Sarnt 5 years 9.7

6. Mr. A. M. Jivanji's . bl. i. c-b. h. Monindi aged 9.7

7. Hon. R. B. Cole and

Mr. Clutterbuck's ch. aust. g. Bycoula aged 11.7

The Njoro Cup now resides among the Wilson family plate.

Second Race

\section{THE KING'S AFRICAN RIFLES CUP}

\section{(About 7 furlongs)}

A Challenge Cup value 60 guineas, presented by the officers 3rd K.A.R. open to ponios the property of officers of any battalion of the K.A.R. Ponies 14.2 and under. W.I. and class allowance. To be hold for 12 months. Winner to recoive entry fees.

1. Lt.-Col. Harrison's . br. o. m. Bella 14.1 . 11.2

2. Lt.-Col. Harrison's . b. a.m. SHeIkr 14.098 .4

3. Capt. Jenkins' - b. i. c-b. JiNks 14.0 . 9.0

4. Capt. Nelson's b. o. a.c-b. TANOA $14.0 \frac{1}{2} 9.2$

5. Capt. H. A. Wilson's br. aust. m. Speck II. 14.010 .5

$\begin{array}{llll}\text { 6. Major H. A. Walker's } & \text { br. aust. g. ST. MAUR } & 14.2 & 11.7\end{array}$

Once more the "green, red slceves and cap" was successful. 


\section{Third Race \\ THE PONY HANDICAP \\ (About 6 furlongs)}

For ponies 14.2 and under. A Sweepstake of Rs. 15 with Rs. 100 added. Second, Rs. 50 .

1. Mr. C. Clutterbuck's ch. aust. m. GLaDys $14.2 \quad 8.4$

2. Lady Delamere's . ch. aust. m. KATHLEeN $14.2 \quad 0.4$

3. Hon. Charles Craven's br. e. h. Wink 14.1ł 10.10

4. Major H. A. Walker's N. aust. g. St. MaUR 14.29 .8

\section{Fourth Race}

\section{TURF CLUB STABLES}

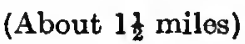

Of 100 sovereigns, of which 50 sovereigns presented by Lord Delamere. Second to receive 10 sovereigns from the fund. For all horses imported into East Africa from any country within the previous twelve months, i.e. after July 29, 1905, with the exception of that part of Africa comprised between latitude $18^{\circ} \mathrm{N}$. and $12^{\prime} \mathrm{S}$.; weight for age and class vide advertised conditions. Four horses to start or no race.

1. Hon. R. B. Cole and

Mr. Clutterbuck's . br. e.m. Raritar 11.0

2. Mr. R. Seymour's • b. aust. g. Reverberation 11.3

3. Lord Warwick's - br. Som. g. HaMisI 8.3

4. Lord Warwick's $\quad$ gr. Som. g. JuMA $\quad 8.2$

Fifth Race

\section{THE ARAB HANDICAP}

(About 6 furlongs)

For Arab ponies 14 and under. First, Rs. 200. Second, Rs. 75.

1. Messrs. Muirhead and

Dunman's . . b.a.h. CALIPH 14.039.0

2. Mrs. Boileau's $\quad$. b. e. h. The BABY 14.08 .7

3. Hon. Charles Craven's ch. a. h. Governor 13.2\% 8.10

4. Hon. Charles Craven's b. a. m. We Woman 13.349 .0 (lato J LOOSL) 
Sixth Race

A match for Rs. 150 a side (about 1 mile)

$\begin{array}{llllc}\text { Lt.-Col. Harrison's . } & \text { - } & \text { b. a. h. } & \text { SherkH } & 10.8 \\ \text { Capt. Nelson's } & \text {. b. e. a. ob. h. } & \text { TANGA } & 9.11\end{array}$

\section{Seventh Race}

THE SETTLER'S PLATE

(About 2 miles)

Rs. 600 , of which Rs. 300 presented by Lord Cardross. First to receive Rs. 525. Second, Rs. 75. For ponies 14.2 and under W.I. and class. English, aust., and S.A., etc., 14.2 to carry 11.7.

1. Mr. C. Clutterbuck's ch. aust. m. Gradys 14.211 .7

2. Lady Delamere's . ch. aust. m. Kathleen 14.1 11.0

3. Messrs. Muirhead

and Dunman's . b. a.h. CaIJPH 14.0 9.11

4. Lt.-Col. Harrison's - b. a. h. SHEIKH $14.0 \frac{3}{4} 9.11$

5. Capt. H. A. Wilson's. br. aust. m. SPECK II. 14.010 .5

$\begin{array}{llll}\text { 6. Major H. A. Walker's b. aust. g. ST. MAUR } & 14.2 & 11.7\end{array}$

The second day's programme of this meeting was similar to the first, and comprised a 5-furlong Novice race of Rs. 200 for ponies 14.2 and under, W.I. and C. A selling plate, 5 furlongs, Rs. 300 for ponies 14.2 and under to be sold for Rs. 600, W.I. and C. An open Arab race $1 \frac{1}{2}$ miles, 10 stone and usual penalties for previous wins, Rs. 200. A horse handicap of Rs. 300 over $1 \frac{1}{2}$ miles, where the I.C-B.G. The Count defeated, after a great race, the English and Waler racers Raritan and Reverberation, the former of whom afterwards went 
to India in the ownership of Captain Barrett, 15th Hussars, and the latter of which was the winner of twenty races in Australia. A 4furlong scurry for all ponies 13.3 and under of Rs. 200. A welter weight one mile race of Rs. 100 for ponies 14.2 and under. A 5-furlong consolation race Rs. 50, sweepstakes with Rs. 150 added.

From the above somewhat lengthy extract it will be seen that not only was the class of horse-flesh good, but that the stakes were well worth winning, to say nothing of the fact that the racing was entirely amateur, and therefore infinitely more sporting than any racing $I$ have elsewhere encountered. 


\section{CHAPTER XIX}

" SKETCHES"

Dawn! Dawn on the forest-clad summits of the Nandi lills. Minute by minute the eastern sky lightens, and the cloud-banks are gilded by the rosy advent of the sun. The shadowy masses of an instant ago take form and shape, and stand clear-cut and revealed as the sombre drapery of night is torn away. Slowly the gloom dissipates, and the raw chill breeze of dawn causes a shiver to ripple down the rank of men standing shadow-like against the lead-coloured background of dew-sodden bush. Silent and motionless they stand, one hundred black soldiers and their white officer, tense, silent figures that might well be cut from stone were it not for the gleam of the restless eyes and the stcam of their smoke-like breath hanging on the moisture-laden air. They have left camp an hour before midnight, and have threaded the dense darkness in an effort to surprise at dawn the territory of a recalcitrant chief and his warlike followers. Drenched to the skin with the heavy dew and 


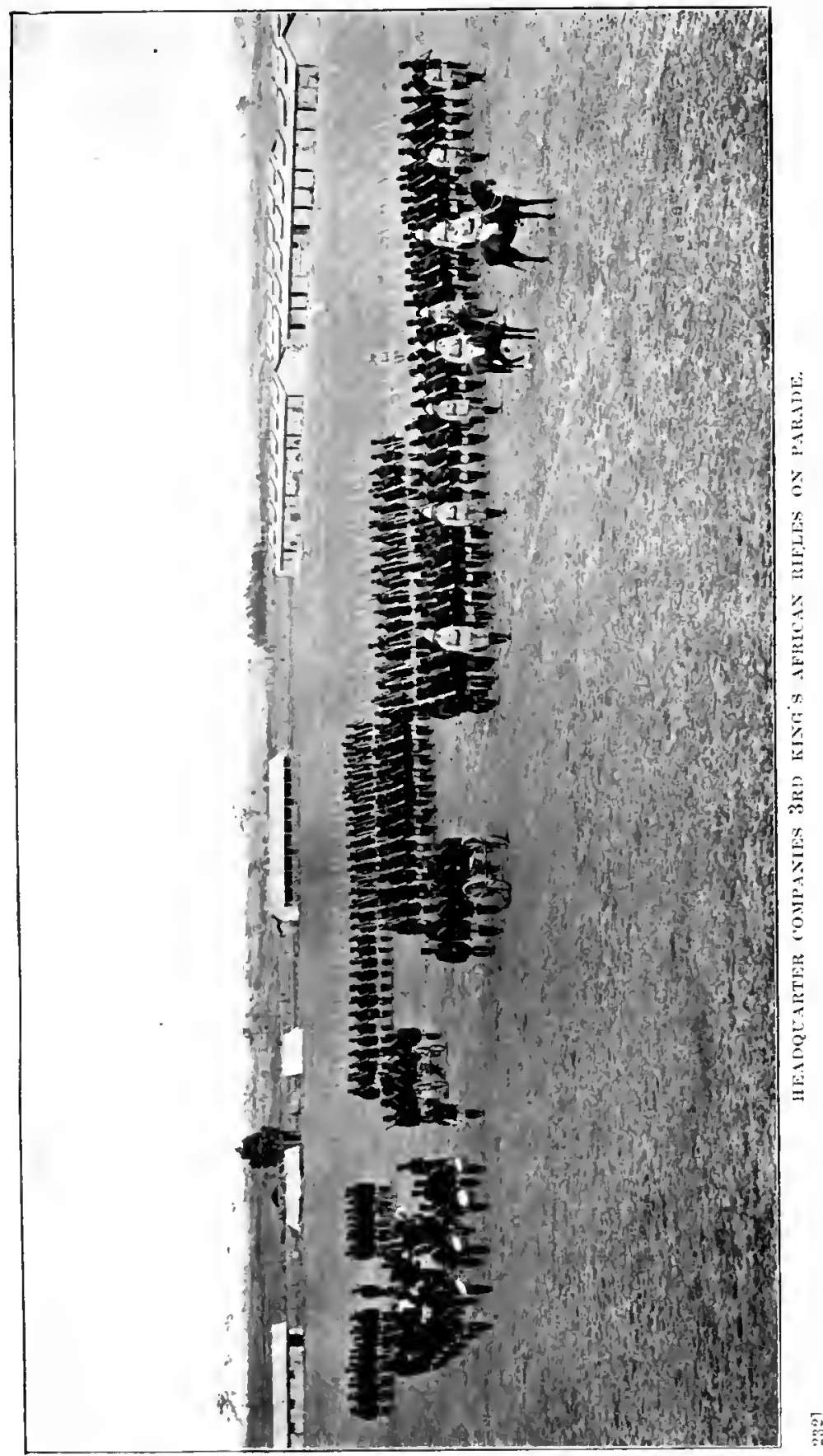




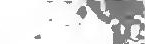


by rivers forded in inky blackness, they have reached their destination at the appointed time, and, halted under cover, await in momentary expectation some sign of the attack of their co-operating columns.

Still deep silence reigns. Each instant the mists of morning are rolling back before the fledgeling rays of sun. In the valley before them such of the enemy's huts as are visible are wrapped in a profound stillness. Not a thread of smoke rises to join the low-lying cloud-bank. No sign of life anywhere betrays itself. A word from the offiecr, and two parties detach themselves from the main body and vanish-silent, gliding shadows-into the reeking grey sea of bush to right and left. The officer's field-glasses are glued to his eyes as he peers anxiously through the ever-lightening air.

A great rift is, of a sudden, torn in the walls of mist, and, like a rent veil, they part asunder and the sun-rays flash far, far below upon the silver sheen of a mighty lake-Victoria Nyanza, greatest of inland seas. The clouds close once more, and, like the vision of a dream, the radiant lake has vanished. In the deep silence rings out the distant music of a mountain stream, swollen by tropic rain. In the utter stillness the tiny sound dominates the universe, and seems to flood the ear and numb the brain with roars of thunderous clamour: higher, 
deeper, louder it grows as imagination plays upon the brain, until from the near distance rings out sharp and sudden a single rifle-shot and its responsive death-shriek : another shot, two, three, a whole volley, and the sleeping world springs to sudden life (with sudden death in grim proximity), and the savage is learning once more the lesson that the white man is and must be master, and that the king's law is made to be obeyed.

High noon! The scorching sun beats down from the cloudless blue in all its pitiless strength upon the barren rocks and sandy soil of the Great Rift Valley, soaking the country's rugged face with blistering liquid heat. Not a breath of air rustles the parched spear grass or the stunted acacias, for the morning's breeze has long since died away and left the parched land to the sole dominion of King Sol. The thirsty sun-cracked earth gasps waterless, and, powerless to resist the fiery rays, soaks up the heat like some gigantic sponge, and burns the foot upon it. The lava and pumice, hot as fire, crackle beneath the tread.

Overhead, high in the unbroken blueness of the sky, a single black spot hangs motionless between earth and heaven : it is the everpresent vulture, watching expectant for the 
feast brought by his grim ally, Death. Save for the quivering heat-haze, the only movement in the picture is the straggling safari. The long line of laden carriers, broken here and there by the khaki-clad figure of a native soldier, moves slowly forward in single file in the direction of the long green ribbon of distant foliage which marks the course of the Guaso Nyiro River: the only water nearer than the springs in those far-off hills which show blurred and ill-defined through the shimmering heat. Thence, since three hours before dawn, the caravan has marched, heading for the river. A long march, but in these arid wastes each march's length is determined by the presence of the vital fluid. In the cool of the morning the miles have slipped past, but now the caravan toils painfully forward, the carriers groaning under their sixtypound loads. At the head of the string of men and animals walks a European-his pony led behind him. He is the subaltern in command of the half-company, the local representative of His Britannic Majesty. All the rest of the column are of varying shades of colour, from the saffron Somali to the coal-black Nubian.

Slowly they move forward; for the caravan's pace is that of its slowest member, and the bare feet of the natives suffcr at each step on the sharp, hot, sun-baked rocks. 
Beneath a clump of somewhat larger acacias a halt is called. Loads are flung down and tired limbs are stretched, while the last few drops of water in the water-bottles are drained. Inert forms stretch themselves in the scanty shade, and slack muscles, relaxed from the past toil, strive to gain rest against that still to come.

The halt is brief, for tired muscles stiffen quickly, and loads are once more raised and the weary mareh resumed. Only a few more miles now, and the haven of rest is reached. Twenty yards ahead of the earavan walks the white officer, his Sudanese orderly in close attendance. The tout ensemble of His Britannic Majesty's representative reminds one far more of a bushranger or some kindred desperado than of the generally accepted type of "gilded popinjay." The big (and dirty) sun-helmet shades a face bronzed with the sun and sporting a three days' growth of beard. A ragged khaki shirt, short-sleeved, and wide open at the neck, with its clip of brass cartridges on each breast, a patched pair of khaki "shorts" ending above burnt and thorn-scarred knees, and putties over heavy nailed shooting-boots, with a rifle on shoulder, complete his " uniform." His thoughts are as unpoetical as his appearance. Briefly, they centre round one subject-drink. In imagi- 
nation, the crushed ice clinks against the clouded tumbler, striking cool to the hand that holds it. A slice of lemon crowns its amber contents, and displaces the two seductive straws. In short, his whole mind is centred upon that most refreshing of beverages, a sherry cobbler.

A touch on the shoulder recalls him from sensuous day-dreams of cool "bars and places where they drink" to the realization that, hot, parched, and sweating, he is tramping Africa's torrid face, grimy with dust and sweat, footsore, thirsty, and tired. A whispered word in Arabic, and the Englishman glances quickly towards a confused cluster of beetling rocks on his right. There, on the topmost crag, placidly surveying the string of wearied humanity, stands a fine bull oryx, the only other living creature in sight. The white man drops to the ground, whilc at a word from the orderly the caravan plods slowly on. The beast still stands motionless, watching its hereditary foes. All its instinets cannot save it, since it has failed to see that one amongst them has stopped. Were the whole caravan to halt every man of them knows that the bull would take to his heels. The rifle is raised : "crack" sings the cordite, and the oryx comes pitching down from his crag. Ten minutes sees him cut up, and the tired 
carriers are nevertheless not so tired that they refuse to add to their loads that greatest of luxuries-meat.

The sun has crossed the meridian, but the heat seems rather to intensify than decrease. But by now the river is close at hand. Tired men brace themselves and step out with renewed vigour. Animals, scenting the water from afar, show signs of restlessness. But a little farther, and the stream's outlying fringe of greenery is reached. Discipline should know when to relax. This is such a time. Loads go down, animals are turned loose, and in a chorus of joyful shouts men and animals, black and white, break into a run and dash forward to the river's brink.

Ten minutes later our friend the subaltern, stripped to the buff, stands neck-deep in a shady pool, absorbing liquid, sponge-like, at every pore. As he watches the tents arising in the little clcaring, and the smoke of the camp fires rising slowly upwards in its grey, soft spirals, and hears the hum of voices and the bustle of the camp, he reflects that Africa isn't after all such a bad place, and that he can perhaps exist for another year or so without treading the pavements of Piccadilly and Pall Mall.

Evening ! A bare, craggy hill rising abruptly 
from the undulating plain that slopes gently upwards towards the foot of Mount Kilimanjaro. In the green grove nestling on the bare blackness of the hill-side are the paler green and the white of tents, and the scarlet pinpoints of the glowing camp fires. At the open door of a tent reclines, stretched at his ease in the longest of deck chairs, our subaltern friend, his costume négligé in the extremepyjamas, in a word. On a camp table at his elbow stands the longest of tumblers, coloured the palest of amber with the ubiquitous whisky and sparklet. A black and bubbling pipe is gripped between his teeth, and an expression of beatific content pervades his countenance, for to a hard day's successful hunting have succeeded the comforts of bath and restful quiet for limbs pleasantly and healthily tired, with the prospect of dinner in the immediate future.

Before him stands the slight, sinewy form of a Masai elmoran, with whom details of the next day's sport are being discussed. The regular features and negligent, muscular poise of the bronze nudity call up memories of the statues of ancient Greece. Presently, with a gleam of white teeth, the warrior turns and swings off round the tent, and the white man lapses into day-dreams. Soon, however, he is recalled to earth by the advent of a string of 
porters, who, advancing through the camp, hurl down their gory trophies at the foot of the spear, which, carrying a tiny Union Jack, is planted in the ground in front of the tent. These are the spoils of the day's hunting-red, gory joints of meat-the luxury par excellence of the African. Two fine heads, an eland and a water-buck, which two orderlies are scraping and cleaning, and two pegged-out skins proclaim whence the feast has come and what has been the day's bag.

The loads thrown down, long, keen knives are produced, and some practical butchery is witnessed upon legs and quarters, and soon heaps of small joints are lying upon the ground ready for distribution. Then from all sides stream soldiers and porters in eager anticipation of the good things to come. At a word from the Mnyema colour-sergeant (an erstwhile cannibal from the Congo Free State, who, his man-eating proclivities of necessity in abeyance, has proved himself a staunch soldier and an excellent N.C.O.), the headmen of messes step out from the expectant crowd, and under the watchful eye of the subaltern receive their fair share of meat, without partiality, favour, or affection. Then, assisted by their eagereyed mess-mates, they bear off their dripping burdens in the dircction of the simmering cooking-pots. In a few moments the heaps 
have vanished, and all traces of their presence have been removed by two hungrily impatient porters, and the subaltern is left alone.

At first his thoughts run idly over the day that has passed: the big rhinoceros seen in the early morning which gave no chance of a shot-hopes of a future meeting; the killa fat zebra-half eaten, with the lions' pug marks all round ; that first shot at the elanda shade too far back, causing a long and weary pursuit in the heat of the day before the wounded bull was eventually despatched; the water-buck, well stalked and clean killed; that herd of impala, led by the buck with the enormous head, seen on the way back to camp and marked down as to-morrow's quarry. All these pass before his mind's eye in a panorama of that dreamy content that Africa begets.

Then, raising his eyes, he takes stock of his immediate surroundings. Above the thin grey smoke-spirals rising from below him gleams the white crest of Kilimanjaro, whose snows are even now borrowing from the setting sun the faintest pink suggestion, while the dark stretch of mountain side and plain, joining those snows to the humming, bustling camp, seems to proclaim in trumpet tones that sense of vastness, of wide, empty spaces, of illimitable 
distance, of solitude from man, but of intimate kinship with Nature, which is the very essence of the spirit of Africa, which one inhales with every breath, which envelops and wraps us about, permeating our very being in that land of dark, mysterious witchery.

As he watches, yielding himself, a willing victim, to the spirit of the land, the glorious mountain bathes herself in each successive colour of the rainbow: the pink darkens and deepens : red, scarlet, crimson, purple-waves of each pursue one another over the virgin crest. Then from the imperial climax of royal purple they die away as they speed on with the dying day. After them follow orange, ochre, gold, saffron, and palest yellow. Then, for an instant of time before night's soft grey mantle spreads itself over earth and sky, comes a brief, strange, silver light, tinged with the softest, faintest, almost phosphorescent green. One by one the tiny star-lamps light up and shine forth over the mute earth, whose all-pervading silence is broken only by the low, murmuring hum of the camp below, and the shrill chirpings of the myriad insects, till on a sudden a bugle rings out Retreat upon the still night air. The subaltern's wandering thoughts fly back to earth as the khaki-clad form of his swarthy colour-sergeant, standing before him, salutes and announces 
"Tamaam"-which, being interpreted, signifies "All's well."

Night! In the silver moonlight, under the myriad twinkling lights of heaven the long canoe, driven by twenty brawny paddlers, cleaves the black, unrippled waters of Lake Victoria. The dark water gives back in a thousand points of light the reflections of the stars above, save only in the canoe's wake, where the broken water lies, a blacker line upon the blackness of the lake, spreading in far-reaching ripples to either side. In the canoe itself the burly black forms of the paddlers swing rhythmically together as they drive the high-prowed craft forward to the accompaniment of a droning boat-song, which rings forth in shrill minor cadences on the night air, whose stillness is broken by the snorts and splashings of a school of hippopotamus on the shore of the dark island mass which looms up on the right of the boat. Forward in the bows a white man reclines in a deckchair, heavily muffled in greatcoat and wrapper, for the night air on the lake strikes chill. The red glow of a cigar proclaims his wakefulness, and an open book on his knee testifies to the brilliance of the tropical moon.

The canoe has come from Entebbe, the capital of Uganda, bound for the station of 
Jinja, hard by the spot where the mighty Nile leaves the greatest of inland seas, and starts, over the famous Ripon Falls, upon its long journey to the Mediterranean. Held up by foul weather, storm-tossed, and almost wrecked on more than one occasion, the voyage has becn long and trying, and now in the still, calm night the journey is being continued, for to-night is December 24, and Christmas Day in Africa must, if human toil or ingenuity can compass it, be spent with men of one's own race and colour.

Hour succeeds hour, and still the canoe ploughs on her way, fresh reliefs seizing each paddle as the tired wielder yields to the strain of the hard work. The cigar has long since died, the book closed, and the white man's head fallen forward in deep sleep. Slowly the air grows colder, till the chill of a sudden grips the sleeper and wakes him with a start, numb to the bone. Stretching his cramped limbs, he rouses himself and looks about him. The moon has vanished, and utter darkness lies upon the water, broken only by the pale glow of the stars. The rowers' song has died away, and only deep, guttural grunts and breath hard-drawn is heard as the tired arms ply the plashing paddles. An involuntary shiver, partly of cold, more of depression, shakes the white man, for the 
gloom and the silence of the grave hang over the darkened world.

Suddenly to the east his eye catches a faint, rosy tinge, and he watches it grow brighter and still more bright. His crew have seen it also, and once more the song breaks forth. Up races the dawn, hot foot, as is his way in Africa, and the canoe, seemingly revivified, leaps forward like some live water beast. The rowers' song grows and swells in volume as their craft swings round a dim, dark headland: and as the point is rounded up leaps the sun, and all the mists of morning melt before his advent, and there in clear sight ahead lies the port. Across the dark waters rings out Réveillé, and up the high flag-staff creeps the Union Jack-Christmas Day has dawned. 


\section{CHAPTER XX}

\section{THE AFRICAN SOLDIER}

During my service in Africa many races were tried as soldiers, with greater and less success. Originally all the Uganda troops had been Sudanese, but the Sudanese mutiny (into the causes of which it is unnecessary to enter here, save only to say that the long-suffering of the mutineers before their original outbreakwhich can hardly be termed mutiny-is too frequently glossed over in descriptions, written or verbal, of the event), and the shortage of material consequent on the closing of the Sudan as a recruiting ground, caused the enrolment of other races both in Uganda and British East Africa to become necessary. Swahilis were and are enlisted in both protectorates in considerable numbers, and once his limitations and lack of intelligence are recognized and legislated for, a good-class Swahili is by no means the worst soldier that wears the British uniform. Very enduring, of fine physique and strength, amenable to discipline, and by no means devoid of physical 
courage, he has his good points in plenty. In the Swahili companies, for the class-company system obtains in Equatoria, many other races gradually began to enlist, principally Wanyamwezi and Wanyema. The former are from German East Africa, somewhat akin in looks, physique, and habits to the Swahili, are the finest carriers in Africa, and can, individually, be made into excellent soldiers, but in bulk $I$ do not think that they are very much good.

The Wanyema, a pagan cannibal tribe from the Congo Free State, where they are enlisted in large numbers, are first-class men. Finely developed, amenable to discipline, extremely plucky, and natural fighters, there is nothing they enjoy better than a "scrap." Their weak point is, however, their absolute bloodthirstiness and their tendency in war-time to revert to the cannibal instincts which they hold in repression in times of peace. On several occasions during the Nandi Expedition of 1905-6, I had to check isolated cases of reversion to man-eating proclivities in a company composed mainly of Wanyema. I remember on one occasion a corporal coming in with his patrol and reporting to me, and puzzling me greatly by appearing to possess a third hand clasping his waist-belt. Investigation produced a black forearm, secreted with the 
exeeption of the fingers clutching the belt. Inquiries elicited the fact that its destination was the cooking-pot, and it was a highly indignant N.C.O. who went empty away.

On another occasion I remember hearing my cook and "boy" chaffing my Mnyema orderly outside my tent, and inquiring solicitously how he prepared a big feed, what were the best parts of the human body, whether it was eaten raw, and with or without blood as a beverage, etc., ete., etc. Simba took it all amiably for a time, but at last began to get bored, and in answer to one of the many questions broke out !- "Do you, oh fools, eat a goat raw or cooked ? do you eat a sheep raw or cooked? do you drink the blood of sheep or of goats? No! Then neither do I eat my food raw, or drink blood. If you were in my country I would quickly show you how men are eaten, but you wouldn't be able to tell any one!"

Apropos of cannibalism, the late Lionel Deele relates how at, I think, Ujiji he was given a particularly succulent dish, which subsequently, in spite of repeated requests, he was unable to obtain again. It was not till considerably later that he discovered that his bonne bouche had been human flesh, a baby to wit.

Neverthcless, in spite of their cannibalistic 
tendencies one would have to go far to meet with a better lot of men to deal with, or find finer soldiers of any colour or creed than the man-eating Wanyema, and for my part I never want to lead better troops.

At one time Somalis were extensively enlisted in the Uganda Rifles, and though I never commanded an entire company of them, a considerable number were drafted into the composite company which I took over after the reduction of the Uganda Rifles and the merging of all the local troops into the King's African Rifles. I know that many soldiers dislike the Somali intensely. Personally, I don't. Possibly in his own country, fighting against his own people, he may be a failure. In the small amount of service I saw with them they always did well, and I believe that in the Nandi Expedition of 1902 a Somali company was tried very high, and did not only well, but excellently.

I am quite aware that they are apt to get wildly excited and out of hand in action, inordinately conceited, intriguing, and apt to be insubordinate in times of peace, but $I$ think that all these faults can be overcome by treating them suitably. Against their faults can be set personal courage, intelligence, far superior to any negro's, and hardly, if at all in many cases, inferior to a white man's, 
and fidelity to an officer whom they know and trust.

Like all uncivilized and semi-civilized races, they do not object to the most rigid severity, provided that it is accompanied by absolute impartiality, fairness, and justice. A fairly safe rule for dealing with such races is, " $\mathrm{Be}$ as severe as you can, almost merciless if you like, when you do punish." It is better to inflict no punishment save a verbal reprimand twice, and then for the third offence give the maximum possible, than to worry and bother with small punishments. Punish either severely or not at all, but with it all be rigidly just.

In my fairly brief acquaintance with Somali soldiers I tried to act on these principles, and I think I can without boasting say with success. When they took their discharge and joined the large Somali trading community resident in East Africa, I found that whenever and wherever I met Somalis, gifts greater or less were invariably produced, and as late as 1905, when, in law-abiding Nairobi, I incontinently flogged a "jungly" newly arrived Somali trader, thereby committing assault and breaking countless sections of the Indian Penal Code, not only was I not haled before the bench, but $I$ received an apology from a leading Somali that one of the members of 
their community should have deliberately startled the pony of the lady with whom I was riding, which was the offence that had caused the beating. With a litigious and intensely conceited race like the Somalis this incident shows, and I fancy that most men who know them will agree with me, that gratitude and affection have a very considerable -influence on them.

With game they are absolutely fearless, and an ex-corporal of my company was my gunbearer to the day of his death, and one of the finest and bravest men that $I$ have ever. known.

The Baganda were at one time enlisted in the 4th K.A.R., but proved lacking in courage in war (though, funnily enough, with dangerous game the average Mganda is as plucky as they make them) and mutinous and troublesome in peace. They are now no longer enlisted.

Kavirondo were experimented with in a company I commanded. They are the best " barrack square" soldiers in Africa, scrupulously clean, hard-working, exceptionally good drills, and giving no trouble in barracks; they are a pleasure to deal with in times of peace. They have never been severely tested on service, but have done well enough in the few small "shows" in which they have taken 
part. Their national reputation for courage is not however high, and I believe that they are no longer enlisted.

We had a Masai company in the 3rd K.A.R., and all their officers swore by them. They were not ultra-smart on parade, but on service were, I believe, excellent; and they are certainly first-class, cheery, open-hearted fellows to deal with.

Just beforc I left we commenced to enlist Nandi; I don't know whether they are still enlisted, but I think, speaking from a pretty intimate knowledge of that race, that they ought to make first-class soldiers.

Of the men of the 1st and 2nd Battalions King's African Rifles-Yaos, Angoni, ete.enlisted in Nyasaland, I personally know but little. They have the reputation of being fine fighting men, and they are certainly smart and well turned out, in addition to being good "drills."

The race that I have purposely left to the last is that which constitutes the majority of the 3rd and 4th Battalions of the King's African Rifles-the Sudanese. The first Sudanese troops were introduced into Uganda by Sir Frederick Lugard. At the time of his administration of the country, Uganda was seething with intrigue and war between the three great parties, Roman Catholics, Protestants, 
and Mussalmans. Lugard's position was precarious in the extreme, and in order to possess himself of troops interested in none of the local questions and upon whom he, as an impartial administrator, could place reliance, he opened negotiations with Emin's abandoned soldiers, who, under Selim Bey, had settled at Kavalli's on Lake Albert. These men entered the Uganda service subject to certain conditions, which need not be gone into here.

By degrees more Sudanese drifted southwards into Uganda, from what had been the Equatorial Province, and as they-as well as the men from Kavalli's-brought their women with them, and as there was no prospect of a return to their own country, small Sudanese settlements began to spring up in Uganda. Later, recruiting in the Sudan was permitted by the Egyptian Government, and after the battles of Atbara and Omdurman, a large number of Dervish prisoners enlisted for service in British East Africa.

On discharge Sudanese soldiers have been given grants of land and encouraged to settle in their adopted country, and by means of these colonies the supply of recruits is maintained.

One hears, when discussing this race, much that is good and much that is bad concerning them, but the bad comes mainly from the 
"old stagers" who were in the country at the time of the Sudanese mutiny. The mutiny is a subject which I do not propose to discuss, but I may safely say-and in so saying I am putting the case of the mutineers as blackly as may be-that all the faults were by no means on one side. The episode is dead and need not be dragged up from the grave, and I have only touched upon it to refute an idea, prevalent in some quarters, that the Sudanese are untrustworthy and prone to mutiny. A knowledge of the real facts of the Uganda Mutiny goes to prove the reverse.

The Sudanese soldiers are recruited from the negroid tribes of the Bahr-el-Ghazal and Fashoda districts : the two principal of which are the Dinkas and Shilluks. As fighting men pure and simple, they possibly have not their equal in the world. Physical fear would seem to have been left out of them in the makingthey simply don't know what it means. They were the pick of the Mahdi's and Khalifa's armies, and were used when any work requiring desperate courage was to hand.

They have the instincts of the soldier, and love fighting for fighting's sake. One of their traditions-and onc that has very many times been carried out in its entirety-is that, if the commander of a force is killed, none of his followers may return until the enemy is ex- 
terminated, and any man returning alive until complete vengeance has been taken is for ever disgraced.

In this connection an amusing story is told. Six Sudanese military police under a sergeant were sent out to bring in a chief who had been giving trouble, and certain of his headmen also. In due time they returned to their station under the command of a private and brought their prisoners-duly collected-before their white officer. Amongst the handcuffed malefactors the European was amazed to see the sergeant. "What is the meaning of this ?" he asked the commando, and the self-appointed leader replied, "Just before we reached the village of the chief Mbombo, this son of a fool lost himself, and for two days we could not find him. He knows that had he been killed we could not have returned, but were bound to be killed in the taking of vengeance. Knowing all this he lost himself. When we found him, by good luck unhurt, we resolved that he should not again be lost, so we shackled him, and, when we had done our duty, placed him with the other prisoners. We pray that the sergeant's stripes may be removed from one so unfitted to wear them."

Under officers that they know and trust, the devotion of the Sudanese is intense. They are not easy to know, and, like most savage 
races, it takes time, the exercise of many qualities-absolute justice and impartiality, tact, discrimination, straightforwardness, and the rest-to break down their reserve and enter their affections. Trust and affection once given, they will follow their officer anywhere and do anything for him. I know no officer who has commanded Sudanese for any length of time who does not swear by them.

They are savages, of course; generally unintelligent, cruel, and bloodthirsty in war, but soldiers by instinct and heredity, loyal, fearless, and reliable. They are nominally Mussalmans, but are extremely lax, and drunkenness is common amongst them. The principal trouble in dealing with them arises from their women, amongst whom exists a passion for intrigue, accompanied by a remarkable proficiency in poisoning-of which, however, it is rare to find a man possessing any knowledge. I only remember two cases where men were reputed-and I think trulyto be poisoners. One of them, a company sergeant-major, nearly paid for his reputation with his life, as in the watches of the night he was pursued from the lines to his officer's house by a crowd of armed soldiers, and it needed all the officer's influence to prevent the men invading his house and incontinently slitting the N.C.O.'s throat. 
Amongst themselves their morals are somewhat lax, but with other races they have nothing to do. The men, it is true, take women of other tribes, but such women enter the Sudanese community, dress as Sudanese, conform to all their habits, and become to all intents and purposes Sudanese themselves. It is, however, considered a deep disgrace for a Sudanese woman to marry or have connection with a man of any race but her own. In the old days death was the punishment for such an offence: and even nowadays I fancy that a woman guilty of this would be a bad subject from an insurance point of view; but such cases are extremely rare, and I myself have scarcely ever heard of one.

I seem to have dwelt pretty extensively on the bad qualities of the Sudanese. That they have bad qualities it is foolish to deny, but they are far outweighed by their good ones. They have a strong sense of honour-not - honour perhaps according to European standards-but honour nevertheless. I have mentioned the point of honour touching the death of a commander. Another trait is to endure pain stoically and without murmuring. In undergoing, for instance, a sentence of flogging no tricing up or anything of the sort is necessary with a Sudanese. No hand need be laid on him. He himself takes off his clothing, 
lies down, face downward, on the ground, takes his flogging without a sound or a movement, rises, salutes, and walks away. Twentyfive lashes with a kourbash (strip of rhinoceros or hippopotamus hide) is, as any one who knows can vouch, no small thing, yet the Sudanese who flinches or cries out under it is disgraced. His life in the lines is purgatory. $\mathrm{He}$ is held to have disgraced his company. None of his companions will speak to him, and-what he feels worst of all-his women forsake him, and he is jeered at and derided by the other women and children. He usually takes his discharge.

The Sudanese may be a low týpe of humanity -a savage, vicious and cruel, and all the rest, but he is a fine soldier, a fearless man, and a devoted comrade. MacDonald's Sudanese Brigade at Omdurman showed to a certain extent of what he is capable in action, but his capacity has never yet been fully shown or even realized-save by the few who know him well. Unlike certain other coloured soldiery who fight under the British flag, he has never been boomed or advertised, but this I know, that there are very few races, white, black, brown, or yellow, that can hold a candle to him as a fighting man. Were I allowed my choice, I know that a company, a battalion, a brigade, or a division of Sudanese, well 
A FINE FIGHTING MACHINE 259

trained and led by British officers, is about the last adversary I should select to meet on the battlefield, for such a force would be about the finest fighting machine that the armies of the world could produce. 


\section{CHAPTER XXI}

\section{THE MASAI}

So much has been written concerning the Masai, that the anthropological student in England doubtless possesses a knowledge concerning them as great as or greater than that of the official or traveller who has studied on the spot the manners and customs of that most interesting, but alas! rapidly decreasing race.

The origin of the Masai remains wrapped in mystery, for their own legends do not carry us sufficiently far back to clear up this disputed point. Many and varied theories have been put forward as to their ancestral descent: they have been classed as Hamitic, Nilotic, and Semitic. Captain Merker, who has had unequalled opportunities of close intimacy with and study of the race, advances in his most interesting work the theory that the Masai are the descendants of the lost ten tribes, in support of which he advances many tales and legends and much folklore, that at first sight appear to substantiate the theory of a Hebrew 
descent. His arguments, however, though plausible, cannot be said to be in any sense convincing; and other authorities, such as Hollis, attach no importance to them. One thing only is certain, that the Masai are not indigenous to the soil they now occupy. Of the many theories as to their origin, the most probable appears to be that their ancestors, at some remote period, migrated southwards from the valley of the White Nile, the main fact in support of this theory being that the Masai language strongly resembles that spoken by the Latuka, a negroid race of the White Nile Valley. There is also a close resemblance between the Masai and the Somali in their manners of life, customs, and habits, as well as in certain words and terms of the language.

The Masai are sub-divided into several sections, all owing allegiance to the supreme chief, Sendao. There are also various independent offshoots of the race, such as the 'Uasin Gishu and the Nguruman, who live in the Great Rift Valley near the Anglo-German boundary. With the exception of the latter section the Masai are an essentially pastoral race, depending for existence entirely upon the flocks and herds, of which they possess a great number. They do not practise agriculture in any shape or form, nor indeed do they eat vegetable food to any extent. 
To-day the Masai are but a shadow of their once powerful selves. The zenith of their power was attained under their chief or "laibon" Mbatien, who, since his death, has been regarded by the tribe in the light of a divinity. This great man, untaught savage though he was, had established so perfect a control over his subjects, that it is a Masai boast to this day that no order of his was ever disobeyed. Shortly before he passed away, Mbatien prophesied the smallpox and rinderpest which decimated the tribe and their herds, and from which they have never recovered, as well as the coming of the white man, with whom he adjured his followers to remain on terms of friendship. The behest of the dying man in all probability saved us an infinite amount of trouble and expenditure of blood and money, since the Masai obeyed to the letter the commands of their dead chief, and have ever since maintained friendly relations with the British occupants of their country. How strangely the prophetic utterances of Mbatien were verified is a matter of history, the plagues of smallpox and rinderpest being followed by the appearance in their country of Joseph Thompson, the first European to penetrate Masailand. It was the custom of the Masai to exact "hongo" or tribute from any person passing through their 
territory, the amount being assessed by themselves. The payment of this tax was supposed to ensure the payer freedom from molestation by the Masai, either within or without their country. ${ }^{1}$

At his death Mbatien appointed his son Lenana to succeed him in the chieftaincy. This led to the secession of a portion of the tribe, notably the Loita section, who rendered their adherence to his brother Sendao, and after considerable fighting between the two factions, Sendao and his following left their ancestral country, migrating to the Kilimanjaro district, to what is now German East Africa. Lenana was supported in his claims by the European occupants of the country, and firmly established his position of paramount chief, which he held until his death, which occurred recently. Under his rule amicable relations have been maintained between the Masai and the British Government. Sendao's people were not, however, so fortunate, and came into constant conflict with the German administration. In the years of incessant warfare, both Germans and Masai sustained heavy losses, which culminated in Sendao returning to British territory with the majority of his following, and acknowledging the suzerainty of Lenana, at whose death Sendao succeeded to

1 This tax is, of course, no longer levied. 
the paramount chieftaincy. An interesting and significant feature of the fighting in the Kilimanjaro district was that, during periods when the country was considered by the Germans to be unsafe for any party of less strength than a company of troops, the English Collector, at the border station of Gaveta, constantly traversed the disturbed districts with no larger force than a single native orderly, and was in no case molested or even subjected to incivility.

At the zenith of their power the Masai raided hundreds of miles in every direction, their war-parties ranging from the shores of Lake Victoria to within a few miles of Mombasa, from the Unyamwezi country to Rendile. I remember, when I was out shooting near the Kavirondo border during the AngloGerman Boundary Commission, being taken by a Masai orderly of mine to a place where he told me that there had been a big fight in which he had taken part as a young man. Sure enough, on arrival at the spot, I found skulls and bones in large quantities, showing where a Masai raiding-party had been at work.

Although they possessed a definite military system based upon the organization, for discipline and command, of the "ip" or company as the tactical unit (its fighting strength varied from sixty to a hundred spears), the Masai cannot be considered ever to have been 
a conquering race in the same sense as were the Zulus. Though they dominated an immense extent of country, the efforts of the Masai were confined to raids into hostile territory, terminating in a return with the spoil to their own land, and in no case do they appear to have endeavoured to establish that lasting supremacy over and eventual absorption of defeated tribes, which stamped with the zeal of genius the exploits of Chaka; nor were Chaka's methods followed in the wholesale wiping out of recalcitrant races. In a word, the Masai, though the predominant race of Eastern Equatoria, lacked both that national administrative spirit and the one great man, either of which influences could have completely conquered and then absorbed into the mother nation the various races which they met in battle. For this reason the Masai, though they have been with justice termed the scourge of Africa, never attained to greater heights than establishing for themselves the reputation of fierce predatory nomads, whose military operations in no case exceeded a series of successful and far-ranging forays, and whose conquests, almost invariably local and not national, stamped no enduring impression upon the habits and customs of the races whose forces they worsted in the field.

A curious feature of the military operations 
of the Masai is reported by Joseph Thompson in his work "Through Masailand." I refer to the non-extension of hostility to the women of the warring tribes. Though continually at war with their forest-dwelling neighbours, the Wakikuyu, the daily intercourse for purposes of trade and barter between the women of the two tribes continued uninterruptedly, both parties realizing that each depended upon the other for the luxuries, if not the necessities, of life.

The social system of the Masai is curious in the extreme, and is undoubtedly one of the principal causes of the national decay. The "lyoni" or boys, armed with herdsman's spears, bows and arrows, tend the flocks and herds of the tribe, and assist the old women in the general work. When a "lyoni" reaches the age of sixteen (approximately) he is circumcised, and attains the dignity of an "elmoran" or warrior. These circumcision ceremonies, which are held periodically, and attended with numerous rites, are occasions of great importance, being frequently followed by warlike outbreaks which enable the newlycreated warriors to "blood" their spears. Similar ceremonies are held for the "ndito" or young girls. The "elmoran" live apart from the rest of the section in " mnyatas" (kraals of their own). Though not permitted to marry, every " elmoran" lives with one or 
more "ndito." Fighting, and fighting only, is the raison d'être of their existence. The "ndito" do no work, all the household duties of the "mnyata" being performed by the old women of the tribe. It is considered a deep disgrace for a " ndito" to bear a child; such an infant is immediately destroyed, as was very frequently the mother also, under the old regime.

Strict abstinence, sobriety, and military discipline are imposed upon the "elmoran." Intoxicants and tobacco are forbidden; and his food consists only of beef, milk, and blood. He may own no property, but his share of the proceeds of any raid is handed over to his father or next-of-kin, to revert to him on his accession to the ranks of "elmoru" (elder). He discards the bow and herdsman's spear of his boyhood and assumes the long-bladed warrior's spear, the "sime" or sword, knobkerry and buffalo-hide shield. He dons the lion's-skin or ostrich-feather headdress, the colobus-tail leg-ornaments, and all the other insignia of the warrior, and takes his place as a man of standing in the tribe. Each " manyata" of " elmoran" is under the leadership of its "leguynan" or captain, and when on the war-path a commander-in-chief is chosen from amongst these "leguynan," who is vested with supreme and absolute military command 
of the force. The "leguynan" is essentially a fighting leader, and has no recognized status in the governance of the tribe in peace-time. However, his influence, backed by the opinion of the class he represents, though theoretically nil, may in actual life prove a potent factor in tribal politics.

At the termination of his fighting career, the "elmoran" lays aside the arms of the warrior and assumes the title of "elmoru," marries one or more wives as his means permit, and takes his place as a man of property in the ranks of the village fathers, who control the destinies of that section of the tribe to which they belong, subject always to the influence of the paramount chief or chiefs. It is at this period he succeeds to any property he may have won as an "elmoran."

It is a curious fact that a nation in which a social system so bizarre obtains could have occupied so dominating a position as once did the Masai. However, the baleful results of their system are now making themselves apparent, and unless some modification is introduced the race is doomed to eventual extinction, ravaged as it is in addition by venereal disease, which, introduced by the coast tribes and Indians, has obtained a firm grip upon the race. It is a sad thought that 
a people endowed with so many fine qualities appears to be inevitably doomed.

In their many intertribal feuds, the Nguruman section was invariably treated by both sides as neutral and left unmolested. The Wakwavi are a bastard race of Masai, and have intermarried so frequently with the surrounding negro tribes that their characteristics are chiefly Bantu ; in addition to discarding many ancestral customs, they have completely lost the warlike character and good qualities of the parent race. They live in scattered settlements to the north of Masailand proper, the principal colonies being at Njemps and Mumias. The 'Uasin Gishu are the remnant of a once powerful section of the Masai. Having quarrelled with the remaining section, they withdrew to the 'Uasin Gishu Plateau, to the north of the Nandi country. From there they attacked their fellow-tribesmen living in the neighbourhood of Lake Naivasha, whom they decisively defeated with great slaughter.

After their defeat these tribesmen reorganized their fighting strength, and, allying themselves with their kinsmen dwelling in the Kilimanjaro and other outlying districts, mustered a formidable force, containing every available spearman of the whole nation. This force marched against the 'Uasin Gishu and 
utterly defeated them, inflicting so heavy a blow that the 'Uasin Gishu as a nation practically ceased to exist. The remnants of the defeated tribe fled into the Nandi country, by the inhabitants of which they were received in a friendly manner. They settled amongst their new friends, in some cases intermarrying with them and sinking their nationality in that of their adopted country, in others forming small colonies or settlements. They appear to have evinced a superiority over the Nandi, for at the present day some of the Nandi chiefs are pure 'Uasin Gishu descent, while the majority of the Nandi blacksmiths are 'Uasin Gishu. Still more interesting is the fact that the chief "laibon" or medicine man, in other words, the supreme chief of the Nandi and their sister-tribe the Lumbwa, are both pureblooded 'Uasin Gishu. Under British administration the 'Uasin Gishu have been encouraged to lcave Nandi and migrate to Eldama Ravine Station, where there is a flourishing colony of them; hopes are entertained of eventually rehabilitating them as a nation. 'The 'Uasin Gishu are a fine, manly race, and arc excellent fighting men, both in open country and in bush, so it is to be hoped that under the care of Government they will flourish and prosper. These three sections practise agriculture; the Nguruman, who 
own no cattle, being entirely dependent upon it.

The Masai do not hunt, although inhabiting fine game country. The only game which they will eat are eland, buffalo, and wildebeeste, the flesh of which they consider to be beef. Buffalo-hides are used for the manufacture of shields, and they also hunt lion for the sake of their skins. Blood, as an article of diet, may sound somewhat gruesome, but it is in reality a very beneficial, and, to the Masai, necessary food, as it serves as a substitute for salt, which they do not possess. The blood is obtained from their cattle, and great skill is shown in bleeding them. Their method is as follows: A ligature is placed above the spot selected for the incision, which is usually in the neck. The incision is made with a specially prepared arrow, which has a thick shaft to prevent over-penetration. When sufficient blood has been obtained, the wound is closed with a plaster of clay and cow-dung, and the ligature removed. The blood is usually drunk hot from the animal, but is sometimes mixed with milk.

In lion-hunting expeditions the Masai display great courage, following up their quarry into swamps and reed-beds. They have a tradition that a lion will never charge home at a man if he shows no signs of flinching, 
but that the slightest movement of shrinking backward will bring the beast on top of him. The Masai firmly believe this, but how true it is it is difficult to say; no white man has yet been found with sufficiently well-strung nerves to await a lion's charge motionless, and so prove or disprove the Masai theory.

The warriors are extremely plucky so long as the fighting is in open country. In bush or scrub they are useless, and in their many raids on their kindred races, the Nandi and Lumbwa, who inhabit mountainous and wooded country, have always been defeated. When fighting in the open, their battles usually developed into a series of individual combats between warriors, and they proved on several occasions their ability to endure very severe loss before giving way. They do not go in to any extent for night operations, but frequently attack at dawn, though seldom appearing to attempt surprise tactics. I have heard it stated that it is their custom to give notice to their foes of their impending attack. I give this legend for what it is worth, but 1 have never come across any evidence in support of it, and I think it must be regarded as extremely doubtful.

Though virtually pagans, they believe in a Supreme God (Ngai) dwelling in the sky, and have many curious and interesting legends 


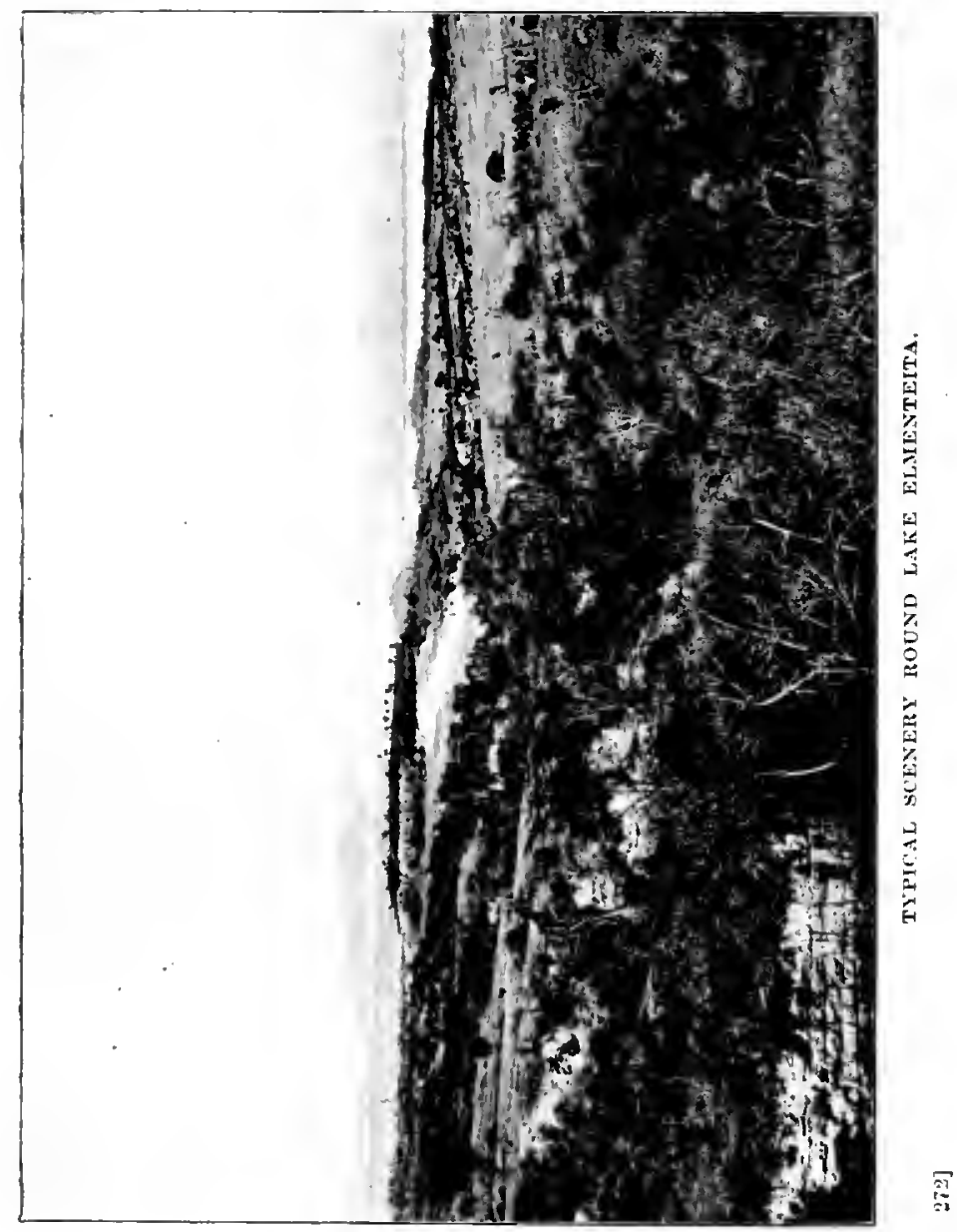



bearing upon their spiritual belief. Religion and worship do not enter into their daily life, though, periodically, semi-religious ceremonies are held: these, however, are few and far between, and are not for the purpose of worship as we understand it, but rather with the idea of invoking favours from the great spirit, such as the granting of rain. Amongst their customs and superstitions may be mentioned the non-burial of the dead, who are placed outside the "mnyatas" for hyænas and jackals to prey upon, the only exception being important chiefs, who are buried, and whose skulls are afterwards disinterred and kept as charms by their sons or successors; the chewing of acacia bark by warriors on the warpath, which produces frenzy, or occasionally complete apathy; the belief that souls of great chiefs return to their kraals in the shape of snakes; the significance of grass and green leaves, both as emblems of peace and in magicmaking by the "laibons"; and of spitting as a form of greeting or compliment. Many, however, of the old tribal customs are dying out before the advance of civilization.

The main body of the tribe has been recently removed, with their own consent, from the Rift Valley and Naivasha country, to a reserve in Laikipia, where they appear to have settled down satisfactorily. One advantage 
of this removal from civilization and the Uganda Railway is that it may lessen the ravages of venereal disease and the wholesale prostitution of the woman, and thus restore to this fine race some measure of its former virility and vitality.

Taken all in all, the Masai are a fine, open, truthful, honest, and plucky race. They have furnished the British administration with armed assistance in almost every campaign of note in British East Africa, and it seems a grievous pity that a people once so powerful should be rapidly falling into decay, the victims of an advancing civilization and their own anachronistic social system. Duty and gratitude should equally impel the British administration to take (as indeed it is doing) all possible measures for the preservation as a race of a people, once all-conquering, by whose friendship and actual co-operation many of the military operations and peaceful settlements in our youngest protectorate have been aided and facilitated. 


\section{CHAPTER XXII}

OTHER AFRICAN RACES

I IMAGine that East Africa contains representatives of almost every race on the face of the globe. I can't myself recollect meeting any Finns, Laplanders, or Eskimo there, but no doubt even these will arrive in the course of time. It is, however, only on the indigenous races that I propose to touch.

The coast-belt is inhabited by the Swahili, a cross between the original Bantu inhabitants and their Arab conquerors. Their language is a mixture of the tongues of both races, and is written in the Arab character. It is the lingua franca of Africa, and will carry you all over West, East, and Central Africa; in fact, I imagine there are very few places in Africa, outside of parts of South Africa, where one will not be able to carry on in it, and it will also serve one in Aden, parts of Arabia, and up the Persian Gulf.

The other principal races are the Wakamba, the Wakikuyu, the Rendili, the Suk and Turkana, the Wa Teita, the Galla, the Masai, 
the Nandi and Lumbwa, and the Wa Kavirondo-of whom there are two distinct races. Across Lake Victoria one meets the Baganda, the Bunyoro, the Busoga, the Buhima, and the various Nilotic tribes. Of many of these I must regretfully admit that my ignorance is profound. However, the intcrested student cannot do better than consult the numerous works extant on these, notably Sir Harry Johnston's "Uganda Protectorate" and the writings of Hollis, Merker, Hobley, etc.

The most interesting race of British East Africa are, in my opinion, most indubitably the Masai, with whom I have already dealt somewhat fully. In the meanwhile, I propose to touch lightly on some of the more important tribes of British East Africa as distinct from Uganda. The majority of the races are of more or less pure Bantu descent, mingled to a greater or less degree with the Hamitic and Nilatic stock with which they have come in contact. Having said so much we have practically condensed all that is yet known on the subject, though it is now under the close study of a number of able anthropologists.

The Wakikuyu arc a Bantu race who have spread from their original home, north and north-west of Mount Kenia, to their present location. They are an entirely agricultural and non-pastoral people, whose forest country 
is wonderfully fertile. They are by no means a warlike race, and only the denseness of their forest homes saved them from extermination at the hands of the plain-dwelling Masai. They have to a certain extent intermarried with the Masai inasmuch as the southern Kikuyu havé at various times become possessed of, either by capture or purchase, a certain number of Masai women. They have also assimilated certain habits and customs of the Masai, such as the stretching of the earlobes and their circumcisional methods. Like every African race and tribe they have a code of laws which is administered by the elders of the tribe. They have a reputation for treachery and cowardice. They are, as Africans go, fairly moral, very prolific, and under certain conditions make excellent labourers and porters. They are pagans.

The Wakamba, their neighbours, are an agricultural people, but at the same time possess considerable herds of cattle. They are a much more warlike race than the Wakikuyu, and before British occupation were always in a state of war with all the surrounding tribes. They have a curious custom or habit of migrating in small parties and setting up colonies in the territories of other tribes. Small isolated settlements of Wakamba occur in many places in British and German East 
Africa. From their habit of filing their teeth has arisen the idea that in the past they practised cannibalism, but no corroborative evidence of this has been discovered. They are pagans; their moral standard is by no means high; they believe in witcheraft and the evil eye. Up to a comparatively short time ago a secret society existed amongst them, by name "kingoli," whose members' mission in life was to discover witches. A squint or even barrenness was sufficient to convict of witcheraft, and the witch was almost invariably killed.

The Suk, Turkania, Nandi, Lumbwa, Beret, Sotik, Kamasia, together with several other smaller and less important races, are all allied to each other and to the Masai, and are probably kindred to the Bari, the Latuka, and other Nilotic tribes. Hollis in his book on the Nandi writes as follows:

"The Nandi tribe inhabited, until 1905, the whole of the highlands known as the Nandi plateau. This country was roughly bounded by the 'Uasin Gishu plateau, extending to Mount Elgon on the north, by the Nyando Valley on the south, by the Elgeyo escarpment on the east, and by Kavirondo on the west. Recently, as a result of a punitive expedition, rendered nccessary by the continued attacks of the warriors of certain sections of the Nandi on the Uganda Railway 
and on inoffensive natives, the whole tribe has been placed in a reserve somewhat to the north of the escarpment which bears their name, and away from the immediate neighbourhood of the railway.

"The origin of the Nandi people is uncertain. We know that they are allied to the Masai and Turkhana, etc., and that all of these tribes are also allied to the Bari, Latuka, and other peoples living on the Nile; but the Nandi represent doubtless a mixture of many different negro races, and, according to Dr. Shrubsall, they exhibit in their cranial characteristics the incomplete fusion of something like four stocks-the Nile negro, the Masai, the Bantu, and some pigmy element, possibly allied to the Bushman of South Africa. There may even be, he thinks, a dash of a fifth element-the Galla. In appearance the Nandi sometimes resemble the Masai, i.e. there are men of tall stature, with features almost Caucasian; at other times dwarfish types are notieeable, with marked prognathism and low foreheads. The Nandi are closely allied to the Lumbwa, the Buret, and the Sotik on the south; to the Kamasia, the Elgeyo, the Mutei and other smaller and less known tribes on the east and north-east; to the Nyangori on the west; and to various tribes inhabiting Mount Elgon, notably the Kony, on the north-rvest. The tribe of hunters usually known as the Dorobo, Andorobo, or Wandorobo, who live in forests stretching from about $1^{\circ}$ north to $5^{\circ}$ south of the Equator, are also nearly akin to the Nandi, and generally speak a dialect closely related to the Nandi tongue. The ancestors of the main body of what constitutes the 
so-called Nandi-Lumbwa group came, beyond doubt, from the north. There is a distinct tradition to this effect, and it seems probable that the tribes allied to the Nandi who live on or near Mount Elgon are only a section of the migrants, the remainder having pushed on to the south and east, and settled in Nandi, Lumbwa, Buret, Sotik, Elgeyo, and Kamasia.

"Both Sir H. Johnston and Mr. Hobley date this migration at a fairly remote period owing to the large area over which the group has spread; and I am inclined to agree with them. But I do not consider it at all certain that the Nandi country has been inhabited by the Nandi tribc for more than a few generations, for there exist in Nandi the remains of irrigation canals, which, although of no great age, are the work of other people. The Nandi have a tradition that they were at one time expelled from their country by the Sirikwa, a tribe about whom very little is known beyond the fact that they inhabited the 'Uasin Gishu plateau, that they lived in stone kraals, the ruins of which are still to be seen, and that they were eventually exterminated or driven south by the Masai. It is possible that the canals were cut by the Sirikwa; but it is more likely that the work must be ascribed to a former Bantu occupation, which in that case would not be of very ancient date.

"The more recent history of Nandi dates back less than twenty years. The country was practically closed to Arab and Swahili traders, for the Nandi, who were hardy mountaineers and skilful fighters, refused to allow strangers to cross the threshold of their 
country without special permission. It frequently occurred that caravans, after safely crossing the plains that were infested with the dreaded Masai, met with a serious check at the hands of the Nandi. On arriving at the frontier the coast people were usually met by a few old men, who told them in the course of conversation that there was a large supply of ivory at a place situated two or three days' journey from the camp, but that only a small party, consisting of ten or twenty men, might go to barter for it. So great was the avidity of the Swahili trader that he often fell into the trap, and a small party would be dispatched, laden with cloth, wire, and other trade goods, only to be ambushed by the Nandi and massacred.

"The first actual outbreaks of the Nandi were provoked by the aggressions of a Scotch trader who had penetrated into their country. The reprisals which they took included the murder of another white trader, and it was subsequently found necessary to dispatch an expedition against them in 1895. Since then punitive measures have been undertaken against them on two occasions, in 1900 and 1903, but the Nandi were never really subdued, and remained hostile to the Administration and overbearing towards other tribes. Eventually, owing to their truculent behaviour, it was considered necessary in 1905 to deal them a crushing blow, the result of which has been to move them into a reserve and, it is hoped, to settle once and for all a difficult native problem which has long confronted the peaceful administration and settlement of the East Africa Protectorate." 
Sir Harry Johnston believes that the MasaiNandi group represents an early mixture between the Nilotic Negro and the Hamite (Galla Somali). This blend of peoples must have been isolated somewhere in the high mountains or plateaux which lie between the Nile and the Karamoja country, where their kindred race, the Latuka, dwell to-day. In their southward migration they left traces of their passage on various races en route. All these races are warlike and make good fighting men, and in their own countries each was in the past more or less invincible. On the open plains the Masai were all-conquering; in their wooded hills the Nandi were the terrors of the surrounding tribes.

The Nandi are both pastoral and agricultural. They are plucky, and should make good soldiers, but are not sufficiently enamoured of work to make good labourers. They are cheery, and, like many Africans, have a distinct sense of humour of their own. In the old days their chief victims, whom they raided constantly, were the Kavirondo, whose plains run to the foot of the precipitous Nandi escarpment. Thesc Kavirondo are in reality two, or possibly, if judged by the dialects in use amongst them, three distinct races, Bantu, Nilotic, and the Congo Pigmy type. They are an agricultural, unwarlike, plain- and waterside- 
dwelling race, who, freed from the raids of their more warlike neighbours under British rule, are increasing rapidly, and make the best labourers in the whole of British East Africa. They are one of the few races whose men and women go about entirely naked. They have the reputation, which $I$ personally believe to be entirely erroneous, of being an exceedingly moral race. They live in villages usually walled or hedged, and are very unclean in their personal habits.

Such, in an extremely " tabloid" form, is an outline of some of the principal races of British East Africa. For the anthropologist and student there are books, pamphlets, and periodicals without number wherein can be studied the ethnology of the country. Possibly the minute synopsis which $I$ have given will prove enough or more than enough for the general reader. 


\section{CHAPTER XXIII}

\section{REMINISCENCES}

As I look back on the years spent in Equatoria many memories and reminiscences come crowding back. To the untravelled "travellers' tales" must always be taken with the proverbial grain of salt. Any man or woman whose existence has been spent amidst the ordered life of cities is of necessity unable to realize entirely a state of living in which there is no law, no civilization, no society, no streets, offices, houses, institutions, nothing, in fact, save the open countryside and the will of the strong man. It is by no means their fault. Imagination has its limits, and a state of existence such as I have indicated is as much outside the limits of a stay-at-home imagination, as is an adequate conception of a future life.

The typical attitude is somewhat that of a dear old lady to whom I was relating some experiences of mine undergone in an out-ofthe-way corner of the globe, with my nearest white neighbour some couple of hundred miles 
distant. She listened with apparently the deepest interest, and I flattered myself that she was taking it all in. Suddenly she turned to me and said, "There is one thing, Captain Wilson, that I don't quite understand. Would you mind explaining to me?"

" Certainly," said I.

"Tell me," she said, "how did you arrange about going to church on Sundays ?"

An existence without Sunday church simply was an impossibility, not even to be remotely imagined, to the dear old soul.

It is with somewhat the same feeling that the old lady inspired me that one puts forward stories of queer happenings in strange places. One's hearers don't really mean to call one a liar, but they aren't physically able to believe what they hear. And yet, like the story of the old lady and Pharaoh's chariot wheel, they will swallow the most amazing anecdotes without turning a hair. .For instance, if I didn't happen to know that it was true, I should frankly disbelieve the story of the man who killed a rhinoceros with a pocketrevolver. Rhinoceros aren't killed with pocketrevolvers any more than mad dogs are slain with toothpicks or pickle-forks. But the stayat-home individual knows that rhinoceros are animals which are shot, and that revolvers are machines for shooting: hence their rela- 
tion is obvious, and the story inherently probable.

All this by way of leading up to some tall stories, which, however true they are, I neither ask nor expect any of my readers to believe.

I may as well commence with two lion stories, which, as they have been told by Colonel Patterson in his admirable book "The Man-Eaters of Tsavo," may stand a better chance of being believed. In the early days of the Uganda Railway, a state of panic was caused in the large coolie camps, whose occupants were engaged in the construction of the bridge over the Tsavo River, by the ravages of a number of man-eating lions. What was the total number of their victims I have forgotten, but I know that it was considerable. On one occasion a small Indian boy was walking at dusk along the permanent way towards camp. Suddenly he heard a rustling in the bush, and was terrified by the appearance at a short distance from him of a lion. Flight was useless. There were no trees to climb, but on the edge of the permanent way was standing a zinc tank with a small circular hole in its top. With considerable presence of mind he made for the tank, which was empty, and succeeded in squeezing his small body through the aperture and getting inside. The lion followed up, and, getting on top of 
the tank, inserted a paw through the opening. The boy was crouching at the bottom of the tank, and the paw just reached him. He had a box of matches with him, and with these he burnt the beast's paw every time it was inserted. In the course of time the matches were exhausted, but the lion continued his efforts. When morning came the tank was found, bruised and battered, with the boy still inside and comparatively unharmed by the lion, but insane from the terrors of the night. The tank had been turned over and over by the lion, and moved some considerable distance from the place where the boy had got into it. The boy eventually recovered, but what his feelings during that night must have been can hardly be imagined.

Three Europeans from Nairobi determined to attempt the extermination of a celebrated man-eating lion which was creating a reign of terror near a station on the railway. To this end they left Nairobi by train, and, on arrival at their destination, had their carriage cut off and run into a siding. The lion was in the habit of taking in the station in his nightly round, so they determined to remain in their carriage and trust to getting a sight of him from the windows. After dinner they stayed watching for some time, and as the lion did not show up, they decided that two of them 
would turn in and that they should take turns in watching. The first watcher was a police officer. The carriage was the ordinary Indian pattern, in which a sliding door at one end gives entrance to the carriage. Inside, two seats or bunks ran lengthways along the carriage, one at the ordinary height of a carriage seat from the ground, and the other on the opposite side some five feet up, over a table which ran along. the side of the carriage. The watcher took the lower bunk, one of his companions the upper, and the third man lay down on the floor.

Whether it was that the siding was bad (it was in early construction days on the railway), and that one side had sunk, so that the door could slide open, or whether it was that the door had inadvertently been left slightly open, will never be known. It must be, however, that the watcher had fallen asleep, for the man on the top bunk was suddenly awakened, and saw to his horror that a lion had entered the carriage (the door being now wide open), and was standing on the body of the man who had been sleeping on the floor. Imagine his sensations! The rifles were in a. corner of the carriage out of reach of all three men. Suddenly the lion seized the watcher, dragged him from the bunk, and with the body in his mouth left the carriage by way of 


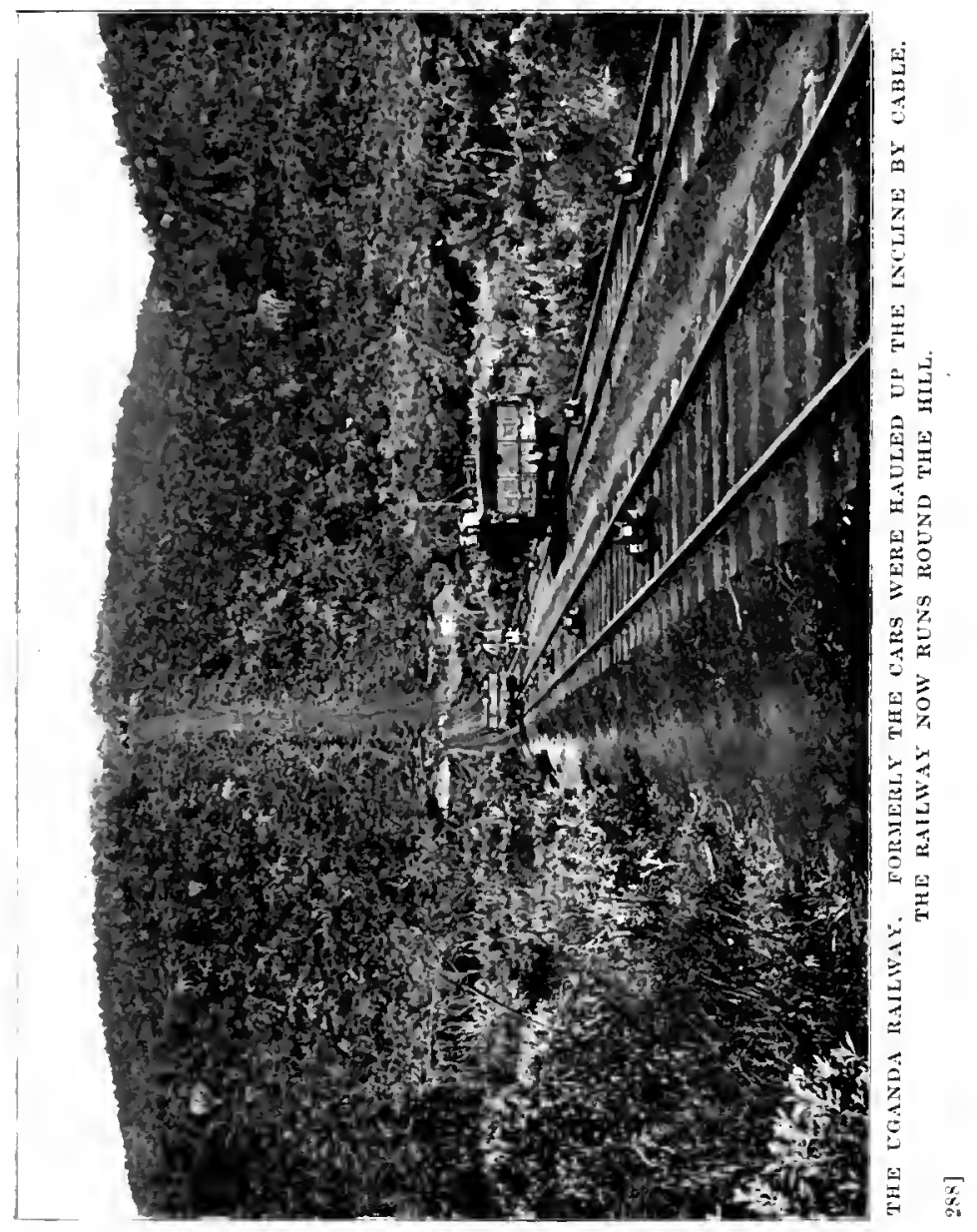



the window over the bunk, carrying away glass and woodwork in his passage. When he was shot shortly afterwards one-if not both-of his eyes were found to have been gouged out by his victim. This story I have heard repeatedly from both the other occupants of the carriage on the fatal night.

A trader and his wife were sharing the same tent in the vicinity of Mount Kilimanjaro. During the night a lion entered the tent, and the wife saw her husband dragged screaming from his bed, and heard during the rest of the night the man-eater making his meal some few yards from the tent. A further horror is introduced into some versions of the story (for which I do not vouch), to the effect that after the conclusion of his feast the bloodcovered animal once more entered the tent, passed through it, and drank from the bath in rear.

It is hard to find humour in stories such as this, but the following telegram-one of many such preserved in the offices of the Uganda Railway-verges on the comic. The sender was the Babu station-master at Simba (Lion) Station :

"A lion is troubling too much. Since three nights lying on verandah and trying to get into station room. Please send proper car- 
tridges for Snider rifle first train for protection. Blank cartridges are of no use at all."

Another wire from an Indian telegraphist (let us hope apocryphal) is reputed to run as follows :

"Lion on platform devouring station-master. Have barricaded self in office. Please arrange. Down goods shortly due. Matter urgent."

While on the subject of babus the following story deserves a place.

At an out-of-the-way station in India the only officials were the station-master and telegraphist. One morning the Traffic Manager of the line received a wire from the latter:

"Station-master dead at six a.m. Please instruct."

The reply was sent:

"Make sure station-master really dead, then bury him."

One can imagine the T.M.'s feelings on recciving the following:

"Have made sure station-mastcr is dead by striking thrice on head with fish-plate. Am now burying."

However, to hark back to animal stories, let me deliver myself of the following. In a 
certain district in East Africa rain is-to employ journalese-conspicuous by its absence. There is in these parts a large depression across which runs a much-used native track. The depression resembles the bed of a large, shallow, dried-up lake, and is several miles in extent. During British occupation-some twenty years-the depression had always been dry. At last, however, heavy rains arrived, and two Europeans travelling arrived at the dried-up lake-bed and found it in a swampy condition from the quantity of rain that had fallen. They determined to camp there for the night, and while camp was being pitched, they strolled down to see if the swamp could be crossed, or whether a detour would be needful. On arrival at the edge of the swamp they noticed sluggish movements and heavings in the mud, and to their amazement found the basin full of thousands of semi-torpid crocodiles emerging lethargically from the mud which had imprisoned them for so many years. They shot and shot and shot-walking up to each torpid beast in turn and doing the business with one bullet-till their ammunition, some three hundred rounds, was exhausted, and then they moved camp, having made no appreciable diminution in the numbers of the vermin.

Of course big game shooting exacts its toll 
of deaths from its devotees, and even more numerous than the deaths are the number of "close calls" that occur. One of the nearest things that I can remember hearing was the case of a man who, following up a wounded bull elephant along an elephant track hedged on both sides by twelve-foot grass, came face to face with the beast on rounding a bend. The elephant charged, the man (most unwisely) turned and ran. This, needless to say, is the worst possiblc course. The elephant is bound to catch you-he goes twenty times as fast as you do. The only thing to do is to stand and shoot, and, if you don't stop him, let him get as near as safely possible, and then dive into the thick stuff to one side, and it's a million to one that he will over-run you and give you time to reload or get away before he comes back-if he does come back.

However, our friend chose the worse part and ran. He had gone a few yards when he tripped, fell on his head, and stunned himself. When he came to he found himself lying on the ground between the elephant's fore-legs. The beast was kneeling and was digging about with its tusks and trunk at the path in front of him. It had evidently tried to kneel on him-a favourite proceeding - and had missed. He realized that the sooner he got out the better, so he did a backward wriggle and 
crawled out, passing between the animal's hindlegs en route. When he got clear he went a few yards down the path and proceeded to faint. When he came to again he found the elephant lying dead in the same place where it had knelt-and, as an elephant's weight runs to something in tons, he realized that he had had not only one, but two remarkably fortunate escapes.

Another friend of mine had the most thrilling ten minutes of his life with a wounded elephant, which shikarred him for that space of time round and round a forty-or fifty-foot baobab tree. When the pachyderm eventually gave up the contest, he left behind him about the most relieved man in Africa.

One of the greatest trials that can happen to one in a tropical country is thirst. It beats hunger all ends up. I speak from experience of both. One can go without food for a comparatively long time without any serious inconvenience, but thirty odd hours without a drink - the longest I've ever been -is not a thing to forget, especially in the tropics. I've been hung up for water several times, and $I$ think that the drink $I$ enjoyed the most of any I've had in my life was one of thick, green, slimy water which I found in the deep impress left by an elephant's foot in what had once been swampy ground. 
A nasty experience was to arrive hot, sweating, and parched with thirst at the only water-hole in the district-nearer than the river which I had left seven hours before-to throw myself flat on the brink and push my head over to drink-and to find myself looking into a pale-green face, belonging to a nigger who must have fallen in and drowned himself -exhausted with thirst-at least (to judge by his condition) a week previously. We had to drink the water though-or go without any, but we boiled it pretty thoroughly first.

Before quitting a chapter of "reminiscences" I should like to retail a couple of stories of that cheerless spot, the Nile Valley.

At the time of which I write, the River Nile was the boundary between Uganda and the Congo Free State. In the river were some islands inhabited by a few people, the ownership of which was in dispute. It happened that in one of the periodical émeutes of the Congo Free State troops, a party of their soldiers (cannibals all) canoed over to the islands and had several hearty meals resulting in the disappearance of the inhabitants. M. le Commandant on the Belgian bank was deeply distressed when he heard of these happenings, and wrote to Colonel $\mathbf{X}$., commanding on the British side. The letter was tactful in 
the extreme. M. le Commandant expressed his profoundest regret that such an incident could have occurred-was desolated and in despair, but, the incident having actually happened, life could not be rebestowed to the viands, and rather than cause pain and unpleasantness in Europe over a slight mischance such as this, could not the incident be allowed to slip quietly into oblivion? In a word, could M. le Colonel $\mathbf{X}$. see his way to making no report as to the lamented occurrence? Colonel $\mathbf{X}$. replied that he entirely appreciated M. le Commandant's feelings in the matter, and that he quite understood his motives, but that he feared that duty compelled him to make the report in question. "But," he added, "I will, of course, insert a special paragraph stating that $I$ have pleasure in submitting M. le Commandant's own assurance that he himself took no part in the festivities." Possibly, in order fully to appreciate the point of the story, a visit to the Congo Free State, as it was in those days, is necessary.

It was $I$ think the same Colonel $\mathbf{X}$. who was first given command and civil charge of the Nile District. Previous to his arrival, there had been a few isolated posts each under its own officer. One of these posts was under the command of an officer whose zeal for work was hardly the dominant feature of his 
character. Finding the shooting considerably better on the Belgian bank of the river, he took up his residence there at a spot some ten miles or so farther down stream than the post where his company resided. His native officer commanded the post, and used periodically to visit him and report progress, and he, if he was feeling full of energy, might visit his commando once a month or so. (Mind, this was many, many years ago: such things don't happen now.) Upon him descended one evil day that zealous soldier Colonel $\mathbf{X}$., and found him not at home. A message was despatched requesting his presence, and informing him that the newly created O.C. Nile District would inspect his, Lieutenant Y.'s, company at seven a.m. the following morning.

Seven a.m. saw the company and Colonel $X$. on the parade ground, but no Lieutenant $Y$. At 7.30 a canoe was observed coming up stream, and at 7.45 Lieutenant $Y$., in a uniform of sorts, stepped ashore, saluted, and proceeded to apologize for his absence. "We will go into that later," remarked the Colonel. "Now that you are here I should like to see your company go through the Manual Exercise." With the most seraphic of smiles Lieutenant Y. replied: "Yes, sir. So should I, sir." 
To this day Y. laments the shortness of his stay in Africa, and asserts somewhat sadly that " though Colonel $\mathrm{X}$. is a top-hole soldier, I don't somehow think that he has a strong sense of humour." 


\section{CHAPTER XXIV}

\section{RELIGIONS AND MISSIONS}

BEFore commencing this chapter let me confess to very considerable diffidence as to treating its subject-matter. A discussion upon religious subjects almost invariably arouses bitterness, and further, strictly speaking, it is outside the scope of the present volume. However, as it is impossible to spend five years in a country without learning something of its faiths and creeds, and as, as was once said to me, it is equally impossible to spend five minutes in Uganda without meeting a missionary, I think that I may be allowed to touch upon these subjects.

Primarily all Equatoria was frankly pagan. Even idol-worshippers were the exception. Most races and tribes had-and still havesome idea of a Supreme Being, to whom in moments of need they are wont to address supplications for assistance. The priestly class had practically no existence-unless witchdoctors could be so designated-which in my opinion they could not properly be. 


\section{RELIGIOUS FACTIONS IN UGANDA 299}

The first great religion which touched the country was Islam, brought by the Arab conquerors of the coast-lands, for $I$ do not think that the Christianity of Vasco da Gama's followers, or of the successive white men who encroached upon the coast, made any durable impression. In due course of time, however, Christian missionaries appeared on the coast, and after the late Sir H. M. Stanley's appeal, they penetrated in considerable numbers into the kingdom of Uganda. In time the various creeds in Uganda, Protestant, Roman Catholic, and Mahomedan, became frankly synonymous with three political parties. Wars were waged between the three faiths, and religion, as religion, was about the last thing that any one, with the exception of a few devout men, troubled their heads about. Upon the taking over of Uganda by the British Government the political aspirations of the three "religious parties" and their constant bickerings and intrigues went far to unsettle the country, and were the greatest stumbling-blocks to successive administrators. Fortunately that regime has passed away almost in its entirety, but it has left behind it many evil traditions and the seeds of many difficulties.

At the time when I left Equatoria the faith which was gathering in a hundred converts for every one drawn to the combined fold of 
all other faiths was Islam. My own opinion is that in the course of time all Africa will be Mussalman. Religion is, according to a theory of mine, which I do not propose to expound at length, to a very great extent a matter of geography. Certain countries and certain climates do, as a matter of demonstrable proof, produce in their inhabitants, and to a less degree in temporary sojourners, certain definite and pronounced mental and physical attributes. "East is East and West is West, and never the twain shall meet," and the very last possible meeting-ground is the ground of creed. An Eastern religion is as suited to the Oriental as it is unsuited to the Occidental, and vice versa. Therefore, since paganism is bound in due course of time to disappear, it is permissible to speculate upon which of the great religions of the world is both suitable and likely to take over its abandoned habitations. The answer to both questions is, I think, the same. Islam is in my opinion the faith most likely and most suitable to succeed paganism, and I shall try to put forward the reasons which have formed my conviction.

In the first place I conceive that most reasonable men and women believe in these days that a good pagan, a good Mussalman, or a good Buddhist, is a better man than a bad 
Christian. Personally, I go myself a step farther than this, and believe that a good man of any faith is on an equal plane of goodness with a good man of any other faith, be their creeds what they may; in short, that a good man living or striving to live honestly up to his convictions and beliefs-whatever they may be-is a good man, whatever be his race, creed, or colour.

I speak in this connection from an entirely abstract and ethical point of view. It would, of course, be folly to assert that a good, say, Zulu is an equally useful member of society as a good Christian, but from the abstract point of view it seems to me that if each of them devotes his life to "acquiring merit," as the Buddhists say, if they each play the game according to their lights, if they each do their best-and no man can do better-they stand an equal chance of reward in their respective paradises. All creeds are not equal, and one can no more compare practically our two types than one can compare the head of the sixth form with the head of the first. Theoretically both are equal, since one's best is one's best. Therefore, since the adoption of a creed is almost entirely an accident of birth and environment, surely he who follows unswervingly the tenets of his own creed and conscience, and whose life is an influence for 
good, is, as a question of abstract ethics, on the highest moral plane?

This, however, is possibly somewhat beside the point which I would make, being merely my own personal view. My point is that in the eyes of the majority of liberal-minded men, a bad Christian is a worse man than a good man of another faith.

Secondly, I hold that every religion is in essence one and the same, and that one can safely disregard the multifarious man-made dogmas with which every creed has become overlaid and encumbered. It would perhaps be more accurate to say rather that every creed is a branch of one universal, instinctive, and inherited religion, which is inherent in the soul of every man and woman at the moment when that soul is born into the world.

These two points are in the main, I imagine, accepted as axiomatic by every intelligent individual who is not blinded by the bigotry of his own especial creed.

To any person who has studied both Islam and Christianity it is needless to point out the fundamental similarity of the two creeds, but there are very many-the majority of Christians and Moslems in fact-who have not done so. Since Islam, the newer faith, was built up by the Meccan epileptic upon a foundation derived from the primitive Chris- 
tian anchorites of Arabia, from the traditions of the numerous Jews of the Hijaz, from the Syrian, Greek, and Abyssinian Churches with which he was in touch, it follows that the resemblance must be striking. As abstract faiths they are practically one and the same, differing only in what are virtually points of dogma-important if you will, but dogma nevertheless. Mahomed's early preaching was largely an exposition of the messages of the Old Testament prophets, and was in the main, as was early Christianity, a monotheistic protest against the polytheism of idolatry.

In a comparison of the two faiths, Islam stands out as being the morc rude and physical, the more uncivilized and primitive. It is, in a word, what Christianity was some centuries ago, the faith of the religious zealot, burning with ardour but lacking in perspective. It is the narrower, the stcrner, the simpler, and the more rigorous crced, the creed of the ascetic and the fanatic, while Christianity appeals rather to the morc highly developed intelligence.

A considcrable number of years spent in the study of Islam, both in Asia and Africa, have convinced me that, if the pagan has to be weaned from his paganism, Islam is by far the best fold into which he can be gathered, 
at any rate in the first instance. In addition to its being the ideal faith for the, as yet, mentally undeveloped races on account of its comparative simplicity, its stubbornness, and its virility, it has in its favour the all-important fact that between the covers of the Koran lies the Moslem's entire temporal as well as spiritual code.

The Koran is, in fact, the latest edition of the laws of Moses, upon which indecd it is founded. It contains all that is necessary for its student to know-religion, law, medical and social institutions. The convert to the Moslem faith is not confronted at the outset by bewildering and apparently contradictory differences between the law of God and the law of man, within and without his book of faith, which differences so often prove a stumbling-block to the Christian proselyte. The latter requires, in addition to his Bible, a course of instruction in social and political economy - to say nothing of logic-in order to reconcile the apparent variations between fact and theory which he daily encounters.

In a word, it requires an educated man to appreciate Christianity as it is now taught. The Christianity of to-day is an infinitely more subtle and complex faith than the creed which was preached by the carpenter's son in Palestine. Had the twentieth-century interpreta- 


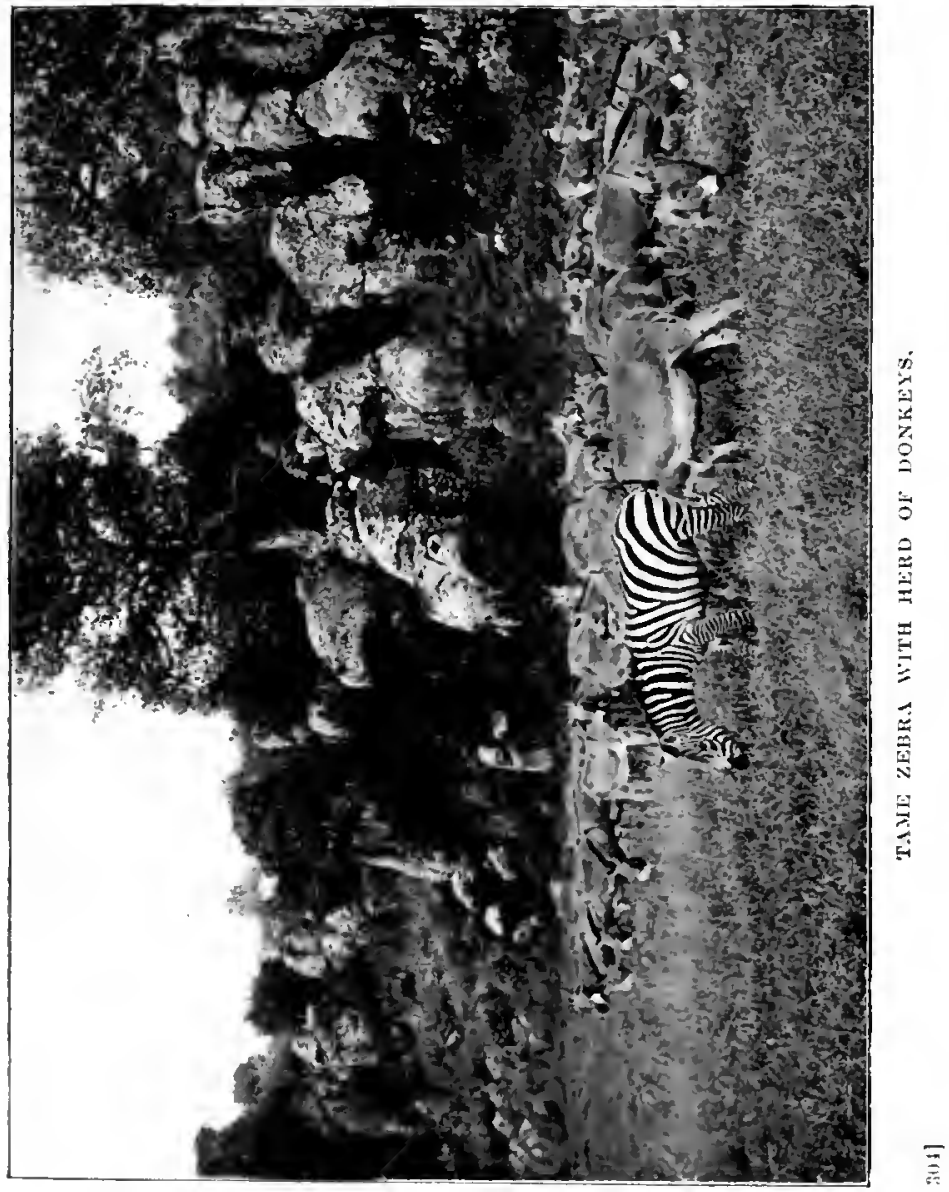



tion of the Christian religion been the gospel preached by Christ and His disciples, it is a matter for speculation as to how many converts would have been obtained. Religions, like all other things of this world, are subject to evolution, and as education has advanced so has the religion of the educated peoples, and to-day Christianity is the faith of the educated and developed nations.

The uncivilized pagan, not being possessed of a logical, reasoning brain, requires one of two things. He must have either a clear and simple code, which his undeveloped intelligence can grasp in its entirety, or he must have some one individual, upon whom he can pin a blindly trusting faith, to explain in a manner that he understands those matters which are beyond his comprehension. The child in his nursery, absorbing the first elements of Christianity, has that limitless faith in his parents that enables their explanations to overcome any seeming inconsistencies which puzzle his small brain. In parenthesis, that same brain, when man's estate is reached, has to do some hard thinking to evolve its owner's attitude towards religion and belief. Further, the child has no knowledge of the world's daily life. The savage, however, whose mind is in many ways the mind of a child, has a very present knowledge of his workaday world, 
and the missionary, try as he may, is but a poor substitute for infinite comprehension.

Of all branches of Christianity, the Church of Rome (incidentally, but aptly enough for my argument, the most retrograde section and the most opposed to education) is the most attractive to the blind believer, to him of unquestioning faith. And so, since simple faith is more demanded by the Roman Catholic Church, since she, though to a less degree than Islam, stands for simplicity, so far as the individual is concerned, it follows that her missions are the most successful of any Christian missions. The Protestantism of to-day, complex in its entirety, leaves much more to the individual intelligence, and consequently appeals more generally to the thinker and to the highly educated, and the more complex the sect of Protestantism, the more highly educated its adherents. Neither religion, however, can approach the creed of Mahomed in ministering to the needs of, or appealing to the instincts of, uncivilized humanity.

Go to any European official, settler, trader, business or professional man in Asia or Africa, and ask him who in his opinion are the best and most reliable natives, and who the worst. The answer is invariably the same. The best native is the Mussalman, the worst the " mission boy." This is not blind, unreasoning 
prejudice. It is solid, substantial fact, the result of observation and experience. Deplorable it may be, but it is none the less true, and it goes to prove that Christianity is not the rcligion for the uncivilized or semi-civilized man. I do not mean to assert that Christianity has of necessity an invariably debasing influence upon the coloured convert, though such an inference might, in a large number of cases, very fairly be drawn.

The fact is that the genuine, believing, voluntary convert is the rarest of rare birds. The average native Christian is a low-down outcast, who is ready and willing to profess anything which promises the likelihood of a soft job. To this class of individual the local mission presents an ideal field of operations. His designs are greatly facilitated by the vicious spirit of competition, which is unfortunately so prevalent in missionary circles abroad. The spirit of rivalry, of reckoning success by a count of heads, by the number of converts obtained, must of necessity be fatal to any real missionary work. Yet such a spirit is only too common amongst missionaries of almost every denomination.

I do not desire to convey by my words the impression of an attack upon missionaries in general. I have met many, and have admired and respected, and do admire and respect 
some of those whom I have met. But not all. There are many types; it will suffice to enumerate three. There is the sincere, devoted, self-sacrificing minister of the Gospel: sometimes bigoted; sometimes fanatical; sometimes obstinate and difficult; but invariably a man to respect and admire. There is the disillusioned missionary : and the man who has lost his ideals is always an object for pity. And lastly there is the missionary who is a missionary because he can get a living more easily that way than in any other. Further than this I do not propose to touch upon this branch of my subject.

I wish, however, to enter a protest against what appears to me to be the fatal flaw in the whole system. Briefly stated, it is this: What the savage needs is not religion, but education. He has at his elbow a creed which I have tried to show is infinitely more suited to his requirements than Christianity. What he requires are missions entirely secular and industrial. Do not let us force upon him, what must at present be an empty form of superstition, but rather let us pave the way for religion by preparing his mind for the reception of higher truths. Teach him to think and to reason, and thought and reason themselves will turn his mind to religion. The yearly toll of lives sacrificed, of money 
spent-say rather wasted-in foreign missionary enterprise is matter of the deepest regret. Let the priests of Christianity devote themselves to good works and conversion amongst the poor and needy in the teeming slums and courts of our great cities, whose need is so infinitely more pressing and pitiful than that of the negro or the Asiatic. Let the vast sums, now devoted to the hopeless-and needless-struggle with another and more suitable faith for the souls of the coloured races, be spent in sending forth the lay teacher and the doctor in place of the priest, and let the mission station become a place where tuition, education, and instruction can be obtained by all comers, without the embracing of an alien creed as a sine qua non. Let there be priests also to minister to the spiritual wants of the occasional genuine convert, and to expound the Gospels to the seeker after Christianity, but of every twenty now employed, withdraw nineteen to the vast field which our own country offers, and the supply will still exceed the demand. At present they are wasting their lives, their energies, and much money, which might be so much better employed, in the useless struggle to force upon other races a faith unsuitable and undesired.

In the present stage of development, Islam and Christianity, though they can and do 
exist side by side, can no more fuse than oil and water. When, in the centuries to come, civilization and education have permeated the Moslem world, as they must, and are, indeed, now commencing to do, a new and more tolerant Islam will arise. As I have said before, all religions are in a state of evolution, and education brings broad-mindedness with it. Islam is now what Christianity was a few centuries ago, and its adherents are in bulk on the same mental plane as were the early Christians. A few centuries hence, education will have carried Islam forward to the level of contemporary Christianity. Further ahead still, this regenerated Islam will blend with Christianity, Buddhism, and all other creeds throughout civilization into one universal world religion.

In the meanwhile the keen, heavy tool fashioned by Mahomed is a far more suitable implement for rough-hewing into shape the crude mass of paganism than is that finer instrument which we call Christianity. Primitive man is at present pagan : Christianize him, and lie ceases to exist, or drags out a debased and degraded existence, a victim to the vices, and unsaved by the virtues of Christianity. Admit him to the Moslem fold, and he, in due course, becomes a useful member of society, a man and not a debased animal. 
I take it that the world is passing stage by stage from the darkness of savagery to the ultimate light of the perfect civilization -not, be it understood, our present-day, twentieth-century civilization, but the ultimate, final stage of upward evolution, which, in parenthesis, I imagine will be simple and natural, and not artificially complex. The greatest factor in our upward progress is education. Religion is, or at all events has been, a retrograde force, which has to its discredit more wars, intrigues, death, bloodshed, torture, and miscellaneous slayings than any other cause or factor in the history of the world.

Up to comparatively recent times, religion overbore the civilizing tendencies of education. Now education has to a large extent overborne the intolerance, narrowness, and bigotry-all making for retrogression-which religions-or one should rather say Churehes-have invariably engendered. The victory of education over the retrograde passions of the Charches is not yet complete, but its completion is inevitable. The ideal state is an educated religion, but sinee education is acquired and religion instinctive and inherited, since education makes more for progress than does religion, since education brings religion (for every thinking man has a creed of his own) while 
religion does not of necessity bring education, it follows that if -we seek progress we must develop education. Amongst ourselves this development is in progress, but there arc those of us who would better other races besides ourselves. Such are the main supporters of missions. Let them become supporters of the true instrument of progress. Solomon asked -and was commended for asking-for wisdom, not for religion. Therefore let the schoolmaster take the place of the missionary in the dark places of the earth, and an important step towards the ultimate state of perfection will have been taken. 


\section{CHAPTER XXV}

THE COUNTRY

By the time that he has progressed so farshould indeed his long-suffering patience have sufficed to carry him forward-" the gentle reader" will probably ask: "But what kind of a country is East Africa? I don't seem to know much more about it now than I did when I started."

Well, I didn't sit down to write a guide-book, and all the solid, hard facts and statistics and the like, which the student loves, can be found in a dozen really valuable books on the countries of which I have tricd to discourse. As I said in the first pages, this volume is in no sense an authoritative treatise on Equatoria, but rather a random series of sketches and anecdotes. However, as I seem to have said very little that is definite concerning the countries themselves, and, moreover, as I have already departed from the realms of anecdote and reminiscence, and have touched upon subjects more serious and solid, I will bring this volume to an end by writing of subjects 
which should, I suppose, have been dealt with first rather than last.

British East Africa and Uganda-British Equatoria, that is to say-can be very roughly divided into three zones or belts. The first is the coast-belt, a fertile, tropical country, where effective European colonization is impossible for climatic reasons. This, from a commercial point of view, however, is probably the most profitable portion of the country to exploit, not only from its fertility, comparatively easy labour conditions, and climatic suitability for the production of such commodities as rubber, coco-nut products, etc., but from the comparatively easy means of transport which proximity to the sea affords.

From the coast-belt the country rises to a great tableland, running from five to ten thousand feet in altitude. On this tableland colonization is possible, and it is now extensively inhabited by white settlers. The climate is in most places excellent, resembling rather that of the South of France than that of Equatorial Africa. It used to be an ideal country to live in in the old days. Whether the influx of a considerable white population has added to or detracted from its charms I know not. Of its productive possibilities I shall speak later.

The tableland falls again to the tropical belt 
in which lie Lake Victoria and the Uganda Protectorate, which is a frankly tropical country, not suitable for colonization, with a climate which varies between bad, very bad, and damnable.

When writing of a country as fitted for colonization, I imply (as I think is generally understood) a country wherein a European is able to make his permanent home, marry, breed, and bring up children, and spend his life without the necessity of ever revisiting Europe on the grounds of health, and where his offspring can spend their entire lives. This, with certain reservations, I believe to be climatically possible in certain parts of the highlands of East Africa, and, as I have said, many settlers have already cast their lot in these highlands. What influence their presence will have upon the future of the country, what that future will be, and what will be the ultimate destiny of the settlers and their descendants, are matters not altogether easy to forecast.

Turning for a moment from speculation as to what the future may hold, I should like to try to answer the question that one is so frequently asked: "Is British East Africa a white man's country?" This question should, I think, be more properly expressed as : "Are the highlands of British East Africa a 
white man's country ?" since no other portion of British Equatoria has the slightest claim to be so considered.

Before attempting to answer the question myself, I should like to record the answers which I have received from very many men who know the country intimately. These vary very considerably, and range from the opinion that the African highlands are a finer country than Canada, to the uncompromising "No; and no part of Equatorial Africa is or ever could be a white man's country." Such different views, coming from men who know their subject thoroughly, tend to prove that the suitability of the African highlands for European colonization is by no means a demonstrated fact. My own personal opinion lies somewhere midway between the two extremes. I think that the highlands are, with certain limitations once realized, a white man's country, but these limitations must always be very clearly borne in mind.

Although the highland climate, so far as comfort and sensation go, is an ideal one, it must never be forgotten that it is to a certain extent treacherous. From the country's geographical position the sun's rays are almost vertical, and are therefore far more powerful in effect than sensation would cause one to imagine. To ignore the sun's power, though 
it may not be obvious, is to court ill health. Again, it must be remembered that life at such considerable altitudes is life in a very (comparatively speaking) rarified atmosphere, and a rarified atmosphere has undoubted effects both physical and mental upon the human body. Possibly the most obvious effects are upon the nervous system, but exact particulars are, I think, beside the point. What is to be noted is that European dwellers in the African highlands are, though they may be unconscious of the fact, subjected to certainto them-abnormal influences, due to the sun and to the altitude of their abiding-place. It is therefore essential that their mode of life should be framed to meet such abnormal conditions, and that their general health should be an object of attention. One cannot take the same liberties with one's constitution in Africa as one can in Europe, and to permit oneself from any cause to get "run down" is the almost certain precursor of sickness, more or less serious.

Africa also is a country of many and strange diseases, and of many insect carriers of disease. In addition to the sicknesses of most other countries, Africa has her own store of special and exclusive maladies-both for men and beasts. This, of course, is generalizing, but it goes to prove that the climate of Africa 
tends to the promotion of sickness rather than of health. However, since the majority of African diseases, as regards human beings at any rate, are not indigenous to the highlands, one may, I think, safely say that, provided all reasonable precautions are taken regarding one's general health, the highlands of East Africa are a white man's land.

One point, however-though it is really included in what has gone before-should not be overlooked, for it is a point of especial importance to the settler. This point is : "Don't work too hard." By this I imply manual and physical labour. A man cannot, as in more favoured climes, such as Canada, labour on his farm day in and day out without running serious risks to his health. East Africa is not a country for white labour, and the settler is far better advised who oversees and assists black labour to do the "donkey work" than he who strives to accomplish an equal amount of physical work to what he has been accustomed to perform in more temperate lands.

Many new arrivals are misled by the apparent mildness of the climate, and forthwith proceed as they have done in their former homes. Hard physical work, exposure to climatic risks, and economy, with its resultant lack of comfort in the home and of proper 
nutrition with regard to food, are the order of the day, with the almost inevitable result of a breakdown, more or less serious, as the case may be.

Very shortly after my arrival in Africa, an old and experienced resident said to me: "The secret of health in this country is to do yourself as well as you can." Subsequent experience proved how right he was. What would be luxuries in Europe are necessities in Africa. A comfortable home, good food, good clothing, absence of undue fatigue and (if possible) worry are all of them important factors in the preservation of health. The all-important problem of existence is to keep in hand a reserve of strength against possible emergencies. If you toil at something approaching breaking strain, the climate-wherever you may be in Africa-will eventually get you. If you are in the fortunate position of being able to return to Europe directly sickness strikes you, you can go ahead and work up to your full capacity in Africa. The change of climate alone will probably restore you to health and send you back to the scene of your labours with a barrier of reserve force built up against future accidents. But if, on the other hand, you have to fight your disease on the scene of its inception, you arc faced by a very different state of affairs. You may, and 
very probably will, stave off and defeat the attack, but continual renewals of the strenuous life, injudiciously practised, will in time give the ultimate victory to disease.

Therefore it would seem that the answer to the oft-propounded question, Is East Africa a white man's country?" should be "Yes, provided that the white man realizes that he is facing abnormal, though not apparent, climatic conditions, and that, bearing this in mind, he conserves his energies as far as may be, watches his health and general condition carefully, and takes every opportunity and uses every means of creating and sustaining a reserve store of health, strength, and energy to resist unforeseen and unexpected attacks of sickness." Under these conditions and rules of life, the highlands of British East Africa are not only a white man's country, but one of the most delightful countries of the world in which to reside. I know that I personally would, in certain circumstances, ask for no better lot than to pass my days on those vast uplands which I love so well. 


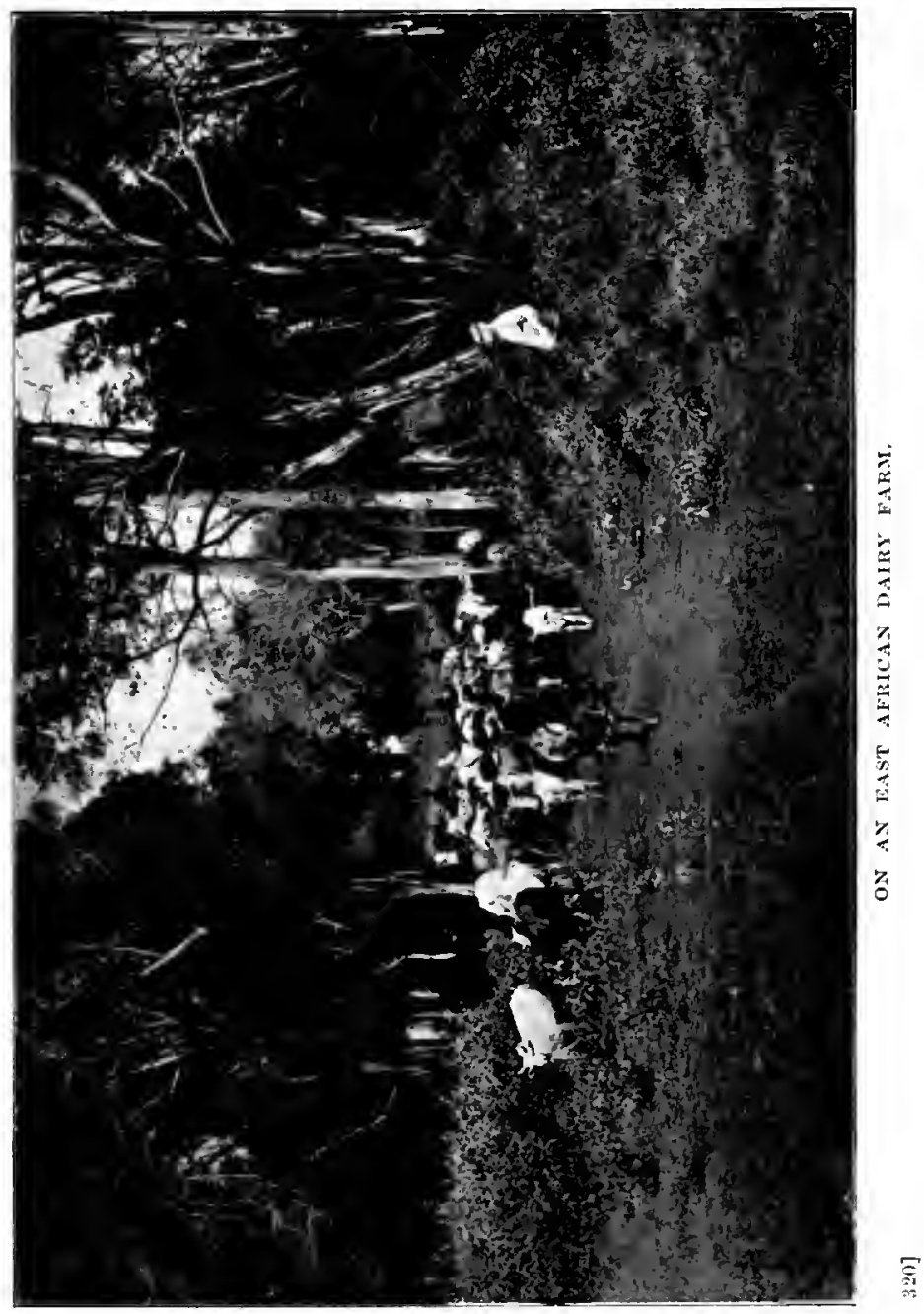





\section{CHAPTER XXVI}

THE FUTURE -

IN the preceding chapter I permitted myself a passing speculation upon the future of British Equatoria and its white inhabitants. In this chapter I propose to deal with the problem of that future, guided by opinions far more valuable than my own, by inference, by deduction, and by observation. For the purposes of commerce and trade the country divides itself into two sections-the low-lying, tropical belts, and the highland, partially colonized districts. I propose to deal with both separately, but, before so doing, to take a general survey of the commercial and financial situation as it presents itself to-day.

When I left Nairobi at the end of 1906 there was a land-boom in progress, and landvalues had in consequence risen to an altogether inflated and absurd level. Shortly afterwards the inevitable slump followed, and there was general disintegration, financial and commercial. As I write this chapter (October 
1912), I am informed that there is another boom, and that land is being bought up at prices which seem to me frankly ridiculous. I sincerely hope that no slump will follow on this occasion, but I admit that when I hear the stories of the marvellous prosperity of the country, and of small estates changing hands for thousands and tens of thousands of pounds, I can only wonder upon what foundations these stories and these enormous prices are based.

Up to its present stage of development, British East Africa is essentially an agricultural and pastoral country. Although extensive prospecting has been carried out, no mineral wealth of any value has been discovered, nor does the geological formation of the country hold out great hopes of any such discovery in the future. So far there is no sign of any large exporting or manufacturing industry, which will supply a sufficiently large population to permit of a local market for agricultural and pastoral produce on a large scale. From the farmer's point of view, export is difficult both on account of the distance of his markets, and the high freightage rates on the railway before cver his produce is on board ship. The country is further handicapped by the absence of any large watcrways by which an extensive lumber trade could be handled and railway freightage for other commodities avoided. 
It is, I believe, an accepted fact that, although the small farmer and tiller of the soil is, under certain circumstances, the backbone of a nation, yet no purely agricultural and pastoral community ever has or ever can attain to great wealth. Such being the case, it is difficult to see wherein at present lies the justification for the enormously inflated landvalues in British East Africa. Land that a few years ago was obtainable at one shilling and fourpence an acre is now selling for one hundred pounds per acre, while thirty shillings per acre is, I am informed, the average price of grazing land. This seems to me, under present conditions, absurd.

Not the least of the difficulties under which East Africa suffers is the labour question. Like his white brother, the African native is in bulk averse to work. Laziness is, indeed, one of the primary instincts of the human race, and I question-notwithstanding all the talk of "the dignity of labour" and all the rest of it-whether one per cent. of us enjoys work-manual and physical labour, at all events-and whether an equal percentage would do any work at all if not driven thereto by stern necessity. The black man is, however, more fortunately situated than the average European. A very short spell of labour puts him into the possession of suffi- 
cient means to ensure him a life of ease for the remainder of his days. A plot of land is his for the asking, on which a small amount of labour suffices to build a hut. His earnings provide the purchase-money for a couple of wives, and possibly a certain amount of livestock. His wives till the ground, the fertility of which ensures him crops sufficient for the daily needs of himself and his family. What need, then, to work after sufficient earnings have been amassed to provide a life of comfortable ease?

The European, with sufficient savings, retires from active life in a precisely similar manner, but the negro's retiring point arrives considerably earlier in his career than does the white man's. We cannot in fairness blame the negro: his logic is precisely similar to our own; but, since his working career is so short a one, it follows that in countries dependent upon black labour, such labour is going to be pretty hard to get. Increase of wages-the remedy of civilization-only intensifies the difficulty, since it accelerates the labourer's retirement from activity. If, on the other hand, you cut down rates of pay to a fine point, your native argues that he can do better working on his own land, and so you lose him again.

Logically, the only remedy would seem to 
be some form of forced labour, but any such system infringes dangerously upon certain accepted doctrines of the British Constitution. Logically, I repeat, this seems to be the only policy, and, since practically all labour in the world is forced (though in most cases the driver is the grim spectre, starvation-a harder taskmaster than any Government ordinance) it may be assumed that every community has the right to enforce a certain quantity of labour upon each and all of its units. Abstract logic and practical governance, however, are widely separated poles. Meanwhile, in East Africa (as elsewhere) the labour question is acute.

So far, most of the money made in British East Africa and Uganda has been derived, directly and indirectly, from the "safari" business. Mercantile firms, agencies, stores," hotels, etc., have reaped and are still reaping a rich harvest from the tourist, mainly the tourist in search of big game. There is undoubtedly much money to be made in catering for what, in my humble opinion, is the greatest asset East Africa possesses, and which, up to the present, has been the principal cause of her rapid progress.

East Africa differs from almost every colony in that it has had almost from its earliest days a considerable population of wealthy individuals, drawn thither by the magnet of big 
game shooting. Of these wealthy individuals no inconsiderable numbers, fascinated by the indescribable attraction of the country, and possibly regarding property there in the light of a good speculation also, have acquired real estate, mainly in the highlands, and have resided for varying periods of time upon their African estates. Wealthy men have arrived from South Africa and have taken up their abode in Equatoria. As a result money has been comparatively plentiful. From the golden stream of wealth, plentiful rills of money flowed, with the consequence that there always has been, and, I presume, for some time will be, a considerable sum of money in circulation in the country. That the major part of this money does not stay in the country, but eventually finds its way to India, via the countless Indian merchants and traders, great and small, who have descended upon East Africa, is, for the moment, beside the point. The money has been, and still is, in evidence and has given rise to a fictitious appearance of prosperity which did not in fact exist. How long the wealthy man will pervade the country one cannot prophesy-so long as he does some one will make money out of him-as is right and proper. If, or when, from any cause he disappears, it would be a fairly safe bet that we shall hear of no more land-booms 
for some considerable time. Hence one can safely say that big game has been and is one of the greatest-if not the greatest-assets of the young colony.

East Africa differs also from the majority of colonies in that its earlier exploitation and opening up, after the days of the East African Company was practically entirely the work of Government officials. There was none of the gradual development and opening up at the hands of the small pioneering farmer, who forced his livelihood from the country he exploited, so that as the country opened its opening was accompanied automatically by a population of small landholders. In East Africa there was none of this. The country was pioneered by Government servants far more than by the typical pioneer of-saythe Western States of America, and so it came to pass that Equatoria's early white population consisted of the civil official, the military officer, the missionary, and an occasional trader. Each of these had his own sphere, clearly and distinctively marked, and the coming of a new and unfamiliar type, civilization's advance guard, the man of the frontiers and the mining camps, from the far West or the Australian back-blocks, brought little less than consternation to a certain class of official mind. 
It is true that some of the newcomers were undesirables of a bad type. At the end of the Boer War South Africa cast forth desperadoes and deadbeats of the worst sort, who had all to gain and nothing to lose in the opening up of a new country. What wonder that friction occurred?-the marvel is that it was not more serious. In itself it was nothing, but the evil arose in the birth of a tradition of conventional hostility between settler and official. This grew and extended, affecting the later arrivals, good and desirable men, since from the moment of landing there was poured into their ears the tale of official lack of sympathy, repression, hindrance, and resentment at encroachments on what they (the officials) appeared to consider their private property. Amongst the officials, too, the tradition grew stronger-as indeed it could hardly help doing-till at last there was dangerous bitterness on both sides, which was unfortunately intensified by the coming of a weak Governor, disliked and distrusted alike by officials and non-officials.

Enough has been said to show that the early settlement of East Africa was not without its difficulties. Fortunately things have changed for the better under the late Governor, Sir. Percy Girouard. Taken all round the East African official is a first- 
class man, working hard on his none too munificent pay, and trying to the best of his ability to do the job for which he draws it. The settler also is a good man, working no less hard to live his life and make a home for himself and his family. Each side has discovered that the other fellow isn't nearly so bad as he once appeared to be, and both parties are working together for the development of the young Protectorate.

So much for generalities : let us now take a more detailed, though necessarily brief, survey of the two belts of country mentioned in the early part of this chapter. I do not propose to quote trade statistics and returns, total yearly values of imports and exports, and the like, but merely to touch broadly upon certain trades and industries, and to indicate shortly the particular lines upon which the promise of the future appears to lie.

Commencing with the tropical belts, we find extreme fertility coupled with generally more favourable labour conditions, and, in the case of the coast-belt, comparatively easy access to transport for exportation. The main industries of these zones are rubber, cotton, groundnuts, coco-nut products, sisal and ramie fibre, all of which hold out prospects of success in helping to build up a large 
export trade. These low-lying zones are by no means health resorts, and it is essential for a European residing there to make periodical trips to Europe on the grounds of health.

Apart from climatic questions, my firm opinion is that the future wealth of the Protectorate depends far more upon the cultivation and export of such products as flourish in the tropical belts than upon the produce of the uplands. Though handicapped by distance from markets, by Suez Canal dues, and various minor drawbacks, I can see no reason why a large export trade in tropical produce should not be built up. But for any enterprise here, as well as in the highlands, the possession of capital is a sine qua non. Given capital, an inclination for a long residence in the tropics, and the ability to work hard, there are many worse places to find a livelihood in than the tropical zones of British Equatoria.

As regards the tropic belts not on the coast, they have the disadvantage of considerable distance from the port of lading, but this disadvantage is somewhat counterbalanced by the fact that land and labour are cheaper and easier to obtain. Should, as has been suggested, a light railway ever be constructed along the valley of the White 


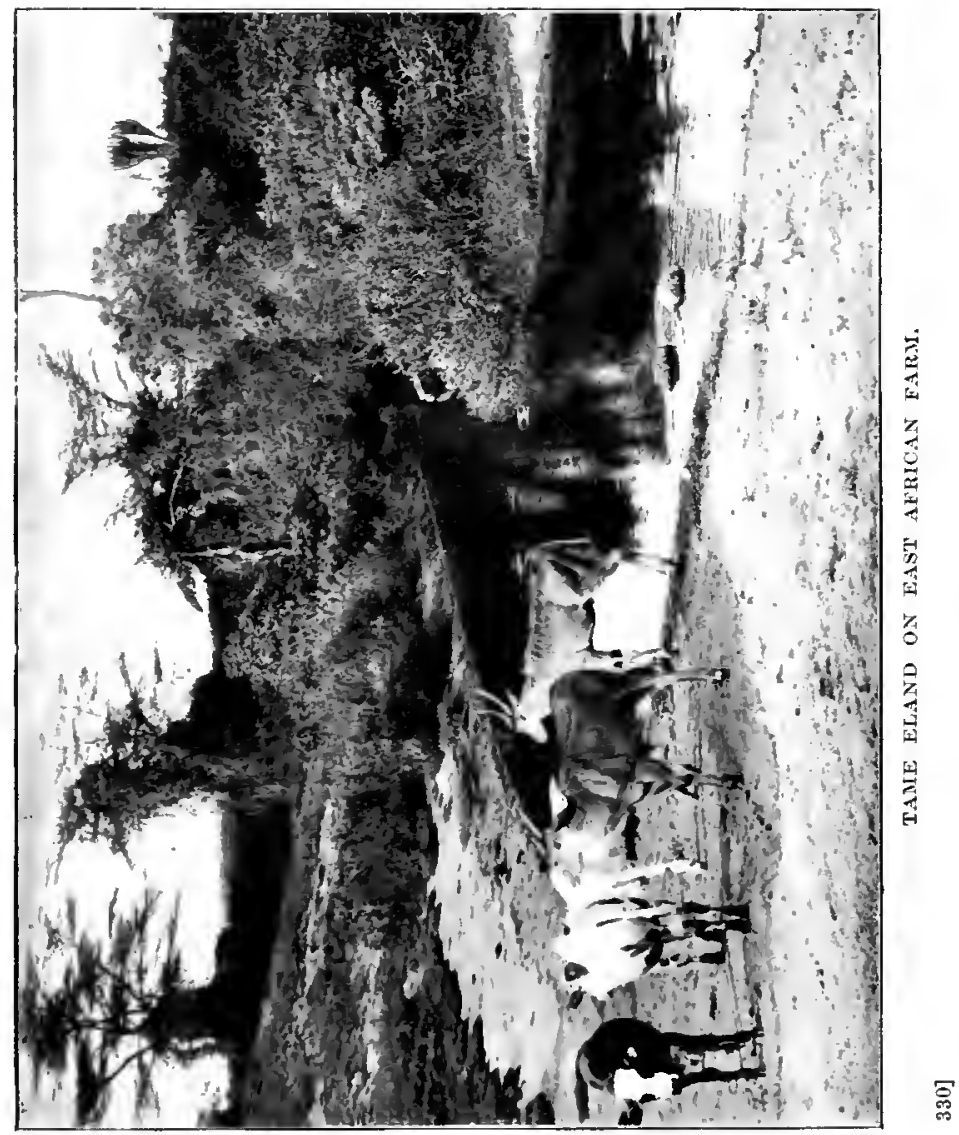



Nile as far as Gondokoro, the shipment of produce from the northern portion of Uganda to the Mediterranean by river and rail would be a comparatively easy and inexpensive process. That day, however, is not yet.

As regards the highlands of British East Africa, I have already discoursed extensively upon them with regard to their suitability for white colonization. The plateau is an admirable country for agriculture and stockraising. It is generally extremely fertile, the rainfall is regular and to be depended on, and double crops are the rule. Cereals do well, certain timbers, such as black wattle, ensure a quick return, coffee so far has had excellent results, and sisal hemp equally so. These last two seem to promise the foundation of an export trade, while potatoes of excellent quality are being exported to South Africa. Apart from these articles the local agriculturists are dependent upon local markets for the disposal of their produce, and, as I have tried to show, local markets on a large scale are non-existent as yet.

The stock-raiser, I think, stands in a better position from the money-making point of view, in that he has a greater local market for his produce. Dairy-farming has in the past paid well, and there is always a demand, amongst the native population and the Indian 
and Somali traders, for cattle. Meat also is always in demand amongst the natives. Hides are also a marketable commodity, while the sheep-farmer should be able to compete with Australia in the wool-markets of the world. The introduction of English stock has improved and is improving out of all knowledge both cattle and sheep. Unfortunately, owing to burrs, etc., not all the pasturage is suitable for wool-producing sheep, but nevertheless there seem to be good grounds for anticipating a satisfactory future for the wool-exporter. There also seems to be no good reason why a cold-storage business should not prove successful.

As regards local industries and manufactures, I have always been of opinion that two at least would immediately on inception tap a very large local market. The first of these is a cotton-ginning and spinning establishment to handle the locally grown cotton, and to supply the enormous native demand for cheap cotton goods. The second is a tannery and leather-goods manufactory. There is already a large export trade in hides, which could be handled locally, and the country produces bark suitable for tanning purposes, while the demand-white and black -for boots, shoes, saddlery, harness, and a thousand and one leather articles, is large 
and increasing. In addition to the local market, I am of opinion that these two industries could command a considerable export trade. Of course there are other industries which could be and doubtless will be developed, but these two have always been hobbies of mine.

Ostrich-farming is another lucrative industry of the highlands, and I believe that pig-breeding on a large scale is now in progress.

So much for a brief outline of some of the main industries of the temperate and tropical zones. In so small a space it is, of course, only possible to indicate in the briefest possible manner the lines upon which industrial concentration might prove profitable. It remains now only to tender a few remarks upon trade in general in Eastern Africa.

East Africa is, as I have said, handicapped by its geographical position and features in the commercial competition of the world. When I was in the country a further handicap from the British point of view was the fact that the major part of the carrying trade and of the handling in bulk of imports and exports had passed from British to German hands. So much has been said and written on this subject, its causes, and the blame for such a condition, that it need not be laboured here. 
Suffice to say that such a condition did, and I believe still does, obtain in East Africa, and in my humble opinion the British merchant has no one to thank but himself for this state of affairs. His attitude of "Take what I bring you or do without it" contrasts unfavourably with the German's "Tell me what you want, and I'll get it for you."

One is frequently asked what are the chances for a youngster, well educated, hardy, and not afraid of hard work, going out to British East Africa "on spec." To this question I would answer, "Nil." The demand for white labour is small, and to take up land and make a living without capital is impossible. The question then arises, How much capital is necessary? The amount must of course vary, and depend upon what one has in one's mind's eye-what part of Equatoria one is making for, and what one is going to do when one gets there. Personally I should be sorry to start life in British Equatoria with less than two thousand pounds behind me, and a small annual income in addition to ensure a reasonably comfortable existence during the first lean years.

I can imagine nothing more fascinating than a farm life on the East African uplands. Under such conditions I would settle there to-morrow, with the confidence that in time I 
should be able to earn a decent competence from my land, with the ever-present possibility (not probability, be it noted) of some at present unforeseen development bringing in a fortune. Without outside resources an African farm is about the last place I should select. Under present conditions no big fortunes are to be made there in farming. Without capital I doubt if existence is possible. With capital one may live and make an income off one's farm, but "big money" is not to be made. True it is that certain individuals have done well out of land, but they obtained their land in the days when far less capital was requisite, and their modus operandi has been in the main the old, old commercial one of buying cheap and selling dear. This policy has been rendered easy by the periodical influxes of comparatively wealthy men, eager to obtain land in the newly opened up country. There must, however, I firmly believe, be a reaction, when land will revert to its normal and proper value. Fortunately most of the big buyers are sufficiently well off to stand the racket. A few years ago, when land could be bought cheap, there was money in this: now that happy time is over-at any rate for the present.

Had I a certain amount of capital-say two thousand pounds-but no annual income, I should, were I deciding to settle in Equatoria- 
regretfully enough-turn my back on the highlands, fascinating as they are, and make for the coast-belt or Uganda, where half-a-dozen commodities present far greater money-making potentialities than any agricultural or pastoral pursuits in the more healthy parts of the country. But everywhere, and for everything, capital is essential.

I know that I am controverting the views and opinions of a number of men who have greater and more recent knowledge of East Africa. One can, however, but state one's opinions (which are opinions merely) and the reasons upon which they are based: in this case a close following of the literature relating to East Africa, and conversations with men of all classes-commercial, official, etc.-now residing in the country, together with my own personal knowledge of the state of things obtaining there before I left.

I sincerely hope that-in so far as my views are pessimistic-I may be wrong, and that the rosy optimism which is so much en évidence is entirely justified. The early settlers and pioneers, in particular the small landholders, of a new country deserve (though they frequently don't get) all possible prosperity, and the East African settlers as much as any. Since the hostility between settlers and Government officials, as a class, in which neither side 
was free from faults-since that hostility has been scotched, the progress of the young colony, for reasons which $I$ have endeavoured to indicate, has been surprisingly rapid. That its forward progress may continue is my earnest hope, and, with development along correctand conservative-lines I believe that it inevitably will do so. What precisely the future will hold no one can say. That East Africa will be "the coming country," "the country that beats Canada," I myself do not believe -at any rate not in our time; but $I$ do believe that if it will consent to go slowly, to walk before it tries to run, to guard against outgrowing its strength, it has before it a future of quiet prosperity, capable of great but gradual extension, the unknown possibilities that Africa contains looming always in the background.

There is, however, one problem which will have to be solved in the near future, and to which I have alluded briefly in the earlier part of this chapter. The problem is that of the British Indian. The Indian has descended in very large numbers upon British East Africa, where he finds employment in a considerable number of ways. There are very rich firms of Indian contractors and merchants, and Indians figure in a descending scale thence, and appear as traders, agriculturists, shopkeepers, 
clerks, Government employees, domestic servants, etc., etc. Local opinion strongly condemns their presence. Their effect upon the African natives is bad in the extreme from a moral and from other points of view. A very large amount of the trade of the country passes through their hands, especially the business of the petty trader, and consequently they absorb a very considerable amount of the money in circulation, more especially since they do an enormous amount of money-lending at exorbitant rates of interest. If this money remained and circulated in the country, matters -viewed from the standpoint of political economy-would not be so bad, but some 99 per cent. of it finds its way to India. The Indian community may therefore not inaptly be compared to a leech sucking the life-blood of the Protectorate. I personally consider their presence an almost unmixed evil, and so I fancy do the majority of white men in the country.

The authorities, however, whatever their opinion of the matter may be, are, whether they take action or remain passive, liable to find themselves impaled upon the horns of a dilemma. If the Indians are permitted to remain and batten upon the country, they do the country actual harm, and arouse grave discontent among the white population. On 
the other hand, the Indians are British subjects, and to deny a British subject the right of habitation in a British colony is unconstitutionalism of the grossest kind; moreover, so great is the number of the Indian community, and so firmly are they established, that any movement to dislodge them would raise a veritable hornets' nest about the ears of the Indian Government, and to a very great extent about the ears of the British Government.

The problem is an extremely knotty one, and any satisfactory solution seems almost impossible to find. Let us, however, hope that a solution will in the near future be evolved, since in the opinion of a large number of experienced persons the presence of the Indian community is likely to prove one of the most formidable obstacles to the progress of the country, and to the future of prosperity to which it may reasonably and legitimately look forward.

In a short space of time East Africa has advanced and progressed marvellously. If it be content to take for its motto "Festina lente," and to permit its expansion to proceed along orthodox and conscrvative lines, to avoid a speculative and over eager policy, to refrain from straining and striving to get to the front with undue speed in the mad rush of this hurrying century, all will be well. But 
if, carried away by artificial and largely ficti-tious signs of prosperity, it goes beyond its depth, overstraining strength and credit, the inevitable resultant collapse will put back by years the future prosperity which it is justly entitled to anticipate. 


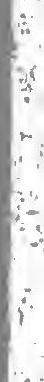

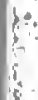

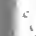

$\mathrm{i}$

i.

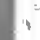




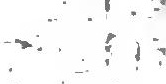

$x+4$
17
4

is

is 


\section{N D E X}

Adan, Mahomed, the Somali gun-bearer, 208 ; present at a buffalo drive, 117 ; attacked and wounded, 119-122

Affudu village, 185

Africa, British and German East, delimitation of the boundary, 87, 91

Ainsworth, John, Sub-Commissioner of Nairobi, 17

Albert, Lake, 40

Albert Edward, Lake, 48

Anglo-German Boundary Commission, $81,87,89$; members, 90 ; method of work, 91-94; survey parties, 92 ; the theo. dolite survey, 92 ; relations between, 94,129 ; system of administration, 94 ; supply of food, 95,198 ; establishment of depots, 96; means of transport, 97, 199

Angoni tribe, 252

Animals, number of, 13 ; characteristics, 14 ; shooting, 09101 ; treatment of wounded, 218

Ant, the white, voracity of, 58 Antelopes, a herd of roan, 102

Arabcherson, robs a Swahili trader, 167-170

$\Delta$ ragoboliage, chief, 27 ; expedition against, $27-30$

Arrows, poisoned, 65

Assouan, 45

Athman wad Musa, 161

Athmani, 156, 171
Baganda tribe, 251, 276

"Baggara," size of, 225

Bahr-el-Abiad, 45

Bahr-el-Arzek, 45

Bahr-el-Jebel, 45

"Banda" or shed, 54, 156

Bantu tribe, 282

Bari tribe, 278, 279

Benin River, 83

Black-water fever, attack of, 65

Blackburnc, Dr., 75

Blood-drinking, method of obtaining from cattle, 271

Boer War, result of the, 328

"Boma," or Government enclosure, form of, 158

Bombay, 1

British East Africa, Boundary Commission, 89 (see Anglo. German); races, 276-283 ; three zones or belts, 314 ; climate, 314 ; views on the suitability for European colonization, 316, 331 ; climate of the highlands, 316 ; power of the sun, 316 ; diseases, 317 ; risk of working hard, 318; precautions against illness, 318-320 ; value of land, 321323,335 ; agricultural and pastoral country, 322 ; difficulty of export, 322 ; labour question, 323-325; the " $\mathrm{sa-}$ fari" business, 325 ; exploitation the work of Government officials, 327 ; industries of the tropical beits, 329 ; neod 
for capital, $330,334-336$; fertility of the highlands, 331 ; crops, 331 ; dairy - farming, 331 ; sheep - farming, 332 ; proposed industries, 332 ; trade, 333; problem of the British Indians, 337-339

Buffalo, a herd of, 111, 200; mole of hunting, 112, 122; pursuit of a wounded, 114 ; a drive, 115-123; result, 125 ; strength and impetus of a charging, 125

Buhima tribe, 276

Bullets, soft-nosed, use of, in shooting game, 154

Bunyoro tribe, 276

Buret tribe, 278, 279, 280

Busoga tribe, 276

Butiaba, 35, 40

Bwana bin Bukoba, 160

Cannibalism of the Wanyema tribe, 247-249

Chaka, the exploits of, 265

Cheriko, 167, 169

Chevallier, Dr., 109

Christianity, compared with the creed of Islam, 302 ; oomplex character of the faith, 304,306 ; character of the average native Christian, 307 , 310 ; work of the missionaries, 307

Churchill, Rt. Hon. Winston, M.P., liis shooting-trips in East Africa, 151

Collector and magistrate, duties of, 163-165

Congo Free State, 183, 294

Congo Pigmy type, 282

Connaught, Duke of, hisshootingtrips in East Africa, 151

Cotton, Major Powell, 43

Cotton-ginning and spinning manufactory, 332

Crocodiles or "Mamba," 50, 61 ; number of, 291

Dairy-farming, 331
Decle, Lionel, 248

Dentist, visit to a, 32

Dickinson, Capt., 112 ; at a buffalo drive, 115-122 ; number killed and wounded, 124 ; at the Guaso Nyoro River, 198; "Big Game Shooting on the Equator," 213

Dinkas, the, 254

Dorobo tribe, 279 ; their dialect, 279

Dufile, 45,183

Education, need of, for the pagan, 308, 311

EI Donyo Erok, food depot, 96

Eland, shooting an, 202

Eldama Ravine Station, 140, 270

Elephants, a herd of, 34, 37 ; shooting, 36-40, 189 ; track. ing, 185-189; tracking a wounded, 190-197; escapes from, 292, 293

Elgeyo, 278, 279, 280

Elgon, Mount, 278, 279, 280

"Elmoran" or warriors, 20 ; their mode of life, 266 ; food, 267 ; dress, 267

Entebbe, 33, 60, 243

Fajao, 41

Fashoda, 45

Fishing, 225

Food, shortage of, 85

Fort Martin, 160, 167, 169

Fort Ternan, 18, 26, 32 ; arrival at, 22 ; buildings, 24

Galla tribe, 275

Gama, Vasco da, 7, 299

Game, shooting, the ethics of, 148-152; the unwritten law, 214 ; rules, 219 ; list of localities, 221 ; stalking, 149,213 ; riding down, 215 ; use of a mâchan, 215 ; tho "gamehog," 219

Gaveta, 264

Gazella Robertsi, 85

German East Africa Bonndary 
Commission, 87, 89; members, 90 ; method of surveying, $92-$ 94 ; system of administration, 94; conflicts with the Masai, 263

\section{Giraffes, 15}

Gironard, Sir Peroy, Governor of East Africa, 328

Gondokoro, 33, 45

Gorges, Colonel E. H., 26

Gnaso Nyiro Camp, shooting, 111,221 ; game-reserve, 127

Guaso Nyiro River, 80, 81, 83, $84,85,87,110,198,235$; food depot, 96

Guinea worm, method of treatment, 57

Gun-bearers, the use of, 217

Hall, Capt. C. R., xv

"Hallol," meaning of the word, 107 note, 178

Hamilton, Major Stevenson, " Animal Life in Africa," 223

Hamis bin Bokhari, case of, 162

Hamman's Kraal, 42

Hayes-Sadler, Sir James, Governor, 61 ; his punitive measures against the Nandi, 139

Hippopotami, number of, at Jinja, 61

Hobley, Mr., on the date of the Nandi migration, 280

Hoima, 35

Hollis, Mr., on the Nandi tribe, 278-281

Honcy, a meal of, 206

"Hongo," or tribute, custom of exacting, 262

Hope, Mr., Political Officer, 78, 80

Horse-sickness, 225

House, an African, style of, 23

Impala, a herd of, 180

Indian boy, his adventure with a lion, 286

Indian, the British, problem of, in East Africa, 337-339

Islam, the faith of, 299, 300; compared with Christianity, 302 ; characteristics, 303 ; the Koran, 304 ; simpliaity of the faith, 304, 310

Jackson, Mr., Governor of Uganda, 153; "Big Game Shooting," 213

James Martin, sailing-boat, 36, 40,46

Jiggers or burrowing fleas, 55,56 Jinja, 60 ; ravages from sleeping sickness, 63 ; fishing, 225

Johnston, Sir Harry, "Uganda Protectorate," 276; on the date of the Nandi migration, 280 ; his view of the MasaiNandi group, 282

Juma Masudi, Private, case of, 160

Kabwaren, 75

Kaimosi, American Quaker mission at, 75

Kamasia, 280 ; tribe, 278, 279

Kapsumu, massacre Swahili, 68 ; expedition against, $68-73$

Karamoja, 282

Karungu, food-depot, 96, 97

Kavirondo, 26, 278 ; tribe, 251, 282 ; their characteristics, 251 , 283

Kedong River, 81, 82

Kenia, Mount, 276

Kericho, 26, 30, 222

Khartum, 45

Kibaibai camp, 109

Kibigori, 139, 222

Kibos, 132

Kilimanjaro, Mount, 12, 91, 129, $171,181,239,241,289$

Kilindini, I1

Kisabi River, 83, 84

Kitchener, Lord, purchases an estate at Mohoroni, 132

Kiu Station, 96

Kony tribe, 279

Koran, the, 304

Labour question, 323-325 
"Laibon" or chief medicine man of the Lumbwa tribe, 27 ; of the Nandi tribe, 139 ; his death, 139

Laikipia, 273

Laitokitok, 129

Land, valuo of, in Britisl East Africa, 321-323, 335

Lanjoro Diss spring, 128

Latuka tribe, 282; their lan. guage, 261

"Leguynan," or captain, 267

Lenana, appointed chief of the Masai, 263

Leopard, markings of a, 209

Lion, first sight, 16 ; shooting, $104-106,202-205$; the roar, 210 ; watching at night, 208212 ; adventures with, 286289

Loita Masai tribe, expedition against, 78, 80, 87

Lubwa's Fort, 42

Lugard, Sir Frederick, his adminiatration of Uganda, 252

Lumbwa, 103, 132, 139 ; tribe, $22,26,276,278$

Illxor, 45

"I.yoni," or boys, 266

Mâchans, use of, in killing game, $115,208,215$

Magadi, Lakc, 81, 128

Mahagi, 41

Mahomed, the teaching of, 303, 310

Makupa, 11

"Mamba," or crocodile, 50

Mara River Camp, 90, 96, 97 ; position, 08 ; climate, 100 ; a day'a shooting at, 10I-108

Marabou storks, 98, 103

"Marissa," effects of, 77

Masai tribe, 18; their characteristios, 252, 274; thcories of thoir origin, 260 ; languago, 261; sub-sections, 261, 269271 ; a pastoral race, 261 ; the chief Mbatien, 262; custom of cxacting "liongo,"
262 ; raiding-parties, 264 ; military system, 264; the scourge of Africa, 265; military operations, 265 ; social system, 266-268 ; the "lyoni," 266 ; "ndito," 266 ; "el. moran," 266 ; "leguyan," 267 ; food, 271 ; method of obtaining blood for drinking, 271 ; courage in lion-hunting, 271 ; method of fighting, 272; religious belief, 272 ; customs and superstitions, 273 ; removal to Laikipia, 273; measures for the preservation of the race, 274

Masud wad Ibraham, ColourSergeant, 68

Mau foothills, 82, 222 ; Plateau, 25

Mayes, W., collector of Nandi Fort, 05

Mbatien, the ohief or "laibon" of the Masai, 262; his prophetic utterances, 262

Mbombo, chief, 255

Merker, Capt., his theory on the origin of the Masai, 260

Missionaries, the work of, 307 ; various types, 308

Mnyema, Simba, Colour-Sergeant, $157,159,240$

Mohoroni, 25, 132, 138

Mombasa, or Mvita, meaning of the word, 6 ; use of trolleys, 8 ; climate, 8 ; popnlation, 9 Moshi, 12

Mosquitoes, protection from, 55 ; number of, 173

Mumias, 269

Mursal Said, Sergeant-Major, 68

Mussalman, character of the, 306

Mutei tribe, 279

Nairobi, 16, 75, 89, 129, 321 ; climate, 17, 141; horses, 18, 225 ; races, 142, 227-231; quail and sand-grouse shoot- 
ing, 224 ; polo, 225 ; pig-sticking, 225

Naivasha, 81 ; Lake, 269

Nakuru, journey to, 19-22

Nandi Fort, 63, 75, 139 ; hills, 232 ; tribe, $22,26,130$, 276,278 ; their truculent behaviour, 63, 281 ; punitive measures against, 131, 139141, 143, 281; their character as soldiers, 252 ; country, 278 ; origin, 279 ; appearance, 279 ; allied to various tribes, 279 ; migration, 280,282 ; recent history, 280 ; characteristics, 282

Narangere River, 83

Native, the African, his aversion to work, 323 ; result of his earnings, 324

Natron, Lake, 81, 83, 128, 198

Ndasegara depot, 96, 108, 109

"Ndito" or young girls, 266

Ngong, 81

Ngongo Bagas, 77, 80

Nguruman tribe, 261, 269

Nile, the, $33,244,294$; voyage on the, 44-52; the Bluc, 45 ; the White, 40, 45, 183 ; shooting-ground, 222 ; valley, 261 ; the rainy season, 183 ; tribes, 276,282

Nimule, 33, 183, 185, 196, 222 ; arrival at, 53; houses, 54; insects, 55; climate, 58; mode of obtaining food, 58 ; shooting, 59

Njemps, 269

Nyando River, 26 ; valley, 26, 130,278

Nyangori tribe, 279

Nyika, 129

Omdurman, battle of, 258

"Orderly room," work of the, 160-162

Orys, a herd of, 174 ; stalking, 175-178; shooting, 237

Oryx callotis, 111,127

Ostriches, 15 ; farming, 333
Pagan, the uncivilized, his need for a simple religion, 305 ; education, 308,311

Palitana, s.s., 1

Patterson, Colonel, "The ManEaters of Tsavo," 286

Pig-sticking, 225

Political Officer, use of, 78

Polo, the game of, 225

Port Florence, 18, 89, 221

Races, horse, at Nairobi, 227-231

Recruits, drilling, 157

Rendile, 264 ; tribe, 275

Rhinoceros, mobility of, 16 ; scatter the safari, 110

Rifles, the use of light and heavy in shooting gamc, 152

Rift Valley, 81, 96, 128, 234 ; the Great, 199, 261 ; climate, 199

Ripon Falls, 60, 225, 244

Roan, stalking a, 107

Roberts, Russell, 85

Roman Catholio Cluurch, faith of the, 306

Rooserelt, T., his shootingtrips in East Africa, 151

"Safari " business, result of, 325

Salisbury Bridge, 11

Savages, their mode of fighting with poisoned arrows, 65-74

Schlobach, Hauptmann, Com. missioner, 129

Seloita hills, 83

Sendao, chief of the Masai, 261 ; migrates to German East Africa, 263 ; returns to Britisb territory, 203 ; appointed chief, 264

"Shambas," or gardens, 9

"Shauri," or conference, 25

Sheep-farming, 332

Sherati, port of, 128

Shikar, the ethics of, 213

Shilluks, the, 254

Shomboli, Mount, 128

Shooting game, the ethics of, 148-152; use of light and 
heavy rifles, 152 ; bullets, 154 ; the unwritten law, 214 ; equality between man and beast, 216 ; the use of gunbcarers, 217 ; treatment of a wounded animal, 218 ; the "game-hog," 219 ; rules, 219; list of localities, 221

Shrubsall, Dr., on the Nandi tribe, 279

Sir William Mackinnon steamer, 32

Sirikwa tribe, 280

Sleeping sickness, scourge of, 63

Smith, Capt., British Commissioner, 90

Smithett, 167, 169

Soba, 139

Somali tribe, their characteris. tics, 249-251

Somerset Nile, 33, 41, 60

Sondo River, shooting-ground, 222

Songoro bin Kombo, Private, case of, 161

Sotik, 280 ; tribe, 278, 270

Stalking game, method of, 149 , 213

Stanley, Sir H. M., 299

Stewart, Sir Donald, Governor, 131; his death, 138

Sud, meaning of the word, 46 ; characteristics of the plant, 49

Sudanese, the mutiny, 246, 254 ; first troops introduced into Uganda, 252 ; settlements, 253 ; characteristics, 254-259 ; traditions, 254 ; character of the women, 256 ; morals, 257 ; scnse of honour, 257 ; endurance of pain, 257

Suk tribe, 275, 278

Sussian, 80

Sugwa, Mount, 81, 82

Swahili, attack on, 68 ; trader, robbed, 167-170; their characteristic8, 246 ; language, 275

Tannery and leather-goods manufactory, 332
Taru Desert, 12

Taveta, 129

Thirst, sufferings from, 293

Thompson, John, the first European in Masailand, 202 ; "Through Masailand," 266

Thruston, Arthur Blyford, 42

Tioks, the pest of, 57

Topi, a herd of, 103

Toro, 48

Trolleys, use of, at Mombasa, 8

Tsavo River, 286

Turkana tribe, 275, 278

'Uasin Gishu Plateau, 278, 280; shooting-ground, 222 ; tribe, 261 ; history, 269, 270

Uganda, 294, 316; Boundary Commission, 89 ; first Sudanese troops introduced into, 252 ; settlements of, 253 ; religious creeds, 290 ; the " safari " business, 325 ; railway, $11,19,25$; ravages of lions, 286; telograms, 280

Ujiji, 248

Unyama River, 185

Unyamwezi country, 264

Unyoro, 34

Vandeleur, Seymour, 42

Victoria, Lake, $18,26,60,89$, $128,243,264,276,315$; shooting-ground, 221

Victoria Nile, 41

Victoria Nyanza, 32, 233

Voi, 12, 129

Wa Kavirondo tribe, 276

Wa-Lumeli tribe, 144

Wa-Teita tribe, 275

Wadelai, 33, 42, 222 ; olimate, 43

Wakamba tribe, 275, 277 ; oustoms, 278

Wakikuyu tribe, 275,276 ; their characteristics, 277

Wakwavi tribe, 269

Wanyamwezi tribe, 247 


\section{INDEX}

Wanjema tribe, their characteristics, 247 ; cannibalism, 247249

Ward, Capt, his journoy to Fort Terman, 19-22

Wart-hog, charaoteriatics of, 226

Wildebeeste, herd of, 103 ; shooting a, 179

William Emetic steamer, 33
Wykay stream, 82,83

X., Colonel, stories of, 294-297

Yaos tribe, 252

Young, Mr., xv

Zanzibar, 2 ; first impressions of, 4 ; various races, 5 
PRTNTED BT

HAZEU, WATSOK AXD VEFEY, LD.. LONDON AND ATLEBBURY. 


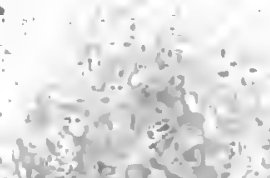

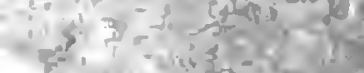

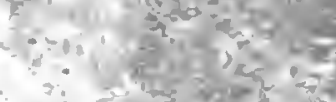

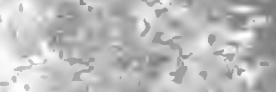

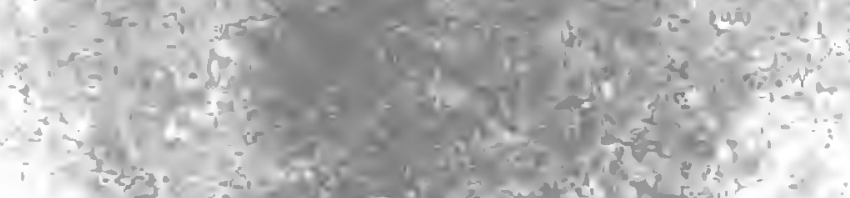

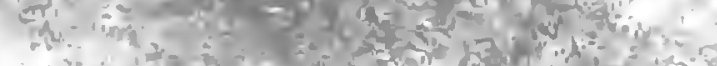

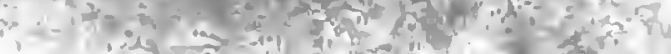




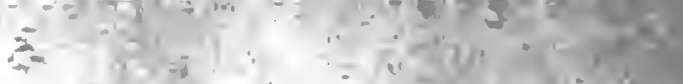

$m=$

$1+i^{2}$
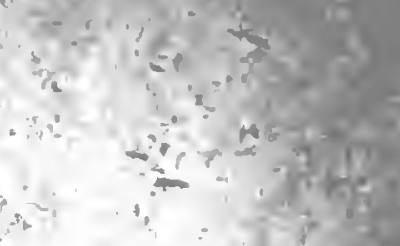

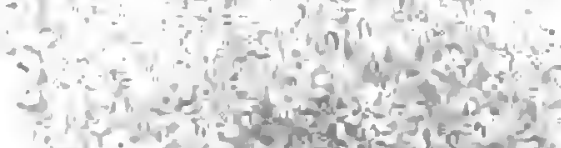

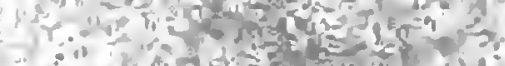

$\because \because ?$ a

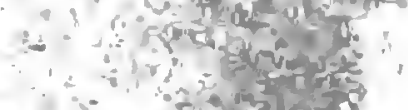

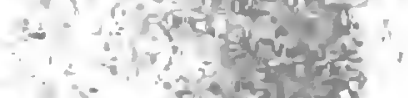

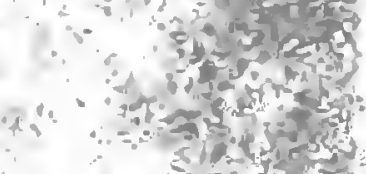

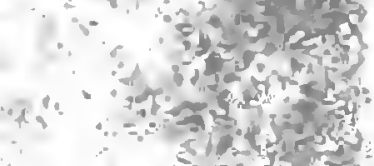
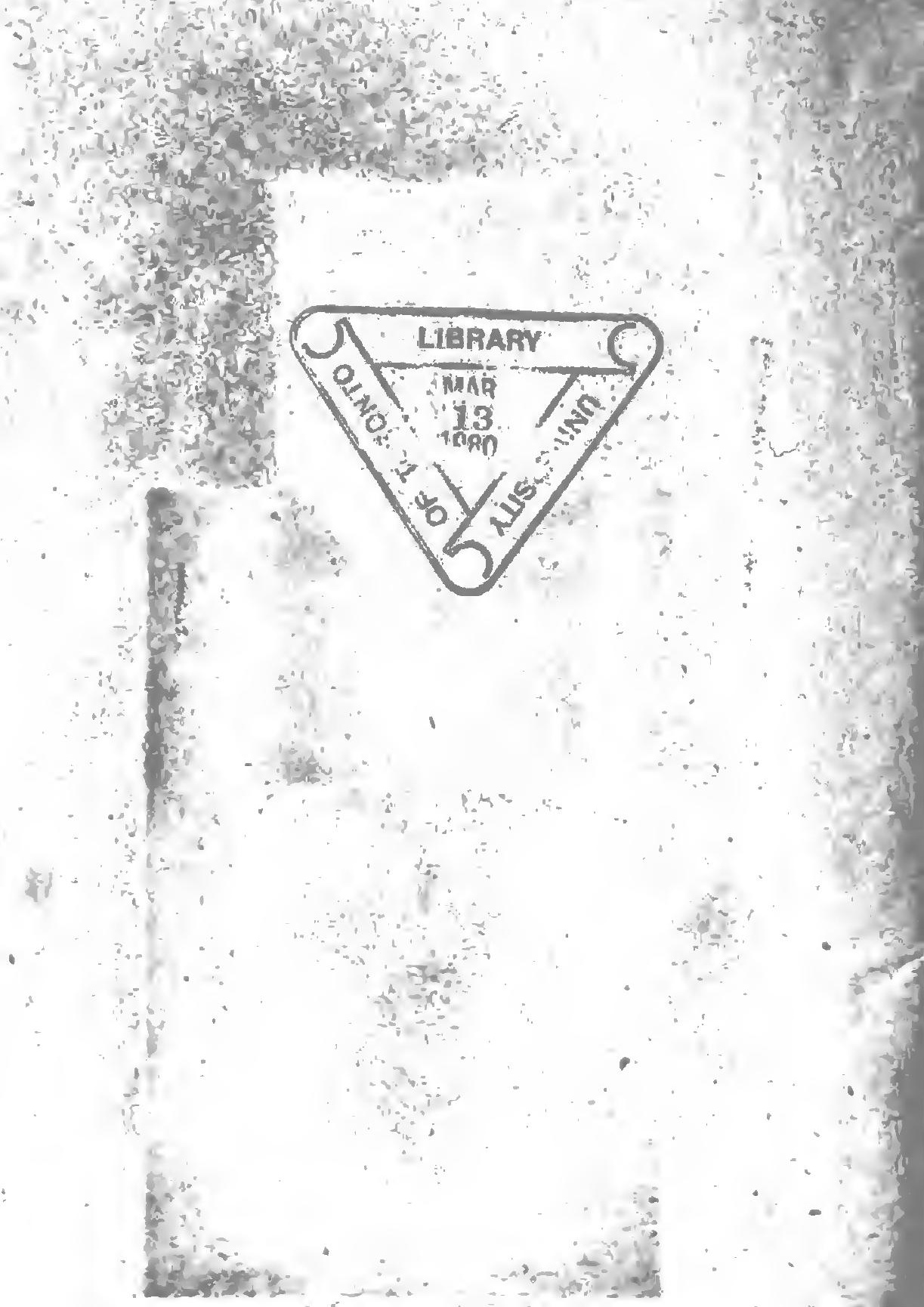

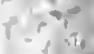

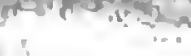

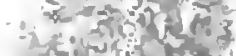

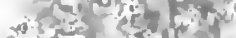

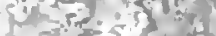

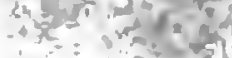

新 


\section{PLEASE DO NOT REMOVE \\ CARDS OR SLIPS FROM THIS POCKET}

\section{UNIVERSITY OF TORONTO LIBRARY}

DT Wilson, Henry Allen

L25 A British borderland

145 
